A Seismic-Stratigraphic Investigation of the Madison and Associated

Aquifers-Application to

Ground-Water Exploration,

Powder River Basin,

Montana-Wyoming

U.S. GEOLOGICAL SURVEY PROFESSIONAL PAPER 1330 


\title{
A Seismic-Stratigraphic Investigation of the Madison and Associated Aquifers-Application to Ground-Water Exploration, Powder River Basin, Montana-Wyoming
}

\author{
A. H. BALCH, Editor
}

U.S. GEOLOGICAL SURVEY PROFESSIONAL PAPER 1330

Vertical seismic profile experiments in conjunction with detailed stratigraphic framework studies suggest that some high-yield water zones in the Madison and associated aquifers may be detectable on surface seismic profiles

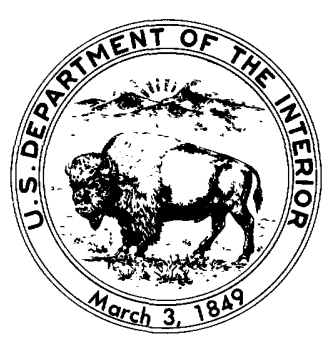




\section{DEPARTMENT OF THE INTERIOR}

DONALD PAUL HODEL, Secretary

\section{U.S. GEOLOGICAL SURVEY}

Dallas L. Peck, Director

\section{Library of Congress Cataloging in Publication Data}

A seismic-stratigraphic investigation of the Madison and associated aquifers-application to ground-water exploration, Powder River Basin, Montana-Wyoming.

(U.S. Geological Survey Professional Paper ; 1330)

Bibliography: $p$

Supt. of Docs. no.: I 19.16:1330

1. Water, Underground-Powder River Basin (Wyo. and Mont.) 2. Aquifers-Powder River Basin (Wyo. and Mont.) 3. Seismic reflection method.

I. Balch, Alfred H. II. Series. III. Title: Madison and associated aquifers.

For sale by the

Books and Open-File Reports Section

U.S. Geological Survey

Federal Center

Box 25425

Denver, CO 80225 


\section{CONTENTS}

[Roman numerals indicate chapters]

I. Introduction to seismic-stratigraphic study of the Madison and associated aquifers, by

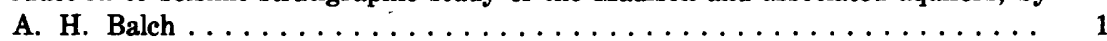

II. Regional stratigraphic framework and genesis of the Madison and associated aquifers,

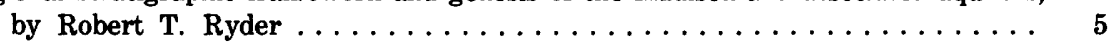

III. Description of the vertical seismic profiling method, by A. H. Balch . . . . . 21

IV. Processing of vertical seismic profile data, by $M$. W. Lee . . . . . . . . . . . 31

V. Acquisition, processing, and interpretation of vertical seismic profiles, by A. H. Balch, M. W. Lee, and Robert T. Ryder . . . . . . . . . . . . . . . 55

VI. Interpretation and conclusions, by A. H. Balch, M. W. Lee, and Robert T. Ryder . 87

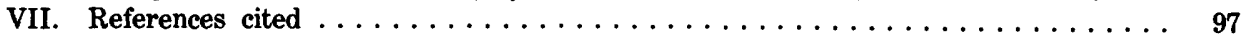



A SEISMIC-STRATIGRAPHIC INVESTIGATION OF THE MADISON AND ASSOCIATED AQUIFERS-APPLICATION TO GROUND-WATER EXPLORATION, POWDER RIVER BASIN, MONTANTA-WYOMING

\section{INTRODUCTION TO SEISMIC-STRATIGRAPHIC STUDY OF THE MADISON AND ASSOCIATED AQUIFERS}

\section{CHAPTER I}

By A. H. BALCH

\section{CONTENTS}

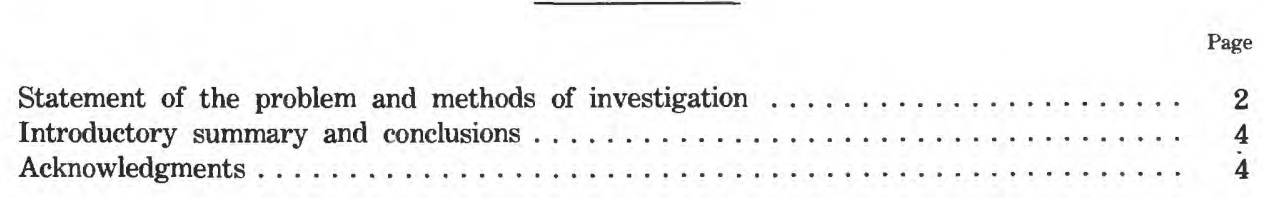

\section{ILLUSTRATION}

Page

Figure I-1. Index map of the Powder River Basin, Wyoming and Montana . . . . . 


\section{STATEMENT OF THE PROBLEM AND METHODS OF INVESTIGATION}

This seismic-stratigraphic investigation is part of a larger 5-year project-the "Madison Project"-undertaken by the Water Resources Division of the U.S. Geological Survey to study the hydrology of the Madison and associated aquifers. The objectives and methods of investigation of the Madison Project are described by the U.S. Geological Survey (1975).

The U.S. Geological Survey (1975) noted that the future development of coal and other energy reserves in the Northern Great Plains will place a heavy demand on the limited water resources of the area. Coal development alone may require as much as 200,000 acrefeet per year. The report also observed that the limited amount of surface water is distributed unevenly-both in time and in space-and no plan to utilize surface water for coal development seems to be tenable. An appropriate investigation, therefore, is that of the water-resource potential of deep carbonate aquifers like those in the Madison Group, Red River Formation, and Pahasapa Limestone.

The production of wells drawing water from the Madison and associated aquifers alone varies enormously. The U.S. Geological Survey (1975) estimated that production ranged from $20 \mathrm{gal} / \mathrm{min}$ (gallons per minute) to $9,000 \mathrm{gal} / \mathrm{min}$. Because the depth of the Madison and associated aquifers in the Powder River Basin commonly ranges from 2,000 to $16,000 \mathrm{ft}$, a necessary part of the investigation is to seek some means of predicting high water productivity from observations made at the surface. One possible means of doing this is by use of the reflection seismograph. The objective of this seismic-stratigraphic investigation is to see if areas of high water productivity in the Madison and associated aquifers can be located by surface seismic measurements in advance of drilling. The term Madison and associated aquifers used in this study incorporates the Madison Group, (primarily the Mission Canyon and Lodgepole Limestones) and the Red River Formation. The term Madison aquifer incorporates just the Madison Group. In the southern Powder River Basin where the Pahasapa Limestone replaces the Madison Group and the Red River Formation is absent, the term Madison aquifer is applicable also.

The seismic detection of porous carbonate rocks also is relevant to oil and gas exploration because many known oil and gas reservoirs are in porous carbonates. Specifically, the Madison Group is a known petroleum reservoir in the Williston basin of North Dakota and Montana, and is being explored actively there. Additionally, several known Madison petroleum reservoirs exist in the Big Horn Basin of Wyoming, the next basin west of the Powder River Basin described in this report.
Because the geologic and hydrologic properties of the Madison and associated aquifers vary significantly over the Powder River Basin, two separate areas were selected for detailed investigation. Additional areas of investigation eventually may be warranted as new well data encounter different sets of geologic conditions and problems. The northern study area is situated in Carter, Custer, and Powder River Counties, Mont., and Crook County, Wyo., on the northeastern flank of the basin (fig. I-1). Both the Madison Group and the Red

\section{EXPLANATION}
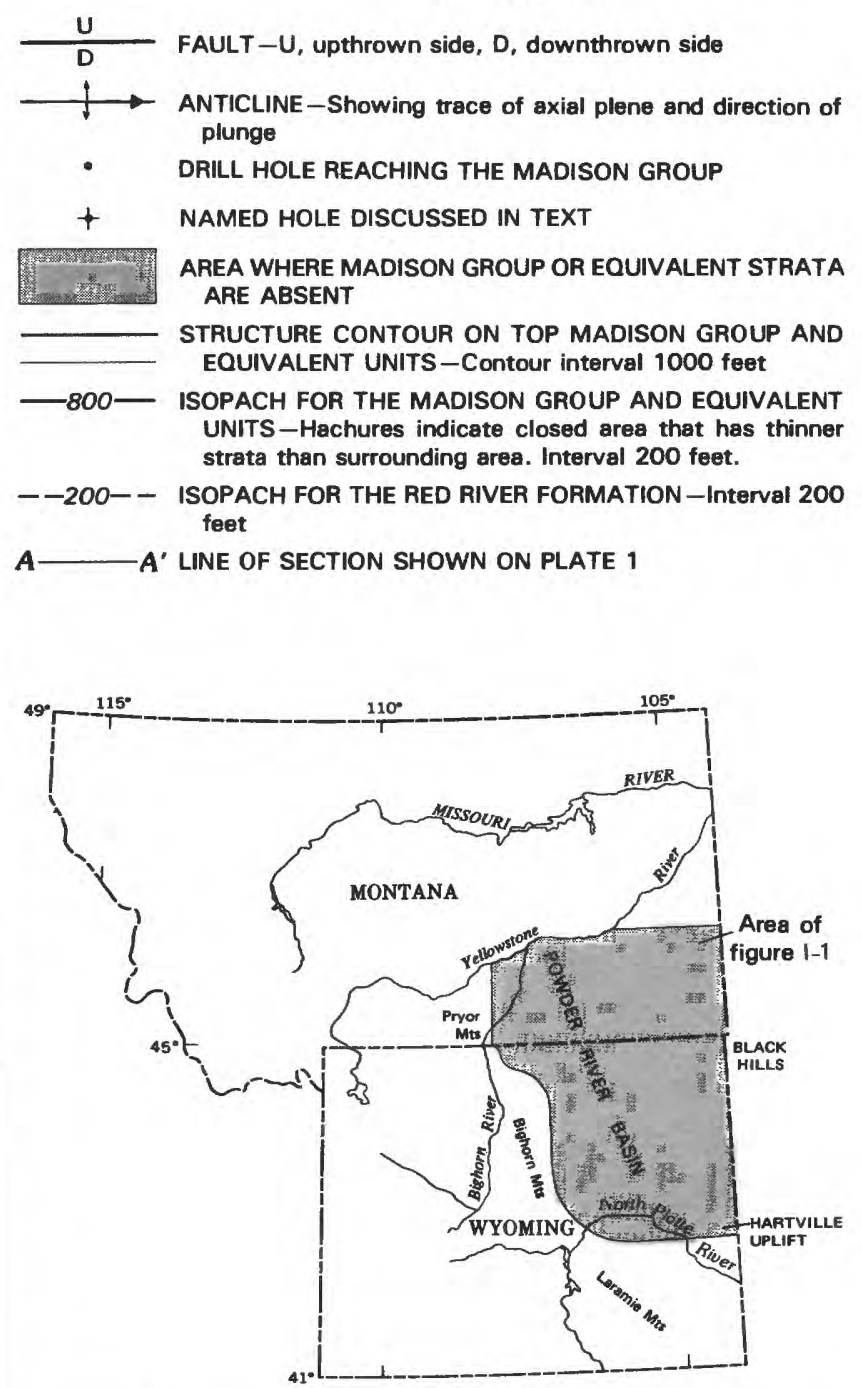

Figure I-1 (above and facing page).-Index map of the Powder River Basin, Wyo. and Mont., showing the location of the northern and southern study areas. Structure contours of the Powder River Basin are drawn on top of the Madison Group and equivalent units. Isopachs for the Madison Group and equivalent units are shown by heavy solid lines. Isopachs for the Red River Formation are shown by dashed lines. All structure contour lines and isopachs are in feet. Dots represent subsurface control points. The location of stratigraphic sections, selected geologic features, and selected drill holes are labeled. Madison structure and thickness are derived from Swenson and others (1976). 


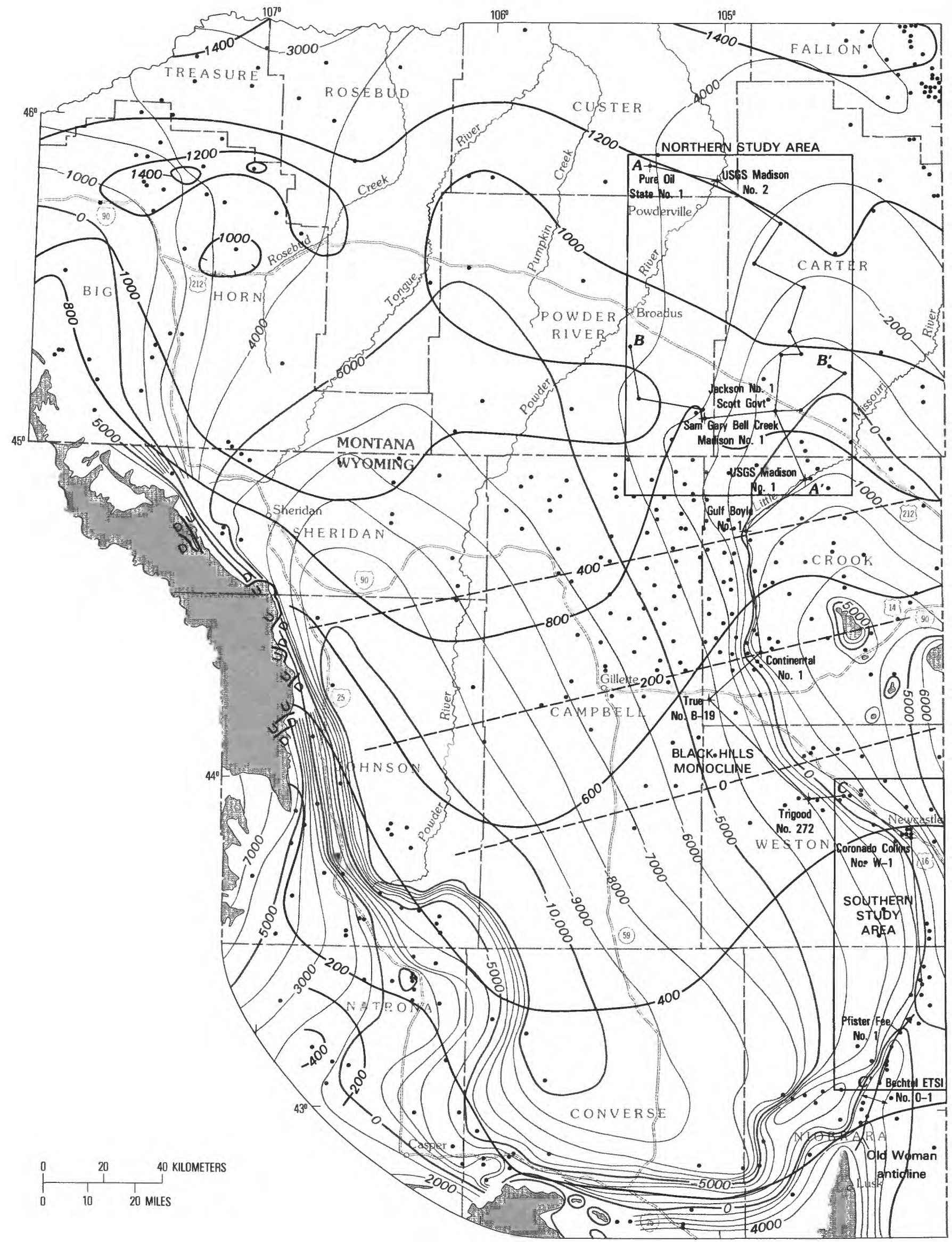


River Formation are relatively thick here and a combined flow rate from them of nearly $1,000 \mathrm{gal} / \mathrm{min}$ has been documented. Flow rates from the Madison and associated aquifers in this region are likely to exceed $1,000 \mathrm{gal} / \mathrm{min}$. The southern study area is about $60 \mathrm{mi}$ south of the northern study area in Weston and Niobrara Counties, Wyo. (fig. I-1). The only representative of the Madison aquifer in this part of the Powder River Basin is the Pahasapa Limestone, a partial equivalent of the Madison Group. Water-flow rates from the Pahasapa Limestone in the southern study area locally attain $1,260 \mathrm{gal} / \mathrm{min}$.

Our procedure has been: (1) to establish the stratigraphic framework of the Madison and associated aquifers and adjacent formations from available subsurface data including well logs, cores, and drill cuttings; (2) to measure the seismic response of the Madison and associated aquifers in a borehole using vertical seismic profiles, both where the aquifers are porous and productive and where they are tight and nonproductive; (3) to determine if any anomaly from surface seismic exploration can be predicted, based on any measured acoustic differences; and (4) to run surface seismic profiles over or near wells for which the water productivity and acoustic properties are known.

On the basis of the material that follows, we believe there are differences in the seismic-acoustic properties of the Madison and associated aquifers that are suggestive of water productivity and that may be detectable with surface seismic profiles.

\section{INTRODUCTORY SUMMARY AND CONGLUSIONS}

In this report we describe how vertical seismic profiles were used to measure certain acoustic properties of the Madison and associated aquifers. We devised new field techniques, new processing procedures, and new methods of interpretation in order to identify acoustic differences between porous-productive and tight-barren end members of the Madison and associated aquifers.

The measured acoustic properties of the Madison and associated aquifers in six wells show the following:

1. A fall-off of high-frequency reflections when the section is productive, relative to nonproductive sections,

2. A substantial increase in the amplitude and number of reflections from the section when it is productive, relative to the nonproductive sections, and

3. That calculated impedance "logs" based on seismic reflections from the interval tend to reveal zones of low impedance that correspond to known zones of productivity.

There remains the question of if and how these differences can be detected from surface seismic-reflection data. This problem is considerably more difficult because the reflections are corrupted by their trip to the surface, the reflections are lower in frequency and narrower in frequency band width due to earth attenuation, and considerable uncertainty exists about the input, or downward-traveling seismic waveform. Nevertheless, the reflections from the Madison and associated aquifers in a surface seismic profile across the Sam Gary Bell Creek Madison No. 1 well where the aquifers are commercially productive differ-in a manner predicted by the vertical seismic profiles-from corresponding reflections in the USGS Madison No. 2 well where the aquifers are nonproductive.

We conclude that the porous-productive and tightnonproductive end members in the Madison and associated aquifers of the northern study area are identifiable on the basis of acoustic differences as observed from reflected wave trains in the exploration seismicfrequency range. The transfer function amplitudes derived from the vertical seismic profiling data suggest that similar results, although more subtle, might be obtainable with surface seismic profiles in the southern study area. However, the absence of a surface seismic profile over a porous-productive Madison aquifer in the southern study area precludes us from providing supporting evidence.

\section{ACKNOWLEDGMENTS}

We are deeply indebted to Elliot Cushing, Richard Blankennagel, Donald Brown, Sam West, and William Head, all of the U.S. Geological Survey, for their technical, administrative, and financial support during this investigation. William Head's contributions are particularly noteworthy. He spent considerable time in the field with the authors and provided technical and logistical assistance to the field operation as well as the support just mentioned.

Messrs. David Cochran, Paul Richardson, and Merle Coke, Birdwell Division, Seismograph Services Corporation, performed yeoman service in the field during the vertical seismic profile acquisition stage.

We thank the management of Coronado Oil Company (John Bollenbacher), Energy Transportation Systems Inc. (Eddie Watt), Gary Operating Company (Fred Haddenhorst, Dave Johnson, Bill Spires), and Murphy Oil Company (D. V. "Pat" Murphy) for the use of the Coronado Collins No. W-1, Bechtel ETSI No. 0-1, Sam Gary Bell Creek Madison No. 1, and Pfister Fee No. 1 wells. 
A SEISMIC-STRATIGRAPHIC INVESTIGATION OF THE MADISON AND ASSOCIATED AQUIFERS-APPLICATION TO GROUND-WATER EXPLORATION, POWDER RIVER BASIN, MONTANA-WYOMING

\title{
REGIONAL STRATIGRAPHIC FRAMEWORK AND GENESIS OF THE MADISON AND ASSOCIATED AQUIFERS
}

\author{
CHAPTER II
}

BY ROBERT T. RYDER

CONTENTS

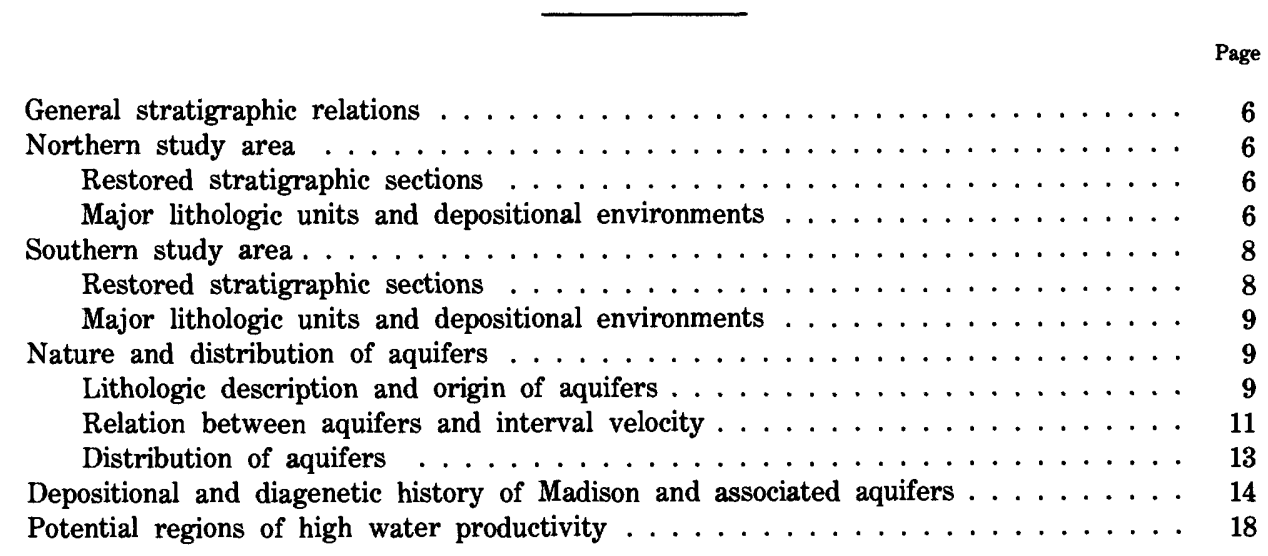

\section{ILLUSTRATIONS}

Plate 1. Restored stratigraphic sections of the Madison Group, Red River Formation, and Pahasapa Limestone . . . . . In pocket

FIGURE II-1. Generalized time-stratigraphic section showing the Madison Group, Pahasapa Limestone, Red River Formation, and adjacent units along the east flank of the Powder River Basin, Wyoming-Montana . . . . . . . . . .

II-2. Plot of interval velocity versus porosity in Madison Group and Red River Formation cores from the USGS Madison

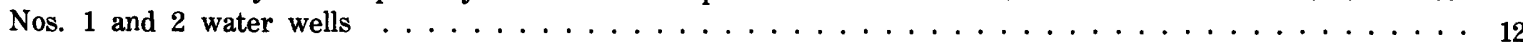

II-3. Depositional and diagenetic model summarizing the formation of the Madison and associated aquifers $\ldots \ldots \ldots$

II-4. Map of the northern and southern areas showing potential trends of high water productivity in the Madison and as-

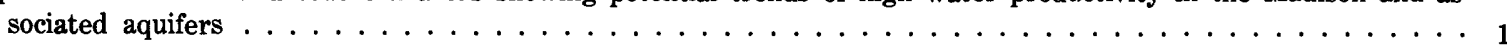




\section{GENERAL STRATIGRAPHIC RELATIONS}

The Madison Group and equivalent strata in the northern and eastern Powder River Basin consist predominantly of shelf carbonate rocks of Early and early Late Mississippian age (Sando, 1975, 1976a; Peterson, 1978). In the northern part of the basin, the Madison Group is subdivided in ascending order into the Lodgepole Limestone (Kinderhookian-early Osagean), Mission Canyon Limestone (middle Osagean-early Meramecian), and Charles Formation (middle Meramecian). Southward along the east flank of the basin, names such as the Guernsey Limestone in the Hartville uplift (Love and others, 1953) and the Pahasapa Limestone in the Black Hills (Gries and Mickelson, 1964) are used locally for strata that are equivalent to at least part of the Lodgepole and the Mission Canyon Limestones (Craig, 1972). To further complicate matters, the Madison Group and its equivalent units in the eastern Powder River Basin conformably overlie a 30 - to 60 -ftthick sequence of dolomite, sandstone, and shale assigned to the Englewood Formation of latest Devonian and earliest Mississippian age (Sandberg and Mapel, 1967). The Englewood Formation commonly is indistinguishable from the overlying Madison Group and Pahasapa Limestone in the subsurface, and thus will be combined with them in this report.

The Madison Group thins gradually southward from a thickness of more than 2,000 ft in the Big Snowy trough-Williston basin depocenter to a thickness of about $200 \mathrm{ft}$ near Lusk, Wyo. (Craig, 1972; Sando, 1976a; Swenson and others, 1976; fig. I-1). Much of the southward thinning was controlled by the intermittent growth of the Transcontinental arch, a positive tectonic element throughout much of Mississippian time (Sando, 1976a). From north to south the Madison Group and its equivalents overlie progressively older rocks that include undifferentiated Devonian rocks, the Silurian Interlake Formation, the Ordovician Stonewall, Stony Mountain, and Red River Formations, and the Cambrian Deadwood Formation (fig. II-1). In the northern Laramie Range, Madison-equivalent rocks rest directly on Precambrian granite (Maughan, 1963).

Differential truncation at the top of the Madison Group also accounts for part of the southward thinning (fig. II-1). This regional unconformity commonly is associated with extensive karstification (Sando, 1974).

The Red River Formation and equivalent Whitewood Dolomite in the Powder River Basin are primarily dolomite units ranging in age from late Middle to early Late Ordovician. The Red River Formation thins gradually southward from a thickness of $460 \mathrm{ft}$ near Broadus, Mont., to a poorly defined, easterly oriented pinchout edge located 15-20 mi north of Newcastle, Wyo. (fig.
I-1). Most of the thinning of the Red River Formation has apparently resulted from pre-Madison truncation (fig. II-1). Near the Wyoming-Montana State line, northward-thickening wedges of rocks of Ordovician, Silurian, and Devonian ages are situated between the Red River Formation and the Madison Group. The Red River Formation conformably overlies the Ordovician Winnipeg Formation consisting of the Roughlock and Icebox Members. These members, as well as some other units such as the Stonewall Formation and the members of the Stony Mountain Formation, have not been formally accepted by the U.S. Geological Survey. However, because they are in common usage in the Powder River Basin, they are used in this report.

\section{NORTHERN STUDY AREA}

\section{RESTORED STRATIGRAPHIC SECTIONS}

Two subsurface sections help define the stratigraphic framework of the Madison and associated aquifers in the northern study area (fig. I-1). The longest section (pl. 1, $A-A^{\prime}$ ) extends northwest-southeast between the Pure Oil State No. $1\left(\mathrm{SW}^{1 / 1} / 4 \mathrm{SE}^{1 / 4} / 4\right.$ sec. 36, T. 2 N., R. 51 E.) and the USGS Madison No. 1 . An east-west section (pl. 1, B- $B^{\prime}$ ) through the Bell Creek oil field and tied with section $A-A^{\prime}$ at the Jackson No. 1 Scott Government ( $\mathrm{NE}^{1 / 4} \mathrm{NE}^{1 / 4} / 4$ sec. 20 , T. 8 S., R. 57 E.) provides the second line of control.

\section{MAJOR LITHOLOGIC UNITS AND DEPOSITIONAL ENVIRONMENTS}

According to Craig (1972) and Sando (1976a), the Madison Group in southeastern Montana represents a complexly intertongued dolomite and limestone sequence deposited on a broad shelf between the Big Snowy trough and the Williston basin on the north and the Transcontinental arch on the southeast. Basically, limestone deposition centered around the slowly subsiding Big Snowy trough and the Williston basin, whereas the dolomite accumulated along the intermittently exposed flanks of the basin and adjacent Transcontinental arch. Repeated fluctuations of the Cordilleran sea across the study area resulted in the intertonguing of limestone and dolomite units.

Correlations within the Madison Group are based on four distinctive, informal gamma-ray log markers recognized by Peterson (1981). Several of these informal markers correspond to solution-breccia and evaporite zones that have been defined in regional studies by Sando (1967, 1975), Roberts (1979), and Sheldon and Carter (1979). Specifically, the M-8.5 and M-7 markers, which are the most prominent markers of Peter- 
NORTH
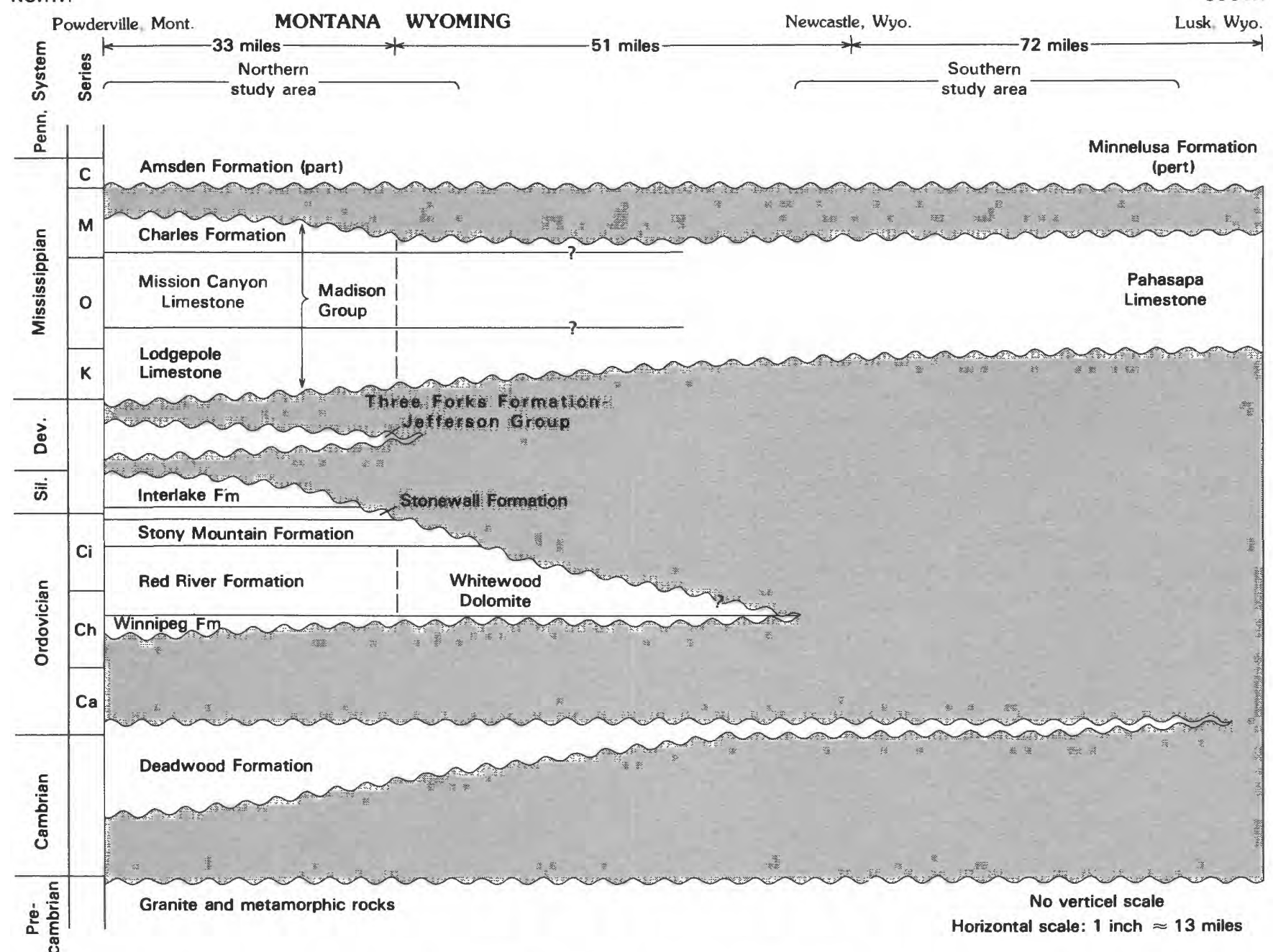

FIGURE II-1.-Generalized time-stratigraphic section showing the Madison Group, Pahasapa Limestone, Red River Formation, and adjacent units along the east flank of the Powder River Basin, Wyo.-Mont. Ordovician and Mississippian series names are abbreviated as follows: Canadian (Ca), Champlainian (Ch), Cincinnatian (Ci), Kinderhookian (K), Osagean (O), Meramecian (M), and Chesterian (C). Vertical dashed lines are arbitrary cutoffs between the Madison Group and the Pahasapa Limestone, the Red River Formation, and the Whitewood Dolomite.

son (1981) as defined in the USGS Madison Project (chap. I), correlate respectively with the upper and lower solution zones of Sando $(1967,1975)$ and the anhydrite bed at the base of interval $\mathrm{C}$ and the anhydrite bed within interval $\mathrm{B}$ of Sheldon and Carter (1979). The base of the Charles Formation is placed at the base of the anhydrite bed correlative with the M-8.5 marker (pl. 1, sec. $A-A^{\prime}$ ). Where the anhydrite bed is absent, as in the vicinity of the Black Hills, the Charles-equivalent strata are assigned either to the Mission Canyon Limestone or to the Pahasapa Limestone. The top and bottom contacts of the Red River Formation are well defined, but internal marker horizons generally are absent. Paleontologic data were not used in the construction of the cross sections.
Plate 1 also illustrates the distribution of the lithologic units in the Madison Group and the Red River Formation along sections $A-A^{\prime}$ and $B-B^{\prime}$. The Charles Formation, Mission Canyon Limestone, and Lodgepole Limestone all gradually thin southward from a combined thickness of $1,190 \mathrm{ft}$ in the Pure Oil State No. 1 to $735 \mathrm{ft}$ in the USGS Madison No. 1. The Red River Formation maintains a fairly uniform thickness of about $445 \mathrm{ft}$ across the study area.

The Lodgepole Limestone was deposited under net transgressive conditions (Sando, 1976a; Rose, 1976). The formation contains between 35 and 55 percent very finely to finely crystalline dolomite that commonly is argillaceous. Shell and crinoid debris, algae, pellets, pisolites, and oolites are minor constituents of the dolo- 
mites. The remainder comprises bioclastic limestone that contains abundant oolites, pellets, and shell debris. A minor percentage of the limestone consists of micritic units that commonly are argillaceous. Generally, the limestone beds occupy the middle part of the formation and are underlain and overlain by the dolomites (pl. 1 , secs. $A-A^{\prime}, B-B^{\prime}$ ). The lower dolomitic strata probably originated in intertidal to supratidal environments and mark the early phases of the Lodgepole transgression over the pre-Madison unconformity. In contrast, the limestone core was deposited on a high-energy open shelf during the maximum transgression of the Lodgepole seaway. Extensive oolite shoals were common features of this depositional setting (Peterson, 1981). The upper dolomite strata, also of peritidal origin, mark the gradual withdrawal of the Lodgepole sea. At the USGS Madison No. 1 (pl. 1, sec. $A-A^{\prime}$ ), the upper dolomite strata are anhydritic and indicate that at least part of the shelf during this regressive phase was quite restricted.

The Mission Canyon Limestone originated during net regression of the Cordilleran sea (Sando, 1976a; Rose, 1976). The maximum withdrawal of the sea from the shelf south of the Big Snowy-Williston embayment is recorded by an extensive 30 - to 50 -ft-thick anhydrite bed (pl. 1, sees. $A-A^{\prime}, B-B^{\prime}$ ). Later removal by leaching of the evaporite bed formed a solution-breccia zone that is equivalent laterally over broad areas and that correlates with subsurface marker M-7. The carbonate beds overlying and underlying the anhydrite bed consist of very finely to finely crystalline vuggy dolomite and oosparite to pelmicrite limestone. Dolomite beds increase southward from about 35 percent of the carbonate section in the USGS Madison No. 2 to more than 70 percent near the USGS Madison No. 1. This facies trend represents the deposition of the Mission Canyon Limestone during withdrawal of the sea from the shelf and the presence of extensive tidal flats peripheral to the south flank of the Big Snowy trough and Williston basin. The oosparite limestones probably represent high-energy shoals deposited on an open shelf during brief incursions of the sea within the regressive sequence. Two significant transgressions - one at the base of the formation and another above the medial anhydrite unit-are recorded in the Mission Canyon Limestone (pl. 1, secs. $A-A^{\prime}, B-B^{\prime}$ ) by these high-energy shoal deposits.

The Charles Formation was deposited during two regressive phases and two transgressive phases of the Cordilleran sea. A thick and extensive anhydrite bed and a laterally equivalent solution-breccia zone, correlative with subsurface marker M-8.5, represent the basal regressive phase of the Charles Formation and the equivalent Pahasapa Limestone (part). The following transgressive phase of the Charles Formation and the equivalent Pahasapa Limestone (part) is well defined and extends southward across the Powder River Basin to possibly as far as the Colorado-Wyoming State line. This basal transgressive phase is recorded mostly by micritic limestone with minor intercalations of oosparite and pelmicrite units, except in the vicinity of the Black Hills uplift (southeast corner of study area) where dolomite predominates (pl. 1 , secs. $A-A^{\prime}, B-B$ ). The upper regressive strata in the Charles Formation extend over most of the study area and are characterized by very finely to finely crystalline dolomite and local thin beds of anhydrite. The upper transgressive phase is similar in lithology and extent to the basal phase. The epeirogenic uplift, following deposition of the Charles Formation, drained the epicontinental sea from the entire shelf and permitted erosion and formation of a widespread karst topography at the top of the Madison Group.

The facies of the Red River Formation closely resemble those of the Madison Group in that dolomite units of tidal-flat origin flank limestone and evaporite strata deposited in the adjacent Williston basin (Fuller, 1961; Foster, 1972). From north to south across the study area, the dolomite in the Red River Formation increases from about 30 percent to 90 percent (pl. 1, secs. $\left.A-A^{\prime}, B-B^{\prime}\right)$. The dolomite is generally very finely to finely crystalline with scattered crinoid and shell fragments. Vugs are common constituents of the fine- to medium-grained crystalline dolomites. Micritic limestone units with local bioclastic debris and minor zones of oosparite and pelmicrite represent the remainder of the Red River carbonates. The high concentration of limestone beds near the base of the Red River Formation probably were deposited during a rapid transgression of the seaway southward on the shelf.

\section{SOUTHERN STUDY AREA}

\section{RESTORED STRATIGRAPHIC SECTIONS}

In the southern study area, the stratigraphic framework of the Madison-equivalent Pahasapa Limestone is defined by a north-south section between the Bechtel ETSI No. 0-1 well (NW1/4NE1/4 sec. 28 , T. 36 N., R. 62 W.) and the Coronado McCullough No. W-2 well $\left(\mathrm{SW}^{1 / 4} \mathrm{SW}^{1 / 4}\right.$ sec. 13 , T. 46 N., R. 64 W.) (pl. 1, sec. $C-C^{\prime}$ ). The Red River Formation is absent in this area.

Plate 1 also illustrates the distribution of the major lithofacies in the Pahasapa Limestone along section $C$ $C^{\prime}$. On the strength of the gamma-ray log markers of Peterson (1981), the Pahasapa Limestone in the southern study area seems to correlate with the lowermost 
part of the Charles Formation, the entire Mission Canyon Limestone, and the uppermost part of the Lodgepole Limestone in the northern study area (pl. 1, sec. $\left.C-A^{\prime}\right)$. Key control points along section $C-A^{\prime}$ are the Gulf Little Missouri No. 1 Federal (sec. 9, T. 55 N., R. 67 W.), Continental No. 1 Coltharp (sec. 19, T. 51 N., R. 66 W.), True Burrows No. B-19 (sec. 5, T. 49 N., R. 68 W.), and Trigood Fiddler Creek No. 272 EFCH (sec. 23, T. 46 N., R. 65 W.) (fig. I-1, pl. 1). The Pahasapa Limestone thins from about 490 $\mathrm{ft}$ in the Coronado McCullough No. W-2 to $280 \mathrm{ft}$ in the Bechtel ETSI No. 0-1.

\section{MAJOR LITHOLOGIC UNITS AND DEPOSITIONAL ENVIRONMENTS}

The Pahasapa Limestone is composed almost entirely of very finely to medium crystalline dolomite and micritic limestone. Minor constituents include crinoid, bryozoan, and other fossil debris and oolites and pellets. Commonly, dolomite nearly equals or exceeds by $10-20$ percent the limestone at any one locality. Along the Old Woman anticline (fig. I-1 and pl. 1, sec. $C-C^{\prime}$ ), limestone dominates the upper half of the Pahasapa Limestone, but farther north limestone and dolomite appear in equal abundance.

Based on faith in my correlations and those of Peterson (1981), the dolomite part of the Pahasapa Limestone along the Old Woman anticline (fig. I-1; pl 1, sec. $C-C^{\prime}$ ) appears to be equivalent to the three major anhydrite beds in the northern study area. The prominent anhydrite beds at the base of the Charles Formation and in the middle of the Mission Canyon Limestone (that is, markers M-8.5 and M-7) correlate, respectively, with the top and middle of the dolomite interval in the Pahasapa Limestone. Moreover, the anhydritic strata of the Pahasapa Limestone that rest on the $\mathrm{M}-3$ marker at the USGS Madison No. 1 seem to be equivalent to the lower part of the dolomite strata in the Pahasapa Limestone of the Old Woman anticline. The remainder of the dolomite strata in the Pahasapa Limestone at the Old Woman anticline are correlative with transgressive limestone units situated between the anhydrite beds of the Madison Group. Specifically, limestone strata of the upper transgressive episode are between the upper and middle anhydrite beds. This upper limestone extends into the southern study area as far as the Coronado Government No. 1 Tuttle (pl. 1 , sec. $C-C^{\prime}$ ) where it is replaced by dolomite in the middle third of the Pahasapa Limestone between markers $\mathrm{M}-8.5$ and $\mathrm{M}-7$. The transgressive limestone between the middle and lower anhydrite beds, on the other hand, does not extend much farther south than the USGS Madison No. 1. Dolomites in the lower third of the Pahasapa Limestone of the southern study area, between markers $M-7$ and $M-3$, are equivalent to this upper limestone unit.

The limestone part of Pahasapa Limestone along the Old Woman anticline is correlated with a transgressive limestone resting on the basal anhydrite bed of the Charles Formation (pl. 1, secs. $A-A^{\prime}, C-C^{\prime}$ ). As expected from regional facies patterns, this basal transgressive limestone is replaced by dolomite southward along section $C-A^{\prime}$ (pl. 1); but in the southern study area (pl. 1, sec. $C-C^{\prime}$ ), the interval again becomes dominated by limestone. A possible explanation for this anomalous facies change is an unrecognized paleotectonic feature.

To find this thick (as much as $100 \mathrm{ft}$ ) a Charles-equivalent unit in the Old Woman area is somewhat surprising, particularly in view of the results of studies by Andrichuk (1955), Sando (1976a, b), and Mallory (1979) that indicate the absence of Meramecian rocks throughout the central and southern Powder River Basin. Studies by Maughan (1963) in the Laramie Range and Hartville uplift, Love, Henbest, and Denson (1953) in the Hartville uplift, Gries and Mickelson (1964) and Sheldon and Carter (1979) in South Dakota, and Brobst and Epstein (1963) in the west-central Black Hills of Wyoming also suggest the absence of Meramecian rocks in the southern study area.

Despite these contradictions, I remain steadfast on my correlations until new subsurface and paleontologic data indicate otherwise. One new source of evidence that would seem to corroborate my interpretation is the recognition of Meramecian rocks at the north end of the Laramie Range (Sando, 1979). This interpretation by Sando represents a partial revision of an earlier interpretation (Sando, 1976a) that recognized no Meramecian-age rocks south of T. $45 \mathrm{~N}$. along the west side of the Powder River Basin. Now, according to Sando (1979), rocks of Meramecian age are present at least locally as far south as T. $32 \mathrm{~N}$. on the west side of the basin. Assuming an east-west trend, rocks of this age also should be present at least as far south as the southern study area. In addition, electric-log correlations in the Madison interval of the eastern Powder River Basin by Jenkins and McCoy (1958) also suggest the presence of Meramecian-age rocks in the southern study area.

\section{NATURE AND DISTRIBUTION OF AQUIFERS}

\section{LITHOLOGIC DESCRIPTION AND ORIGIN OF AQUIFERS}

Vuggy, finely to medium crystalline (sucrosic) dolomite and solution-brecciated dolomite and limestone 
constitute most of the aquifers in the Madison Group, Pahasapa Limestone, and Red River Formation. Oosparite beds locally may yield measureable quantities of ground water, but they generally are cemented tightly with sparry calcite. Karst-fill deposits also may act locally as aquifers; however, they commonly are impervious owing to clay plugging and calcite cementation.

Tectonic fracturing of the Madison and associated aquifers undoubtedly has enhanced porosity and permeability in some localities. But the degree to which fractures have contributed to the water production in a given well, if at all, is extremely difficult to document. A complex suite of data including cores, borehole-televiewer log, radioactive-tracer log (Blankennagel, 1967), and pump tests often is required to make an adequate interpretation of fracture-controlled porosity and permeability.

Detailed core descriptions by R. G. Deike (written commun., 1977) and Peterson (1978) indicated that the porous crystalline dolomite is typically tan or pink, and ranges in crystal size from 125 to 500 microns. Individual rhombs commonly are larger than 500 microns, particularly near large vugs. Many of the crystals tend to be euhedral. Vugs are ubiquitous and range from less than 0.05 in. to nearly 1 in. in diameter. The dolomites are laminated horizontally and locally contain thin discontinuous laminae of dark-gray to black organic material. Small nodules of anhydrite are scattered sparsely throughout the dolomite beds. Porosity and permeability values of probable dolomite aquifers measured from core plugs average nearly 17 percent (20 samples) and $11 \mathrm{mD}$ (millidarcies; 16 samples) in the Madison Group and 17.5 percent ( 30 samples) and 357.5 $\mathrm{mD}$ (27 samples) in the Red River Formation (Blankennagel and others, 1977; Brown and others, 1978). Intercrystalline and vuggy porosity predominate. The average permeability values of the Red River Formation are highly biased by values of $2,490 \mathrm{mD}$ and $4,890 \mathrm{mD}$ located in a 3- to 6-ft-thick vuggy dolomite (Blankennagel and others, 1977, p. 54); without these high values the average permeability is lowered to $91 \mathrm{mD}$. Median porosity and permeability measurements are 16 percent and $5.3 \mathrm{mD}$ for the Madison Group and 15.5 percent and $55 \mathrm{mD}$ for the Red River Formation.

The porous dolomites are similar to ones described by Illing, Wood, and Fuller (1967) and Roehl (1967) in other Paleozoic carbonate sequences in and around the Williston basin. They attributed the origin of the dolomite to early replacement of calcite and aragonite mud that was deposited in shallow subtidal, intertidal, and supratidal environments. Modern analogs have been recognized and described in the Bahamas (Shinn and others, 1965) and in the Persian Gulf (Illing and others,
1965). In these localities, evaporation transforms the pore water of the calcareous mud into a brine. When gypsum is precipitated, the brine becomes enriched in magnesium with respect to calcium and the dolomitization process begins. The highest porosity and permeability is developed during the final stages of dolomitization when the dolomite crystals have had an opportunity to grow larger at the expense of leached remnants of calcium carbonate (Murray, 1960; Illing and others 1967). The effect of leaching is twofold: (1) it provides carbonate ions for the growing dolomite crystals, and (2) it creates numerous vugs. Subaerial exposure (Roehl, 1967) and freshwater-salt-water interface dolomitization (Hanshaw and others, 1971), discussed later in the text, also may have enhanced significantly the porosity and permeability of these dolomite aquifers.

Solution-brecciated dolomites and limestones are characterized by poorly sorted, angular to subangular clasts of crystalline dolomite and limestone, commonly set in a matrix of red shale and siltstone, and cemented by white sparry calcite (R. G. Deike, written commun., 1977; Blankennagle and others, 1977, p. 40-42). Vugs between 1 and 3 in. in diameter, partially filled with white calcite crystals, are common features of the breccias. Many of the vugs and vertical hairline fractures in the breccias are cemented with clay or calcite. Open vugs appear to account for most of the porosity and permeability which average about 18 percent (35 samples) and $135 \mathrm{mD}$ (33 samples) (Blankennagel and others, 1977, p. 52-53). Median values are 18.5 percent porosity and $12 \mathrm{mD}$ permeability. The large disparity in average and median permeability values indicate that many of the permeability measurements are greater than $100 \mathrm{mD}$ or less than about $10 \mathrm{mD}$. Because of the variability in spacing of the interconnected vugs, many of the core samples may have penetrated only the tight matrix parts of the breccia. For this reason, many of the measurements of the core plugs recording permeability values of less than $10 \mathrm{mD}$ probably are not representative of the effective permeability of the whole rock. A value of $100-200 \mathrm{mD}$ may be more representative of the median permeability of the breccia units.

Andrichuk (1955), Roberts (1966), Sando (1974), and others have attributed the origin of the solution breccias in the Madison to selective leaching of evaporite beds, chiefly anhydrite and gypsum, and the eventual collapse and infilling of the cavity with adjacent roof rock. The most compelling evidence that favors the evaporite-leaching hypothesis includes: (1) the stratigraphic equivalence of the breccias and adjacent anhydrite units, (2) the lateral continuity of the thicker breccia zones over thousands of square miles, and (3) the 
thickness of the Madison Group having breccia units generally is less than the thickness of an adjacent section of the Madison Group having anhydrite beds. Roberts (1966) suggested that the solution breccias are principally a surface phenomenon that originated in Late Cretaceous and early Tertiary time. However, the present study and an analysis of the Madison reservoir at the Elk Basin oil field (McCaleb and Wayhan, 1969) indicate that the breccias commonly are present in the subsurface many miles from Madison outcrops. McCaleb and Wayhan (1969) as well as Sando (1974) suggested that brecciation formed penecontemporaneously with major karst features between early Meramecian and early to middle Chesterian time.

\section{RELATION BETWEEN AQUIFERS AND INTERVAL VELOCITY}

Probable water-bearing zones in the Madison Group, Pahasapa Limestone, and Red River Formation commonly are associated with low-interval velocity values. The water-bearing zones are identified from cores, drill cuttings, drilling history, radioactive-tracer logs, and production data. There seems to be an inverse relation between effective porosity and interval velocity that is exemplified best in the Red River part of the USGS Madison No. 2 (pl. 1, sec. $A-A^{\prime}$ ) and in the Mission Canyon interval of the Sam Gary Bell Creek Madison No. 1 (pl. 1, sec. $B-B^{\prime}$ ). In the example from the Red River Formation, porous crystalline dolomite has a velocity of $15,388 \mathrm{ft} / \mathrm{s}$ (feet per second), whereas adjacent mud-supported limestone has a velocity of $20,014 \mathrm{ft} / \mathrm{s}$. In the examples from the Mission Canyon Limestone, velocities for the respective porous and tight intervals are $16,667 \mathrm{ft} / \mathrm{s}$ and $20,408 \mathrm{ft} / \mathrm{s}$. The aquifer in this example is probably entirely a solution-breccia unit.

The plot of interval velocity against porosity illustrated in figure II-2 presents an indication of the range of porosity and interval velocity in the Madison Group and the Red River Formation. The data used in this plot are from the USGS Madison wells Nos. 1 and 2 (Blankennagel and others, 1977; Brown and others, 1978; R. G. Deike, written commun., 1977). Porosity was determined from core plugs, and interval velocities were calculated from sonic logs. Classification of samples as either aquifer or aquiclude is based on lithologic characteristics such as the presence or absence of large open vugs. In addition, the permeability of the individual core plugs, where known, is listed next to the appropriate sample point on the plot. The core plugs were obtained from depths of $2,461-3,609 \mathrm{ft}$ in the USGS Madison No. 1 and 6,890-8,859 $\mathrm{ft}$ in the USGS Madison No. 2.
Although there is a high degree of scatter, the data depict a general trend of increasing porosity and permeability with decreasing interval velocity. Major boundaries at 10-percent porosity and 18,500 ft/s appear to partition those samples classified as probable aquifers from those classified as probable aquicludes. Nearly 90 percent of the samples classified as aquifers have porosities greater than 10 percent and interval velocities of less than $18,500 \mathrm{ft} / \mathrm{s}$. Similarly, about 70 percent of the samples classified as aquicludes have porosities less than 10 percent and interval velocities greater than $18,500 \mathrm{ft} / \mathrm{s}$. About 25 percent of the total 268 samples fall outside the limiting parameters discussed.

The best aquifers are judged to be those rocks with a total porosity greater than 17 percent and an interval velocity less than $17,500 \mathrm{ft} / \mathrm{s}$ (fig. II-2). Permeability values in the excellent aquifer category average 344 $\mathrm{mD}$ in contrast to an average of $162 \mathrm{mD}$ for measurements in the class identified as marginal to good aquifers. These values are undoubtedly on the low side because, as mentioned earlier, the small core plugs often do not measure adequately the interconnected void space of the whole core. Two vuggy macrocrystalline dolomite samples on the crossplot, with measured permeabilities of $5.9 \mathrm{mD}$ for the core plug and $38 \mathrm{mD}$ for the whole core, help to corroborate this point.

The data plotted in figure II-2 also indicate that the total porosity of a given aquifer cannot be calculated accurately from the Wyllie equation (Wyllie and others, $1956,1958)$. In all aquifers, we find that the porosity derived from the Wyllie equation is 5-10 percent lower than the porosity measured from the corresponding core plug. This difference commonly is observed in vuggy or fractured carbonate rocks and the porosity derived from the Wyllie formula tends to be lower than the measured porosity by an amount approaching the secondary porosity (Schlumberger Limited, 1972, p. 39). Input parameters used to solve the Wyllie equation include the following: (1) interval velocity of the zone of interest derived from a sonic log, (2) velocity of the dolomite $(23,000 \mathrm{ft} / \mathrm{s})$ or limestone $(22,000 \mathrm{ft} / \mathrm{s})$ grains, and (3) velocity of water $(5,300 \mathrm{ft} / \mathrm{s})$ for the fluid velocity.

Irrespective of porosity, nearly 80 percent of the aquicludes plotted in figure II-2 have interval velocities greater than $18,500 \mathrm{ft} / \mathrm{s}$, and 90 percent of the aquifers plotted in figure II-2 have interval velocities slower than this. A major disadvantage of using solely interval velocity to differentiate between aquifers and aquicludes is that about 20 percent of the aquicludes may be classified incorrectly as aquifers. Many of the lowvelocity aquicludes may be recognized by their higher gamma-ray log response because they are silty and 


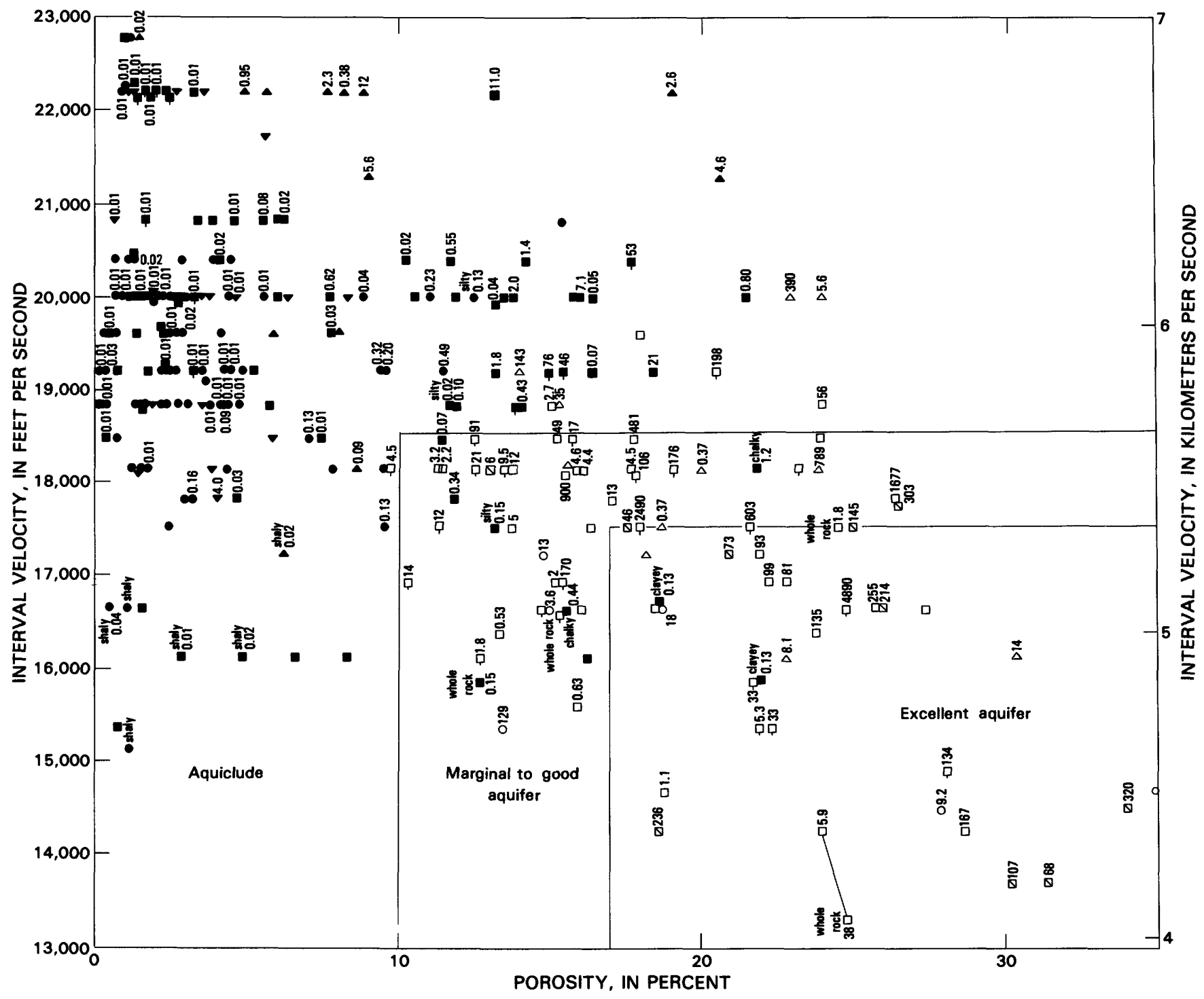

EXPLANATION

MADISON GROUP

PROBABLE AQUIFER

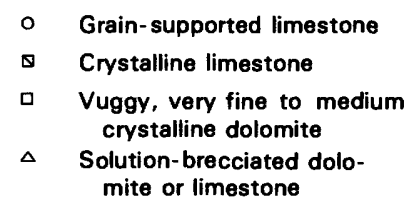

PROBABLE AQUIFER

Q Vuggy, very fine to medium crystalline dolomite.
PROBABLE AQUICLUDE

- Mud-supported limestone

- Microcrystalline or mud. supported dolomite

- Tightly cemented solutionbrecciated dolomite or limestone

- Karst breccia

RED RIVER FORMATION

\section{PROBABLE AQUICLUDE}

- Microcrystalline or mud-supported dolomite

FigURE II-2.-Plot of interval velocity (in feet per second and kilometers per second) versus porosity in Madison Group and Red River Formation cores from the USGS Madison Nos. 1 and 2 water wells. Sample number is 268 . Porosity and permeability data are compiled from Blankennagel and others (1977), Brown and others (1978), and R. G. Deike (written commun., 1977). Numbers at data points are permeability values in millidarcies $(\mathrm{mD})$. 
shaly carbonate units. The plot also indicates that about 10 percent of the aquifers have interval velocities greater than $18,500 \mathrm{ft} / \mathrm{s}$ and would be misidentified as aquicludes if only sonic log data were investigated. Except for these minor discrepancies, the use of sonic log data to aid in the differentiation of aquifers and aquicludes in the Madison Group, Pahasapa Limestone, and Red River Formation basically is credible, and these data will be used in the following section.

\section{DISTRIBUTION OF AQUIFERS}

I have delineated the most important aquifer zones on the stratigraphic sections (pl. 1) by using a combination of interval velocities, core samples, drill cuttings, neutron logs, and water-production data. Three categories of aquifers are recognized: (1) vuggy macrocrystalline dolomite, (2) solution-brecciated dolomite and limestone, and (3) others such as crystalline limestone and oosparite limestone. The three types of aquifers are discrete, isolated zones as shown in plate 1, but there is probably at least some vertical communication between these aquifers zones.

Solution-brecciated dolomite and limestone units in the upper half of the Mission Canyon Limestone, with a combined thickness of as much as $210 \mathrm{ft}$, constitute the most important water-producing zone in the Madison Group (pl. 1, secs. $A-A^{\prime}, B-B^{\prime}$ ). The principal brecciated zones are up-stratigraphic-dip equivalents of the two major anhydrite units. The zones correlate approximately with markers $M-8.5$ and $M-7$ and are present south of the pinchout of the anhydrite edges. At places, the entire section between the markers has been brecciated. The thickest section of continuously porous breccia presently known is in the area of the Madison water-supply wells at the Bell Creek oil field. In the Sam Gary Bell Creek Madison No. 1 (pl. 1, sec. $B-B^{\prime}$ ), the aquifer is about $210 \mathrm{ft}$ thick and flows water at a rate of $250 \mathrm{gal} / \mathrm{min}$ from 5.5-in. diameter casing. On pump, the well yields $350 \mathrm{gal} / \mathrm{min}$. Several miles away, the Sam Gary No. 2 Madison, which has a lower surface elevation and was completed with a larger diameter casing, flows $890 \mathrm{gal} / \mathrm{min}$ and pumps more than 1,000 $\mathrm{gal} / \mathrm{min}$ from the same stratigraphic interval (pl. 1, sec. $\left.B-B^{\prime}\right)$. Another reasonably productive water well, the USGS Madison No. 1 , flows between 70 and $96 \mathrm{gal} / \mathrm{min}^{1}$ from the same stratigraphic interval, which is about 55 percent of the total production of water from the Madison Group in this well.

Locally, vuggy crystalline dolomite units in the Charles, Mission Canyon, and Lodgepole, and oosparite units in the Lodgepole Limestone are aquifers (pl. 1,

\footnotetext{
${ }^{1}$ The range of flow-rate values represents differences between the radioactive tracer and flowmeter (spinner) surveys (R. K. Blankennagel, oral commun., 1977).
}

secs. $\left.A-A^{\prime}, B-B^{\prime}\right)$. The vuggy crystalline dolomite aquifers commonly are between 30 and $80 \mathrm{ft}$ thick, laterally continuous for tens of miles, and may grade laterally into other aquifer units. Thin oosparite aquifers appear throughout the Madison Group, but the thickest ones are in the lower half of the Lodgepole Limestone. Although generally thin, the oosparite aquifers total $130 \mathrm{ft}$ where they are present on the broad northplunging nose of the Black Hills uplift (fig. I-1; pl. 1, secs. $\left.A-A^{\prime}, B-B^{\prime}\right)$. Most of the vuggy crystalline dolomite and oosparite strata have excellent porosity and permeability for an oil reservoir; however, they are only marginal to good as aquifers. The chief reason for the lower suitability of the vuggy crystalline dolomite as an aquifer seems to be the lack of large vugs greater than 0.2 in. in diameter.

Vuggy macrocrystalline dolomites compose the major aquifer zones in the Red River Formation. Typically, these dolomites occupy two or three continuous horizons, between 20 and $50 \mathrm{ft}$ thick, in the upper half of the Red River Formation. Additional zones as thick as $115 \mathrm{ft}$ also may be present in the lower half of the formation. Water yield from these aquifers can be extremely high and commonly exceeds the production from the Madison Group. For example, in the USGS Madison No. 1, the flow from the Red River Formation totalled between 284 and $339 \mathrm{gal} / \mathrm{min}$, whereas the flow from the Madison Group totalled between 150 and 183 $\mathrm{gal} / \mathrm{min}$. The same general relationship was observed in the USGS Madison No. 2, although the total volume of water produced from each formation is considerably less. An apparently reversed relationship of the flow from the Red River Formation and the Madison Group has been noted in the Bell Creek water-supply wells. The flow from the Madison Group reportedly exceeds that from the Red River Formation; however, interval velocity values from the Red River Formation in the Bell Creek wells (pl. 1 , sec. $B-B^{\prime}$ ) are similar to those in the USGS Madison No. 1 (pl. 1, sec. $A-A^{\prime}$ ), suggesting that the Red River Formation may not have been tested properly at Bell Creek.

The best aquifers in the Pahasapa Limestone are restricted primarily to two continuous, 30 - to 100 -ft-thick horizons of vuggy macrocrystalline dolomite (pl. 1, sec. $C-C^{\prime}$ ). They are approximately equivalent to strata in the Mission Canyon Limestone and in the uppermost Lodgepole Limestone. Specifically, the aquifers seem to be equivalents of the thick anhydrite beds associated with markers M-8.5 and M-7 and the upper regressive phase of the Lodgepole Limestone above marker $\mathrm{M}-3$. Combined pumping yields from these two zones range from flows of about $800 \mathrm{gal} / \mathrm{min}$ in the Coronado Collins No. W-1 to less than $60 \mathrm{gal} / \mathrm{min}$ in the Bechtel ETSI 
No. 0-1 (Anderson and Kelly, 1976). Water wells on the axis of the Black Hills monocline, such as the Coronado West Mule Creek No. 1-A, Coronado Collins No. W-1, and Coronado McCullough W-2, generally are significantly better producers than are wells situated on the homoclinally dipping east flank of the Powder River Basin west of the monoclinal axis (fig. I-1; Hodson, 1974). Fracturing that resulted during the tectonic evolution of the Black Hills monocline and subsequent enlargement of the fractures by groundwater solution appear to be the primary mechanisms responsible for this better production near the axis of the monocline.

In summary, this analysis indicates that the best aquifers are associated with (l) solution-brecciated dolomite and limestone units in the upper part of the Mission Canyon Limestone, (2) vuggy macrocrystalline dolomite units in the Red River Formation, and (3) vuggy macrocrystalline dolomite units with probable fracture overprinting in the Pahasapa Limestone.

\section{DEPOSITIONAL AND DIAGENETIC HISTORY OF MADISON AND ASSOCIATED AQUIFERS}

The following discussion is a preliminary attempt to establish the chronological order of complexly interrelated depositional and diagenetic events that are believed to have shaped the Madison aquifer. A major reason for constructing this model is to use these concepts to predict the trends of high-yield aquifers. The model is not intended to be a predictive tool for locating individual wells, but rather a means of locating aquifers associated with areas of thick, porous, solution breccia or vuggy macrocrystalline dolomite.

The depositional and diagenetic model comprises seven major phases: (1) extensive dolomitization of inner-shelf limey sediments beneath and laterally adjacent to evaporites; (2) subaerial exposure of dolomitized sediments, desiccation and brecciation, and introduction of meteoric water during terminal phases of evaporite deposition; (3) post-middle Meramecian-pre-early Chesterian epeirogenic uplift and nearly simultaneous formation of regional karsting and solution breccias; (4) burial beneath Chesterian sediments; (5) post-late Chesterian-pre-late Morrowan epeirogenic uplift and erosion and second stage of karst and solution-breccia formation; (6) burial beneath Pennsylvanian sediments and infilling of the karst surface by terrigenous mud; and (7) Late Cretaceous to recent post-burial modification by tectonism and ground-water flow. Salient features of these major phases are summarized in figure II-3.
The confinement of the thick anhydrite beds in the upper Mission Canyon Limestone and the lower Charles Formation to the flanks of the Williston basin and Big Snowy trough (Sheldon and Carter, 1979) suggests that the beds originated on a wide, restricted shelf. Most of the evaporites probably formed in an arid climate during low stands of the sea, either on a wide unbarred shelf with poor circulation or in a lagoon separated from the open sea by shoals near the shelf margin (Sando, 1976a; Sheldon and Carter, 1979). A broad coastal sabkha probably bordered much of the restricted shelf on its landward side (fig. II-3, phase I).

Based on the apparent lateral equivalence of the thick anhydrite beds and the dolomite strata on the interior shelf, dolomitization seems to have coincided with the same major regressive events that formed the anhydrite beds. The lowering of the sea level increased the salinity of the interstitial water within the bioclastic and pelletal lime muds of the shelf, and gypsum and anhydrite were precipitated. The resultant interstitial brines were enriched in magnesium and they dolomitized the aragonite-rich host sediments. Sediments underlying the restricted shelf or lagoon were dolomitized by refluxing brines that seeped slowly through them (Adams and Rhodes, 1960), whereas those sediments beneath the sabkha were dolomitized by brines in place that were trapped in the pore space (Kinsman, 1969). Most of the earlier formed gypsum probably was replaced by anhydrite or was dissolved, and the ions migrated to a new site where they precipitated as anhydrite.

Both reflux- and sabkha-type dolomites tend to be microcrystalline with typical anhedral crystals ranging from 5 to 20 microns (Adams and Rhodes, 1960; Illing and others, 1967; Roehl, 1967). Many of the Madison dolomite units are of this type; however, those with the better aquifer properties have considerably larger (60-500 microns) euhedral crystals. Roehl (1967) showed that some highly burrowed intertidal and laminated supratidal dolomites may be composed of 20 - to 50-micron euhedral crystals, but these crystals still are smaller than the crystals in the major aquifers.

A partial answer to this problem may involve the introduction of meteoric water to the sabkha-type dolomite sediments during the terminal phases of evaporite deposition on the shelf. At this time, sea level had lowered significantly and exposed a large area behind the shoreline to subaerial processes (fig. II-3, phase II). Desiccation and brecciation of many of the dolomite units could have created large interclast voids that facilitated the infiltration and percolation of the meteoric water. Syndepositional and syndiagenetic tectonism along regional fracture systems (Brown, 1978; Brown and others, 1982) locally may have controlled the dis- 
persal of ground water. The ground water probably was derived from flooding of the subaerially exposed surface during periods of torrential rainfall and fluvial inflow from the ancestral Front Range and Transcontinental arch to the south, where Precambrian basement was exposed intermittently (Maughan, 1963; Sando, 1976a).

Mixing of the fresh water with hypersaline interstitial brines of the dolomitized muds beneath the sabkha may have reduced drastically the salinity of the brines without appreciably reducing their high ratio of $\mathrm{Mg}^{++}$ to $\mathrm{Ca}^{++}$(Hanshaw and others, 1971; Folk and Land, 1975). The lower salinity promoted a slower rate of crystallization with the net result of well-ordered, large (50-500 microns), euhedral dolomite crystals formed in the available void spaces.

Additional subaerial processes accompanying the restriction of the shelf sea may include partial solution and removal of sabkha evaporites and minor karst formation. These processes may account for the absence of anhydrite units in the outermost reaches of the sabkha.

In the final regressive stages, a broad evaporite pan probably occupied the south flank of the Williston basin and Big Snowy trough (fig. II-3, phase II). Most of the time the pan probably contained a shallow, hypersaline body of water, but at other times it was nearly dry. Subsidence accompanying intermittent flooding of the shallow restricted shelf allowed deposition of as much as $80 \mathrm{ft}$ of the anhydrite. Thin, interbedded microcrystalline dolomite units probably formed as algal mat deposits in the evaporite depocenter. In some places the anhydrite may have diagenetically replaced underlying algal mats (Fuller and Porter, 1969). Pelletal calcareous muds beneath anhydrite units were not dolomitized extensively because they probably were protected from infiltrating brines by the dense impervious anhydrite beds. Sea-level rise ended the cycle, and pelletal lime mud was deposited on the anhydrite.

Post-middle Meramecian-pre-early Chesterian epeirogenic uplift of the entire Cordilleran shelf placed the upper part of the Madison carbonates in the vadose zone (fig. II-3, phase III). The intense leaching of this surface by circulating vadose water produced a widespread, well-defined karst terrrane, including enlarged joints, sinkholes, and caves, in the upper $400 \mathrm{ft}$ of the Madison Group (Sando, 1974). Most of the void spaces are now plugged tightly by clay, silt, and sand derived from insoluble constituents in the Madison Group and terrigenous clastic sediments accompanying the early phases of post-Madison deposition.

Karst features locally extended downward into the two major anhydrite-bearing intervals of the Mission Canyon Limestone and initiated wholesale removal of these units. The anhydrite-leaching process probably began along the northern flank of the Transcontinental arch, where erosion had exposed older parts of the Madison Group, and progressed northward down the regional potentiometric gradient. Much of the anhydrite removal appears to have been in the phreatic zone (Sando, 1974). The first of the leached anhydrite beds was probably less than $3 \mathrm{ft}$ thick and did not result in any significant removal of support from the overlying carbonate units. Consequently, the opposing roof and floor rock were juxtaposed without fracturing as the anhydrite dissolved. The only remaining vestige of the anhydrite beds in the southern study area is probably a thin silt and clay horizon derived from weathering products of the karst terrane. Where thicker anhydrite beds were leached farther north, the overlying carbonate strata collapsed and were brecciated. Whether the brecciation process consisted of the sudden collapse of the roof into a large void or by gradual subsidence accompanied by evaporite flowage and small-scale solution (Stanton, 1966) cannot be determined. Whatever the mechanism, the leaching must have been highly efficient because isolated anhydrite pillars have not been reported in this region. The solution-breccia zones extend many tens of miles north into Montana and increase to thicknesses of as much as $115 \mathrm{ft}$ (fig. II-3, phase III). At some places, brecciated zones that commonly are separated by unbroken carbonate strata may merge to form a composite unit more than $210 \mathrm{ft}$ thick. Leaching and brecciation ended abruptly when the region was buried beneath Chesterian sediments (fig. II3 , phase IV). The Big Snowy Group and equivalent rocks attained a thickness of as much as $900 \mathrm{ft}$ in central Montana and probably much less on the Wyoming shelf (Maughan and Roberts, 1967).

Post-late Chesterian-pre-late Morrowan epeirogenic uplift of the Wyoming shelf caused the Chesterian rocks to be removed from southeast Montana and Wyoming except for the basal Kibbey Formation and equivalent units such as the Fairbank Formation (fig. II-3, phase V). Those parts of the underlying Madison that were not protected by the erosional remnants of Chesterian rocks had a second stage of karst and solution-breccia formation.

Ground water that circulated through the brecciated units carried fine-grained terrigenous debris that eventually tightly plugged the caverns and fracture spaces. The terrigenous debris entered the breccias through the many sink holes and other karst features and gradually became dispersed in the direction of regional ground-water flow. Generally, the breccias closest to the karst features were plugged first, whereas those breccias near the active solution front, in the deeper subsurface, were affected the least. Anhydrite cement 

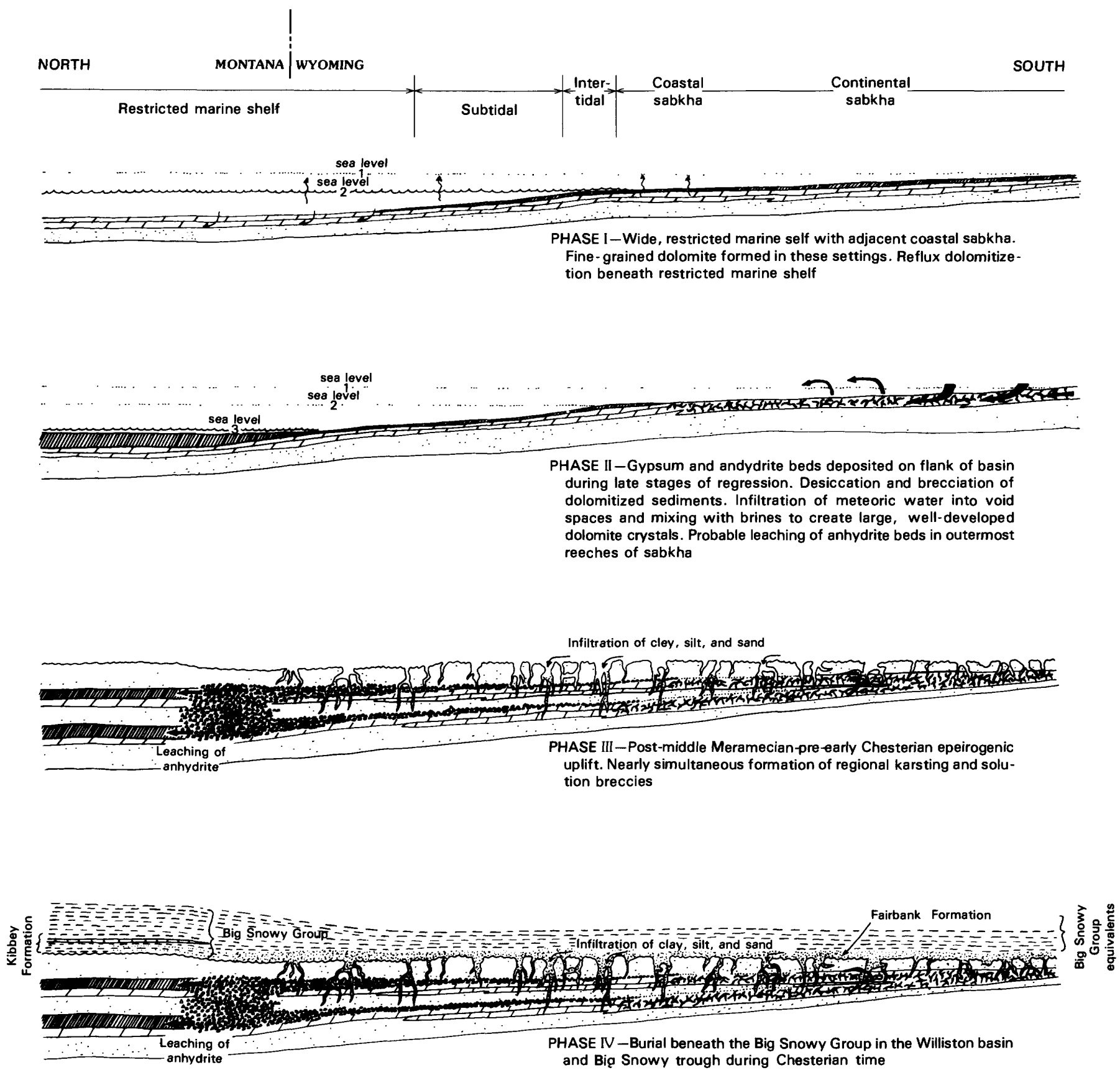

FIGURE II-3 (above and facing page).-Depositional and diagenetic model summarizing the formation of the Madison aquifer.

also may plug locally the brecciated strata. Burial of the Madison Group and the Big Snowy Group beneath Pennsylvanian sediments ended the second episode of karst and solution-breccia formation (fig. II-3, phase VI).

The solution-brecciation process probably was rejuvenated in post-Late Cretaceous time by uplift of the
Black Hills and Big Horn Mountains as proposed by Roberts (1966). The process probably is active today (fig. II-3, phase VII). Additional late-stage modifications of aquifers in the Madison Group and Pahasapa Limestone include fracturing by Late Cretaceous to early Tertiary tectonism and differential solution of carbonate rocks by circulating ground water. 
NORTH
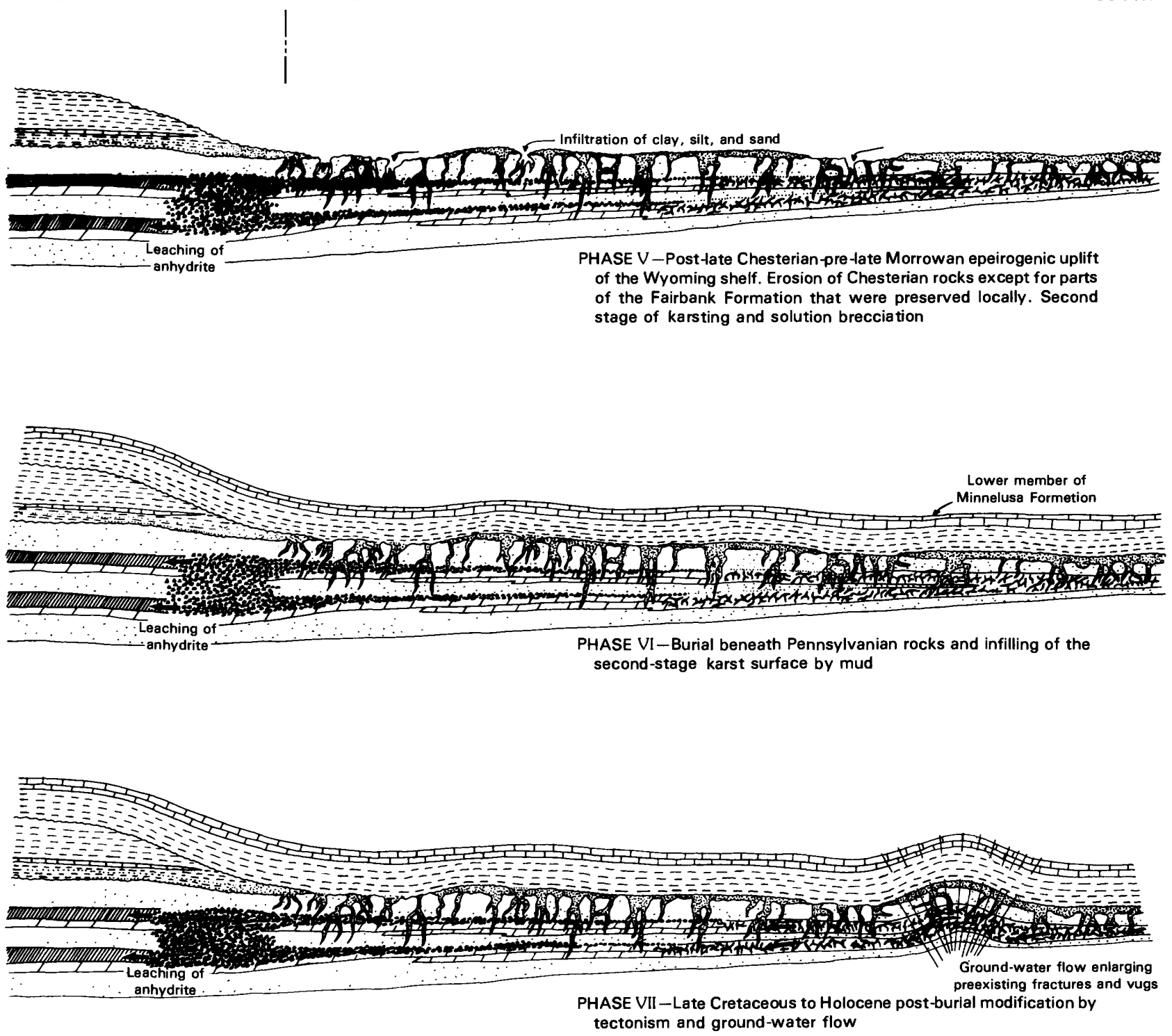

EXPLANATION

Nodular anhydrite

Sandstone and siltstone

Very finely crystalline dolomite

Micritic limestone

Desiccated and brecciated dolomite with well-developed dolomite crystals in vugs
PHASE VI-Burial beneath Pennsylvanian rocks and infilling of the cond-stage karst surface by mud
Ground-water flow enlarging tectonism and ground-water flow 
The processes that shaped the aquifers in the Madison Group and Pahasapa Limestone probably also controlled the development of the high-yield dolomite aquifers in the upper part of the Red River Formation. In the Red River Formation of the Williston basin, the dolomite aquifers correlate with a zone of 2- to 20 -ftthick anhydrite marker units recognized by Fuller (1961) and Kolm and Louden (1979a, b, c). All highyield dolomite aquifers in the Red River Formation, however, are not lateral equivalents of anhydrite-bearing horizons. The most notable exception is a thick aquifer of highly dolomitized carbonate rock in the lower half of the Red River Formation. In the USGS Madison No. 1, water flows from this aquifer at a rate of 80-105 gal/min. This aquifer appears to thicken toward the south (Peterson, 1981). The porosity and permeability in these strata most likely were increased during the period of erosion and truncation of the Red River Formation prior to the deposition of the Madison Group. Extensive exposure of the Red River Formation during this erosional episode permitted vadose ground water to percolate through dolomitized horizons in the lower and upper Red River Formation and to enhance any preexisting intercrystalline, vuggy, or fracture porosity. Because the dolomites in the upper Red River Formation probably were more porous at the time of the pre-Madison truncation than those in the lower Red River, the porosity of the upper Red River dolomites was enhanced more extensively.

\section{POTENTIAL REGIONS OF HIGH WATER PRODUCTIVITY}

By applying the depositional and diagenetic model to existing well data, three major aquifer trends are defined (fig. II-4). The best aquifer in the Madison Group in the northern study area is in the upper half of the Mission Canyon Limestone. This is the 200-ft-thick aquifer that comprises brecciated carbonate beds equivalent to the two major anhydrites and intervening strata in the Mission Canyon Limestone. The aquifer appears to be most productive adjacent to the anhydrite beds where leaching presumably is still active and interclast voids have not been plugged with terrigenous debris. The southern extent of this aquifer is uncertain, but it is estimated to be about $12 \mathrm{mi}$ southwest of the Sam Gary Bell Creek Madison No. 1 (fig. II-4). The optimum water production from this aquifer appears to be within a zone about $25-30 \mathrm{mi}$ wide that trends westnorthwest across the northern study area (fig. II-4). However, the southern boundary may be more irregu- lar and may extend farther into the Powder River Basin than is shown on figure II-4. High-yield water wells in this zone include the Sam Gary Bell Creek Madison No. 1 (sec. 27, T. 8 S., R. 54 E.), Sam Gary No. 2 Madison water well (sec. 21, T. 8 S., R. 54 E.), Gary No. 3 (sec. 29, T. 8 S., R. 54 E.), Gary No. 1 Ranch Creek (sec. 22, T. 9 S., R. 53 E.), and USGS Madison No. 1 (sec. 15, T. 57 N., R. 65 W.). This proposed zone of high water productivity in the Madison Group is not recognized by MacCary and others (1983) in their study of potentially favorable areas for largeyield wells in the Madison. The aquifer in the upper Mission Canyon Limestone probably is the best aquifer that can be mapped with surface seismic data because of its 200-ft thickness and its relatively high acousticimpedance contrast with adjacent units.

The aquifer in the Red River Formation yields the most water where the nearly ubiquitous macrocrystalline dolomite units in the upper part of the formation are juxtaposed with porous and permeable strata in the lower part. Judging from the USGS Madison No. 1, Union No. 1 Newton (sec. 23, T. 9 S., R. 59 E.), and the Bell Creek wells, the best aquifer of the Red River Formation trends east-west through the southernmost part of the northern study area subparallel to the beveled edge of the formation (fig. II-4). This aquifer probably should be detectable with surface seismic methods because it consists of a thick section (as much as 360 $\mathrm{ft}$ ) of porous dolomite that has relatively low acoustic impedance values. This proposed zone of high water productivity in the Red River Formation is recognized by MacCary and others (1983) in their study of potentially favorable areas for large-yield wells in the Red River Formation.

In the southern study area, the fractured macrocrystalline dolomite units in the Pahasapa Limestone associated with the Black Hills monocline and the Old Woman anticline appear to be the best aquifers (fig. II-4). Away from these structures, equivalent crystalline dolomite units are only fair aquifers. High-yield water wells near the town of Newcastle, Wyo., produce from these aquifers along the Black Hills monocline trend. Seismic detection of these high-yield, fractured dolomite zones in the Pahasapa Limestone may be difficult because they are only $65-80 \mathrm{ft}$ thick and the acoustic-impedance contrast with adjacent impervious limestone units is low. This proposed zone of high water productivity in the Pahasapa Limestone is not recognized by MacCary and others (1983) in their study of potentially favorable areas for large-yield wells in the Madison Limestone. 


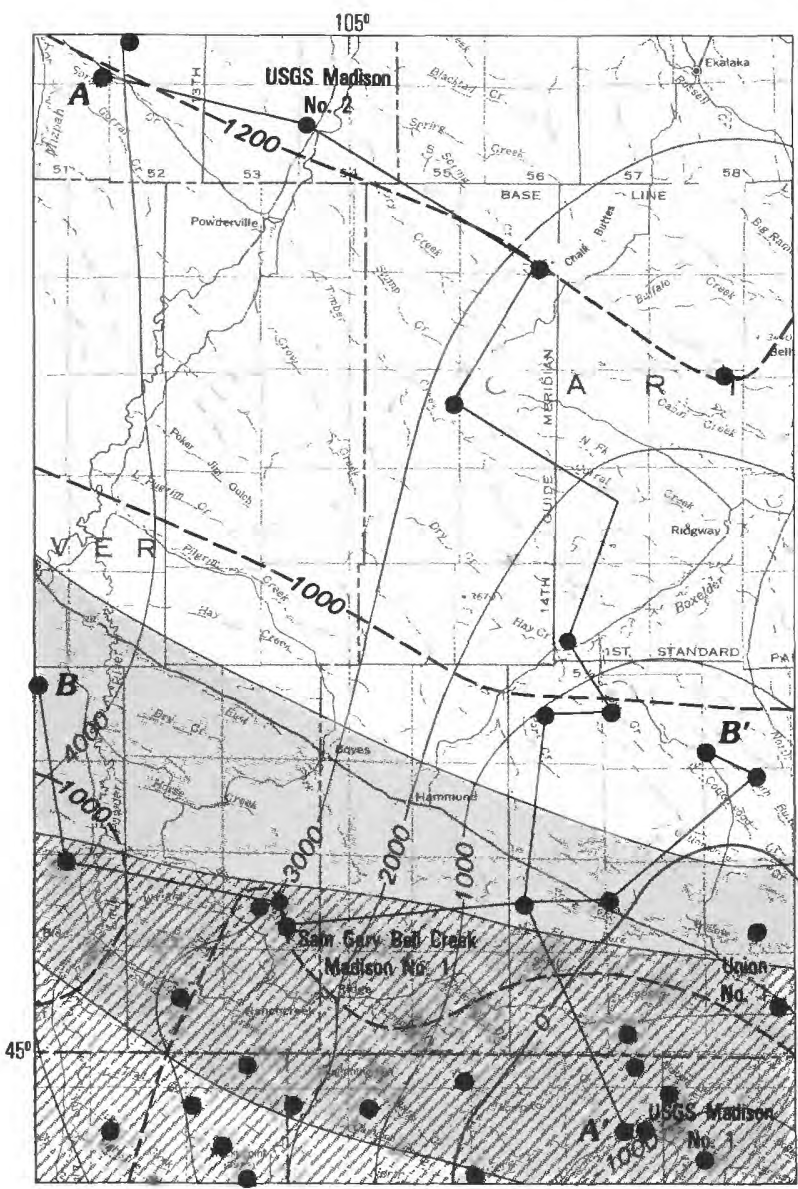

NORTHERN STUDY AREA

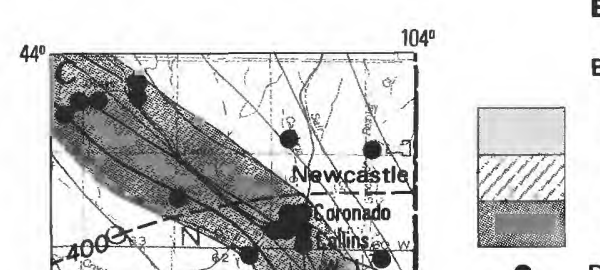

EXPLANATION

BEST AREA TO EXPLORE FOR WATER IN THE:

Madison Group

Red River Formation

Pahasapa Limestone

DRILL HOLE REACHING THE MADISON GROUP

STRUCTURE CONTOUR ON TOP OF MADISON GROUP Contour interval 1000 feet

ISOPACH, IN FEET, OF MADISON GROUP AND EQUIVALENT UNITS

ANTICLINE - Showing trace of axial plane and direction of plunge

$A-\boldsymbol{A}^{\prime}$ LINE OF SECTION

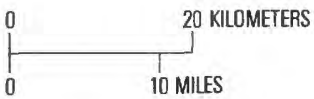

FIGURE II-4.-Map of the northern and southern study areas showing potential trends of high water productivity in the Madison aquifer. See plate 1 for cross sections of lines of sections $A-A^{\prime}, B-B^{\prime}$, and $C-C^{\prime}$ and figure $\mathrm{I}-1$ for general location. 


\author{
A SEISMIC-STRATIGRAPHIC INVESTIGATION OF THE MADISON AND ASSOCIATED \\ AQUIFERS-APPLICATION TO GROUND-WATER EXPLORATION, POWDER RIVER BASIN, \\ MONTANA-WYOMING
}

\title{
DESCRIPTION OF THE VERTICAL SEISMIC PROFILING METHOD
}

\author{
CHAPTER III
}

By A. H. BALCH

\section{CONTENTS}

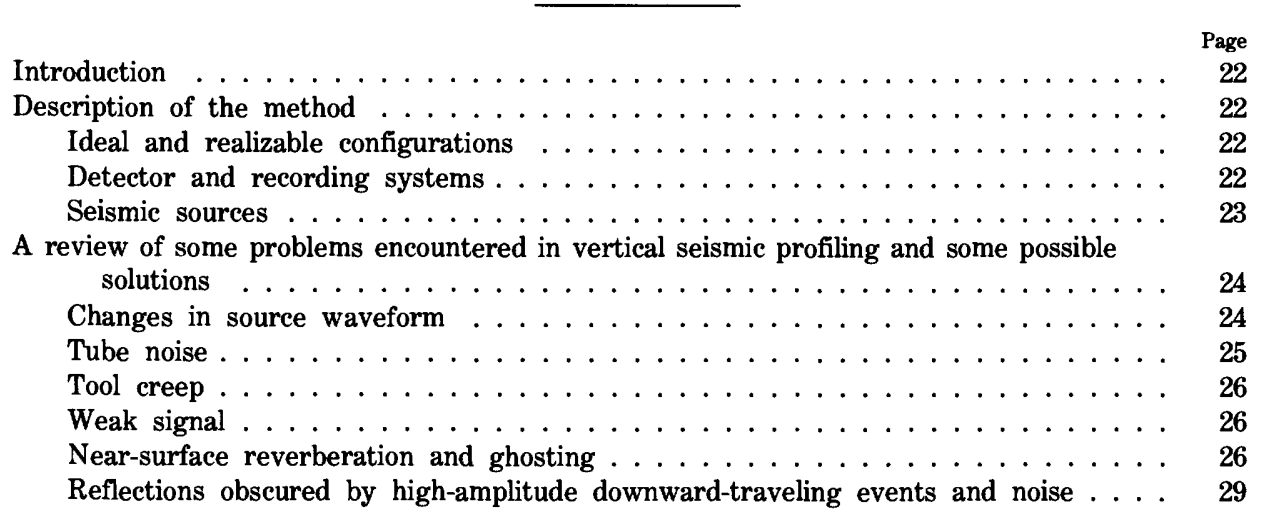

\section{ILLUSTRATIONS}

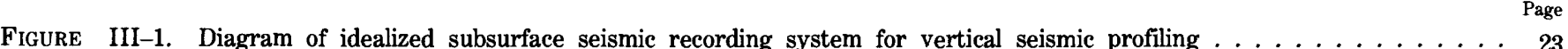

III-2. Idealized plot of data obtained from the vertical seismic profile recording system shown in figure III-1 . . . 23

III-3. Diagram showing source monitor waveforms, shaping filters, and convolution products . . . . . . . . . . 24

III-4. Stacked, edited vertical seismic profiliing data from the Pfister Fee No. 1 well, Wyoming . . . . . . . . . 25

III-5. Composite vertical seismic profile from Coronado Collins Well No. W-1 near Neweastle, Wyo., showing pronounced

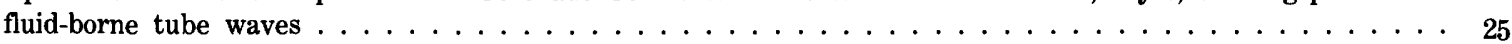

III-6. Traces showing example of tool-creep noise $\ldots \ldots \ldots \ldots \ldots$

III-7. Specimen recordings at $7,050-7,100$ feet in the USGS Madison No. 2 well . . . . . . . . . . . . . . 27

III-8. Sample recordings described in figure III-7 after composite . . . . . . . . . . . . . . . . . . . 27

III-9. Vertical seismic profile recordings from Coronado Collins Well No. W-1 showing near-surface reverberation effects . . 28

III-10. Autocorrelations of the recordings shown in figure III-9 . . . . . . . . . . . . . . . 28

III-11. Velocity-filtered vertical seismic profile data from the USGS Madison No. 2 well, showing upward-traveling events . . 29 


\section{INTRODUCTION}

Vertical seismic profiling (VSP) involves recording manmade seismic disturbances (shots) at many levels in a deep well. The seismic source may be on the surface, in a shallow source hole, or in an adjacent deep well. This type of field configuration is distinctly different from that used in conventional surface (horizontal) seismic profiling in which the seismic detector(s) and the source are located at the surface. Because the profile is vertical, the wave field can be observed as it progresses into the ground and as reflections are generated at various interfaces within the earth.

To develop a seismic technique for detecting waterproducing zones, a desirable determination is what acoustic properties (if any) of a target horizon distinguish the porous-productive facies from the tight-dry facies. How is the one facies distinguishable from the other from an acoustic point of view? To answer this question, we would like to measure the acoustic properties of representative stratigraphic sections. We would like to measure these properties in place and under something close to seismic exploration conditions. We would like to use a seismic source, seismic detectors, and recording systems similar to those used in conventional surface seismic exploration configurations.

If we can identify acoustic differences between the productive and barren end members, we may be able to design a surface seismic procedure to explore for high-yield aquifers. Knowledge of the acoustic differences can serve as a guide to what to look for on surface data to identify porosity buildups. Knowledge of the acoustic differences of the end members may indicate that some new surface exploration procedure must be developed. For example, we might learn that porosity in the Madison aquifer interval can be detected seismically from the surface on the basis of a change in reflected waveforms, but only if reflections as high as $150 \mathrm{~Hz}$ (hertz) can be recorded. This requirement would mean that we must develop a surface procedure to generate and record these frequencies and restrict the exploration effort to those situations in which reflections in this frequency band can be obtained.

Vertical seismic profiles can be used to identify reflected events on surface seismic profiles with a high level of confidence, because reflected events can be detected at their point of origin in the earth, tracked level by level to the surface, and tied into a surface profile. Vertical seismic profiles enable study of the evolution, or change, in seismic waveforms as they progress through the earth. Scattering, attenuation, and interbed reflections all contribute to the evolution. The surface recorded wave train from a reflecting surface at depth is different from the seismic wavelet produced by the source. With VSP data, the details of the conversion of source waveform into a surface recorded seismic reflection can be observed and these details taken into account in processing and interpreting surface data.

\section{DESCRIPTION OF THE METHOD}

\section{IDEAL AND REALIZABLE CONFIGURATIONS}

Figure III-1 is an idealized cross-sectional view of a VSP layout. A seismic source located near or at the surface is energized, and an array of seismometers, $R$, is clamped in a well. All downward and upward-traveling (reflected) events are recorded in sequence at every level in the hole. Typical seismometer spacing would be $10-15 \mathrm{ft}$. With an ideal source wavelet (no noise, compressional waves only, and a single horizontal reflector), the two sets of events-the direct and the reflected arrivals-would be recognized easily on a plot of the recorded data and identified on the basis of their arrival times (fig. III-2). The depth to the reflector could be determined easily as well as the character or shape of the reflected event. This ideal is never realized.

In actual practice we are restricted to one seismometer in the borehole. We can record at only one level at a time, because currently available technology permits only one seismic detector in the hole. Our system usually is constrained further to the measurement of the vertical component of motion or velocity. On occasion, three component detectors have been available, but we then required three data channels to go up a seven-wire cable. In order to use this system and provide in addition for a locking arm motor and a downhole preamplifier, such complexities were introduced in instrumentation with currently available equipment that we usually preferred to restrict our measurements to the vertical component only.

\section{DETECTOR AND RECORDING SYSTEMS}

The well seismometer should have an electromechanical clamping arrangement. Typically, the tool has a locking arm driven by an electric motor that can be activated from the surface. In this arrangement, the arm is driven against the side of the hole with considerable force. A current surge results when the arm engages the hole wall, which gives a positive indication at the surface that the arm is engaged. Five to ten feet of slack are then put in the cable, which suppresses noise that would otherwise travel down a taut cable and interfere with the recording.

Tool options include a spring-driven locking arm, a pressure-sensitive hydrophone, and a three-component detector. Any of these optional devices can be used, but all call for some sort of compromise or trade-off 


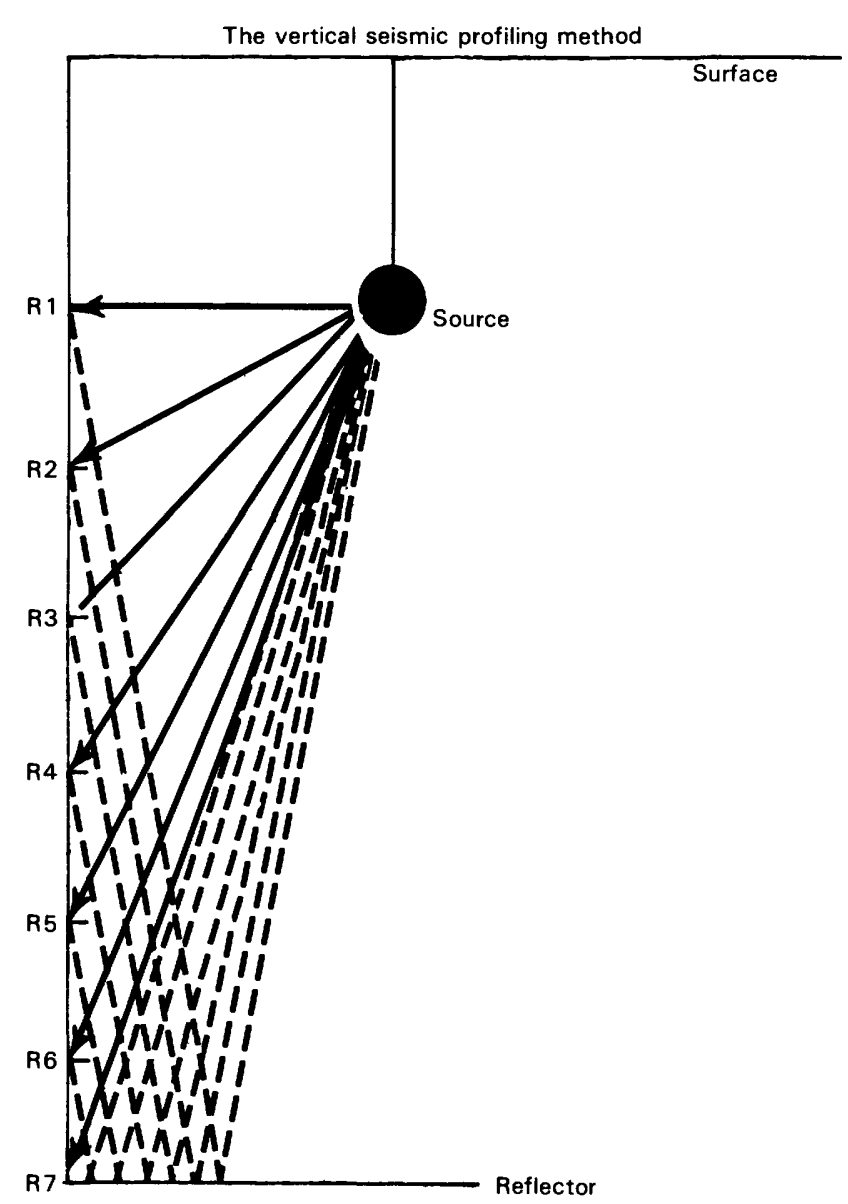

Figure III-1.-Idealized subsurface seismic recording system for vertical seismic profiling. R1-R7 indicate detector locations.

with some other desired tool capability. For example, a three-component detector may preclude the use of a motor-driven locking arm, and a spring-driven locking arm may not keep the tool from slipping or creeping when recording in a cased hole.

All our recordings have been made on digital tape. Digital recordings are essential to us because extensive computer processing is necessary prior to interpretation. The recording system should span the conventional surface seismic-recording frequency band. If the ultimate objectives of the investigation are related to surface seismic exploration, the recording system should be as nearly similar to a surface recording system as possible.

\section{SEISMIC SOURCES}

Explosives, surface air guns, and downhole air guns have been used in the Madison VSP investigation. We now believe that the surface air gun, the Bolt LSS-3, with a 60-cubic-inch chamber, provided the best data ${ }^{2}$.

\footnotetext{
2Trade names are for descriptive purposes only and do not imply endorsement by the U.S. Geological Survey.
}

Explosives, in general, provide high frequencies and a broad band of frequencies. Explosives also yield a high output amplitude. There were two interrelated problems in the use of explosives: nonreproducibility of the source waveform and the relative complexity of the field operation. The source wavelet problem is discussed in the next section.

The complexity of the field operation results from the need to record as many as 400 levels, one level at a time. Even a recording of only one shot per level will require as many as 400 shots. We used relatively small charges (on the order of 1-2 pounds per shot) to preserve source waveform as nearly as possible and to get as many shots as possible from each shothole. Even so, as many as 40 shotholes per well were required. This number necessitated a major shothole drilling operation, which is expensive and time-consuming. In addition, hole caving often prevented us from firing subsequent shots at the same level in a given hole, resulting in source waveform changes. The problem was complicated further by difficulty in removing cap wire from the hole when small charges were used. Water tamping of the holes was difficult to carry out expeditiously during a profiling operation. When we shifted the source to a different hole, additional source waveform changes

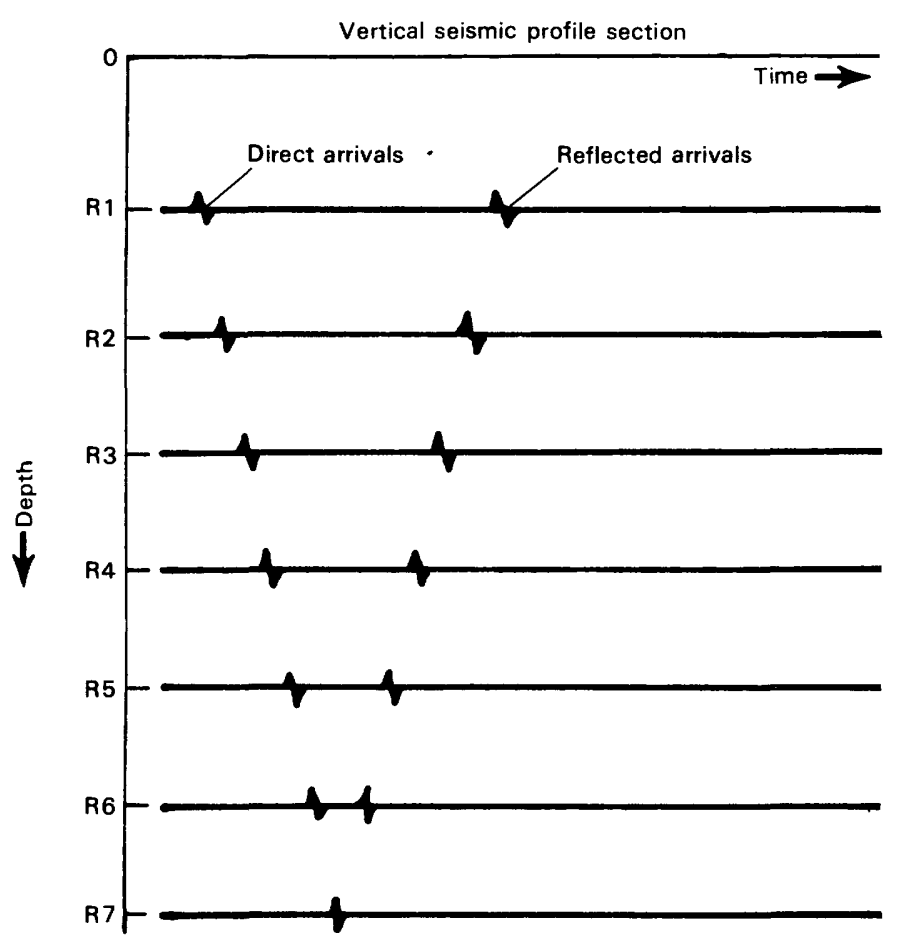

FIGURE III-2.-Idealized plot of data obtained from the vertical seismic profile recording system shown in figure III-1. R1-R7 indicate detector locations. 
resulted. Even cap-wire disposal during shooting was laborious and time consuming. If a source depth of only $100 \mathrm{ft}$ is used for only 400 shoots, this operation still amounts to $40,000 \mathrm{ft}$ of wire to keep picked up.

To expedite the recording operation when using explosives, we tried shooting two or three holes alternately. This technique also proved unsatisfactory and dangerous besides. With several cap leads lying on the ground, misunderstandings arose as to which hole was to be fired next. Because of these and other problems with explosive sources, we eventually resorted to surface air guns almost exclusively.

Surface air guns, of the Bolt LSS 3 type, enabled us to avoid most of the problems with explosives mentioned above. No source holes were required, and the guns could be fired almost indefinitely at one surface location. The lower amplitude was compensated for by firing repeatedly at each level (as many as 25 times) and then compositing these shots. The narrower frequency band, inherent in the surface source, was considered an acceptable trade-off for the convenience of the source. Much of the high frequencies obtained from explosive sources are attenuated quickly in the earth. So the absence of high frequencies in the air-gun source was not nearly so apparent in the air-gun data recorded at depth as we at first supposed it would be.

Two major practical problems with surface air guns were reliable operation in extremely cold (subzero) weather and multiple gun synchronization. We found that skillful, experienced operators were the most essential factor in keeping the air guns going in cold weather. Synchronization was attained by using a multiple trace monitor oscilloscope. Source accelerometer pulses were observed continuously with the oscilloscope, and the firing delays to the sources were adjusted frequently to ensure that the guns fired simultaneously.

\section{A REVIEW OF SOME PROBLEMS ENCOUNTERED IN VERTICAL SEISMIC PROFILING AND SOME POSSIBLE SOLUTIONS}

\section{CHANGES IN SOURCE WAVEFORM}

We mentioned earlier in this section that ideally we would energize the source once and record simultaneously at all levels beneath the source, but equipment constraints restrict us to recording at only one level. In principle we can produce an equivalent set of data by energizing the source many times and recording at all desired levels, one at a time. This data set will be equivalent only if the source waveform remains constant. In practice this is rarely true, especially when using explosives.
Figure III-3 shows a good example of this phenomenon. The source waveforms were monitored with a geophone buried beneath the source, and several of these waveforms are shown on the left side of the illustration.

If we use small explosives, keep the source depth constant, and keep the water tamp constant, we can reduce greatly the variation in source-wave shape. Wuenschell (1976) described a more elaborate procedure for maintaining consistency in source waveform.

In spite of all our efforts, we rarely could reproduce the explosive source waveform more than ten or twelve times. This change in source waveform creates great difficulties, both in processing and in subsequent interpretation. In processing, one of our most effective techniques to enhance desired events is velocity filtering. In our model of the multichannel process, used in the design of the multichannel velocity filter, we assume that the "desired events" have identical wave shapes (but different, though predictable, arrival times) on sets of adjacent traces. If the source waveform changes from level to level, this assumption will not be true, and the quality of our velocity-filtered data will deteriorate. In interpretation, we may see waveform changes from level to level. We cannot infer anything about the physical properties of the medium from these changes unless we know that these changes are not due merely to source waveform changes.

To compensate for source waveform changes, we designed a wavelet-shaping filter. One of the source waveforms, as measured on a monitor detector, is ar-

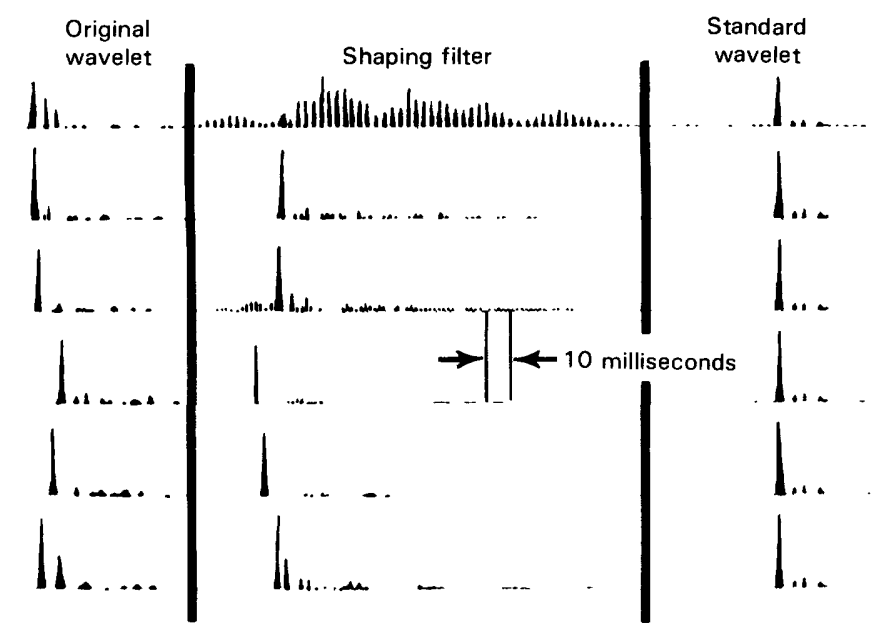

FIGURE III-3.- Source monitor waveforms, shaping filters, and convolution products. Left: source monitor waveforms from the Coronado Collins No. W-1 well, showing variation on successive shots. Center: shaping filters designed to shape source waveform by convolution into an arbitrarily selected standard waveform. Right: convolution products of source waveform and shaping filter; major waveform changes have been removed. Time is in milliseconds. 
bitrarily chosen as a "standard wavelet." Then a shaping filter is designed for every shot at every level that will convert the waveform observed on the monitor detector corresponding to that shot into the standard wavelet. This shaping filter is then applied to the well recording. In this manner we obtained a new set of VSP data approximating what we would have recorded in the field if the source waveform had been constant.

The center part of figure III-3 shows some sample shaping filters, corresponding to the monitor detector recordings shown at the left. On the right of the figure, we see the convolution product of the shaping filter and the source waveform recorded by the monitor.

Even when the surface air gun is used for a seismic source, a change in waveform may occur during shooting. Gradual compaction of the soil beneath the source takes place as the gun is fired repeatedly. This gradual compaction causes a "drift" in the seismic waveform.

In addition, the surface air-gun location often becomes unusable after many firing repetitions and the source must be relocated. This source relocation almost always causes a change in source waveform. Figure III -4 shows an example of a change in source waveform taken from the Pfister Fee No. 1 well in Wyoming. The eighth trace from the bottom has a first arrival that is substantially different from the ones above it. Because that level was the first one recorded after a change in source location, a reasonable assumption is that the change in location caused the change in recorded waveform.

\section{TUBE NOISE}

In this paper we will define tube noise as any seismic disturbance that is confined to the vicinity of the well bore. The most prevalent type of tube noise is thought to be a compressional wave traveling in the fluid column. One mode can travel down the steel casing (casing breaks), another is a surface mode confined to the boundary between the borehole and the surrounding rock, and others may exist also. Tube modes carry little or no information ${ }^{3}$ about the rock lithology and can obscure badly the desired body wave recording. Because tube modes are confined to the well bore, there is no geometrical spreading as is true with the body waves. As a result of no geometrical spreading, their amplitude with respect to body waves can be quite large at great depth.

Figure III-5A shows an example of VSP data in which a tube-wave train, marked with an arrow in the figure, has an amplitude five to ten times greater than the downgoing source pulse. Although this is perhaps an extreme example, such high amplitudes are by no means rare.

\footnotetext{
${ }^{3}$ For an exception to this, see Huang and Hunter (1981a, b).
}

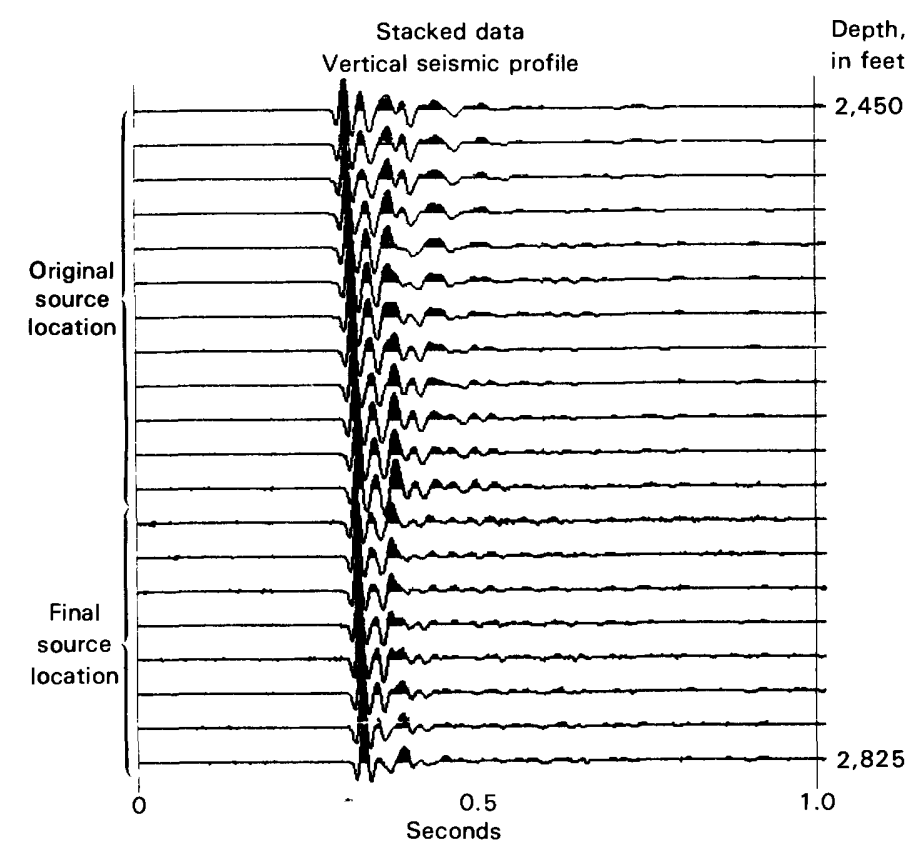

FIGURE III-4.- Stacked, edited vertical seismic profiling data from the Pfister Fee No. 1 well, Wyoming. Note the change in first arrival waveform at the eighth trace from the bottom.

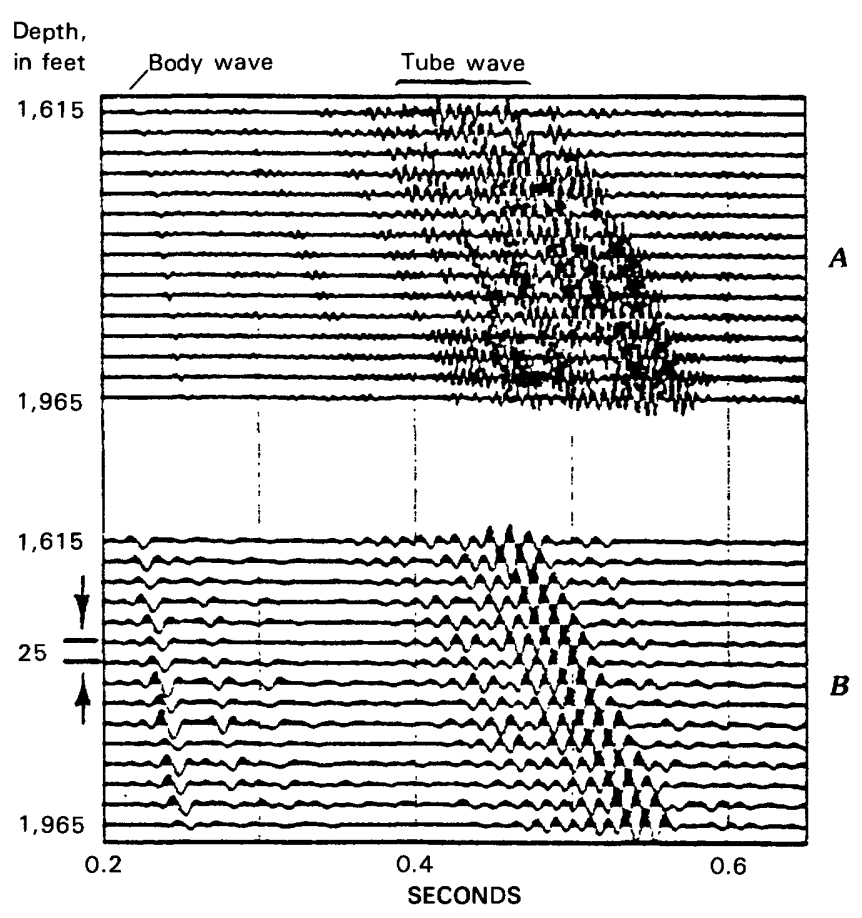

FIGURE III-5.-Composite vertical seismic profile from Coronado Collins No. W-1 well near Newcastle, Wyo., showing pronounced fluid-borne tube waves (arrow). $A$, Composited data; $B$, data from $A$ after bandpass filtering to remove tube waves. 
One of the most effective ways to reduce tube-wave interference is to keep the seismic source away from the wellhead. Our experience indicates that most tubewave disturbances enter the well bore near the surface, either as the result of a direct arrival from the source or, in some instances, as a shallow refraction. Because these events contact the hole in a horizontal or nearhorizontal direction, the noise often can be reduced further by source patterns designed to suppress horizontally traveling energy. As shown in figure III-5B, once the noise has been recorded it often can be partially suppressed by band-pass filtering. Further reduction also can be accomplished by velocity filtering described in chapter IV.

In some instances, the tube-noise amplitude can be so great that it persists in spite of all attempts to remove it. The ultimate resolution of the VSP can be limited by tube-wave noise.

\section{TOOL CREEP}

Always desirable is to put slack on the wire line, after locking the tool in the hole, to reduce cable noise. Sometimes the weight of the tool, combined with part of the weight of the wire line bearing on top of the tool, causes minute slippage. The tool may creep gradually down the hole. This phenomenon can be especially troublesome in casing, although tool creep is by no means confined to cased sections of holes.

Figure III-6 shows an example of the effect of tool creep on the downhole recordings. The lower traces show pronounced creep, whereas the upper traces were recorded while the tool was clamped properly and was stationary.

As with the tube-noise problem, the best solution is to remove the noise in the field instead of recording it. To do this, the clamping system may have to be replaced or overhauled, and this involves a costly round trip for the tool. If the tool is creeping in casing, possibly the tool can be bound to rest at the casing joints. Then the casing joints dictate the spatial sampling interval. This interval may be unacceptably coarse and often is not constant; the length of individual casing sections can vary considerably. Ultimately, recording may have to be done in the presence of creep noise and then suppressed in processing by compositing (stacking) and frequency filtering.

\section{WEAK SIGNAL}

As mentioned earlier, one of the disadvantages of using the surface air gun is its low-amplitude signal output compared with explosives. This problem is especially troublesome at great depth, where geometrical spreading, attenuation, and other transmission effects

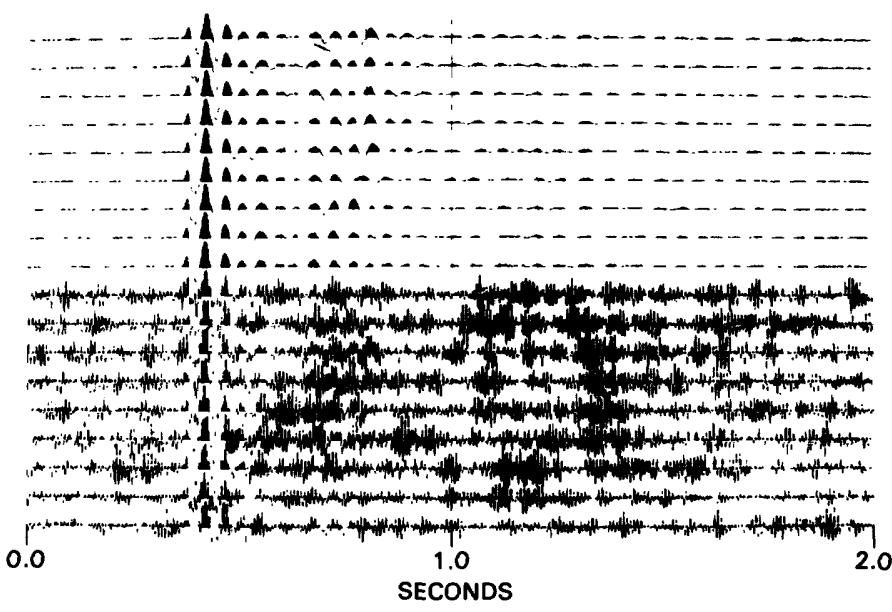

FIGURE III-6.-Example of tool-creep noise observed in the USGS Madison No. 1 well, Crook County, Wyo. Upper traces, tool properly engaged; lower traces show creep.

have substantially reduced the signal amplitude. Figure III-7 illustrates this problem encountered at the $7,000+\mathrm{ft}$ level at the USGS Madison No. 2 near Powderville, Mont. A single air gun was used for the source.

To increase this low signal-to-noise ratio, we composited, or stacked, 20-25 "pops" on each level. The resultant composite is shown in figure III-8. The improvement is dramatic. Note that coherent noise is enhanced just like signal. The low-velocity event at the right of the illustration, marked $\mathrm{T}$ in figure III -8 , is coherent tube noise. Other means must be used to suppress or to eliminate this phenomenon.

An alternative method to accomplish the same result is to increase the source strength by using multiple sources. Provided the sources can be properly synchronized, the signal-to-noise ratio improvement should be directly proportional to the number of sources. In a composite, or stack, the improvement is proportional only to the square root of the number of "pops." For example, the same signal-to-noise ratio improvement theoretically could be achieved by using three sources, or one source and a nine-fold composite.

In order to produce the high signal-to-noise ratio that we require in the VSP work, we frequently used both improvement methods. Ten shots per level with three synchronized sources was a typical field setup.

\section{NEAR-SURFACE REVERBERATION AND GHOSTING}

An implicit assumption usually made in seismic reflection interpretation is that the source generates a single, short-duration pulse. This assumption is rarely 


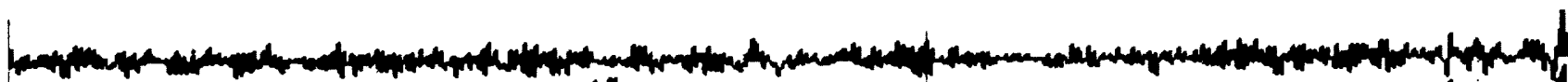

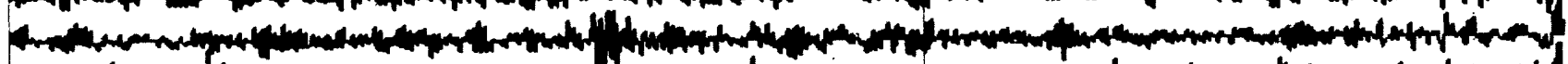

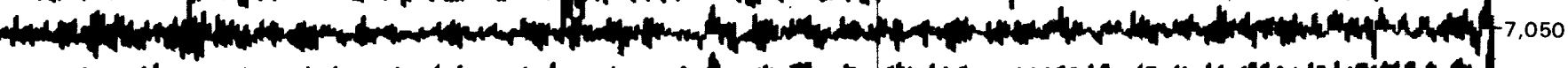

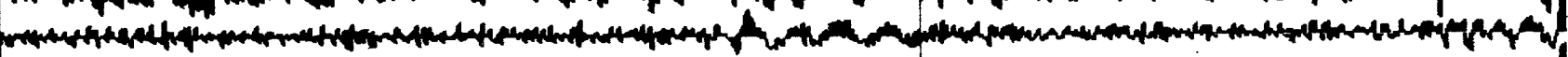
16

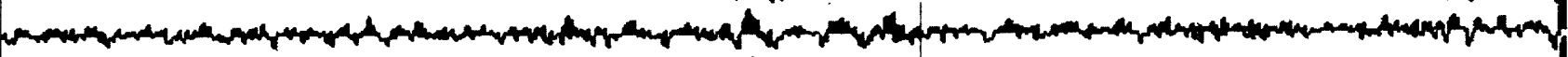

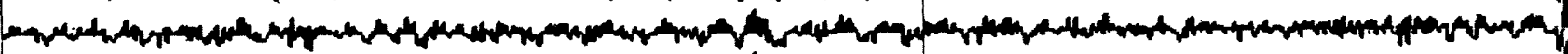

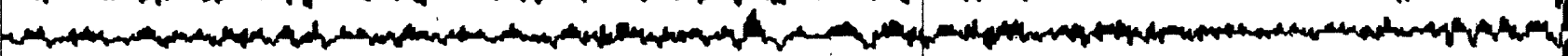

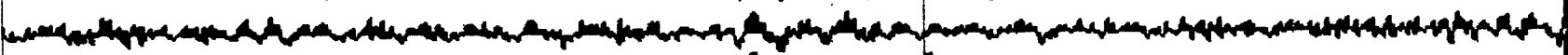
A

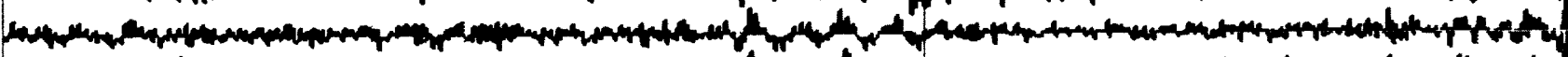

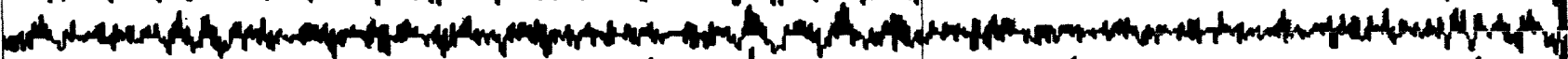

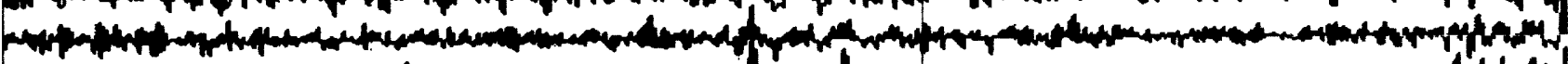

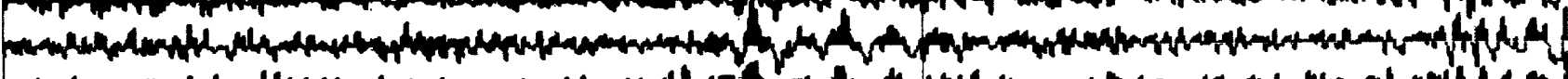

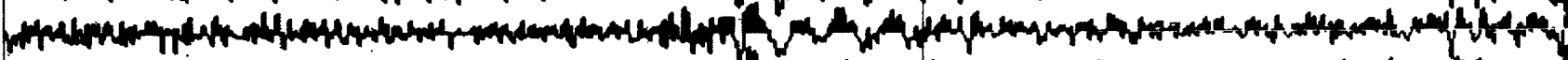

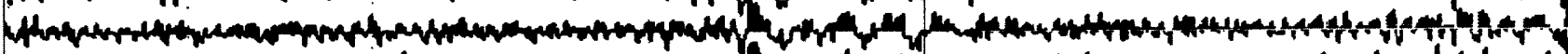

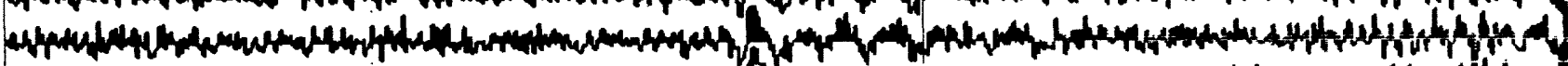

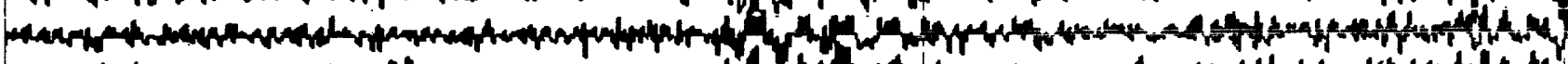

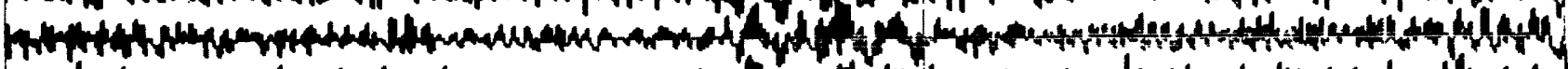

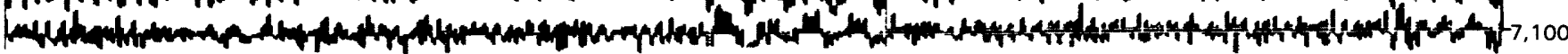

FIGURE III-7.-Specimen recordings at 7,050-7,100 ft in the USGS Madison No. 2 well near Powderville, Custer County, Mont. Note low signal-to-noise ratio, even for the first arrival.

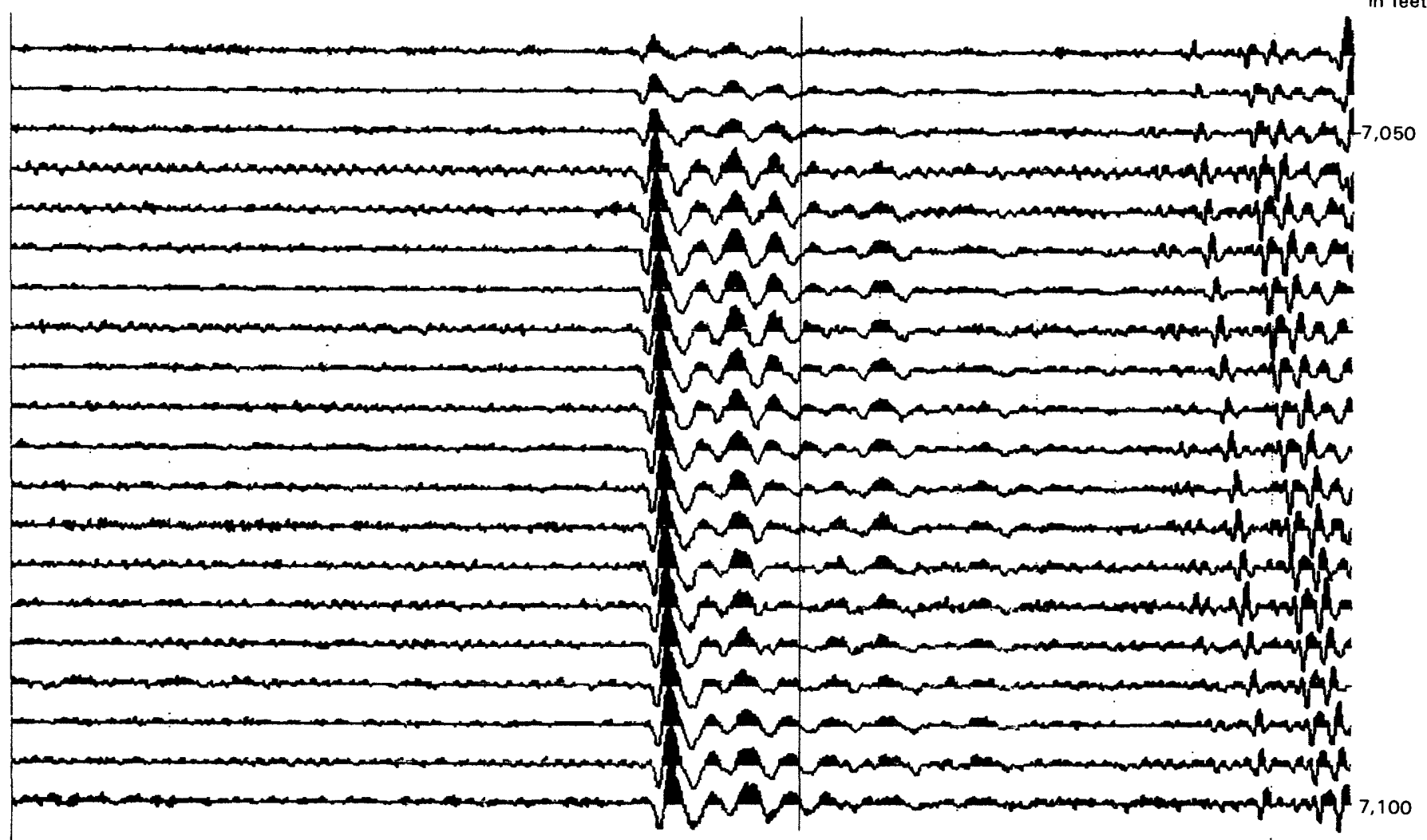

FiguRE III-8. - Sample recordings described in figure III-7, after 20- to 25-fold composite to improve the signal-to-noise ratio. 
true and is demonstrated eloquently in figure III-9, taken from the vertical seismic profile at the Coronado Collins No. W-1 well. The recordings have been timeshifted to aline downward-traveling events.

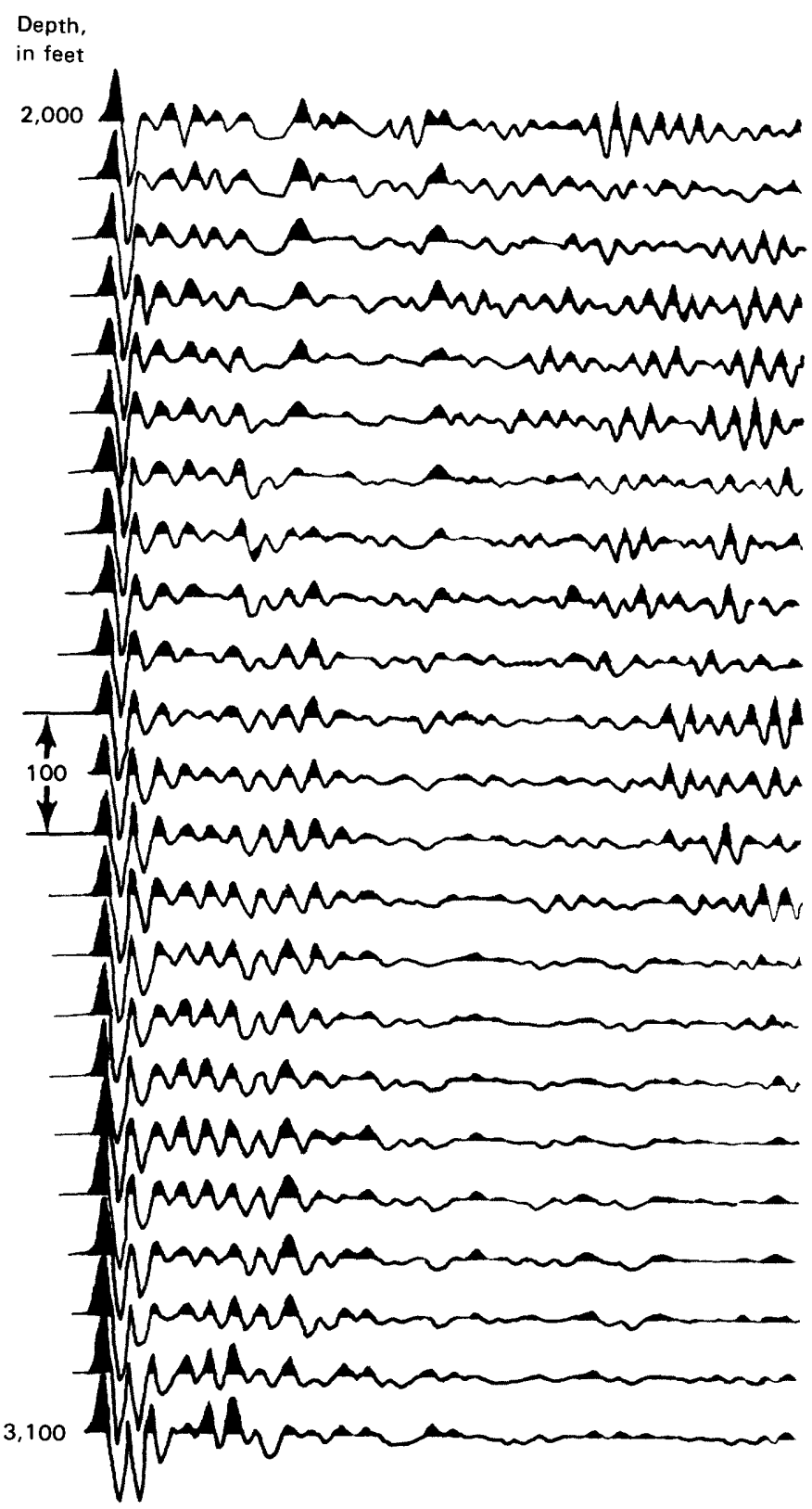

FIGURE III-9.-Vertical seismic profile recordings from Coronado Collins No. W-1 well showing near-surface reverberation effects. Note the long reverberation "tails."

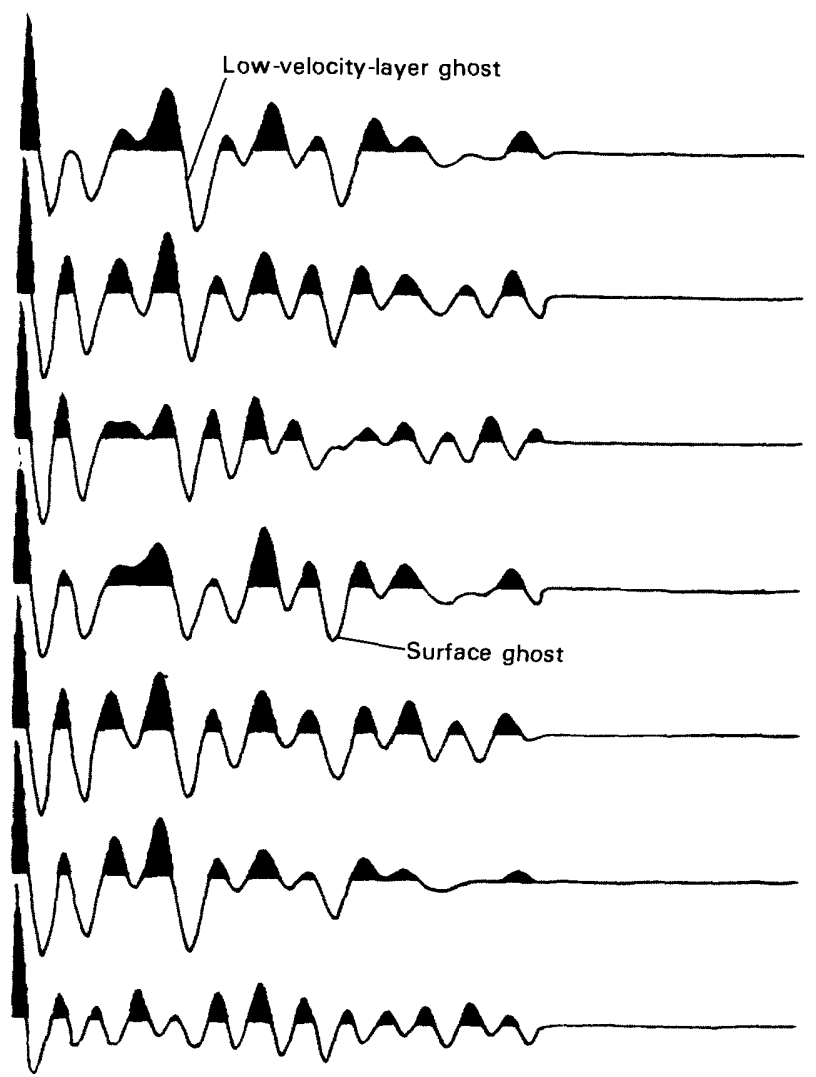

FIGURE III-10.-Autocorrelations of the recordings shown in figure III-9, Coronado Collins No. W-1 well.

The highest amplitude event at all levels is the first arrival from the source, as might have been expected. However, this first arrival has a long "tail" and certainly cannot be considered a short-duration pulse. There also is a second burst of seismic energy about $40 \mathrm{~ms}$ after the first arrival and an additional third arrival. The presence of these later arrivals is confirmed by the data plot in figure III-10, which shows the trace autocorrelation of selected traces from figure III-9. The consistent correlation trough marked "low-velocitylayer ghost" and "surface ghost" correspond to the later arrivals shown in figure III-9. They result from seismic energy that initially traveled upward from the source. Then upward-traveled seismic energy was reflected downward from a low-velocity layer located above the source and from the surface. Additional smaller downward-traveling arrivals seen in figure III-9 are probably the result of near-surface reverberations: energy trapped in the low-velocity-layer region. 


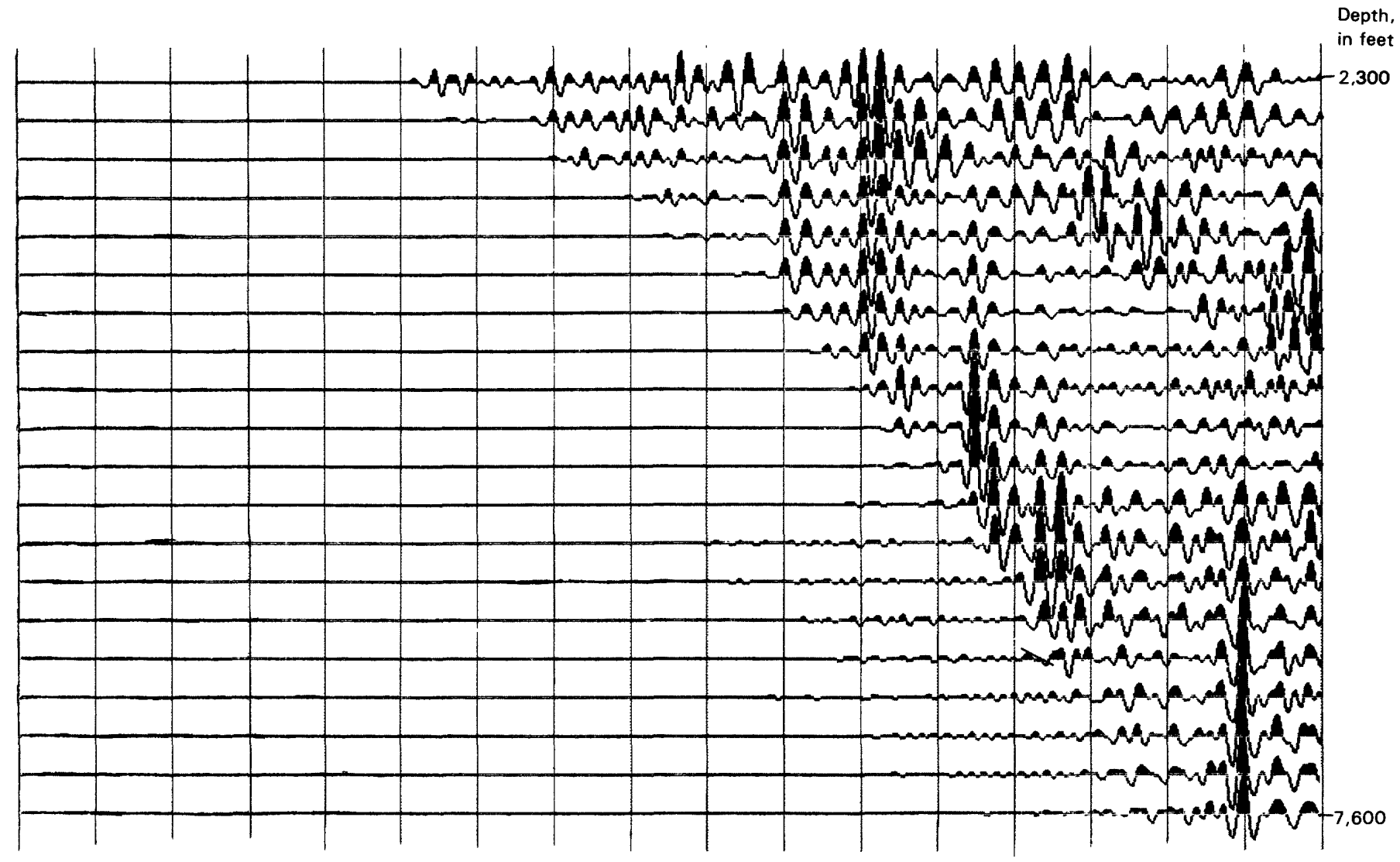

FIGURE III-11.-Velocity filtered vertical seismic profile data from the USGS Madison No. 2 well, showing upward-traveling events. Trace shifted subsequent to filtering to aline the events vertically. (Compare with figure III-8.)

\section{REFLECTIONS OBSCURED BY HIGH-AMPLITUDE DOWNWARD-TRAVELING EVENTS AND NOISE}

The details of velocity filtering are discussed elsewhere in this report, but a brief discussion seems appropriate here because for us the filtering is an essential part of the vertical seismic profiling method. In the preceding figures (III-1 through III-9), few if any upward-traveling (reflected) events are observed. They are present, but much smaller in amplitude than the downward-traveling wave. Because of their small amplitude, upward-traveling events are difficult or impossible to see in the presence of high-amplitude downward-traveling events and random noise.
Velocity filtering is similar in principle to frequency filtering; only events that have a specified apparent velocity are "passed" by the process; all other events are "rejected."

In figure III-11, a set of data from the USGS Madison No. 2 VSP has been velocity-filtered to pass only events that have negative (upward-traveling) velocities. The traces were subsequently time-shifted to vertically aline these seismic events.

The coherent reflections (upward-traveling events) are now readily apparent. In addition, the regions of origin of the reflections are readily determined from the depth scale at the right of the figure. 



\title{
A SEISMIC-STRATIGRAPHIC INVESTIGATION OF THE MADISON AND ASSOCIATED AQUIFERS-APPLICATION TO GROUND-WATER EXPLORATION, POWDER RIVER BASIN, MONTANA-WYOMING
}

\section{PROGESSING OF VERTICAL SEISMIC PROFILING DATA}

\author{
CHAPTER IV
}

By M. W. LEE

\section{CONTENTS}

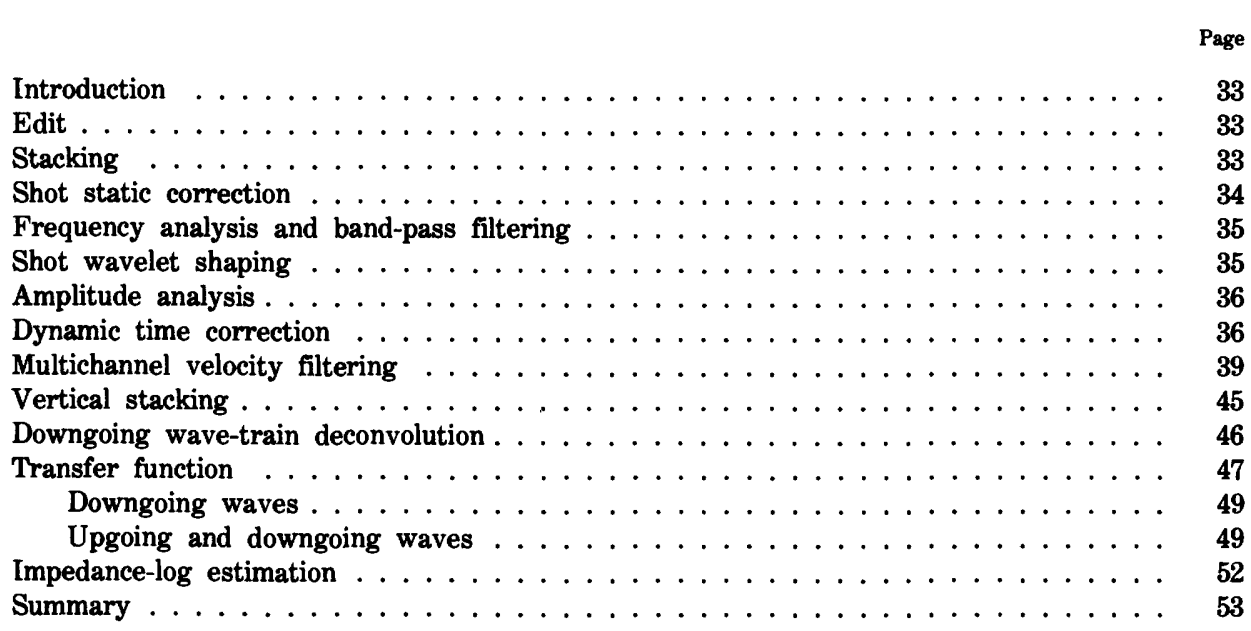

\section{ILLUSTRATIONS}

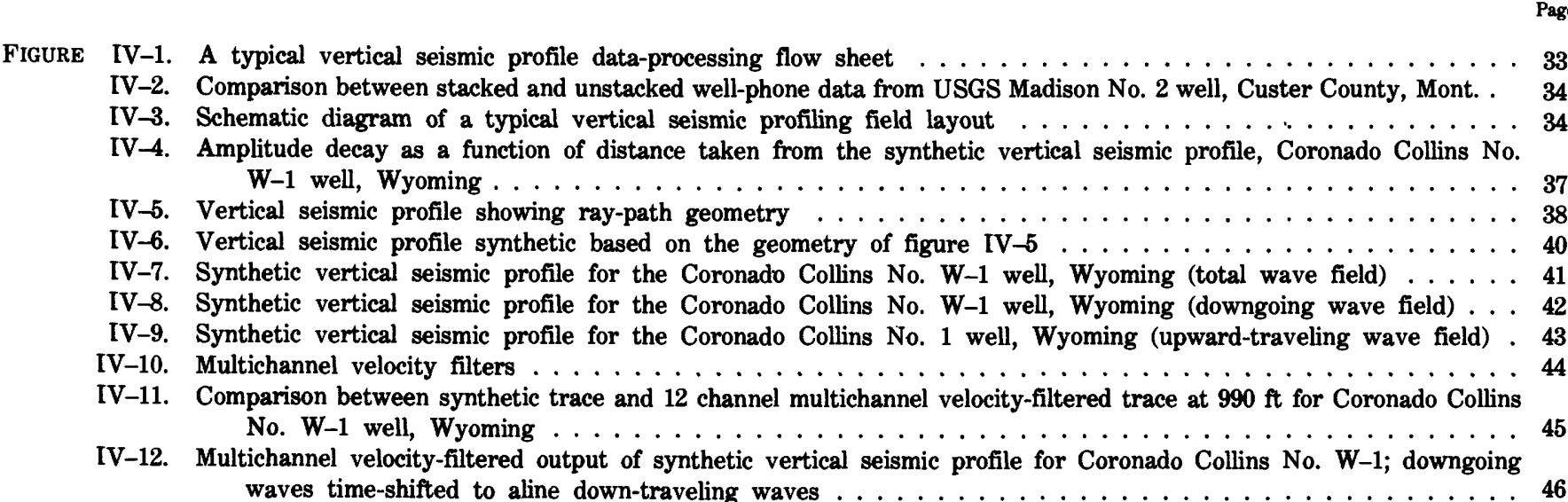


Figure IV-13. Multichannel velocity filtered output of synthetic vertical seismic profile for Coronado Collins No. W-1; upgoing

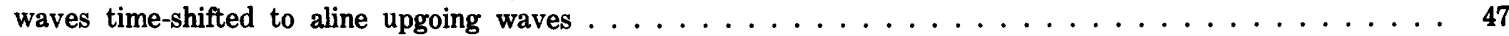

IV-14. Result of applying a downgoing wave-train deconvolution operator to the data shown in figure IV-12 . . . . 48

IV-15. Result of applying a downgoing wave-train deconvolution operator to the data shown in figure IV-13 . . . . 48

IV-16. Normalized amplitude spectra and transfer functions in the frequency domain, downgoing waves, vertical seismic profile, Pfister Fee No. 1 well, Wyoming ........................50

IV-17. Noise-free synthetic seismogram used to test the Kalman filter approach to estimating a transfer function from a

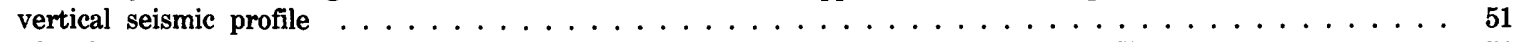

IV-18. Result of using the synthetic seismogram shown in figure IV-17 to test the Kalman filter . . . . . . . 51

IV-19. Estimated transfer function of the top trace of figure IV-15 by Kalman filtering . . . . . . . . . . . . 52

IV-20. Result of estimation of an acoustic impedance log from the reflected wave train of a synthetic vertical seismic profile, Coronado Collins No. W-1 well, Wyoming ........................ 


\section{INTRODUCTION}

Each set of VSP (vertical seismic profile) data is unique. Shooting and recording conditions vary considerably from well to well. At various times, a surface air gun, surface air-gun arrays, explosive charges of different sizes, and downhole air guns were used as the seismic energy source. Different processing techniques have been required for the different surveys. In this section, a general procedure for processing VSP data is presented. The details of the processing steps necessarily differ according to the specific data set. Additional steps sometimes are required, and in individual cases some of the steps mentioned in this section are omitted. A general processing sequence is sketched in figure IV-1.

\section{EDIT}

Every recording is plotted individually for an initial quality check. The time-break channel is plotted adjacent to the downhole recording. Timing errors, if any, are corrected-trace by trace-to an accuracy of one sampling period. Noisy and other obviously unsuitable recordings are eliminated from the data set at this stage. This editing process is subjective and may be repeated several times.

\section{STACKING}

Surface sources are notoriously weak. Often the source must be energized several times at each detector level, and then all recordings at a given level must be combined or stacked. A stack fold of 5-30 was used at various locations and depths, depending upon the signal-to-noise ratio. If the noise background is uncorrelated (that is, white), then the signal-to-noise ratio improvement is approximately $\sqrt{ } N$ where $N$ is the stack fold. In spite of the need for multiple shooting, surface sources generally proved more satisfactory in our investigations, primarily because of the nearly identical waveforms generated by the surface source. The surface source makes stacking, as well as other data manipulations, particularly effective.

Figure IV-2A shows a set of original VSP data after edit, acquired at USGS Madison No. 2 well, near Powderville, Mont., at a well-detector depth of about 7,100 $\mathrm{ft}$. Figure IV-2B shows stacked data. The improvement in signal-to-random-noise ratio is substantial. Tube noise is coherent and is, therefore, enhanced just like the signal. An enhanced tube-noise wave train can be seen at $1.6 \mathrm{~s}$ (second) on figure IV-2B.

When explosives are used, the recordings rarely are stacked. The explosive source strength generally is ad-

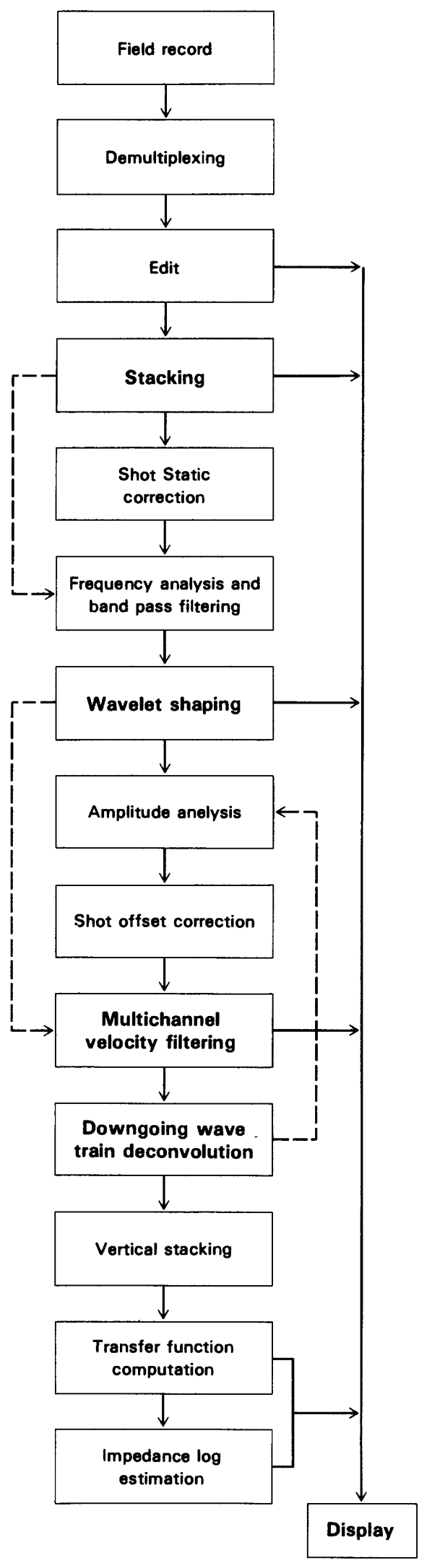

Figure IV-1.-A typical vertical seismic profile data processing flow sheet. 

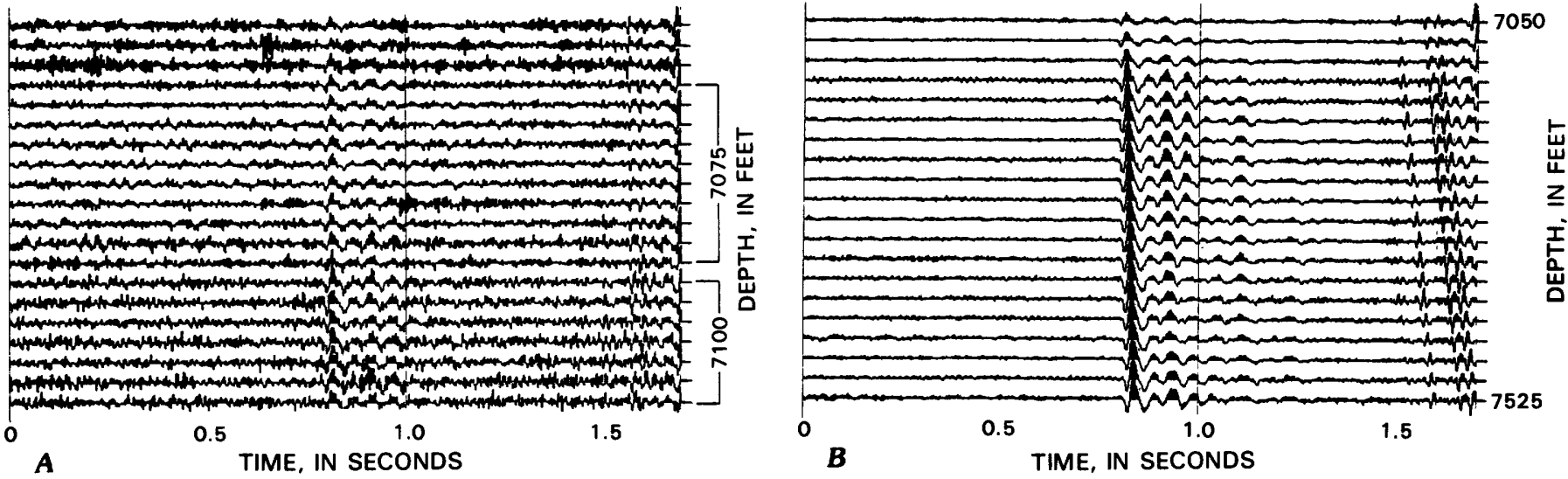

FIGURE IV-2.-Comparison between stacked and unstacked well-phone data from USGS Madison No. 2 well, Custer County, Mont. A, Unstacked; $B$, stacked.

equate, making repeated shots unnecessary. The source waveform obtained using explosives may vary considerably from shot to shot, and explosive sources may reduce the effectiveness of stacking if it is attempted.

\section{SHOT STATIC CORRECTION}

When buried seismic sources (such as explosives, downhole air guns) are used, the source depth may change significantly during the course of the survey. Hole caving and hole fatigue may require use of a different source depth or of a different hole, which usually causes a change in recorded arrival times due to changed source-receiver geometry.

Figure IV -3 shows a schematic diagram for VSP shooting, where:

$l=$ shot offset distance from the center of the well,

$d_{i}=$ shot depth of the shot location $i$,

$T_{i}=$ direct arrival time at the well phone from shot location $i$, and

$H=$ depth of the well phone.

Let shot 1 be the reference shot. We shall correct all other shots to this reference. The direct arrival time from shot $i$ to the well phone is:

$$
T_{i}=\sqrt{\frac{l^{2}+\left(H-d_{i}\right)^{2}}{V}}
$$

where $V$ is the average velocity in the region between the source and the receiver. Then, the correction time for shot 2 will be, with $d_{2}=d_{1}+\Delta d$ :

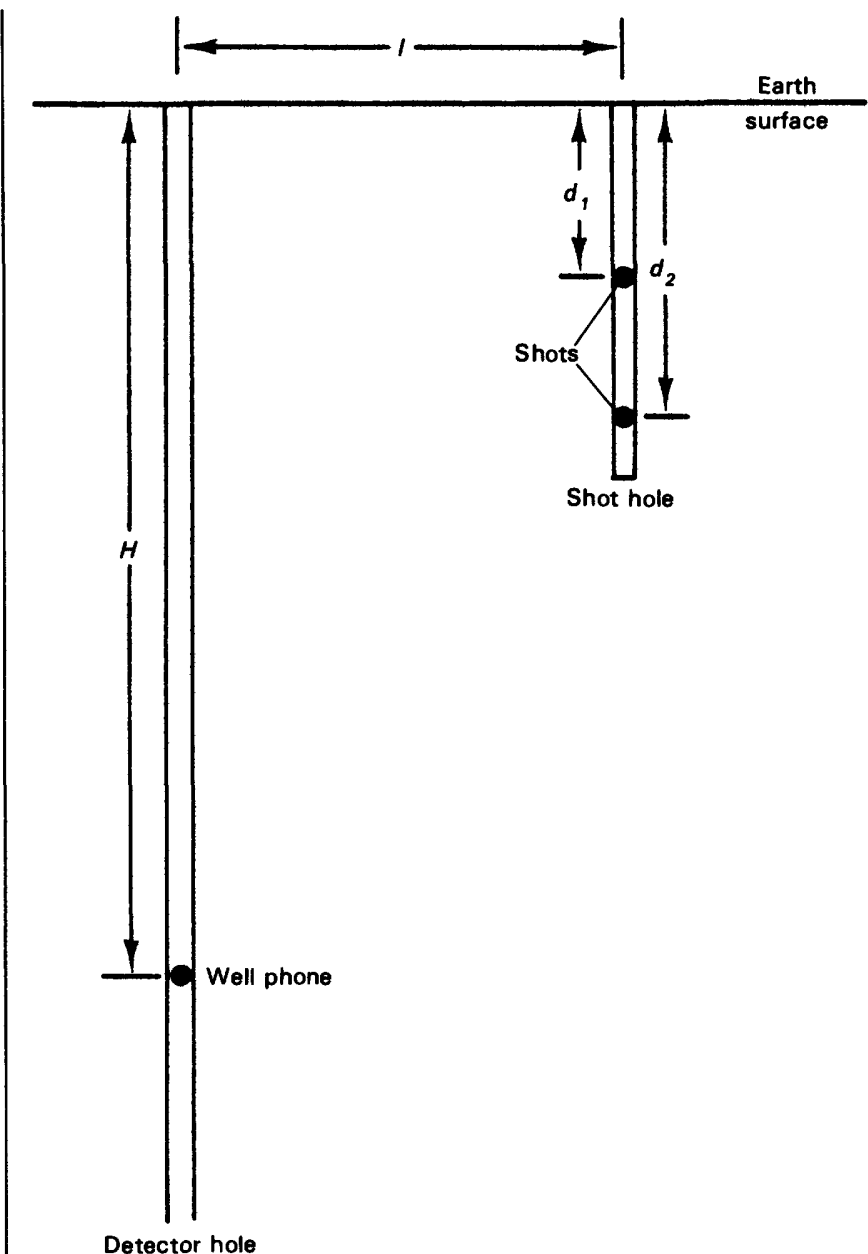

FIGURE IV-3.-Schematic diagram of a typical vertical seismic profiling field layout. $l$, Shot offset distance from center of well; $H$, depth of well phone; $d$, shot depth. 
$\Delta T \stackrel{\Delta}{=} T_{2}-T_{1}=T_{1}\left\{\sqrt{1+\frac{\Delta d\left(\Delta d-2 H+2 d_{1}\right)}{l^{2}+\left(H-d_{1}\right)^{2}}}-1\right\}$.

Equation (IV-1) can be used for the shot static correction.

If $H>>l$ and $H>d_{i}$, then using a Taylor series expansion we can show that:

$$
\Delta T=\frac{-\Delta d}{V} .
$$

Also, when $l=0$,

$$
\Delta T=\frac{-\Delta d}{V}
$$

Equation IV-2 ignores all the horizontal components of the ray paths. Normally, equation IV-1 is used for shallow well-phone locations and equation IV-2 is used for deep well-phone locations.

Figure IV-3 shows that the formulae apply, when $l=0$, both to direct arrivals and primary reflections that originate below both sources. "Ghost" arrivals (wherein the energy was first reflected from the surface) and ghost reflections require the opposite correction; both corrections cannot be made on one recording. Because ghost events are undesirable, the deterioration of ghost events by stacking with the opposite correction is not a fatal flaw in the processing procedure. However, the ghosting effect sometimes can be dealt with better if a deghosting filter, or operator, is applied prior to stacking the static corrected data ${ }^{4}$. The best results are obtained when the variation in source depth is kept to a minimum.

Surface sources have the advantage that the shot static correction is small or even negligible.

\section{FREQUENCY ANALYSIS AND BAND-PASS FILTERING}

Additional signal-to-noise ratio improvement often can be obtained by band-pass filtering. Two significant sources of noise that can be suppressed in this manner are tube noise (which is coherent) and random background noise.

Spectral analysis is required to determine signal, coherent noise, and random-noise frequency bands. If

\footnotetext{
${ }^{4}$ Strictly speaking, an upgoing (reflected event) wave does not have the same shot static correction as does the direct arrival, but in the deep part of the hole, the error is small.
}

the tube-noise (coherent) frequency band is outside or partially outside the signal frequency band, band-pass filtering is highly effective in suppressing tube noise. To partially suppress random noise and tube noise that is partially in the signal frequency band, the best solution is to design the filter to pass only the signal frequency band. This procedure is not as effective as those in which the signal and noise are well separated in frequency. Neverthelesss, this procedure still can produce a substantial signal-to-noise improvement.

\section{SHOT WAVELET SHAPING}

Ideally, the source would be energized only once and recorded at all depth levels simultaneously. Instrument constraints usually allow only a single detector in the borehole and we can, therefore, record only one depth level at a time. If the source always emitted an identical waveform, even with this equipment limitation, a set of data would be obtained identical to that which would have been obtained in the ideal case. Much processing and interpretation is based on the assumption that the source wavelet is identical for all recordings at all depth levels, but the assumption rarely is valid. In fact, the source waveform almost always is different for every recording episode. When explosives are used, the change is especially great.

One initial processing step is to filter the data in such a way as to create the data set that would have been obtained if the source waveform had been identical on every shot. We can do this by using the information recorded from a source monitor geophone located near the source. The source monitor may not yield a true record of the source waveform because the medium in the neighborhood of the source and source monitor usually is heterogeneous. However, we can get a good measurement of the change in source waveform by using the source monitor. So, we arbitrarily choose one source monitor waveform recording and call it the standard wavelet or standard shot waveform. The monitor waveform corresponding to each recording is then examined, and an individual filter is designed that will convert each individual monitor waveform into the standard wavelet. This filter is applied to the appropriate downhole recording, and the result is regarded as the recording that would have been obtained had the seismic source been identical for every shot.

Let $P_{s}(t)$ be the standard wavelet and $P_{i}(t)$ be the individual shot waveform recorded by the monitor for a particular shot. Then we can compute a filter $f(t)$ to convert $P_{i}(t)$ into $P_{s}(t)$ using a least-squares shaping filter. Two filter parameters also must be selected: fil- 
ter length and filter delay. These parameters usually are chosen by trial and error, using samples of the complete data set. Once chosen, the same length and delay usually are used for all the data.

Figure III-3 shows some results of this operation. These data come from the vertical seismic profile of the Coronado Collins No. W-1 well, Wyoming. The source was dynamite. In this figure, the left section shows the original input shot wavelet, the center section shows the computed shaping filters, and the right section shows the convolution of original wavelet with shaping filter. This figure demonstrates how effective the process is.

The standard waveform in this particular example is an uphole waveform, not the true downgoing waveform. In this particular example, the uphole geophone was used as the monitor geophone. The results obtained were adequate, but our experience indicates that a detector buried in the earth, well beneath the source, generally gives better results.

\section{AMPLITUDE ANALYSIS}

The amplitude of the seismic events varies greatly with time and well-detector location, often by as much as $1,000,000$ to 1 . Geometrical spreading, loss in downward-traveling energy due to upward reflection, intrabed multiple effects, and inelastic attenuation all contribute to this observed amplitude decay. Only geometrical spreading is frequency-independent. Further, geometrical spreading is related only remotely to the subsurface rock properties we wish to measure. Therefore, removing the geometrical spreading effect is desirable, at least approximately, before making a geologic interpretation.

Also desirable is to make some additional compensation for nongeometric effects. To determine the appropriate amplitude compensation, the amplitude of the first arrival is measured at every level, and these amplitudes are fitted by least squares to the following functions:

$$
\frac{c e^{-\alpha R}}{R} \text { or } C R^{n}
$$

where

$$
\begin{aligned}
& R=\text { distance from the source, or arrival time, and } \\
& c, n, \alpha \text { are constants. }
\end{aligned}
$$

The quantity $R$ helps to account for geometrical spreading; $n$ and $\alpha$ help to compensate for transmission losses and attenuation; and $c$ is an arbitrary constant, or scale factor. Because all effects except geometrical spreading are frequency-dependent, to some extent, $n$ and $\alpha$ may vary with the frequency range of the data.

Figure IV $-4 A$ shows amplitude versus distance in the frequency range $10 / 20-100 / 125 \mathrm{~Hz}$ (hertz), and figure IV $-4 B$ shows the same in the frequency range $10 / 20-50 / 75 \mathrm{~Hz}$. In these figures, the heavy straight line represents the least-squares curve, and the light line represents the computed peak amplitude of the synthetic VSP data. Obviously, this amplitude decay is frequency-dependent.

One difficulty in determining a gain compensation function for VSP data comes from the presence of coherent tube noise. Because the amplitude decay characteristics of body waves (signal) are quite different from those of the tube noise, we may produce enormous tube-noise amplitude in the gain-compensated data. Near-surface reverberations also interfere with amplitude analysis because their amplitude does not fall off with time at the same rate as other events. Thus, there is a subjective element in amplitude decay analysis and compensation. The final amplitude compensation depends on the frequency, tube noise, and the kind of information we hope to derive from the data.

\section{DYNAMIC TIME CORRECTION}

We assume that the ray paths are vertical in much of our processing and interpretation. This assumption is almost always true especially at great depth in the ground. It is strictly correct only when the source is coincident with the wellhead and the well bore is normal to the sedimentary layers (zero dip). We cannot place the source at the wellhead because (1) the ground conditions near the well site usually are unsuitable, (2) the amplitude of the tube noise would be too great, (3) the source should be located in a good shooting medium, and (4) damage to the well might result. In normal VSP operations, our offset distance has been $200-500 \mathrm{ft}$.

The non-zero shot offset distance affects arrival times, amplitude, and waveform of the early seismic events rather dramatically. We did not attempt to correct the waveforms and amplitudes due to the non-norral incidence ray paths. 


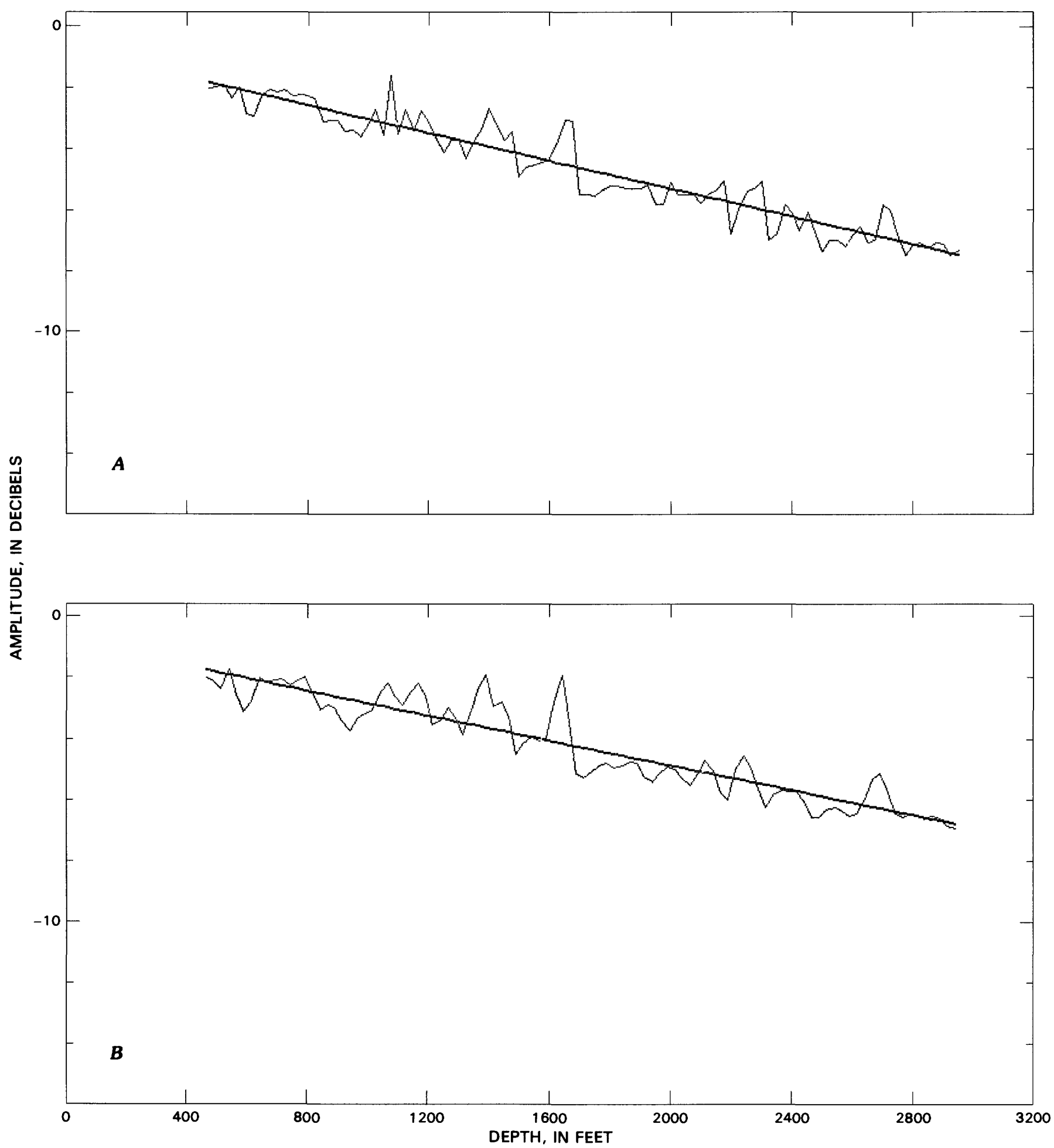

FIGURE IV-4.-Amplitude decay as a function of distance taken from the synthetic vertical seismic profile, Coronado Collins No. W-1 well, Wyoming. $A$, Frequency range of $10 / 20-100 / 125 \mathrm{~Hz} ; B$, frequency range of $10 / 20-50 / 75 \mathrm{~Hz}$. 
Upgoing and downgoing seismic events that occur at the same time on a VSP trace have a different shotoffset correction because of the variation of the velocity of the medium. However, in the following derivation of shot-offset correction time, we shall assume that the correction is identical.

The ray-path geometry used in the dynamic time correction is illustrated in figure IV -5 where:

$l=$ shot offset distance,

$H_{1}, H_{3}=$ well-phone depths, and

$\mathrm{H}_{2}=$ a reflector depth.

Using this geometry, a dynamic time correction can be made that produces a new data set. The new data set is approximately that which would have been recorded had the source been coincident with the wellhead. The correction is derived as follows:

Let

$$
\begin{gathered}
T_{u}=\sqrt{\frac{\left(2 H_{2}-H_{1}\right)^{2}+l^{2}}{V_{2}}} \\
\bar{T}_{u}=\frac{2 H_{2}-H_{1}}{V_{2}} \\
\bar{T}_{D}=\frac{\sqrt{H_{3}^{2}+l^{2}}}{V_{3}} \\
\bar{T}_{D}=\frac{H_{3}}{V_{3}}
\end{gathered}
$$

where $V_{i}$ is the average velocity determined from the first arrivaltimes up to $i$-th well-phone location, $T_{u}$ is the arrival time of a reflected event at the detector located at $H_{1}$ (upward-traveling event), $\bar{T}_{u}$ is the corresponding arrival time with zero source offset, $T_{D}$ is the travel time from the source to a detector located at $H_{3}$, and $\bar{T}_{D}$ is the corresponding arrival time for a zerosource offset.

Then,

$$
T_{u}^{2}-\bar{T}_{u}^{2}=\frac{l^{2}}{V_{2}^{2}}
$$

Therefore,

$$
\Delta T_{u} \triangleq\left(T_{u}-\bar{T}_{u}\right)=\frac{l^{2}}{\left(T_{u}+\bar{T}_{u}\right) V_{2}^{2}}
$$

Equation IV -3 is the shot-offset correction time at wellphone location $H_{1}$ for the upgoing wave from the reflector $\mathrm{H}_{2}$.

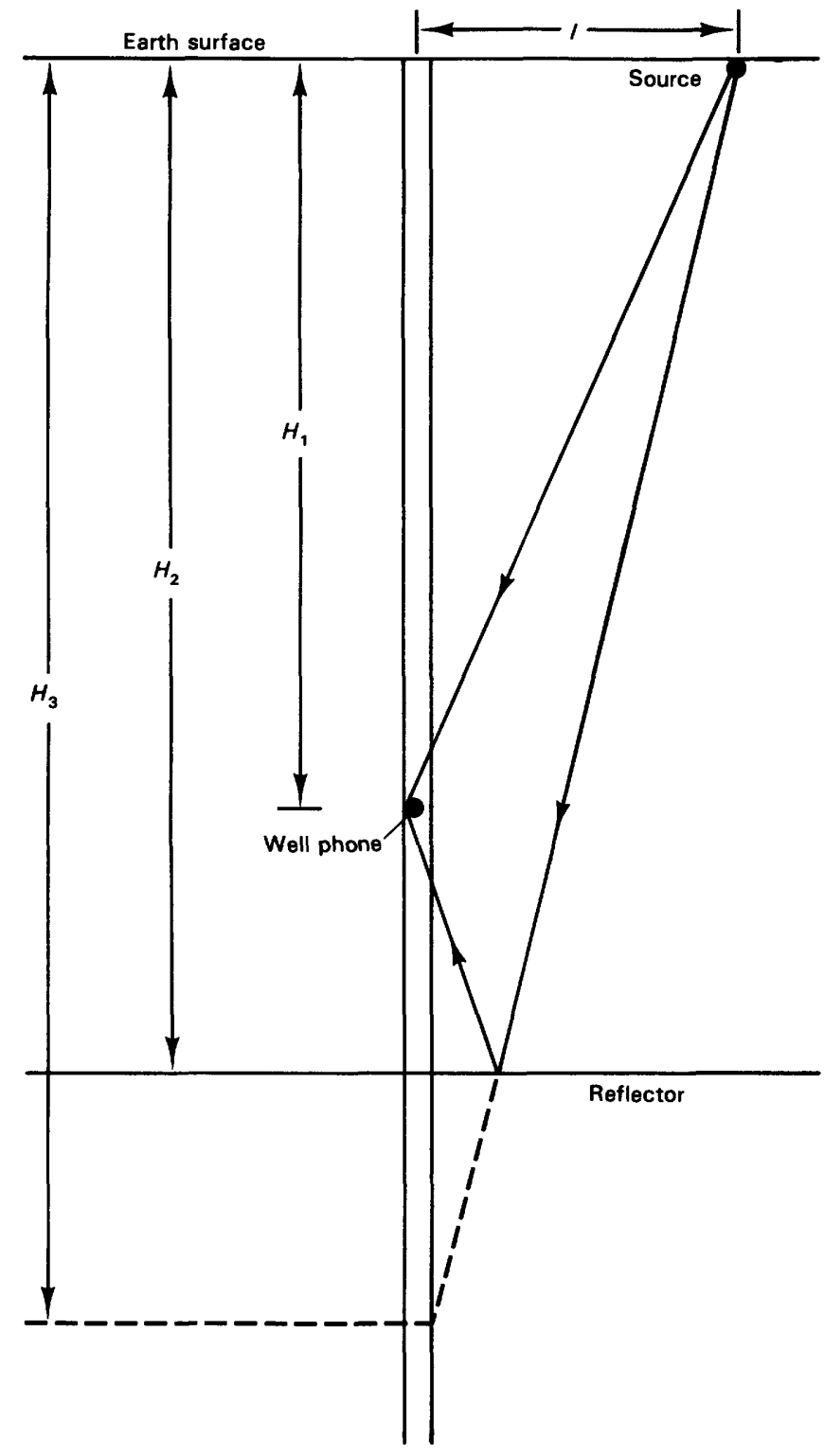

FIGURE IV-5.-Vertical seismic profile ray-path geometry. $l$, Shot offset distance; $H_{1} H_{3}$, well-phone depths; $H_{2}$, reflector depth.

Similarly,

$$
\Delta T_{D} \stackrel{\Delta}{=} T_{D}-\bar{T}_{D}=\frac{l^{2}}{\left(T_{D}+T_{D}\right) V_{3}^{2}}
$$

Equation IV-4 is the shot-offset correction time for the well phone located at a depth $H_{3}$ for the direct arrival from the source.

Assume that $T_{u}=T_{D}$. Then, as mentioned before:

$$
\Delta T_{u}=\Delta T_{D}
$$


Therefore, the general equation for shot-offset correction is:

$$
\Delta T_{u}(t)=\Delta T_{D}=\frac{l^{2}}{\left[t+\frac{H}{V(t)}\right] V^{2}(t)}
$$

where:

$$
\Delta T_{N}(t)=\text { shot-offset correction at time } t \text {, and }
$$$$
V(t)=\text { average velocity up to time } t \text {. }
$$

We can compute $V(t)$ using the first arrivals of the VSP data with known $H$ and $l$.

The following shot-offset correction formula is a sufficiently good approximation for events arriving after the first arrivals deep in the well:

$$
\Delta T_{n}(t) \cong \frac{l^{2}}{2 t V_{\max }^{2}}
$$

where $V_{\max }$ is the average velocity computed using the first arrival time of the deepest well phone.

Notice that when $H>>l, T_{N}(t) \rightarrow 0$, and

$$
t \rightarrow \infty, \Delta T_{N}(t) \rightarrow 0 \text {. }
$$

This effect is similar to the normal moveout correction for the conventional surface seismic shooting due to non-zero offset geophone location.

Using a simple one-layered half-space model (fig. IV-5), we applied this formula to the non-zero shot offset VSP. To illustrate the principle, we have calculated a set of synthetic VSP's based on the geometry of figure IV-5. In the synthetic $l=200 \mathrm{ft}$, well-geophone locations go from $300 \mathrm{ft}$ to $1,200 \mathrm{ft}$ at $100-\mathrm{ft}$ intervals, and the medium velocity is $5 \mathrm{ft} / \mathrm{ms}$ (feet per millisecond).

Figure IV-6A shows the zero offset VSP using a $5 / 10-100 / 125 \mathrm{~Hz}$ zero-phase band-pass filter and figure IV $-6 B$ shows the 200 -ft offset version using the same wavelet. Figure IV $-6 C$ shows the result of the application of equation IV-5 to figure IV-6B. In all three figures, the events up to time $240 \mathrm{~ms}$ are the first arrivals from the source, and events later than $260 \mathrm{~ms}$ represent the reflected events. By comparing figure IV-6A to figure IV-6C, we can also see that the arrival times have been corrected quite accurately, but we can also see the broadening of the wavelets for the earlier events. This effect is exactly the same as normal moveout correction for the conventional surface seismic shooting due to non-zero offset geophone location.

This correction is important in separating upgoing and downgoing waves using multichannel velocity filtering, especially for the shallow well-phone locations.

\section{MULTICHANNEL VELOCITY FILTERING}

In conventional seismic exploration, all the events of interest recorded on the surface seismograms are upgoing waves (reflected events). But in vertical seismic profiling, recorded events consist of a superposition of the downgoing and upgoing wave trains. To identify reflected events, we often need to separate the upgoing and downgoing waves. The optimum multichannel velocity filter is an effective way of accomplishing this separation. It uses the apparent velocity of coherent events on a set of adjacent recordings, or traces, to distinguish between the desired events (coherent events with the prescribed apparent velocity) and unwanted events (incoherent events and coherent events with the "wrong" apparent velocity).

Many papers describe velocity filtering (Embree and others, 1963; Foster and others, 1964; Sengbush and Foster, 1968). Sengbush and Foster's optimum multichannel velocity-filtering scheme was used in the examples shown here.

To test the velocity-filtering scheme, we generated synthetic vertical seismic profiles for the Coronado Collins well No. W-1, Wyoming, from the sonic log. In generating a synthetic VSP, we can compute the upgoing and downgoing waves separately. The sum of these two is the total wave field (similar to the field-recorded VSP).

Figures IV-7, IV-8, and IV-9 show the total, downgoing, and the upgoing waves, respectively. In all synthetic computation, we used a depth increment of 25 $\mathrm{ft}$ starting from $465 \mathrm{ft}$. The source was assumed to be at a depth of $175 \mathrm{ft}$, and the initial shot waveform was a zero-phase, band-pass (10/20-100/125 Hz) wavelet.

Designing multichannel velocity filters for this synthetic VSP is not a simple matter. The wave shape is changing with time and the signal-to-noise ratio is different for upgoing and downgoing waves. To compensate for these problems, we should develop multichannel time-varying and space-varying velocity-filtering techniques. This development would be possible, but its application would be complicated and would take a great deal of time in processing. So, time- and spaceinvariant, constant signal-to-noise ratio filters usually are applied. 


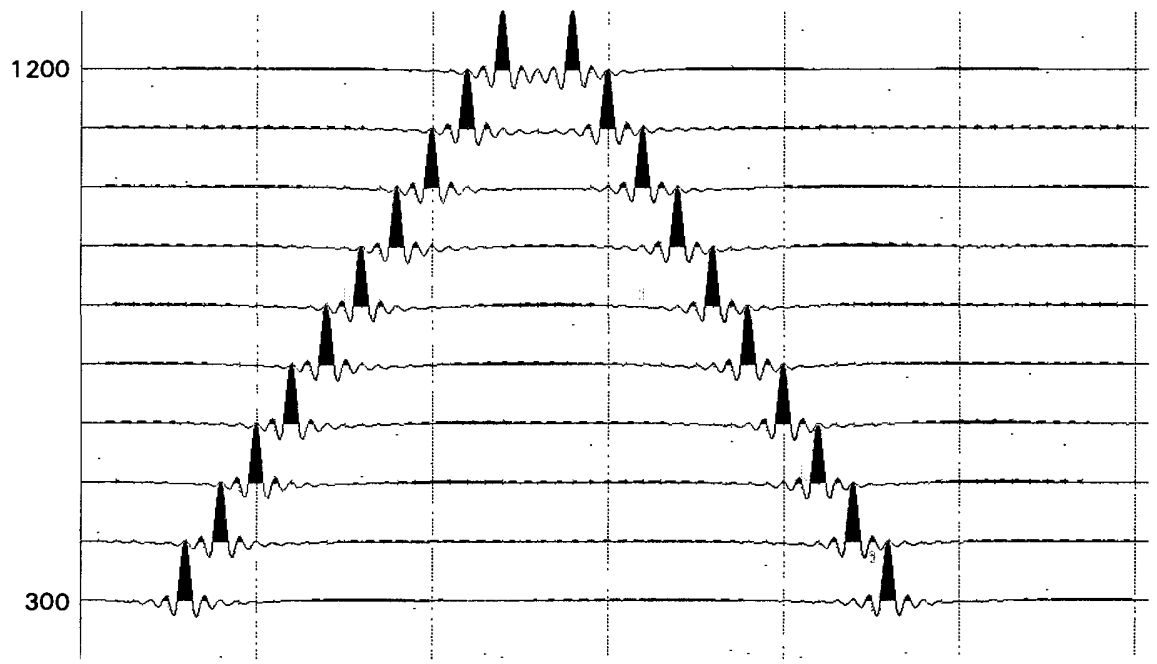

$\boldsymbol{A}$

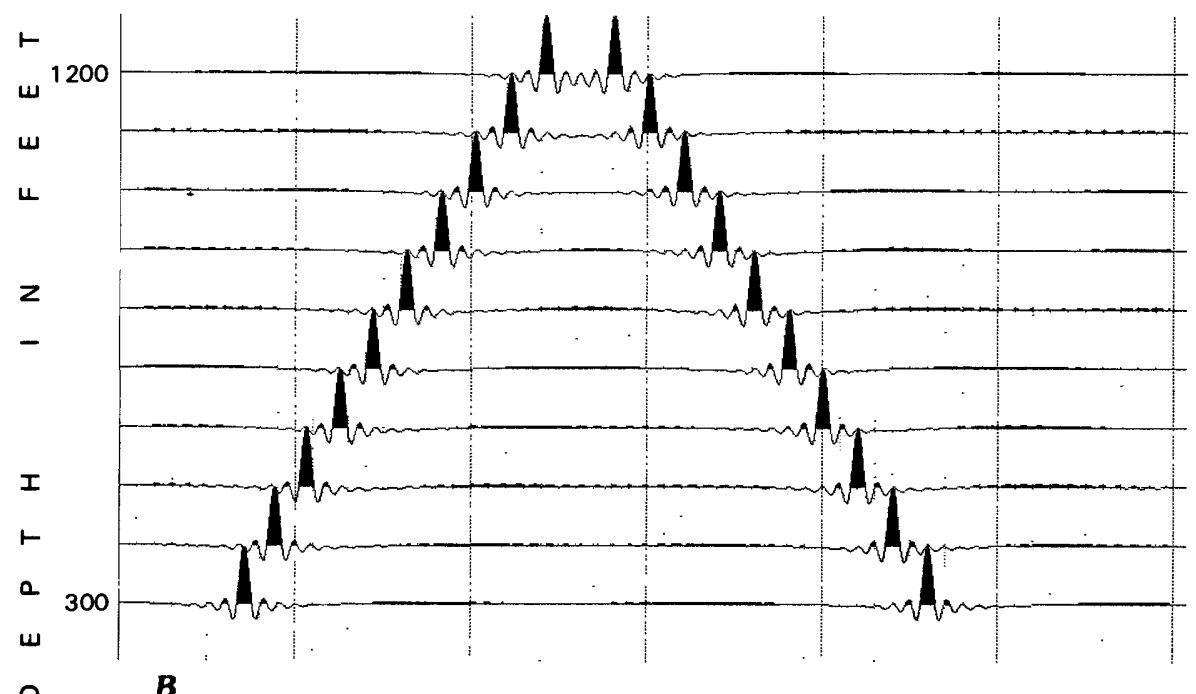

o

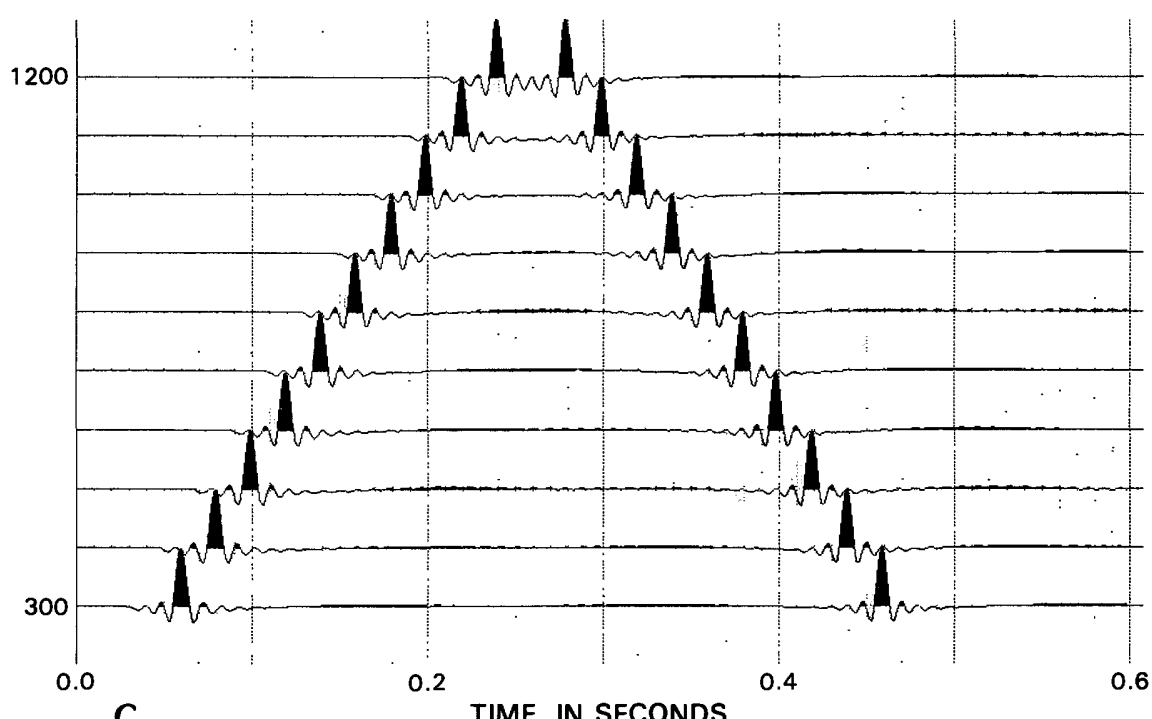

FigURE IV-6.-Synthetic vertical seismic profile based on the geometry of figure IV-5. $A$, Zero source offset data; $B$, source offset of $200 \mathrm{ft}$; $C$, dynamic time correction of figure IV- $6 B$ to compensate non-zero offset. 


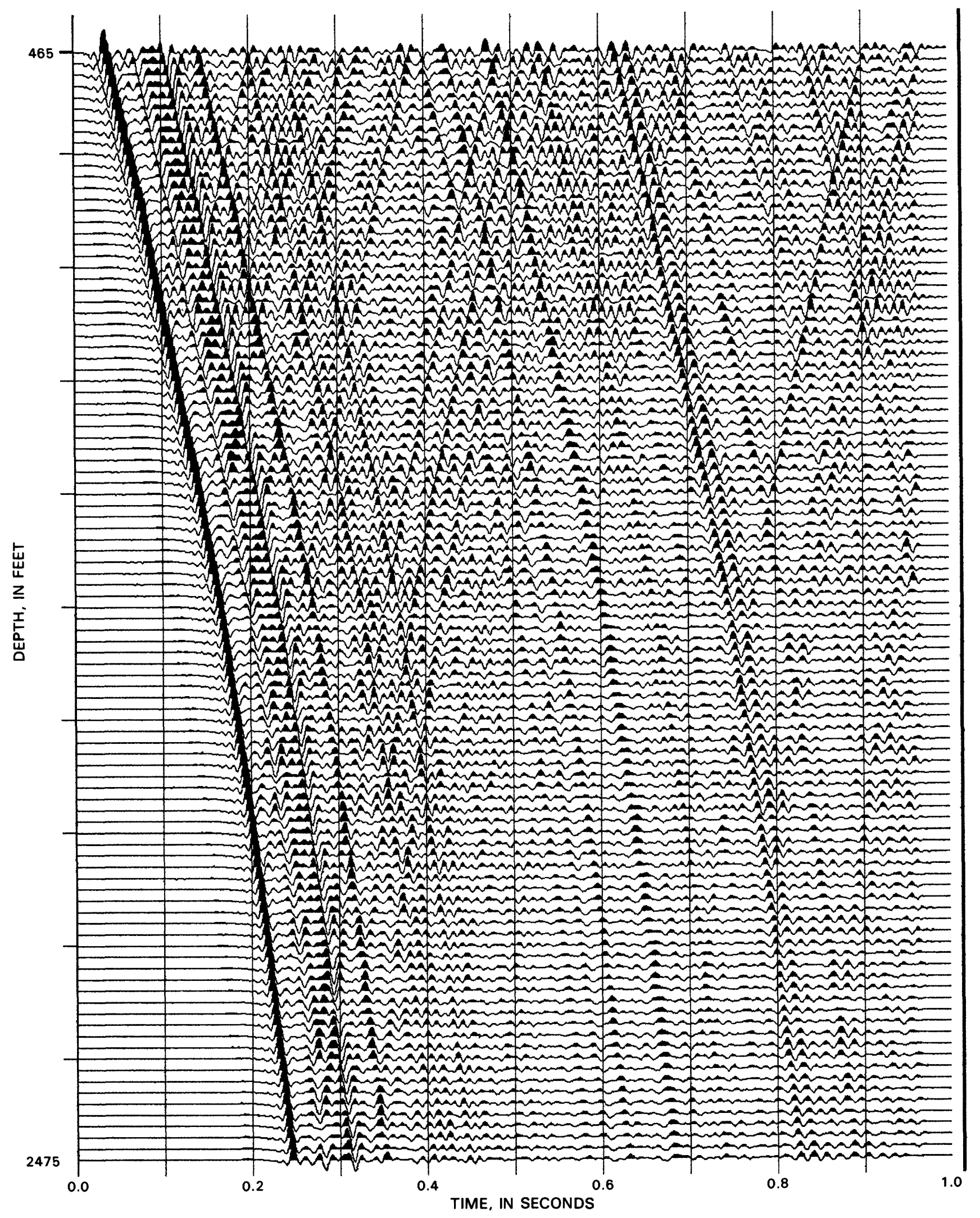

FIGURE IV-7.-Synthetic vertical seismic profile for the Coronado Collins well No. W-1, Wyoming (total wave field). 


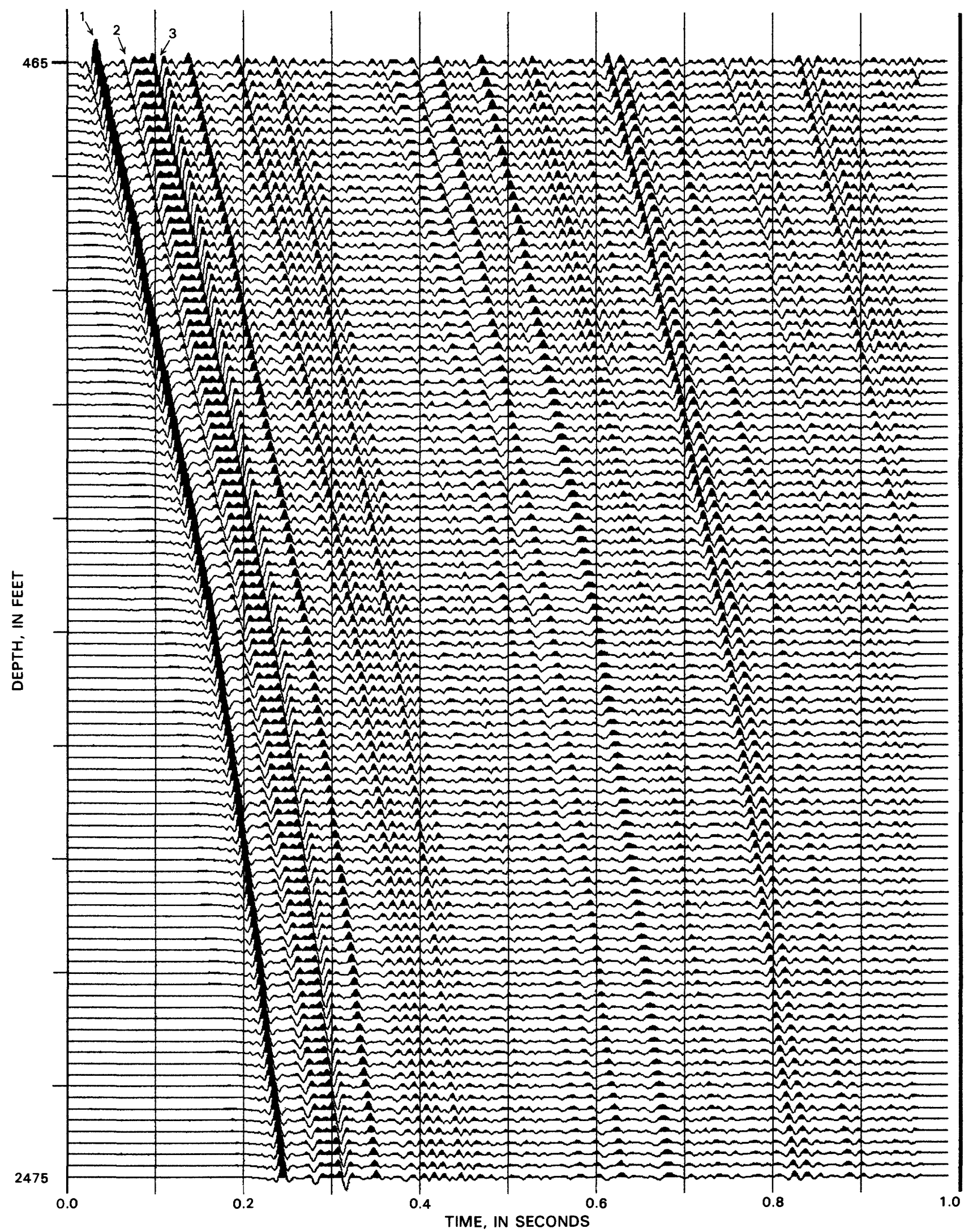

FIGURE IV-8.- Synthetic vertical seismic profile for the Coronado Collins well No. W-1, Wyoming (downgoing wave field). Arrow 1 , initial downgoing pulse; arrow 2, event reflected by base of weathered layer; arrow 3, event reflected at surface of the ground. 


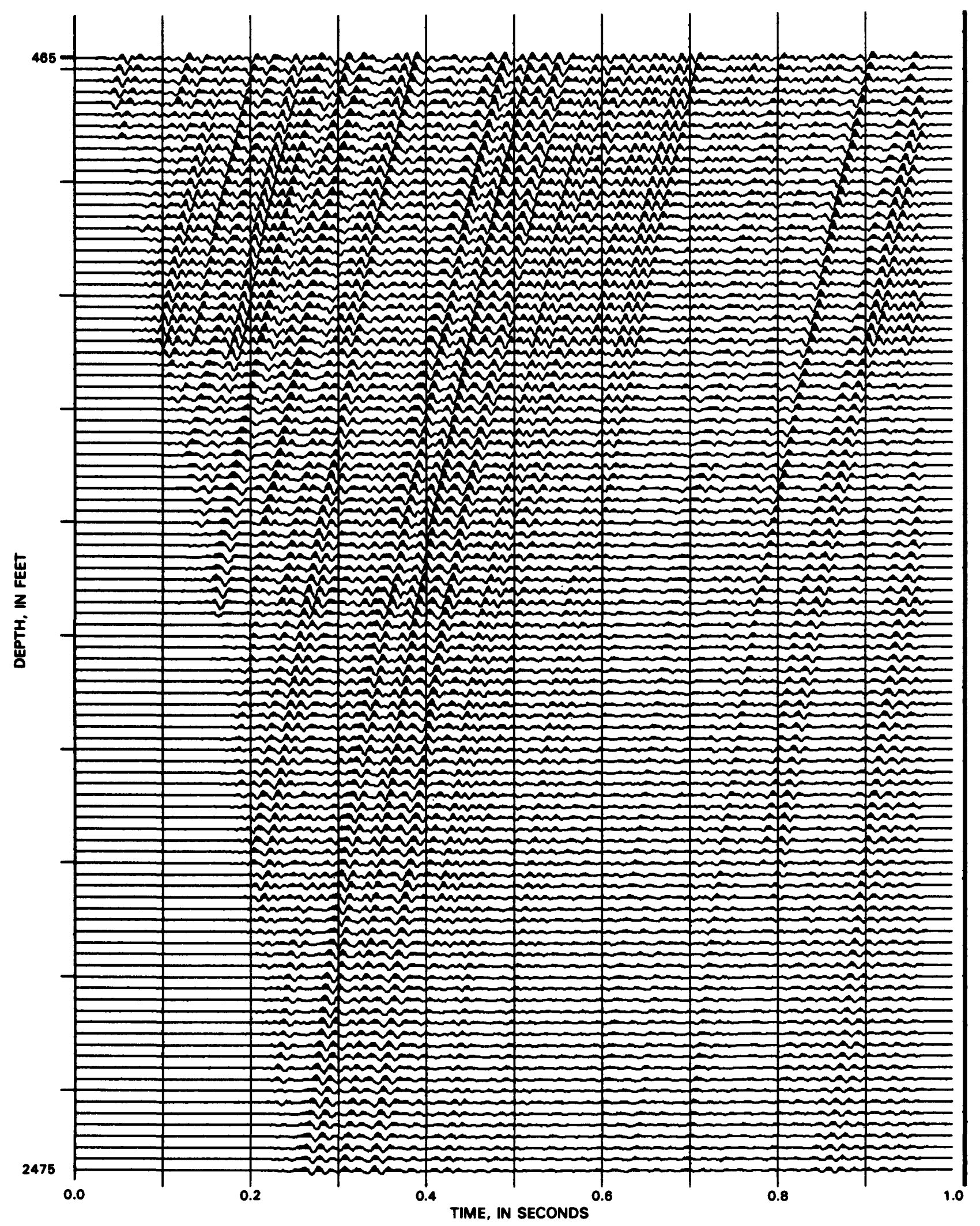

FIGURE IV-9.-Synthetic vertical seismic profile for the Coronado Collins well No. W-1, Wyoming (upward-traveling wave field). 
The parameters we used in this processing are:

Number of traces:

Signal estimation location:

Upper limit of signal moveout:

Lower limit of signal moveout:

Upper limit of noise moveout:

Lower limit of noise moveout:
12 center of group

$1 \mathrm{~ms}$

$1 \mathrm{~ms}$

$\infty$

$1 \mathrm{~ms}$
Ratio of signal to random noise: $\quad 1.0$

Ratio of signal to coherent noise, $R n$ :
$R n=1.0$
$R n=4 f-399$
$R n=0.5 f+55$
$0 \mathrm{~Hz}<f<100 \mathrm{H} q$ $100 \mathrm{~Hz}<f<130 \mathrm{~Hz}$ $130 \mathrm{~Hz}<f<500 \mathrm{~Hz}$

The computed filter using these parameters is shown in figure IV-10.

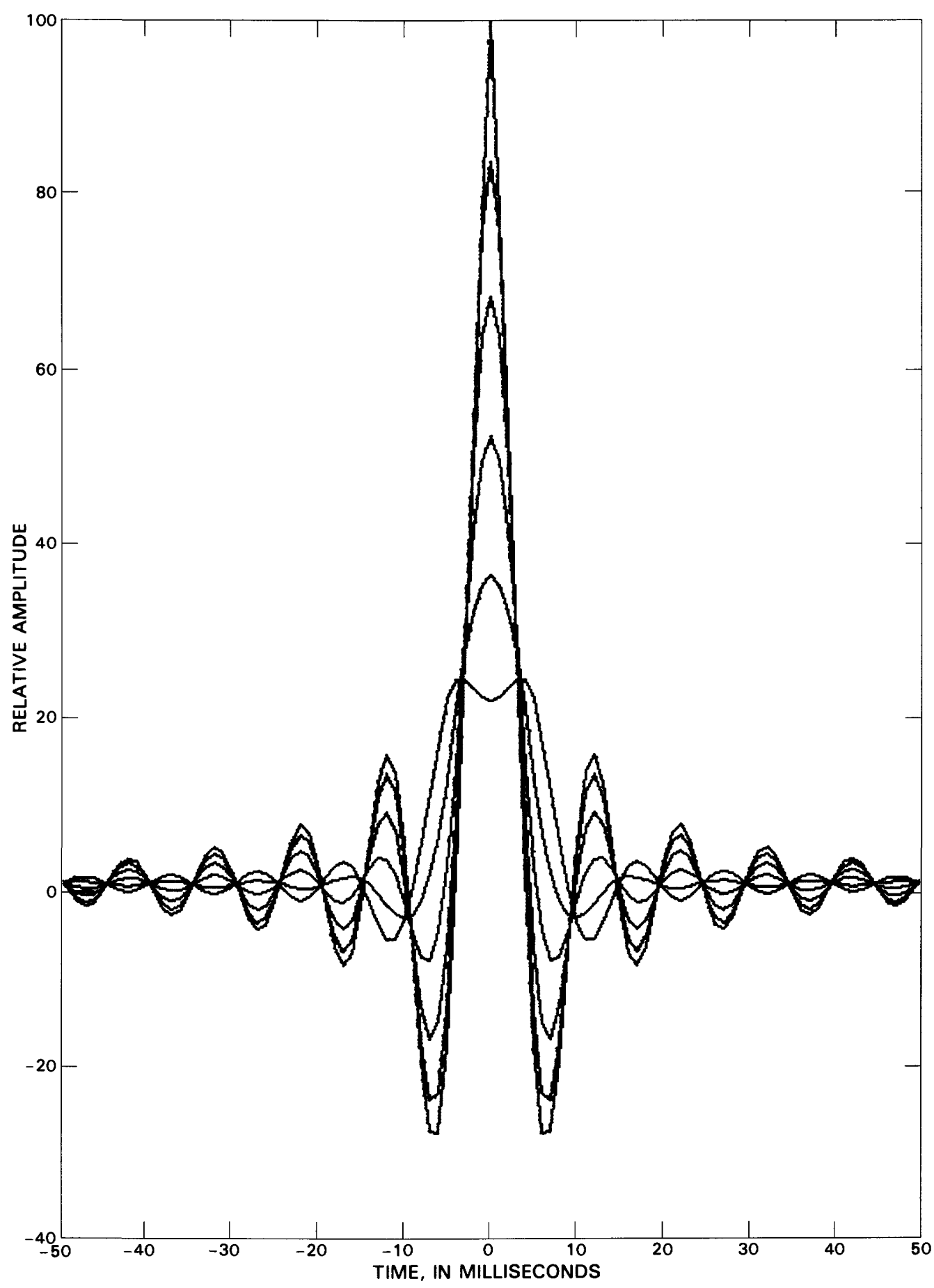

FIgURE IV-10.-Multichannel velocity filters. 


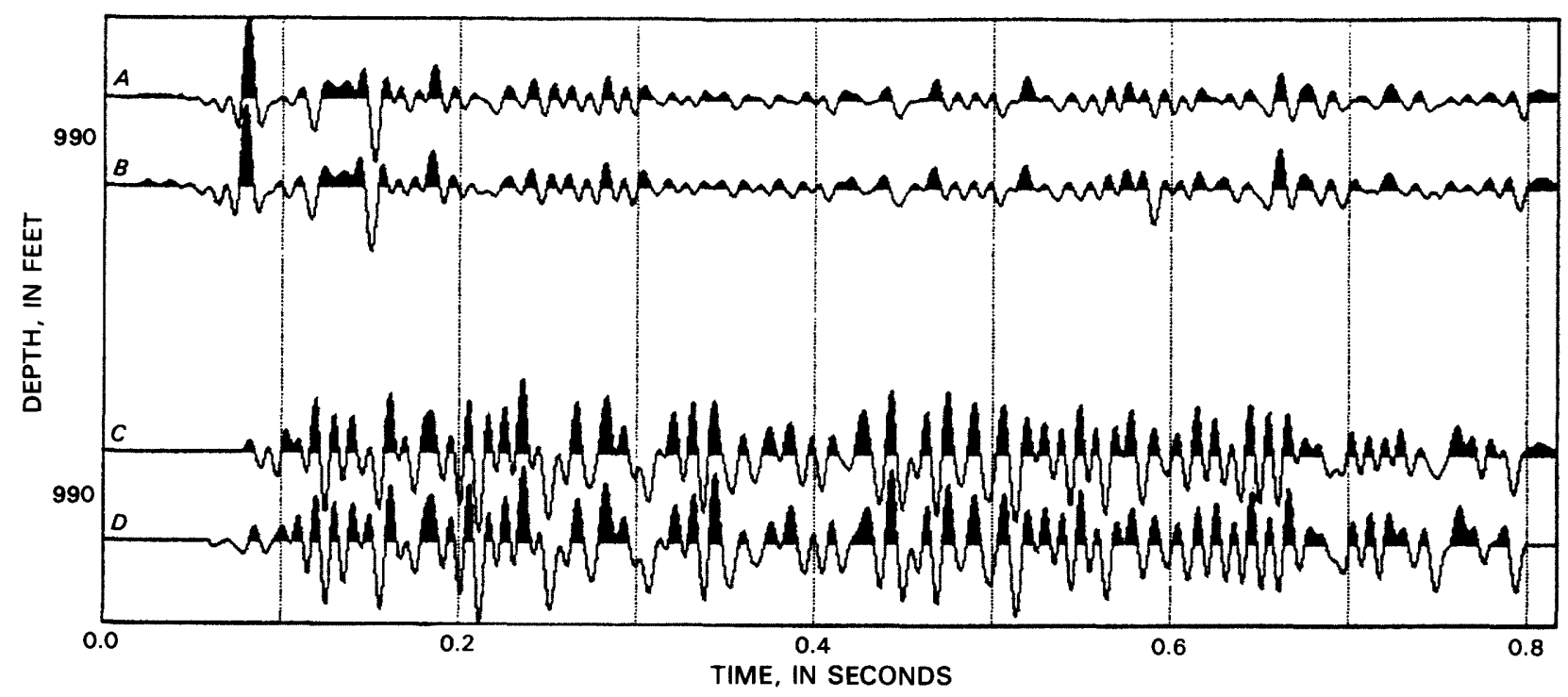

FIGURE IV-11.-Comparison between synthetic trace and 12-channel multichannel velocity-filtered trace at $990 \mathrm{ft}$ for Coronado Collins well No. W-1, Wyoming. $A$, Calculated downgoing wave field; $B$, downgoing wave field extracted from calculated total wave field by velocity filtering; $C$, upgoing wave field; $D$, upgoing wave field extracted from calculated total wave field by velocity filtering.

Figure IV-11 shows the velocity-filtered output at $990 \mathrm{ft}$ and compares them with the original synthetic traces. Notice that the wave shape for the velocity-filtered upgoing and downgoing waves are remarkably similar to the corresponding synthetic traces.

Figures IV-12 and figure IV-13 show the velocity-filtered downgoing and upgoing waves for the upper 21 traces of figure IV-7. In these figures, we shifted the tracer to aline the same events vertically. With these time shifts in mind, compare with figure IV -8 and figure IV-9. The matching between these two is excellent.

Velocity filtering is the most important step in processing the data. By separating upgoing and downgoing waves from the total wave field, we can identify a reflected event, locate its point of origin, and see how the reflected event changes as it comes to the surface. We also can see how the downgoing waves evolve with time and depth.

\section{VERTICAL STACKING}

After multichannel velocity filtering, we often use vertical stacking to further improve the signal-to-noise ratio. To stack the data vertically, we time-shift the data from two or more adjacent levels to aline coherent events with the same velocity. These recordings are then added to enhance coherent events with the same velocity. Vertical stacking amounts to additional velocity filtering. We have used two types of stacking in processing the data obtained in this investigation- "local" vertical stacking and "time-weighted" vertical stacking, or "cumulative summation."

By local stacking, we mean that the data from two to ten adjacent levels are combined, or stacked, to produce a single output. This output is assumed to represent the coherent seismic wave field, traveling at a specific velocity determined by the time shift before stacking. The number of recordings to be summed depends on the signal-to-noise ratio, degree of coherence, and spatial resolution desired.

Time-weighted stacking or cumulative summation is described most easily in terms of an example. Suppose we have recordings on 100 levels, level one at the top and level 100 at the bottom. Imagine that all the recordings have been time-shifted to bring the upwardtraveling events on all traces into vertical alinement.

Recording number 100 remains the same and is plotted as trace 100 . Numbers 99 and 100 are summed and plotted as 99 . Numbers 98,99 , and 100 are summed and plotted as trace 98 . In general, numbers $N,(N+1)$, $(N+2) \ldots 99,100$ are summed and plotted as trace number $N$. Finally, the last trace, number one, is the sum of all traces-1 through 100 . The resultant traces may be reshifted after stacking, if desired, to restore the correct (fiducial) times.

The effect of this procedure is that extremely small amplitude reflections, deep in the ground, are enormously enhanced by repeated summation. Small deep reflections get a huge boost in amplitude when this technique is used. Cumulative summation fails to show 


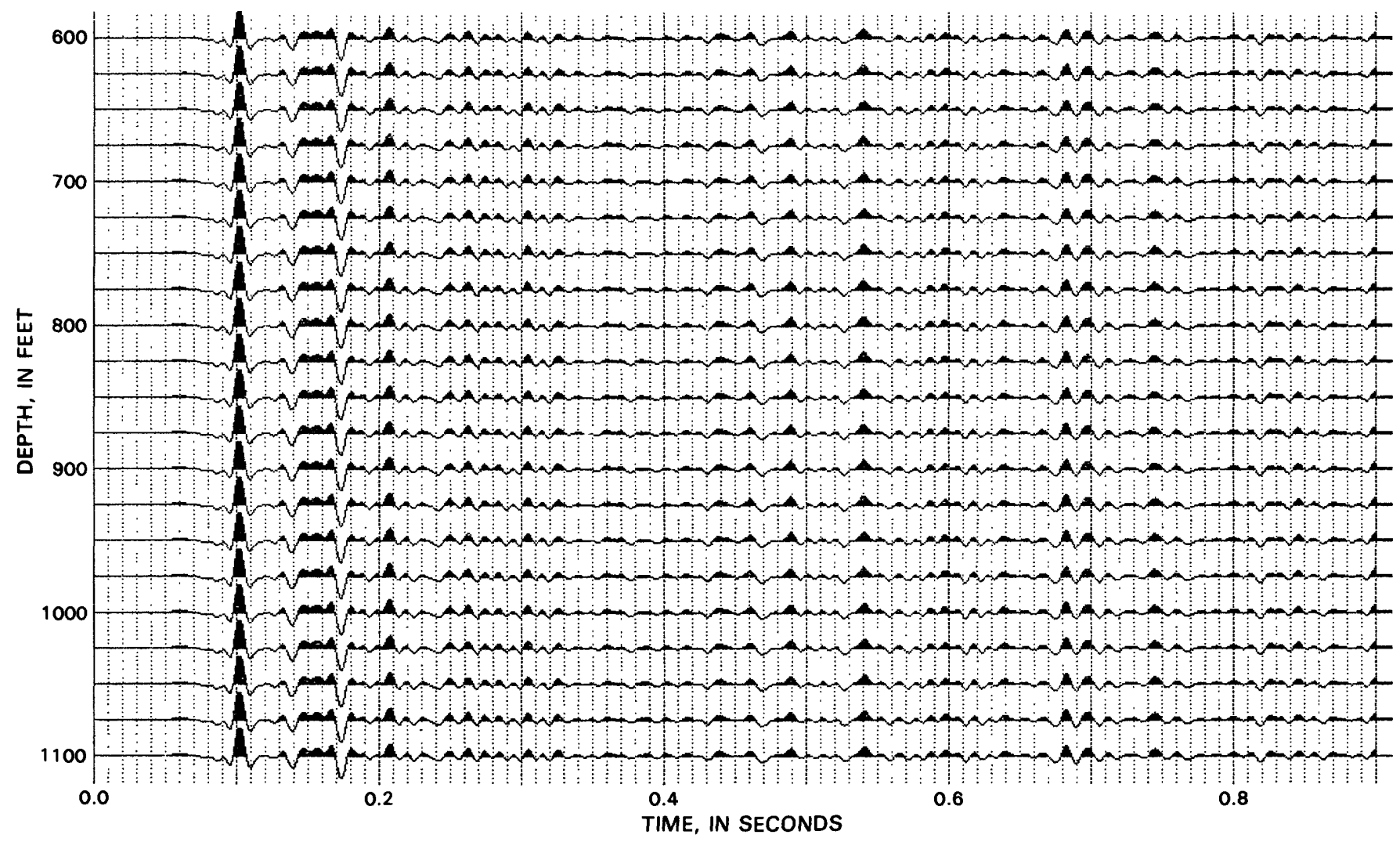

FIGURE IV-12.-Multichannel velocity filtered output of synthetic vertical seismic profile for Coronado Collins well No. W-1. Downgoing waves, time-shifted to aline downgoing waves.

changes in reflection waveforms as they move upward, and depth resolution suffers because of the large distance over which the summation is performed. These results often are effective in "tying" surface reflection data to the VSP. For this purpose, the loss in resolution is a good trade-off for improved signal-to-noise ratio.

\section{DOWNGOING WAVE-TRAIN DECONVOLUTION}

The downgoing wave from the source is neither an impulse nor a simple wavelet, but a complicated wave train. Reverberation of seismic energy trapped in the near-surface layers is largely responsible for this. This effect is shown in figure IV-8. In figure IV-8, arrow 1 represents the initial downgoing pulse; arrow 2 represents an event reflected by the base of the weathered layer; and arrow 3 represents an event reflected at the surface of the ground. Every subsurface layer will reflect this entire wave train. The recorded reflections thus contain a scrambled mixture of wave trains, not a series of discrete pulses from each layer. Geologic interpretation can be difficult under these circumstances. We need to compute the data set that would have been recorded if the original downwardtraveling wave train had been a single short pulse. This procedure is the essence of deconvolution. If the short pulse is to be a single positive excursion, or "spike," the process is called spiking deconvolution. The key step in spiking deconvolution is a good estimate of the autocorrelation of the recordings at each level. We can optimize the spiking operator to a certain extent by proper choice of operator length and delay.

The downward-traveling wave train becomes still longer and more complicated as it progresses into the earth, because each successive layer contributes its own reverberation to the wave train as it goes by. By using the deconvolution just described, we can compute a set of data that is an estimate of the recordings we would have had if the downward-traveling wave train had been a spike, or short impulse, at every depth. This procedure is called downgoing wave-train deconvolution. 


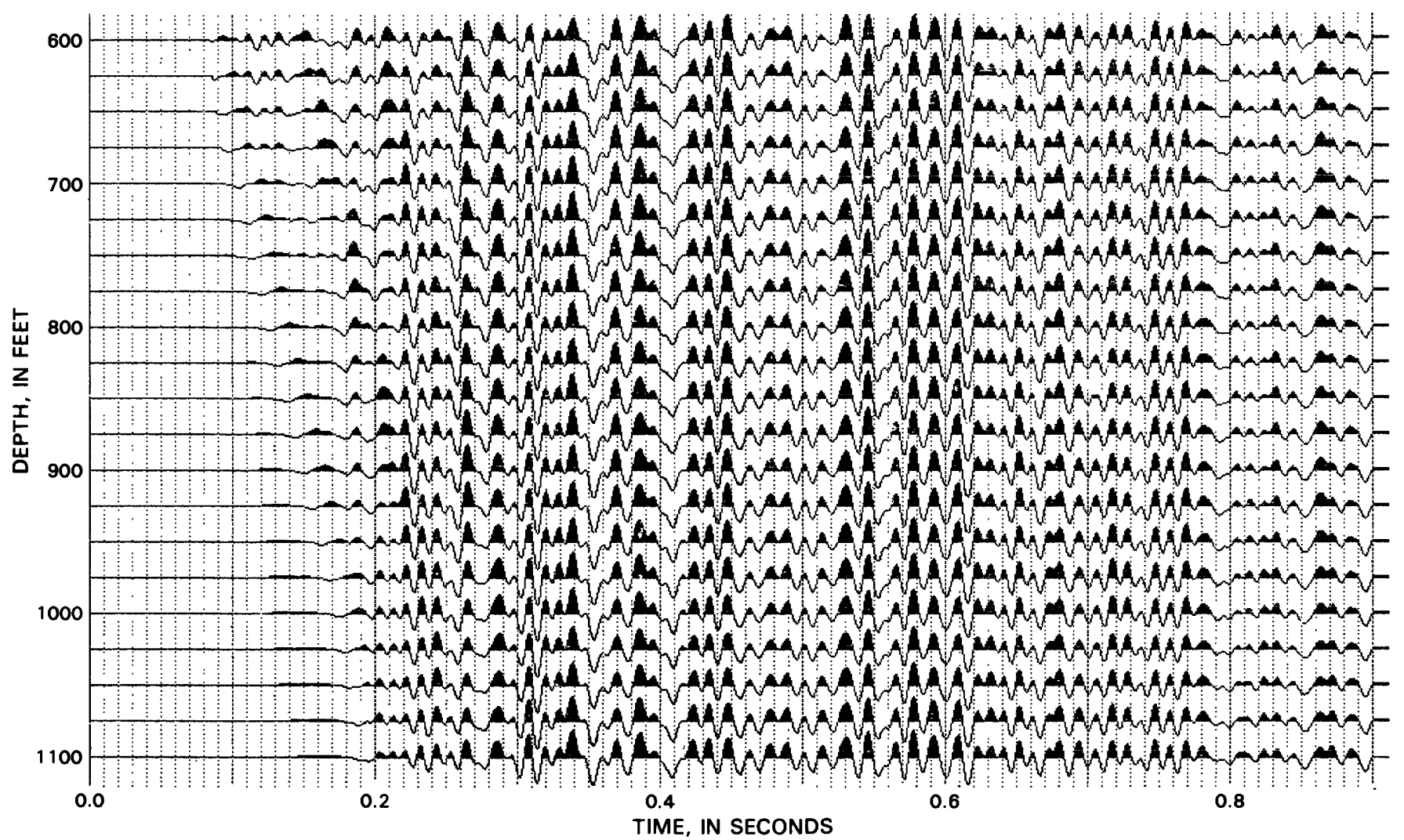

FIGURE IV-13.-Multichannel velocity filtered output of synthetic vertical seismic profile for Coronado Collins No. W-1 well. Upgoing waves, time-shifted to aline upgoing waves.

To study the evolution of a short downgoing wavelet, we can calculate a downgoing wave-spiking filter, a deconvolution operator for a shallow recording, and apply this operator to all deeper recordings.

Figure IV-14 shows the result of applying a downgoing wave-spiking filter. It is derived from the top trace of figure IV-12. It was applied to the data in figure IV-12 to create the data shown in figure IV-14. Figure IV-15 shows the result of applying the same filter to the data shown in figure IV-13. By comparing figure IV-12 with figure IV-14, and figure IV-13 with figure IV-15, we see a considerable improvement in interpretability.

\section{TRANSFER FUNCTION}

A seismogram can be calculated by the convolution of the input wavelet with some function that is related to the reflectivity of the medium, superimposed with measurement noise. In mathematical terms, this calculation can be described as follows:

$$
S(t)=W(t) * f R(t)+N(t)
$$

where

$$
\begin{aligned}
S(t) & =\text { seismogram, } \\
W(t) & =\text { input wavelet, } \\
N(t) & =\text { measurement noises for which we assume } \\
& \quad \text { an uncorrelated random distribution, } \\
R(t) & =\text { reflectivity, and } \\
* & =\text { convolution. }
\end{aligned}
$$

We define the transfer function of a rock sequence $T(t)$ as follows:

$$
O(t)=T(t)^{*} I(t)+N(t),
$$

where

$$
\begin{aligned}
& O(t)=\text { output, } \\
& I(t)=\text { input, and } \\
& T(t)=\text { transfer function. }
\end{aligned}
$$

A transfer function is the same as the impulse response of a linear system when there is no noise.

The transfer function concept has a great deal of appeal in seismic data interpretation because we can use 


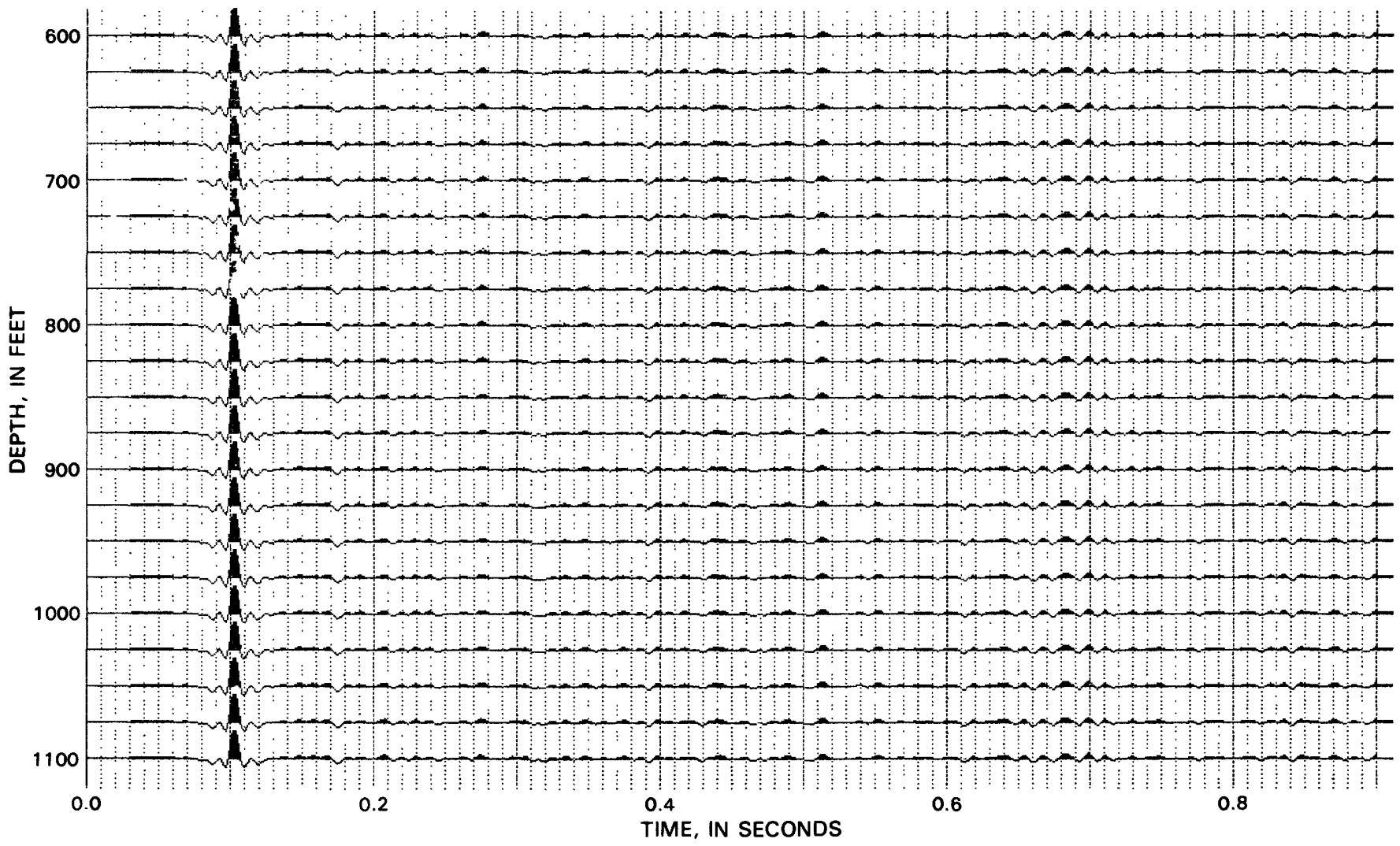

FIGURE IV-14.-Result of applying a downgoing wave-train deconvolution operator to the data shown in figure IV-12.

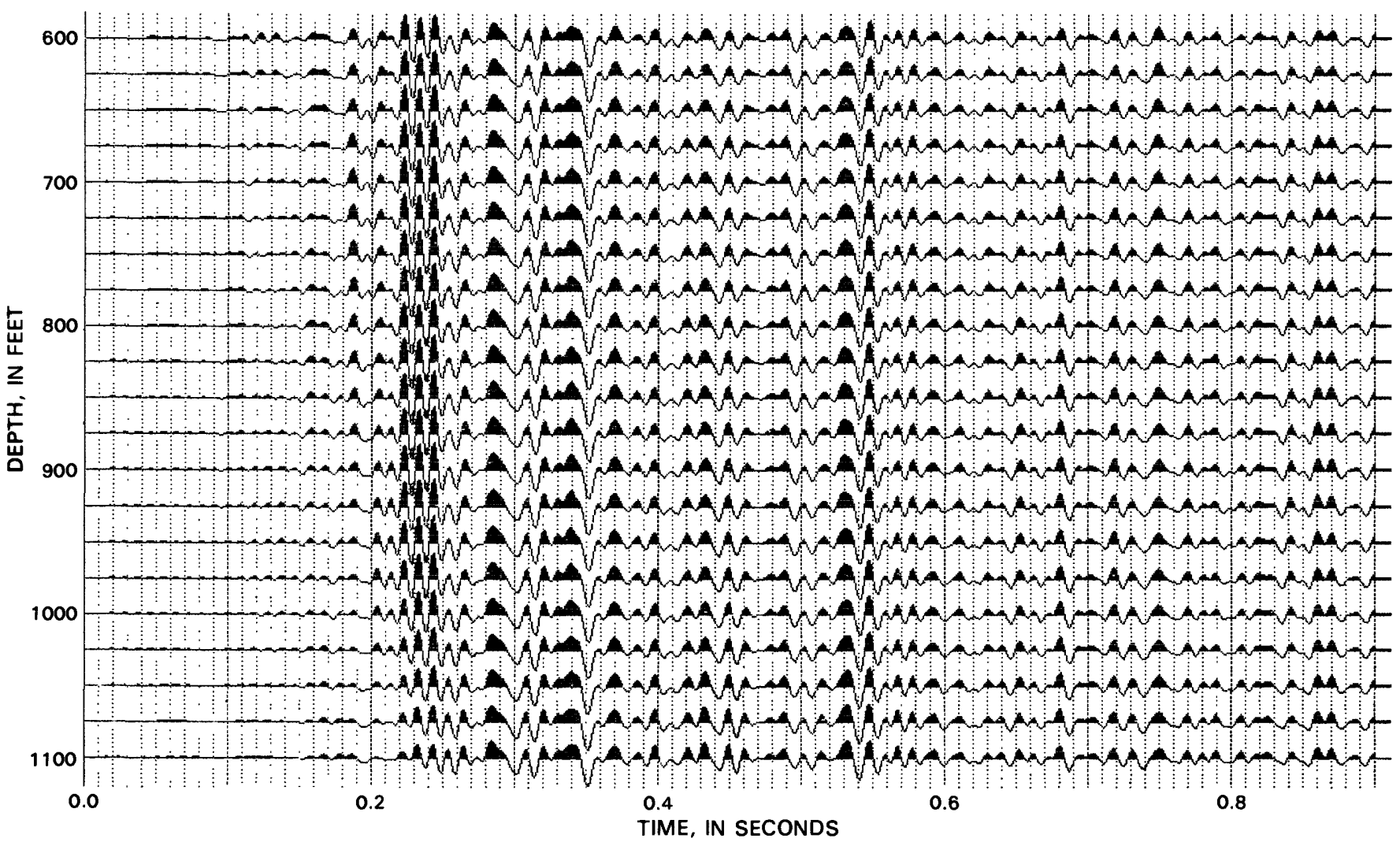

FIGURE IV-15.-Result of applying a downgoing wave-train deconvolution operator to the data shown in figure IV-13. 
it to avoid making an intricate detailed analysis of the interaction between the wave field and the rocks within some given section of earth. We can concentrate our attention instead on the way that section of earth, taken as a gross unit, changes the seismic "input" into the seismic "output." In this sense, the transfer function completely describes all the acoustic properties of the rock unit. This principle is discussed by Tullos and Reed (1969).

In plane-layered media and normally incident, plane compressional waves, there are two outputs and two transfer functions. If the input is regarded as a wave train entering the top of the layer, one output is the resultant upward-reflected wave train. The other is the resultant wave train emerging from the bottom of the layer.

We shall discuss these two transfer functions separately; first, the one related to the transmitted wave train, and then the one related to the reflected wave train.

Because there is a duality between convolution carried out on a time series and multiplication carried out on the Fourier transform of the time series, the Fourier transform of the transfer function contains the same information about a rock unit as the corresponding transfer function itself. In some instances, the Fourier amplitude spectrum of the transfer function of the rock may show its diagnostic properties better than the time-domain representation. In the transform function analysis to follow, we have made considerable use of the Fourier transform or frequency-domain method.

\section{DOWNGOING WAVES}

Let the input $D_{1}(t)$ be a downgoing wave at level 1 and the output $D_{2}(t)$ be a downgoing wave at level 2 , which is deeper than level 1. Taking the Fourier transformer of $D_{1}(t)$ and $D_{2}(t)$, we can estimate a transfer function in the frequency domain, that is:

$$
\widetilde{T}(w)=\frac{\widetilde{D}_{2}(w)}{\widetilde{C}_{1}(w)},
$$

where $\widetilde{T}(w), \widetilde{D}_{1}(w)$, and $\widetilde{D}_{2}(w)$ are the Fourier transforms of $T(t), D_{1}(t)$, and $D_{2}(t)$, respectively.

This spectral ratio will reveal the apparent attenuation, which is the result both of inelastic attenuation within the medium, internal reflections, and other mechanisms.

Figure IV-16A shows the normalized amplitude spectra of the downgoing waves for the Pfister Fee No.
1 well VSP data after downgoing wave-train deconvolution. The heavy line represents the spectrum at 825 $\mathrm{ft}$, and the light line shows the spectrum at $2,625 \mathrm{ft}$. We calculated the Fourier transform of the initial 200 ms of the downgoing wave.

Figure IV-16B shows the spectral ratio of the wave trains at these same depths. In this figure, the heavy line represents the ratio using the initial $200 \mathrm{~ms}$ from the onset time of the downgoing wave train, and the light line indicates the spectral ratio when only the first $60 \mathrm{~ms}$ (from the onset time) of the data is used.

Notice the similarity of the two ratios. This suggests that if the time gate of the downgoing wave used in calculating the Fourier transform is not long, compared with the initial downgoing pulse duration, we can still measure a reasonably accurate apparent attenuation.

\section{UPGOING AND DOWNGOING WAVES}

We treat the downgoing wave as an input and the resultant upgoing, or reflected, wave as an output of the linear system. We shall describe two methods: a shaping filter approach and the Kalman filter approach.

1. Shaping filter approach. - Let $D(t)$ be the downgoing wave at the $i$-th well-phone location and $U(t)$ be the upgoing wave at the same location. We derive a Wiener-shaping filter, $T(t)$, such that:

$$
D(t)^{*} T(t)=U(t)
$$

or in the frequency domain,

$$
\widetilde{T}(w)=\frac{\widetilde{U}(w)}{\widetilde{D}(w)} .
$$

If

$$
D(t)=\delta(t)
$$

then

$$
\widetilde{T}(w)=\widetilde{U}(w)
$$

This transfer function, $T(t)$, is the reflection seismogram that would be generated by a source at the $i$-th location under the assumption that the medium above the $i$-th location is a homogeneous half-space. In other words, $T(t)$ is the transfer function of the lower medium below the $i$-th level.

2. Kalman filter approach.-The general principles of the Kalman filtering are described in Medith (1969). The Kalman filter applications to geophysical process- 


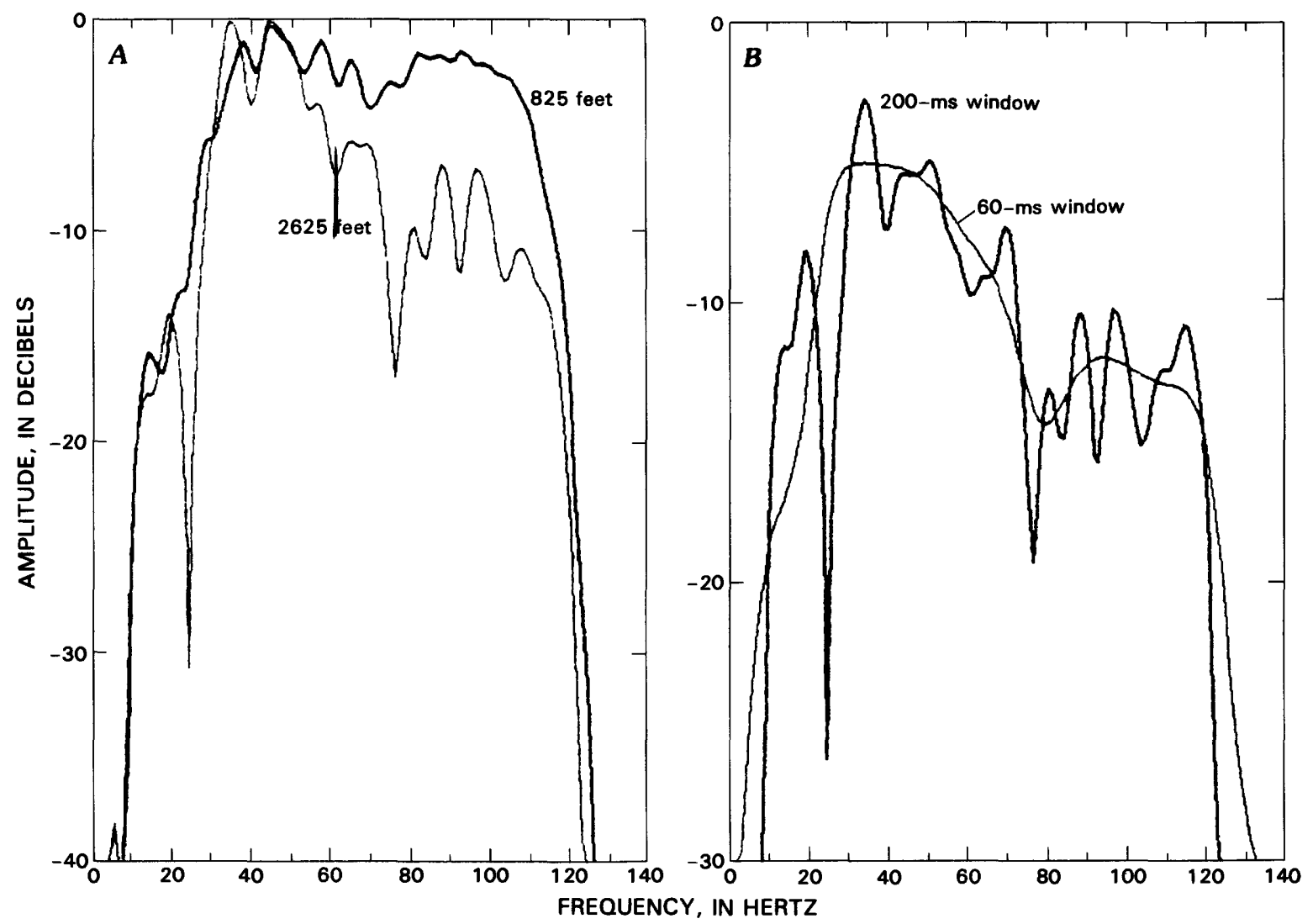

FIGURE IV-16.-Pfister Fee No. 1 well, Wyoming. A, Normalized amplitude spectra of downgoing waves using the initial $200 \mathrm{~ms}$ (millisecond) of the vertical seismic profile at $825 \mathrm{ft}$ and $2,625 \mathrm{ft} ; B$, transfer functions in the frequency domain using $60 \mathrm{~ms}$ and $200 \mathrm{~ms}$ of the initial downgoing waves at 825 and $2,625 \mathrm{ft}$.

ing are numerous. In the following application of Kalman filtering to estimate a transfer function, we followed Mendel and Kormylo (1978).

The main idea in using Kalman filtering to estimate the transfer function is to estimate an uncorrelated white-noise sequence from the seismogram. This uncorrelated white-noise sequence requirement is satisfied reasonably well by the reflection seismogram. In this report, we treat the transfer function as an uncorrelated white-noise sequence.

To implement the Kalman estimation, we used the following steps: (1) Derive a shaping filter with a desired output $e^{-\alpha t} \sin \left(w_{E} t\right)$ using a downgoing wave, (2) apply this shaping filter to the corresponding upgoing waves, and (3) apply the Kalman estimation process described by Mendel and Kormylo (1978).

Figure IV-17 shows the input used for Kalman filtering. In this figure, trace $A$ shows the reflection coefficient series computed from the sonic log of the Coronado Collins No. W-1 well, starting at $990 \mathrm{ft}$, with sampling at intervals of $1 \mathrm{~ms}$. Trace $B$ shows the input waveform that is taken as exp $(-0.1) t \sin 10 t$. Trace $C$ shows the result of convolution of the input wavelet with the reflection coefficients. Trace $D$ shows the result of zero-phase band-pass filtering $(10 / 20-100 / 125 \mathrm{~Hz})$ of trace $A$. Using this noise-free seismogram (trace $C$ ), we applied Kalman filtering to estimate the reflection coefficients.

Figure IV-18 shows the result of this approach. In figure IV-18, trace $A$ represents the estimation of reflection coefficients, and trace $B$ shows the result of zero-phase band-pass filtering $(10 / 20-100 / 125 \mathrm{~Hz})$ of the trace $A$. This figure shows that we can estimate the reflection coefficients in this noise-free sequence exactly.

Figure IV-19 shows the result of the application of Kalman filtering to the top trace on figure IV-15. Trace $A$ is the estimated transfer function assuming the signal-to-random noise ratio is 100 , and trace $B$ is the estimated transfer function assuming the signal-to-random noise ratio is 20 . Trace $C$ and trace $D$ are the zero-phase band-pass filtering results (10/20-100/125 $\mathrm{Hz}$ ) of trace $A$ and trace $B$, respectively. 


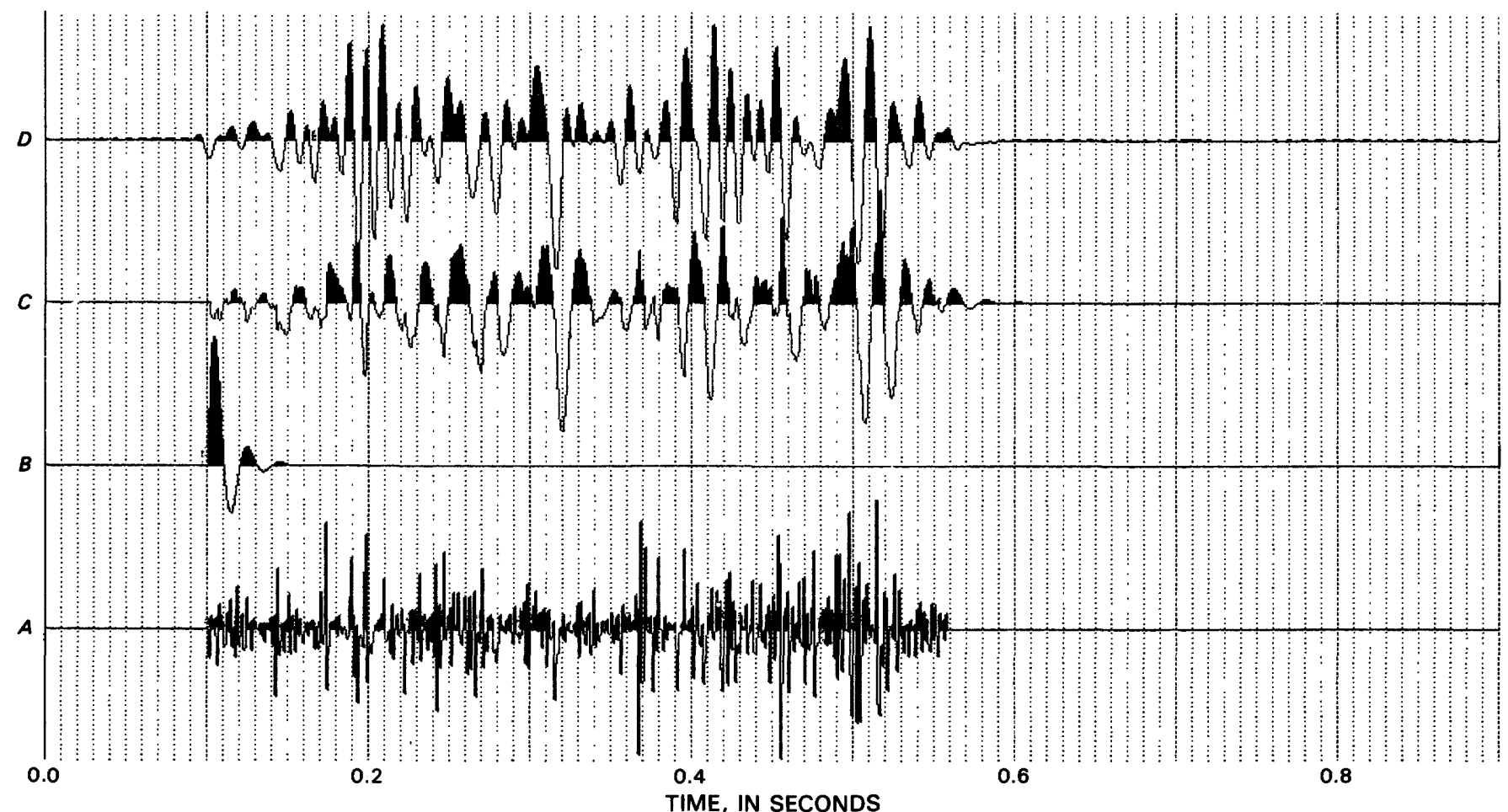

FIGURE IV-17.-Noise-free synthetic seismogram used to test the Kalman filter approach to estimating a transfer function from a vertical seismic profile. $A$, Reflectivity series; $B$, input wavelet; $C$, convolution product of $A$ and $B ; D$, zero-phase band-pass filtered (10/20-100/125 Hz) version of $A$.

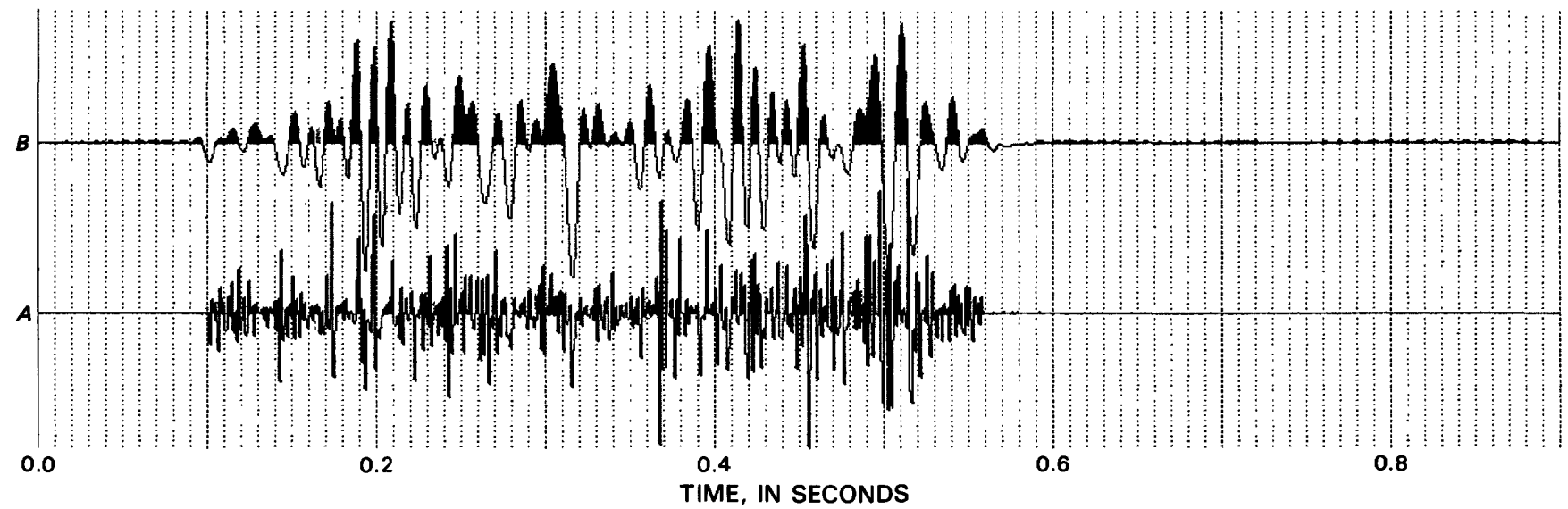

FIGURE IV-18.-Result of using the synthetic seismogram shown in figure IV-17 to test the Kalman filter. $A$, Estimated reflectivity series; $B$, zero-phase band-pass filtered (10/20-100/125 Hz) version of $A$. 


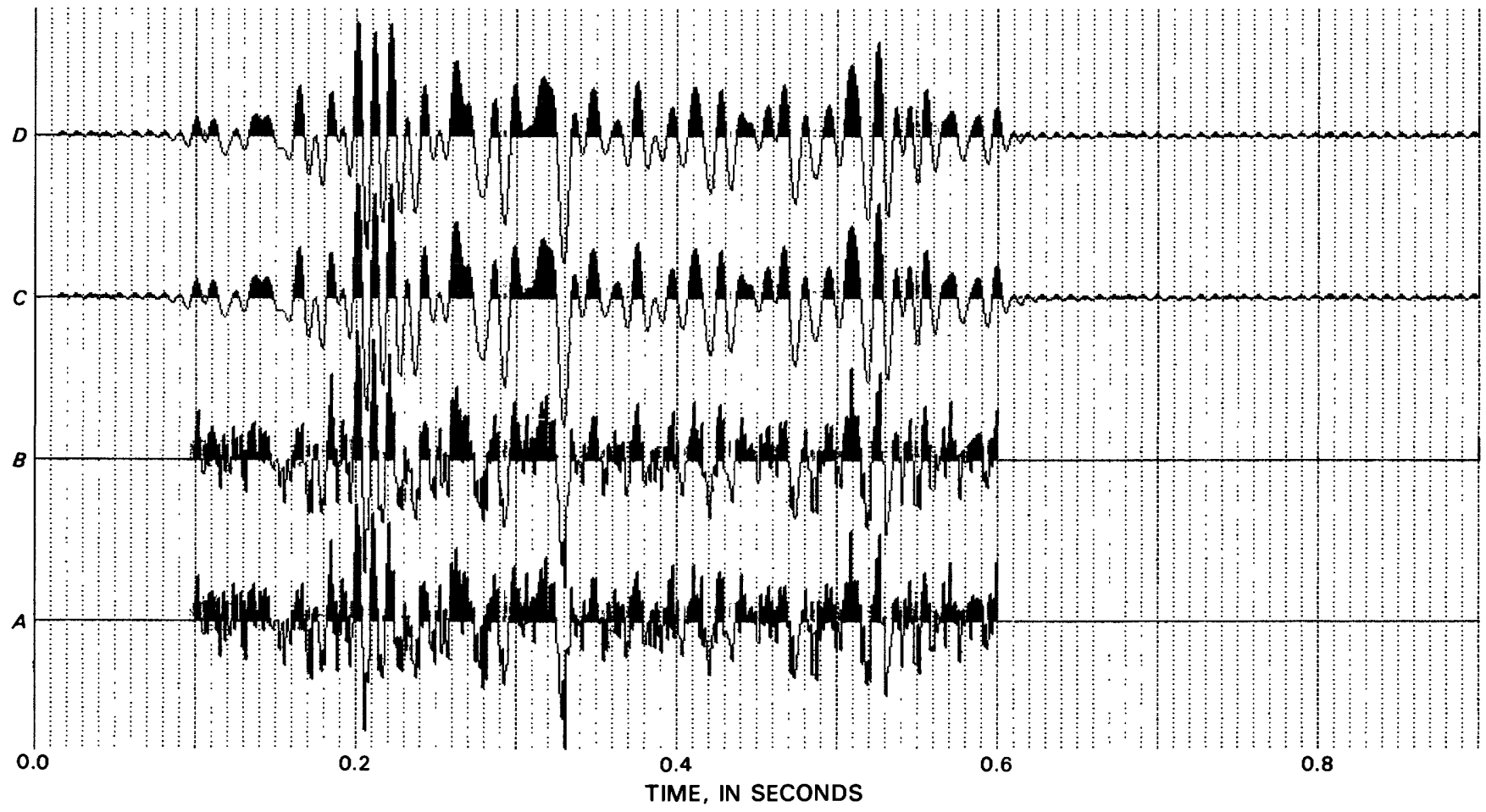

Figure IV-19.-Estimated transfer function of the top trace of figure IV-15 by Kalman filtering. $A$, Signal-to-noise ratio is assumed to be $100 ; B$, signal-to-noise ratio is assumed to be $20 ; C, D$, zero-phase band-pass filtered $(10 / 20-100 / 125 \mathrm{~Hz})$ version of $A$ and $B$, respectively.

This transfer function should be similar to the reflection coefficients shown on figure IV-17. The obvious discrepancy between these two is the amplitude loss around $400 \mathrm{~ms}$. We recall that in preparing the input for this Kalman filtering operation, we applied multichannel velocity filtering, downgoing wave-train deconvolution, and a shaping filter. Because none of these processes is perfect, we accumulated errors during the processing. The input trace to Kalman filtering also could have a few multiples in it.

Some of the advantages of using Kalman filtering to estimate the transfer functions are, in our opinion, (1) it is a time-varying filtering scheme that is easy to implement, (2) there is control over the signal-to-noise ratio in estimating transfer functions, and (3) transfer functions at time $K \Delta t$ can be estimated using measurements up to $K \Delta t+L \Delta t$, where $K$ and $L$ are any integer number and $t$ is the sampling interval. When $L>1$, we can estimate a better transfer function when the data are noisy.

\section{IMPEDANGE LOG ESTIMATION}

In some instances, the ultimate goal of seismic data processing is to estimate the impedance of the earth as a function of depth; that is, to generate an acoustic impedance $\log$ from the reflected seismic arrivals. The impedance log calculation certainly is important in the Madison investigation, because impedance seems directly related to water productivity.

In an ideal situation, the calculation of the impedance $\log$ is rather straightforward. Due to a host of factors, the actual recordings of the reflected waveforms are far from ideal. The calculation is a sensitive one and, therefore, small measurement errors can cause large errors in the impedance calculations.

Impedance calculations from vertical seismic profiles are easier to make and are more accurate than those from surface reflection data because the seismic source is known more accurately and the reflected wave field can be measured near the reflecting sequence of interest. We have estimated impedance logs from the Madison VSP data as a feasibility study. If the attempt is successful (as it turned out to be), then impedance measurement from surface data is reasonable to attempt. If the attempt fails, it strongly suggests that a similar attempt using surface recorded data will fail also.

Our impedance estimation proceeds as follows:

1. Generate the reflection transfer function.

2. Assume that each prominent "event" (peak or trough) in the transfer function corresponds to a change in impedance. 

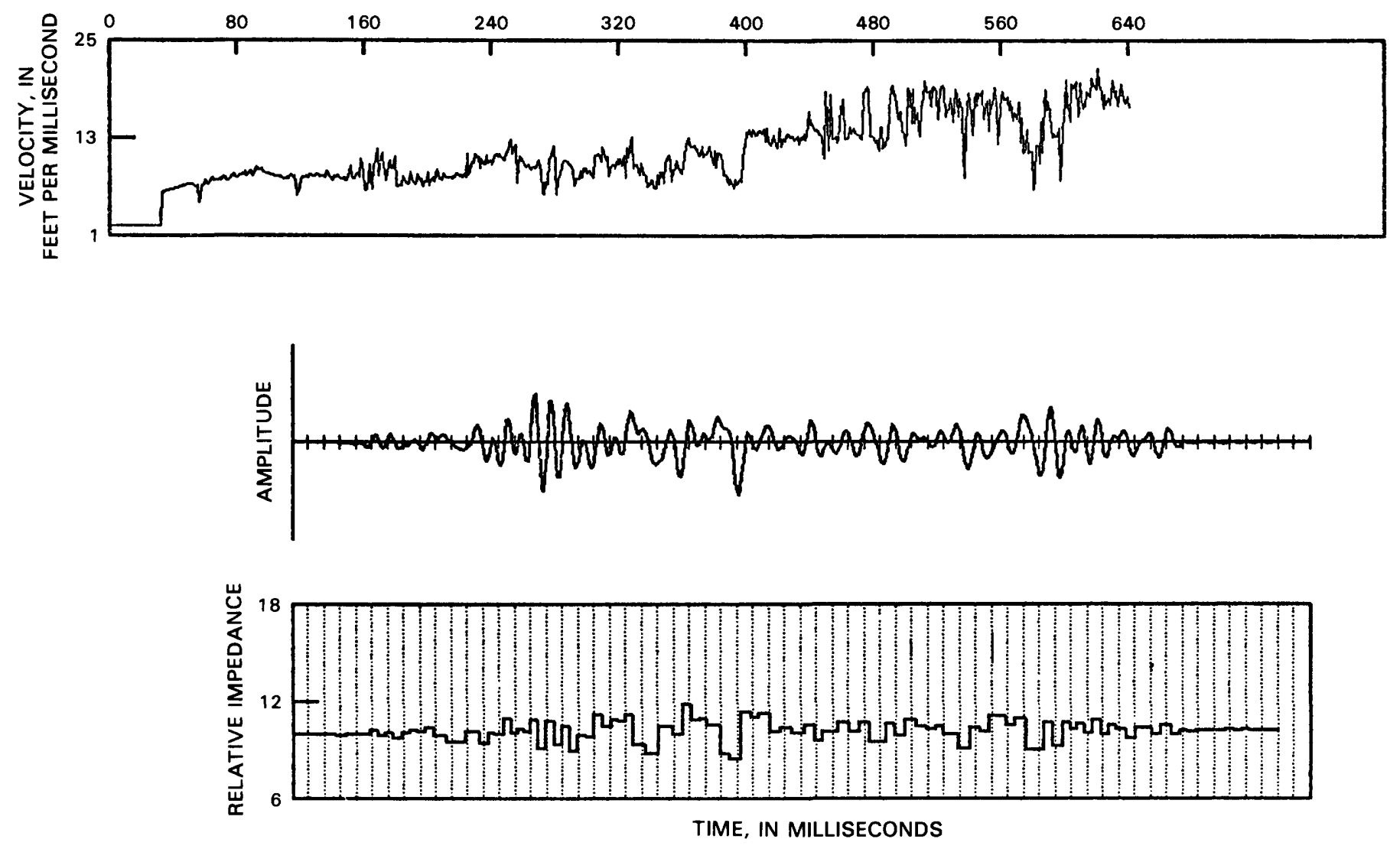

FIGURE IV-20.-Result of estimation of an acoustic impedance log from the reflected wave train of a synthetic vertical seismic profile, Coronado Collins No. W-1 well, Wyoming. Top, actual acoustic log in two-way travel time; middle, estimated transfer function (fig. IV-19C); bottom, estimated relative impedance log.

3. Assume a reasonable initial impedance. Calculate the change in impedance from the amplitude of each prominent event.

4. Add each change to the previous impedance value to generate a new value.

Several results of the application of this idea to actual Madison data are given elsewhere in this report. In figure IV-20, we see one example of applying this technique to the Coronado Collins No. W-1 well synthetic VSP. The bottom trace shows the impedance function estimated from the transfer function shown as the middle trace. The top trace shows the actual impedance. Both high-frequency detail and low-frequency trend have been lost. But the prominent local impedance variations clearly are evident.

\section{SUMMARY}

Vertical seismic profiles contain a wealth of exploration information about the subsurface. Some of this information can be used directly to evaluate formations penetrated by the drill. Additional information can be used in conjunction with surface profiles and greatly increases the value and interpretability of the surface profiles. We have shown that a considerable amount of computer processing of digitally recorded VSP data is required in order to obtain the full benefit of these data.

In this chapter, we presented a sequence of steps to computer-process VSP data. The details of the processing steps vary according to the specific data set, and additional steps could be required to meet particular processing objectives. In most instances, the following key steps were used to understand VSP data and to extract valuable information for seismic exploration:

1. Wavelet shaping, using monitor records for the detailed study of dynamics and kinematics of wavefields.

2. Separation of the upgoing and downgoing waves from the recorded total wavefields in order to understand the VSP and to utilize the data.

3. Computation of transfer functions using input and output pairs at each recorded depth to better estimate the acoustic properties of rocks.

4. Calculation of acoustic impedance logs from reflected wave-train recordings made deep in the earth. 



\author{
A SEISMIC-STRATIGRAPHIC INVESTIGATION OF THE MADISON AND ASSOCIATED \\ AQUIFERS-APPLICATION TO GROUND-WATER EXPLORATION, POWDER RIVER BASIN, \\ MONTANA-WYOMING
}

\title{
ACQUISITION, PROCESSING, AND INTERPRETATION OF VERTIGAL SEISMIC PROFILES
}

\author{
CHAPTER V
}

By A. H. Balch, M. W. LeE and RoberT T. Ryder

\section{CONTENTS}

Introduction $\ldots \ldots \ldots \ldots \ldots \ldots \ldots$

The USGS Madison No. 1 well . . . . . . . . . . . . Stratigraphy, well history, and aquifer properties . . Vertical seismic profile data acquisition ....... Vertical seismic profile data processing ......... Identification of stratigraphic horizons on the vertical seis-

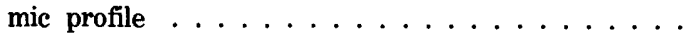

The USGS Madison No. 2 well . . . . . . . . . . . Stratigraphy, well history, and aquifer properties . . Vertical seismic profile data acquisition . . . . . . . Vertical seismic profile data processing ........ Identification of stratigraphic horizons on the vertical seis-

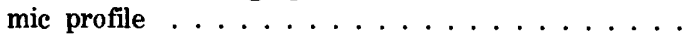

Sam Gary Bell Creek Madison No. 1 well ..... . . . Stratigraphy, well history, and aquifer properties .. Vertical seismic profile data aquisition . . . . . . Vertical seismic profile data processing ........

Identification of stratigraphic horizons on the vertical seismic profile

\begin{tabular}{|c|c|}
\hline & \\
\hline 57 & Coronado Collins No. W-1 well \\
\hline 57 & Stratigraphy, well history, and aquifer properties \\
\hline 57 & Vertical seismic profile data acquisition \\
\hline 57 & smic profile data proce \\
\hline 59 & $\begin{array}{l}\text { of stratigraphic horizons on the vertical seis- } \\
\text { e } \ldots \ldots \ldots \ldots \ldots \ldots \ldots \ldots\end{array}$ \\
\hline 60 & Bechtel E \\
\hline 61 & uifer properties .. \\
\hline 61 & Vertical seismic profile data acquisition $\ldots \ldots \ldots$ \\
\hline 62 & Vertical seismic profile data processing $\ldots \cdots \cdots$ \\
\hline 65 & $\ldots \ldots \ldots$ \\
\hline 66 & ter \\
\hline 66 & properties \\
\hline 66 & file data acquisition $\ldots \ldots \ldots$ \\
\hline 69 & $\begin{array}{l}\text { Vertical seismic profile data processing } \ldots \ldots \\
\text { Identification of stratigraphic horizons on the vertical seis- } \\
\text { mic profile } \ldots \ldots \ldots \ldots \ldots \ldots \ldots \ldots \ldots\end{array}$ \\
\hline
\end{tabular}

Page

\section{ILLUSTRATIONS}

FIgURE V-1. Lithologic and velocity logs of USGS Madison No. 1 well tied to the seismic wave field from vertical seismic profile

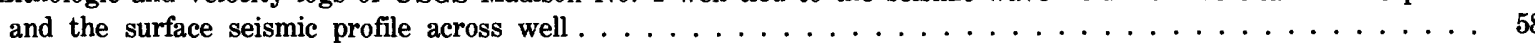

V-2. Raw vertical seismic profile data recorded at the USGS Madison No. 1 well using an explosive source .....6 60

V-3. Raw vertical seismic profile data recorded at the USGS Madison No. 1 well using LSS-3 surface air gun . . 61

$\mathrm{V}-4$. Processing flow sheet for the data shown in figure $\mathrm{V}-3 \ldots \ldots \ldots$

V-5. Calculation of the transfer functions of the Madison aquifer interval from vertical seismic profile data at the USGS Madison No. 1 well . . . . . . . . . . . . . . . . . . . . . . . . . . . 62

V-6. Lithologic and velocity logs of the USGS Madison No. 2 well tied to the total seismic wave field from vertical seismic profile and the surface seismic profile across well $\ldots \ldots \ldots \ldots \ldots$

V-7. Summed raw vertical seismic profile data from the USGS Madison No. 2 well . . . . . . . . . . . . . . 64

V-8. Data processing flow sheet for the vertical seismic profile from the USGS Madison No. 2 well . . . . . . . 65

V-9. Calculation of the transfer functions of the Madison aquifer interval from vertical seismic profile data at the USGS Madison No. 2 well . . . . . . . . . . . . . . . . . . . . . . . . 
FIGURE V-10. Lithologic and velocity logs of Sam Gary Bell Creek Madison No. 1 well tied to the total wave field from vertical

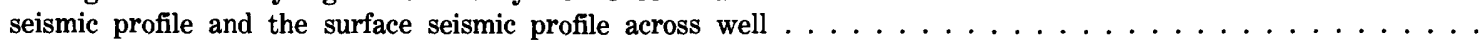

V-11. Plot of stacked, edited raw data from Sam Gary Bell Creek Madison No. 1 well, obtained January 23-February

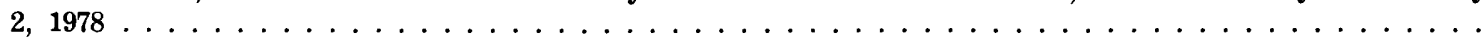

V-12. Plot of stacked, edited raw data from Sam Gary Bell Creek Madison No. 1 well, obtained June 12-19, 1978 .

V-13. Processing flow sheet for the Sam Gary Bell Creek Madison No. 1 well . . . . . . . . . . . . . . . . . . .

V-14. Calculation of the transfer function of the Madison aquifer interval from vertical seismic profile data at the Sam Gary Bell Creek Madison No. 1 well . . . . . . . . . . . . . . . . . . . . . . . . .

V-15. Lithologic and velocity logs of Coronado Collins No. W-1 well tied to the total seismic wave field from vertical seismic

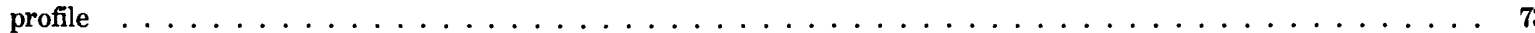

V-16. Edited, static-corrected raw vertical seismic profile data from the Coronado Collins No. W-1 well . . . . . 74

V-17. Processing flow sheet for the vertical seismic profile data from the Coronado Collins No. W-1 well . . . . . 75

V-18. Calculation of the transfer functions of the Madison aquifer interval from vertical seismic profile data at Coronado Collins No. W-1 well . . . . . . . . . . . . . . . . . . . . . . . . . .

V-19. Lithologic and velocity logs of Bechtel ETSI No. 0-1 well tied to the total seismic wave field from vertical seismic profile and the surface seismic profile across well $\ldots \ldots \ldots \ldots \ldots \ldots$

V-20. Sorted raw vertical seismic profile data obtained from the Bechtel ETSI No. 0-1 well vertical seismic profile of

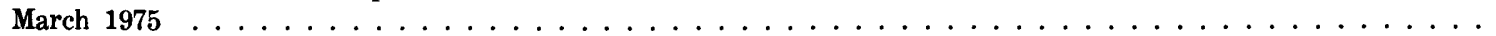

V-21. Sorted raw vertical seismic profile data obtained from the Bechtel ETSI No. 0-1 well vertical seismic profile of

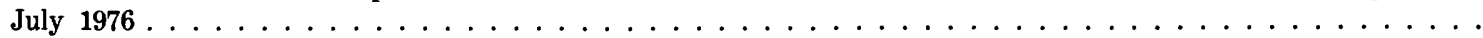

V-22. Downhole and surface recordings from $2,275 \mathrm{ft}$ and $2,250 \mathrm{ft}$, Bechtel ETSI No. $0-1$ well vertical seismic profile of July $1976 \ldots \ldots \ldots \ldots \ldots \ldots$

V-23. Sorted, edited, and stacked raw data, Bechtel ETSI No. 0-1 well, air gun vertical seismic profile of August 1978 . . 81

V-24. Processing flow sheet for the Bechtel ETSI No. 0-1 well vertical seismic profile data obtained August 1978 . . 82

V-25. Calculation of the transfer functions of the Madison aquifer from vertical seismic profile data at the Bechtel ETSI No. $0-1$ well . . . . . . . . . . . . . . . . . . . . . . . . . . . . . .

V-26. Lithologic and velocity logs of Pfister Fee No. 1 well tied to the total seismic wave field from vertical seismic profile

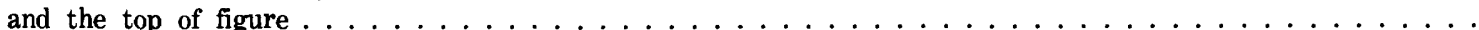

V-27. Stacked, sorted, raw vertical seismic profile data, Pfister Fee No. 1 well . . . . . . . . . . . . . .

V-28. Processing flow sheet for the Pfister Fee No. 1 well . . . . . . . . . . . . . . . . . . . . . .

V-29. Calculation of the transfer functions of the Madison aquifer interval from the vertical seismic profile data at Pfister Fee No. 1 well . . . . . . . . . . . . . . . . . . . . . . . . 


\section{INTRODUCTION}

In this chapter we present the vertical seismic profile data area by area. The acquisition required 10 field trips to six separate areas.

Several of the field acquisition efforts are described in detail in the hope that subsequent workers will profit from our experience. We recognize the fact that under different circumstances, field methods that were not satisfactory to us might yield acceptable results and vice versa.

All the computer processing steps referred to are described in chapter IV. The results of each individual survey will be summarized in chapter VI.

\section{USGS MADISON NO. 1 WELL}

\section{STRATIGRAPHY, WELL HISTORY, AND AQUIFER PROPERTIES}

The U.S. Geological Survey Madison No. 1 well is located in $\mathrm{NE}^{1} / 4 \mathrm{SE}^{1} / 4$ sec. 15 , T. $57 \mathrm{~N}$., R. $65 \mathrm{~W}$., of Crook County, Wyo. The hole was drilled as a control point for regional Paleozoic aquifer studies conducted by the Water Resources Division of the U.S. Geological Survey. The well spuds in the Lower Cretaceous Inyan Kara Group and terminates in Precambrian crystalline rocks. The total depth is $4,355 \mathrm{ft}$. This well contains 20 -in. casing to $331 \mathrm{ft}, 13 \frac{3}{8}$-in. casing to $1,502 \mathrm{ft}, 95 / 8$-in. casing between 1,393 and $2,333 \mathrm{ft}$, and $7 \% / 8$-in. open hole between 2,333 and $4,341 \mathrm{ft}$. The casing is well bonded to the borehole according to the cement-bond log. A generalized lithologic $\log$ with labeled formation tops is illustrated in figure $\mathrm{V}-1$.

The Madison Group is about $745 \mathrm{ft}$ thick and is bounded unconformably by the Ordovician Stony Mountain Formation at the base and by the PennsylvanianMississippian lower part of the Minnelusa Formation at the top (fig. V-1). About sixty percent of the Madison Group found in this well is dolomite and the remainder is composed of limestone and minor amounts of anhydrite and shale.

The Red River Formation is about $470 \mathrm{ft}$ thick. It rests conformably on the Winnipeg Formation and is overlain unconformably by the Stony Mountain Formation (fig. V-1).

Radioactive tracer and spinner surveys indicate that nearly 60 percent of the 520 -gal/min water flow from the Madison aquifer is from the Red River Formation (R. K. Blankennagel, oral. commun., 1977; fig. V-1). The shut-in pressure is 48 psi (pounds per spare inch). The majority of the Red River Formation water appears to be contributed by zones of vuggy, fine- to medium-grained crystalline dolomite. Water-flow data further indicate that $50-65$ percent of the water from the Madison Group is contributed by the Mission Canyon Limestone. Producing zones in the Mission Canyon Limestone are comprised largely of vuggy crystalline dolomite units that we believe have been brecciated extensively by the post-depositional removal of adjacent evaporite beds (chapter II).

For additional data on the USGS Madison No. 1, the reader is referred to the report by Blankennagel and others (1977).

\section{VERTICAL SEISMIC PROFILE DATA ACQUISITION}

The USGS Madison No. 1 was profiled on October 13 and 14, 1976, from 4,100-3,500 ft and on January 19-27, 1977, from 3,500-382 ft. During the October shooting episode, time was at a premium because the drilling rig was set up over the hole. Formation testing had not been completed; consequently, the possibility existed that the well would be plugged back to as far as $3,500 \mathrm{ft}$. The well was profiled from $4,100-3,500 \mathrm{ft}$ only, to save rig time but still insure that the entire well would be surveyed eventually.

Three source offset distances of $400,2,600$, and 7,800 $\mathrm{ft}$ were used. Twenty shot holes were drilled at the 7,800 -ft offset source location. Ten were spaced evenly on an inner circle of 65 -ft radius; ten more were spaced evenly on a concentric outer circle of $100-\mathrm{ft}$ radius. A source monitor detector was placed at the bottom of a 310 -ft hole located at the center of the circles. Holes on the inner circle only were used in October. Ten to twenty pounds of explosives were required at the $7,800-\mathrm{ft}$ offset location in order to record reasonable seismic amplitudes in the USGS Madison No. 1. Source depths ranged from 160-138 ft.

At the 2,600-ft offset location, 10 holes were spaced on a circle of $60-\mathrm{ft}$ radius. A source monitor detector was $235 \mathrm{ft}$ deep in a hole at the center of the circle. Source depths ranged from $205-154 \mathrm{ft}$. At the $400-\mathrm{ft}$ offset location, 16 holes were drilled on two concentric circles of radii 20 and $50 \mathrm{ft}$. A source monitor detector was placed at the bottom of a 265 -ft hole at the center of the circles. Only the inner circle shot holes were used in October. Explosive charge size ranged from 5-21/2 $\mathrm{lb}$ (pound).

Seismic recording services and shooting services were provided by Triangle Geophysical Company, using a Texas Instrument D.F.S. IV instantaneous floatingpoint recording system. In the January shooting episode, surface geophone recording stations were laid out on the ground in a line between the well and the $7,800-\mathrm{ft}$ source location at $200-\mathrm{ft}$ intervals. Surface recording and downhole recording on 24 stations were performed; the surface coverage was varied during shooting to obtain data from all 40 stations. 


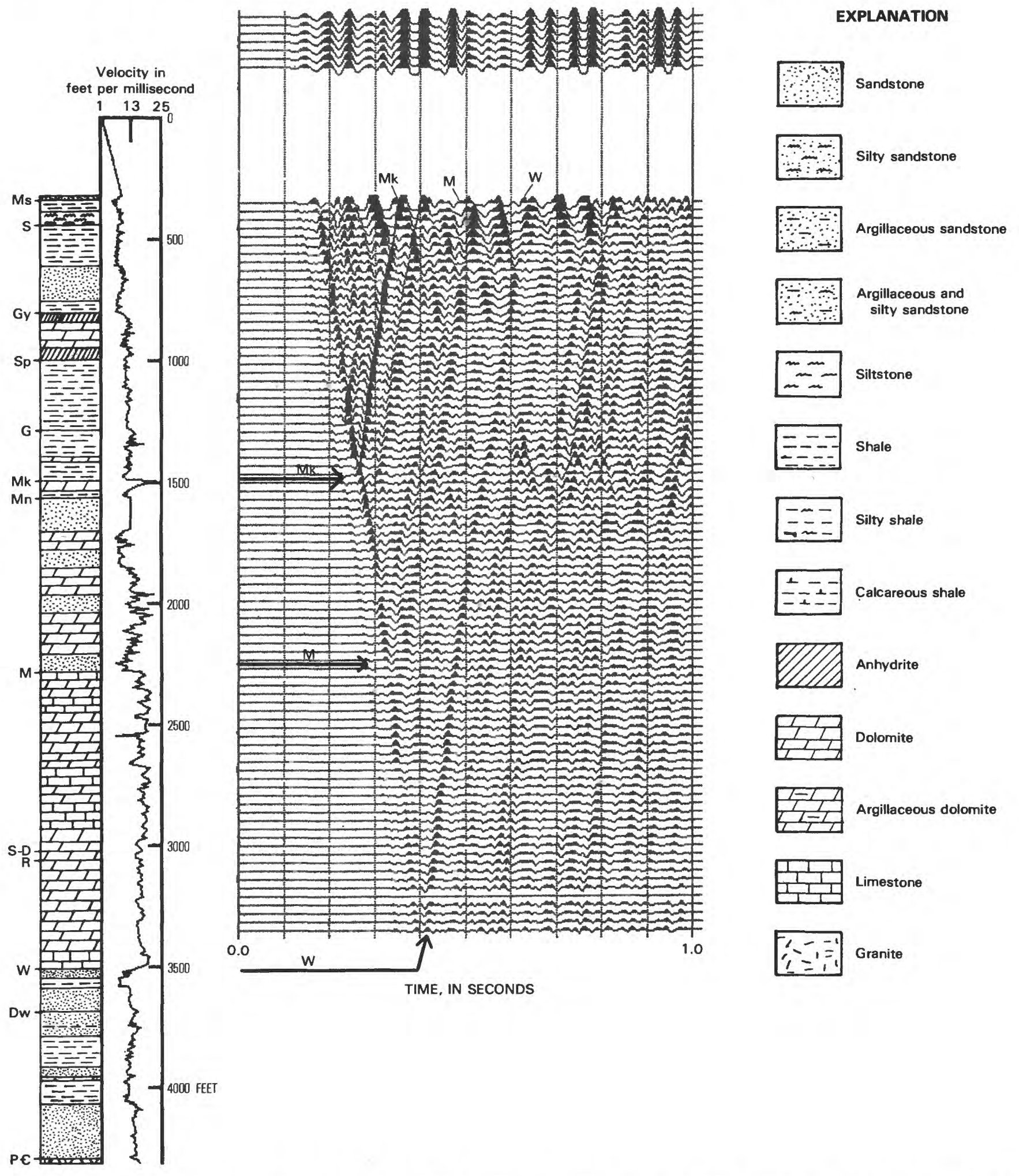

FIGURE V-1,-Lithologic and velocity logs of USGS Madison No. 1 well, Wyoming, tied to the total seismic wave field from the vertical seismic profile and the surface seismic profile across well (top of figure). Ms, Morrison Formation; S, Sundance Formation; Gy, Gypsum Springs Formation; Sp, Spearfish Formation; G, Goose Egg Formation; Mk, Minnekahta Limestone; Mn, Minnelusa Formation; M, Madison Group; S-D, Silurian and Devonian rocks undifferentiated; R, Red River Formation; W, Winnipeg Formation; Dw, Deadwood Formation; Pc, Precambrian rocks. Velocity is in feet per millisecond (ft/ms). 
The downhole detector was a three-component unit furnished by Amoco Production Company. A springloaded locking device was provided by Seismic Reference Service Company of Tulsa, Okla.

During the October shooting episode, first arrivals were observed on the field monitor recordings at all levels for all source offsets. Events other than first arrivals were difficult or impossible to see. On the first pass up the hole, the 400 - and 2,600-ft offset sources were energized alternately to save rig time. Coordination among source holes, recording equipment, and wire line operator was difficult, in spite of good voice radio communication. Much of the shooting was done at night, which compounded the coordination problem.

During both the October and the January shooting episodes, a great deal of difficulty was encountered in controlling the source waveforms. The shotholes frequently plugged back, forcing shots at a variety of source depths and, therefore, in a variety of rock media. Cap wire frequently "balled up" in the source holes, but often this was not detected until an attempt was made to shoot the hole subsequently at the original depth. Often this problem went completely unnoticed. Many of the shothole bridges and plugs were cleared on subsequent shots, so subsequent shots were sometimes placed deeper than earlier ones. In addition to all these problems, poor light or total darkness made work at the shothole uncertain and hazardous.

Because plugging often forced early abandonment of the holes, a shothole drill was used to drill new holes and to clean out plugged holes during the recording operations. The drilling operation often conflicted with the shooting operations, causing overall coordination of the effort to deteriorate. The drilling-shooting operation was impeded by water from "hole blow," which eventually turned the entire source-hole areas into a morass of mud. This mud caused the drill to stick occasionally and greatly impeded the mobility of the shothole crew. The temperature was below $0^{\circ} \mathrm{F}$ during the January operation, which caused additional hardship and loss of efficiency on the part of shothole personnel, particularly when holes blew and sprayed freezing mud about.

As a result of these field difficulties, many shot depths were recorded incorrectly. On some occasions, the uphole detector was disconnected inadvertently or moved to the wrong shothole. For these reasons, the uphole times recorded were unreliable.

Many irreducible static errors were recorded. Source wavelets varied drastically, both in amplitude and shape. Shot-depth information occasionally was lost irretrievably. The explosive source data at the USGS Madison No. 1 has been difficult to process and to interpret quantitatively.
At the conclusion of the January shooting episode, an additional survey was made using a Bolt LSS -3 surface air gun at the 400 -ft offset location. Time constraints forced us to record only at this one offset location and only from 3,500 $\mathrm{ft}$ to the surface. The surface air-gun data were lower in frequency and weaker in amplitude, but vastly better than the explosives data in overall quality. The source waveform was nearly identical on successive "shots" and the source location remained the same, avoiding static errors. The weak signal was compensated for by "shooting" repeatedly at each level and summing.

The surface source operation began at about 6:00 p.m. and was completed about 4:00 a.m. the following morning. At about midnight, a heavy blizzard started, accompanied by extreme cold (about $-17^{\circ} \mathrm{F}$ ) and heavy snow. At about 2:00 a.m., the surface seismic source began to freeze up and its output amplitude gradually decreased, resulting in extremely weak signal. Even so, the source waveform remained nearly constant.

The surface source data proved to be of good quality. All the USGS Madison No. 1 data shown in this report were acquired by the air gun. The relatively low frequencies obtained were a good trade-off for greatly improved data quality.

In the cased portion of the well, considerable difficulty was encountered in obtaining a lock or clamp to the hole. Apparently the spring-loaded locking arm exerts insufficient force against the wall of the hole to bite into steel casing. Tool slippage with severe "creep noise" resulted. A good lock was obtained at casing joints and usable data were obtained there. The procedure caused difficulties in processing, however, because the casing joints are spaced unevenly, with an average spacing of about $31 \mathrm{ft}$. Uniform sampling spacing is highly desirable for velocity filtering.

The three-component Amoco tool failed during the last episode and was replaced with a vertical-component Triangle Geophysical tool, manufactured by Southwestern Industrial Electronics Corporation.

No use has been made yet of the horizontal component data or of the long offset data from the USGS Madison No. 1 well. The data were of such generally poor quality that we have devoted our efforts to the much better quality vertical component near offset data obtained at the USGS Madison No. 1 and elsewhere.

\section{VERTICAL SEISMIC PROFILE DATA PROCESSING}

The raw VSP data plots from the 400-ft offset explosive source are shown in figure V-2. Because of the recording difficulties mentioned in the previous section, 


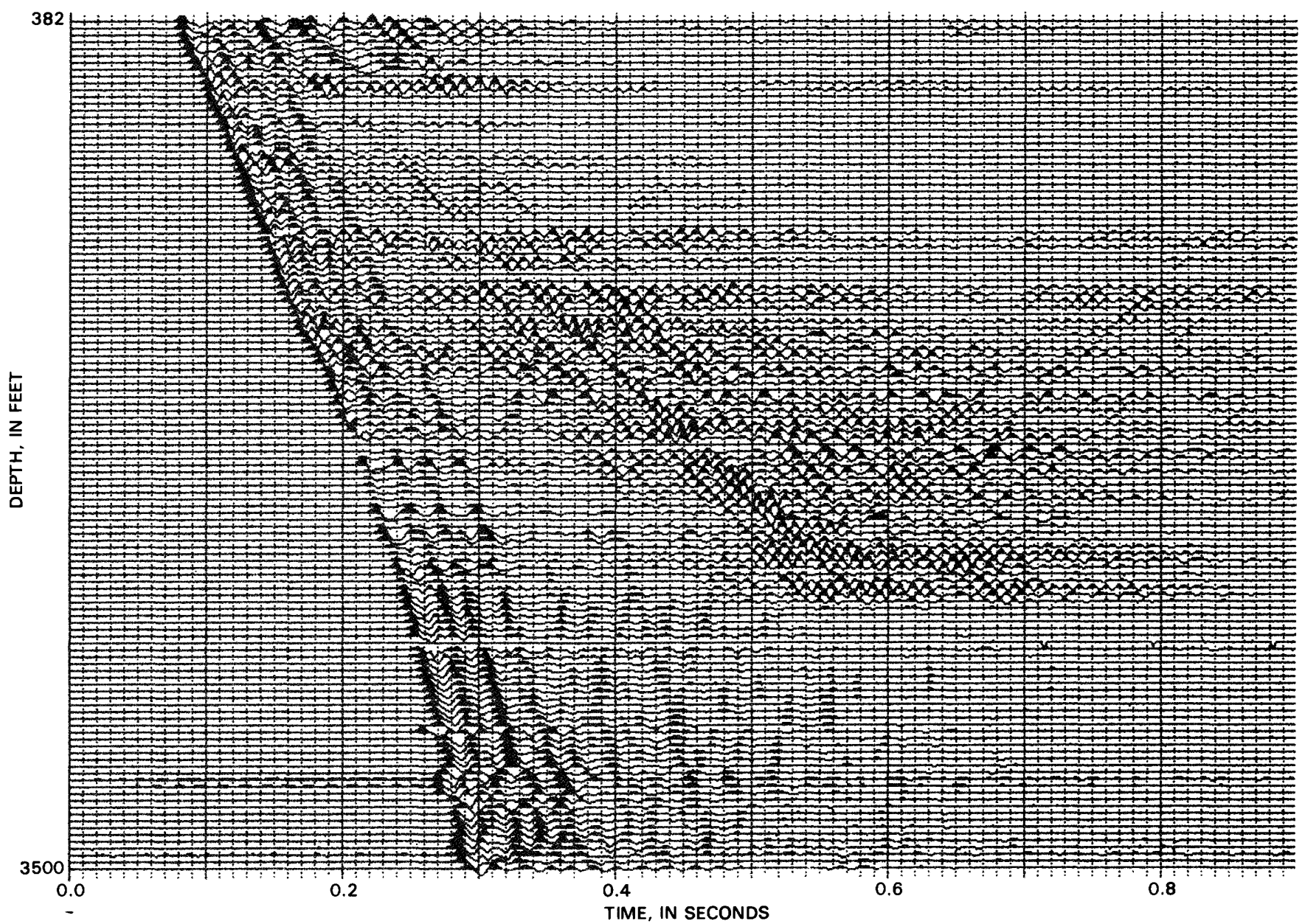

Figure V-2.-Raw vertical seismic profile data recorded at the USGS Madison No. 1 well, Wyoming. An explosive source was used with a 440 -ft offset.

these data have not been processed extensively or interpreted.

The raw, surface air-gun data are shown in figure $\mathrm{V}-3$. The lower frequency of the source is apparent when figure $\mathrm{V}-3$ is compared with figure $\mathrm{V}-2$. The processing flow sheet for the air-gun data is shown in figure $\mathrm{V}-4$. The final processing output for interpretation purposes includes the total wave field superimposed with a five-fold increase in upward-traveling wave-field amplitude (fig. V-1).

As an additional aid to interpretation, the time-domain transfer function for seismic energy reflected off the top of the Madison Group was calculated, and a Madison-Red River acoustic impedance log was estimated from this function. The frequency amplitude spectrum of the transfer function was estimated also. These results are shown on figure $\mathrm{V}-5$. The transfer function was obtained as follows:

1. At a level $200 \mathrm{ft}$ above the top of the Madison, a three-trace composite of both the upgoing and down- going wave field was made to enhance signal-to-noise ratio.

2. The Kalman technique was used to obtain the time-domain transfer function after applying an 18-90 $\mathrm{Hz}$ band-pass filter.

3. The impedance function was then calculated using the method described elsewhere in this report (chapter IV).

\section{IDENTIFICATION OF THE STRATIGRAPHIC HORIZONS ON THE VERTICAL SEISMIC PROFILE}

Several major coherent reflected events can be tied to the lithologic log. Three such ties are shown in figure $\mathrm{V}-1$ : The Winnipeg Formation, at 3,500 ft; the top of the Madison Group, at about 2,200 ft; and the top of the Minnekahta Limestone, at $1,500 \mathrm{ft}$. The tie for these three horizons to the surface seismic profile, run across the USGS Madison No. 1 well (Ryder and others, 1981), is shown at the top of figure V-1. 


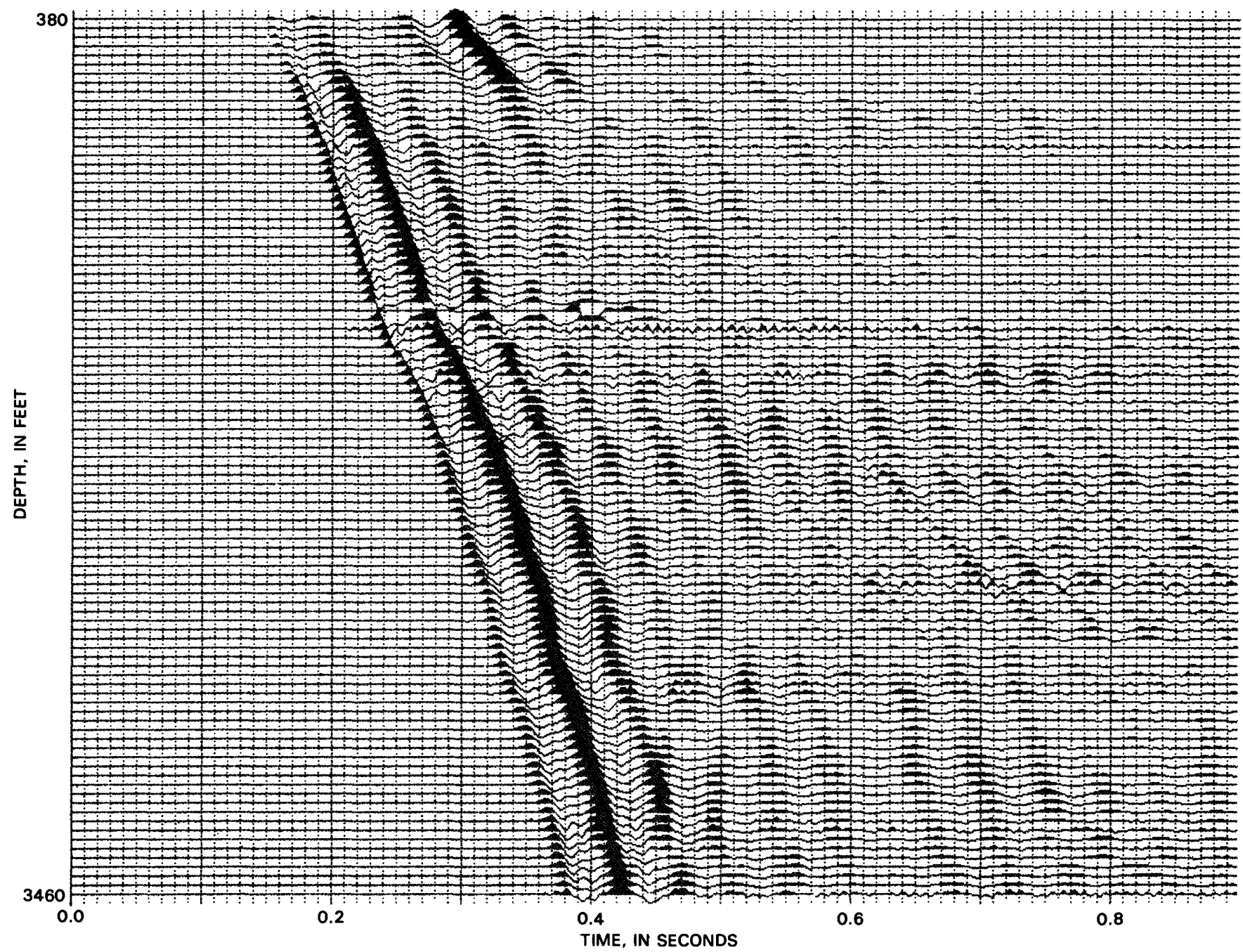

FiguRE V-3.-Raw vertical seismic profile data recorded at the USGS Madison No. 1 well, Wyoming. A Bolt LSS-3 surface air gun was used for the seismic energy source.

\section{USGS MADISON NO. 2 WELL}

\section{STRATIGRAPHY, WELL HISTORY, AND AQUIFER PROPERTIES}

The USGS Madison No. 2 well, located in SE1/4 SE $1 / 4$ sec. 18, T. 1 N., R. 54 E. of Custer County, Mont., was drilled as a control point for regional Paleozoic aquifer studies of the U.S. Geological Survey. The well spuds in the Hell Creek Formation of Late Cretaceous age and ends in Precambrian crystalline rocks. The total depth is $9,394 \mathrm{ft}$. The hole contains 20 -in. casing to $407 \mathrm{ft}, 133 / 8$-in. casing to $4,662 \mathrm{ft}, 95 / 8$-in. casing from 4,519 to $6,487 \mathrm{ft}$, and $81 / 2$-in. open hole between 6,487 and total depth. The casing is well bonded to the borehole according to the cement-bond log. A generalized lithologic log, with labeled formation tops, is shown in figure $\mathrm{V}-6$.
The Madison Group is about $1,185 \mathrm{ft}$ thick and is bounded unconformably by the Devonian Jefferson Group at the base and the Pennsylvanian-Mississippian Amsden Formation at the top (fig. V-6). Limestone, dolomite, and anhydrite constitute, respectively, about 76 percent, 18 percent, and 6 percent of the Madison Group at this locality.

The Red River Formation is about $450 \mathrm{ft}$ thick. It rests conformably on the Winnipeg Formation and is overlain unconformably by the Stony Mountain Formation (fig. V-6). Here, the Red River Formation is composed of about 30 percent dolomite and 70 percent limestone.

In marked contrast to the USGS Madison No. 1 well, this water well only flows about $48 \mathrm{gal} / \mathrm{min}$ from the Madison and associated aquifers. The wellhead pressure attains 300 psi. A radioactive tracer survey 
DEMULTIPLEXING

EDIT, SORT, STACKING

FREQUENCY ANALYSIS AND BAND-PASS FILTERING$8 / 15-80 / 100 \mathrm{~Hz}$

MONITOR PHONE SHAPING FILTER DESIGN AND APPLICATION

DYNAMIC TIME CORRECTION

MULTICHANNEL VELOCITY FILTERING

GAIN APPLICATION $-\mathrm{T}^{2}$

DESIGN AND APPLICATION DOWNGOING WAVE TRAIN DECONVOLUTION-Deconvolution operator was designed at $1055 \mathrm{ft}$, and band-pass filtering $(8 / 14-64 / 80 \mathrm{~Hz})$ was applied after deconvolution

CUMULATIVE SUM FOR UPGOING WAVE

MERGE DOWNGOING AND UPGOING WAVES-Downgoing +upgoing $\times 5$

ESTIMATION TRANSFER FUNCTION

INVERSE-Impedance log estimation

FiguRe V-4.-Processing flow sheet for the data shown in figure $\mathrm{V}-3$. suggested that just more than 50 percent of the total flow was coming from the Red River Formation ( $R$. K. Blankennagel, written commun., 1977; fig. V-6). An obstruction in the hole at $7,875 \mathrm{ft}$ precluded the exact location of the water-producing zones in the Red River Formation, but most likely they are coincident with the low-velocity, vuggy dolomite zones between 8,150 $8,175 \mathrm{ft}$ and $8,210-8,242 \mathrm{ft}$. Of the meager water production from the Madison Group, about 70 percent originates from the upper part of the Lodgepole Limestone and the middle and lower parts of the Mission Canyon Limestone (fig. V-6).

Additional data on the USGS Madison No. 2 can be obtained from the report by Brown and others (1978).

\section{VERTICAL SEISMIC PROFILE DATA ACQUISITION}

The USGS Madison No. 2 was profiled vertically August $3-5,1977$, from $8,300-2,750 \mathrm{ft}$. The $8,300-$ to $3,800-$ $\mathrm{ft}$ section was profiled at 25 - $\mathrm{ft}$ intervals, the 3,800 - to 1,500 - $\mathrm{ft}$ section at 40 - $\mathrm{ft}$ intervals, and the 1,500- to 750$\mathrm{ft}$ section at $50-\mathrm{ft}$ intervals. A 20 - to 25 - $\mathrm{ft}$ interval was desired, but time and money constraints forced us to increase the interval in order to complete the survey.

Six auxiliary holes were drilled to a depth of $160 \mathrm{ft}$, offset from the well about $200 \mathrm{ft}$. Severe hole caving was encountered due to the loose gravelly nature of the near-surface at this location. Casing was required to prevent hole collapse. These holes were intended originally for use as source holes for downhole air guns.

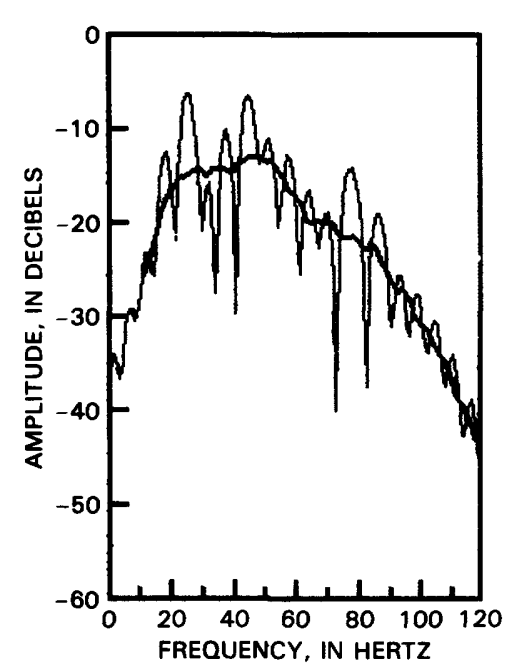

A
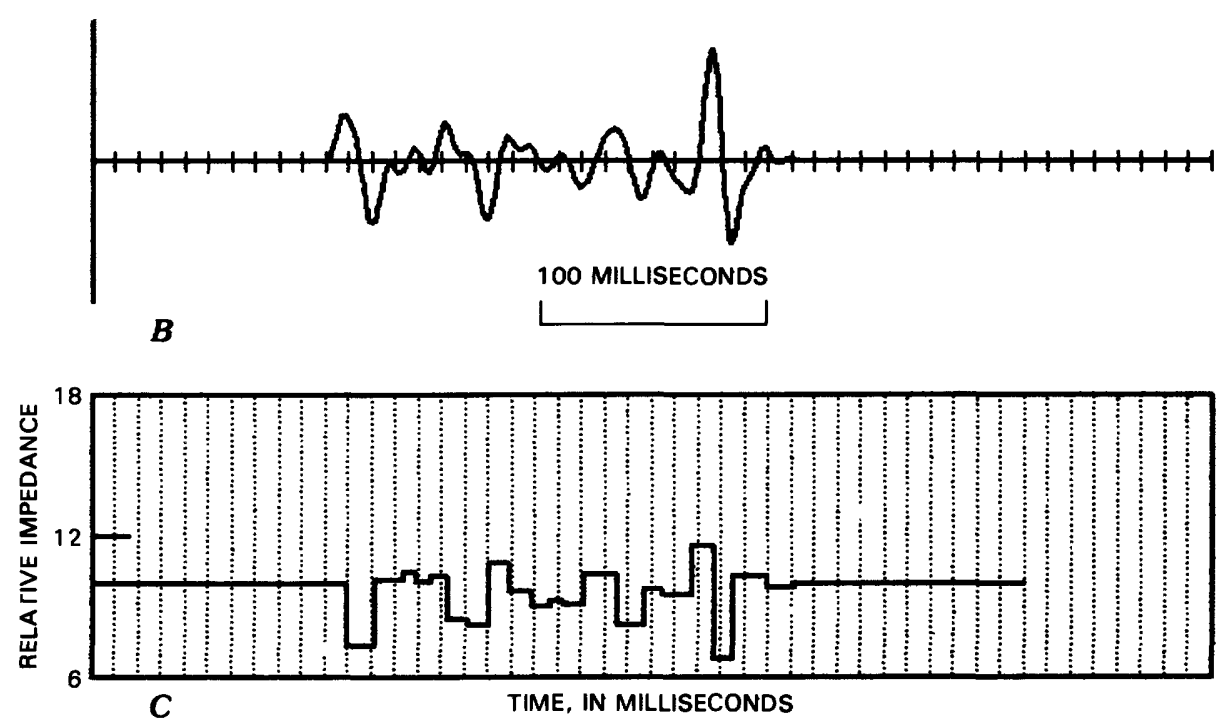

FIGURE V-5.-Calculation of the transfer functions of the Madison and associated aquifers from vertical seismic profile data at the USGS Madison No. 1 well, Wyoming. $A$, Amplitude spectrum of the transfer function; $B$, transfer function; $C$, estimated acoustic impedance log. 
Velocity in

feet per millisecond

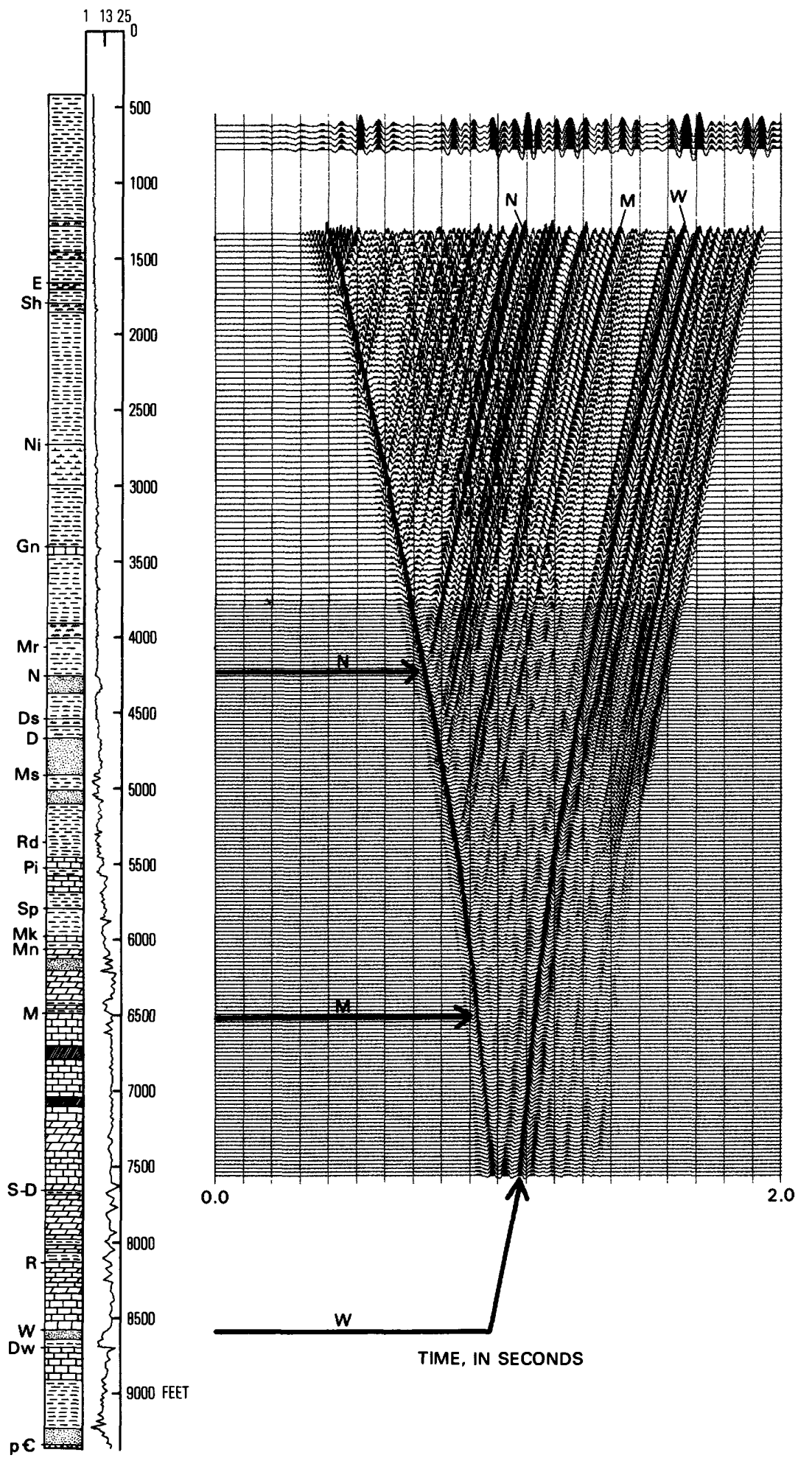

EXPLANATION
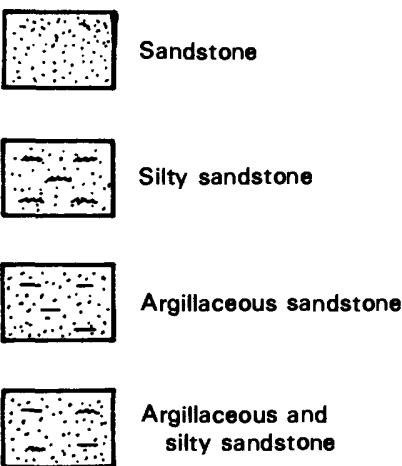

Argillaceous and

silty sandstone

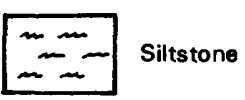

=- $=$ Shele

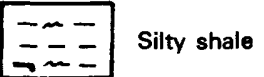

ニேュニ Calcareous shale

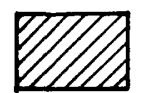

Anhydrite

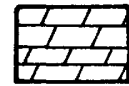

Dolomite

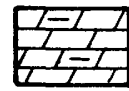

Argillaceous dolomite

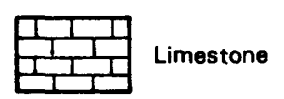

$F=-1=19$ Granite

FIGURE V-6.-Generalized lithologic and velocity logs of the USGS Madison No. 2 well, Montana, tied to the total wave field from the vertical seismic profile and the surface seismic profile across well (top of figure). E, Eagle Sandstone; Ni, Niobrara Formation; Gn, Greenhorn Formation; Mr, Mowry Shale; N, Newcastle Sandstone; Ds, silt of Cretaceous age (Dakota silt of oil industry usage); I, Inyan Kara Group equivalent; Ms, Morrison Formation; Rd, Rierdon Formation; Pi, Piper Formation; Sp, Spearfish Formation; Mk, Minnekahta Limestone; Mn, Minnelusa Formation; M, Madison Group; S-D, Silurian and Devonian rocks undifferentiated; R, Red River Formation; W, Winnipeg Formation; Dw, Deadwood Formation; Pc, Precambrian rock. Velocity is in feet per milliseconds ( $\mathrm{ft} / \mathrm{ms})$. 


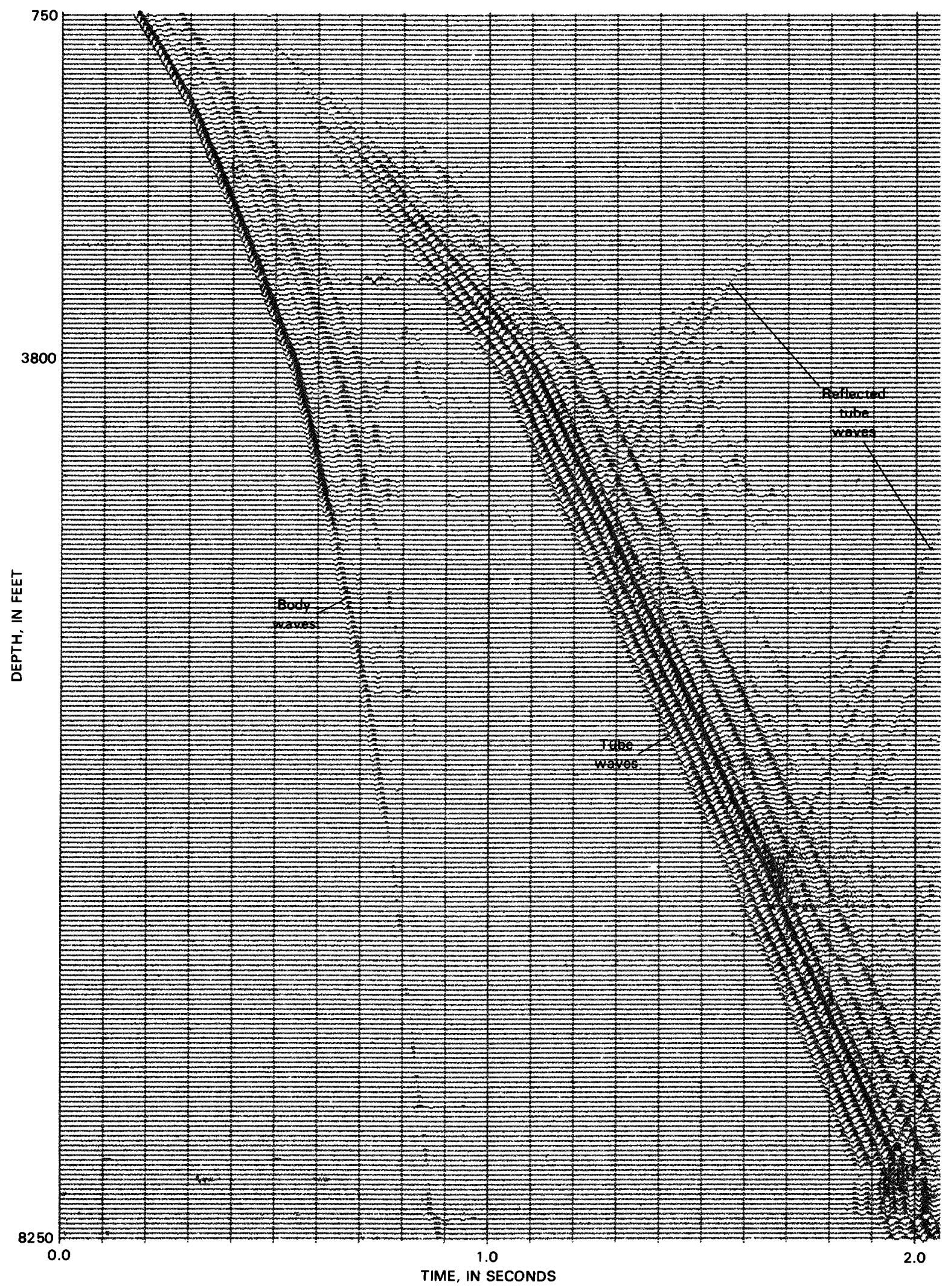

FIGURE V-7.-Summed raw vertical seismic profile data from the USGS Madison No. 2 well, Montana. 
Electromechanical difficulties with the air guns, shortage of high-pressure gas, and time constraints all precluded using the downhole guns. One of the holes was used for the source monitor detector.

A single Bolt LSS-3 land seismic source, located directly above the buried source monitor detector, was used as the energy source. Because there was considerable surface attenuation and the well was deep, as many as 25 "pops" were recorded on each level. Subsequent summing then yielded good quality recordings. The recording operation was interrupted once due to a ruptured diaphragm on the LSS-3. Some difficulty was encountered occasionally when, after repeated shooting, the source gun assembly dug inself into the ground so far that the weight of the source gun truck could not be brought to bear on the source gun assembly. The source then had to be moved a few feet. Several firings of the gun at the new location, to compact the soils, were then required to stabilize the source waveform. Even so, small changes in source waveform could be observed as a result of this relocation.

Severe wind noise was encountered occasionally at this location. A mast had been erected over the well to facilitate operating the tool. Noise from the swaying mast and wind-exposed wireline apparently traveled down the wireline and interfered with the recording operation. As we shall see in the following section, severe tube noise was recorded. These wave trains were by far the largest amplitude events, at depth. Fortunately, the tube-wave arrivals were separated considerably in time from the body waves of interest, at least in the lower part of the well. Considerable useful information thus was obtained in spite of the high-amplitude tube-wave interference.

\section{VERTICAL SEISMIC PROFILE DATA PROCESSING}

The summed data are shown in figure V-7. The data traces have been normalized to the highest amplitude event on each trace and then plotted with time-invariant gain. Because the tube noise is confined to the well bore, it does not spread spherically. Below $3,700 \mathrm{ft}$, the noise becomes the highest amplitude event-higher even than the body-wave first arrival from the source. Reflected tube waves can be seen also. These modes were of such high amplitude that they simply were excised from the data at this point.

The apparent velocity change at $3,800 \mathrm{ft}$ is a result of the modified sampling interval.

A summary of the data processing steps is shown in figure $\mathrm{V}-8$. Note that velocity filtering was used twice-both before and after deconvolution.
DEMULTIPLEXING

EDIT, SORT, STACKING

FREQUENCY ANALYSIS AND BAND-PASS FILTERING10/15-80/100 Hz

MONITOR PHONE SHAPING FILTER DESIGN AND APPLICATION

MULTICHANNEL VELOCITY FILTERING - First pass

DESIGN AND APPLICATION DOWNGOING WAVE TRAIN DECONVOLUTION-Deconvolution operator was designed at $1300 \mathrm{ft}$, and band-pass filtering $(10 / 15-80 / 100 \mathrm{~Hz})$ was applied after deconvolution

MULTICHANNEL VELOCITY FILTERING - Second pass

GAIN APPLICATION-T ${ }^{2}$

CUMULATIVE SUM FOR UPGOING WAVE

MERGE DOWNGOING AND UPGOING WAVES-Downgoing +upgoing $\times 5$

ESTIMATION TRANSFER FUNCTION

INVERSE-Impedance log estimation

Figure V-8.-Data processing flow sheet for the vertical seismic profile from the USGS Madison No. 2 well, Montana.

The processing results are summarized in figure $\mathrm{V}-6$, in which the downgoing waves have been combined with a five-fold amplification applied to the upgoing wave trains. Reflections are clearly apparent here and the relationship to the downward-traveling wave trains is evident.

A reflection transfer function was calculated for a point $150 \mathrm{ft}$ above the top of the Madison. It is shown in figure V-9. Because nearly all the signal was between 24 and $85 \mathrm{~Hz}$, a corresponding band-pass filter was used before the transfer function was calculated. The transfer function spectrum shown in the figure is reliable only within this frequency range.

\section{IDENTIFICATION OF STRATIGRAPHIC HORIZONS ON THE VERTICAL SEISMIC PROFILE}

In figure $\mathrm{V}-6$, a large number of coherent upwardtraveling events can be tied to the lithologic log. The ties for three such events-the Winnipeg Formation (W), the top of the Madison Group (M), and the Newcastle Sandstone $(\mathrm{N})$-are indicated in the figure. In addition, the ties to a surface profile run across the USGS Madison No. 2 well are shown across the top of the figure (Balch and others, 1981). 


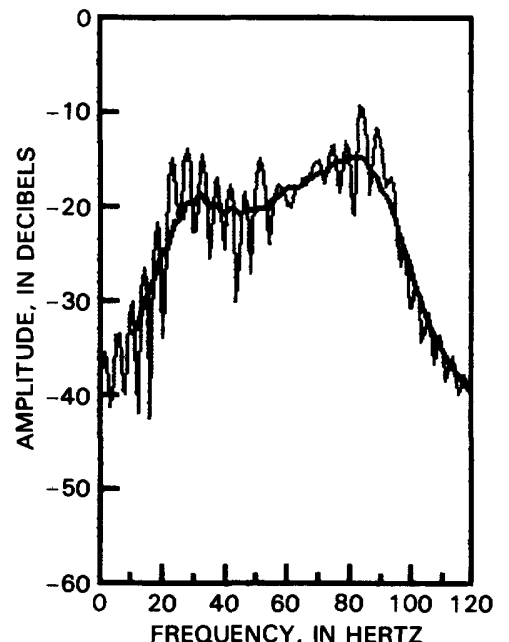

$\boldsymbol{A}$
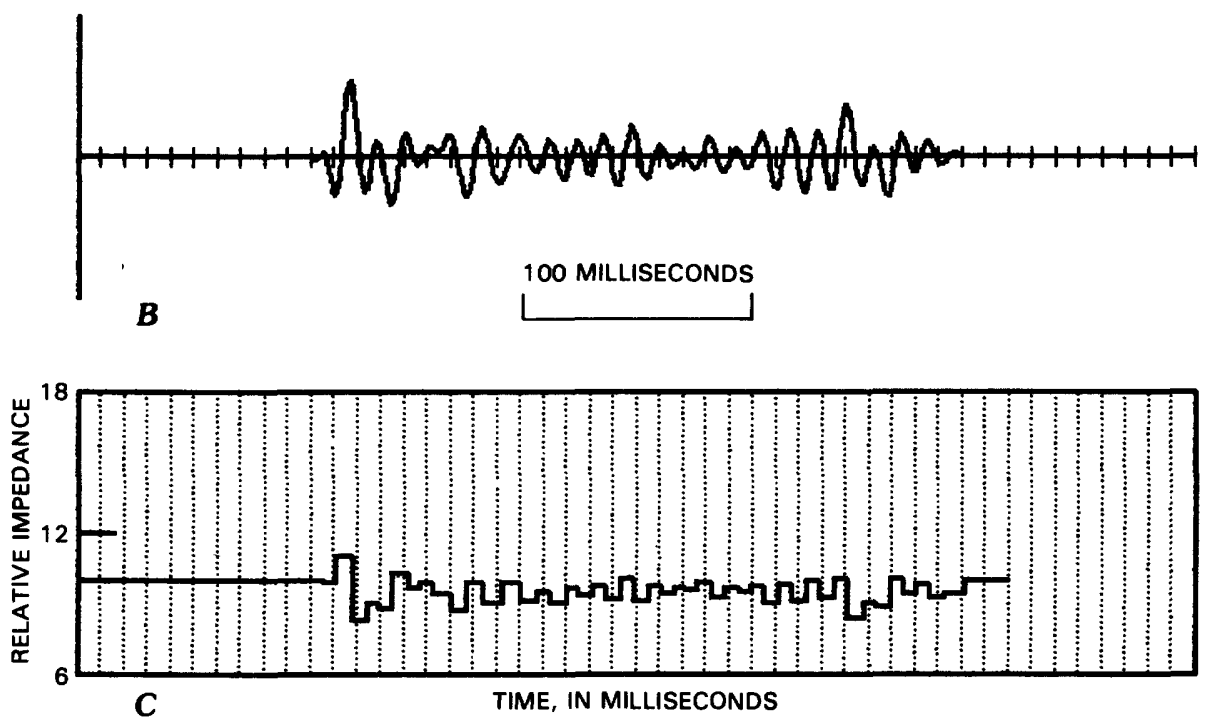

FIGURE V-9.-Calculation of the transfer functions of the Madison and associated aquifers from vertical seismic profile data at the USGS Madison No. 2 well, Montana. $A$, Amplitude of the transfer function; $B$, time-domain transfer function; $C$, estimated acoustic impedance log.

\section{SAM GARY BELL CREEK MADISON NO. 1 WELL \\ STRATIGRAPHY, WELL HISTORY, AND AQUIFER PROPERTIES}

The Sam Gary Bell Creek Madison No. 1 is located in $\mathrm{NW}^{1 / 4} \mathrm{SW}^{1 / 1} 4$ sec. 27, T. 8 S., R. $54 \mathrm{E}$. of Powder River County, Mont. The well was drilled to supply water for secondary-recovery operations in the Bell Creek oil field. The well spuds in the Hell Creek Formation of Late Cretaceous age and bottoms about 300 $\mathrm{ft}$ into Ordovician Red River Formation. The total depth is $8,011 \mathrm{ft}$. The hole is cased with $13 \%$-in. pipe to $164 \mathrm{ft}, 85 / 8$-in. pipe to $4,393 \mathrm{ft}$, and $51 / 2$-in. pipe from 3,759 to $8,000 \mathrm{ft}$. A bridge plug is located at $7,629 \mathrm{ft}$. The casing is well bonded to the borehole except for one gap in the cement at about 4,393 ft. A generalized lithologic log, with labeled formation tops, is shown on figure V-10.

The Madison Group is about $775 \mathrm{ft}$ thick and is bounded unconformably by the Devonian Jefferson Group at the base and the Pennsylvanian-Mississippian Amsden Formation at the top (fig. V-10). Based on data from the adjacent Gulf Boyle No. 1, (sec. 4, T. 8 S., R. 52 E.), the Red River Formation in the Bell Creek field is between 440 and $450 \mathrm{ft}$ thick. Presumably, the formation rests conformably on the Winnipeg
Formation and is overlain unconformably by the Stony Mountain Formation (fig. V-10).

About $250 \mathrm{gal} / \mathrm{min}$ of water flow is obtained from a perforated and acidized interval between 6,960 and $7,160 \mathrm{ft}$ in the Mission Canyon Limestone (fig. V-10). When pumped, the interval yields about $350 \mathrm{gal} / \mathrm{min}$. The shut-in wellhead pressure is 90 psi. The waterproducing zone corresponds to a low-velocity zone that we believe is comprised of collapse-brecciated, vuggy crystalline dolomite. The same zone flows more than $890 \mathrm{gal} / \mathrm{min}$ and pumps at more than $1,000 \mathrm{gal} / \mathrm{min}$ in the adjacent Sam Gary No. 2 Madison water well (sec. 21, T. 8 S., R. 54 E.). Minimal water flow was recorded from the Red River Formation when tested.

\section{VERTICAL SEISMIC PROFILE DATA ACQUISITION}

The Sam Gary Bell Creek Madison No. 1 well was profiled January 23-February 2, 1978, and again in June 1978. On both occasions, digital recording services, wireline service, and the downhole seismic detector were provided for under contract by Birdwell Division, Seismograph Service Corporation. Four LSS-3 land air guns were furnished by Bolt Associates Incorporated. 
Velocity, in

feet per millisecond

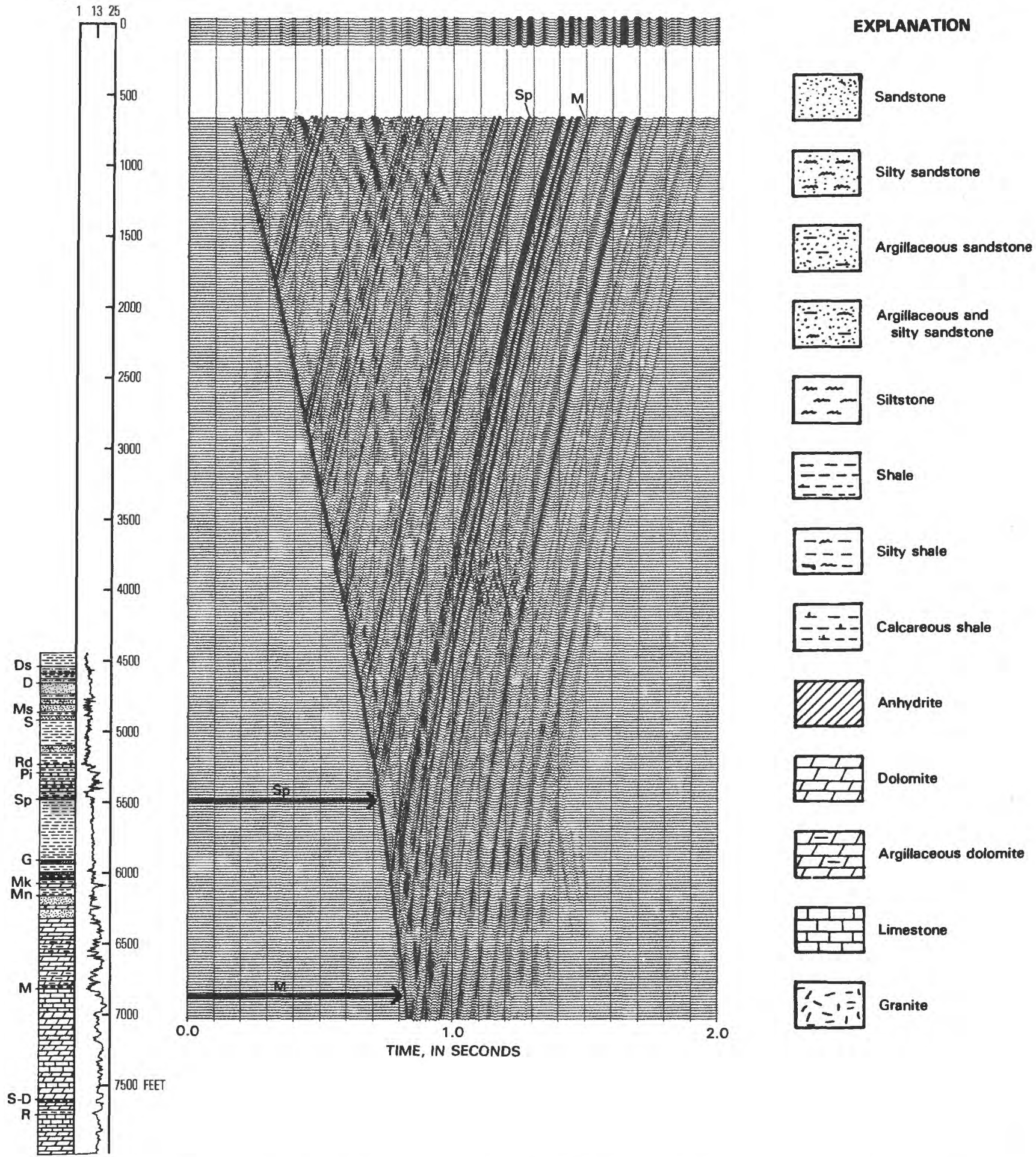

Figure V-10.-Lithologic and velocity logs of Sam Gary Bell Creek Madison No. 1 well, Montana, tied to the total wave field from the vertical seismic profile and the surface seismic profile across well (top of figure). Ds, silt of Cretaceous age (Dakota silt of oil industry usage); I, Inyan Kara Group equivalent; Ms, Morrison Formation; S, Sundance Formation; Rd, Rierdon Formation; Pi, Piper Formation; Sp, Spearfish Formation; G, Goose Egg Formation; Mk, Minnekahta Formation; Mn, Minnelusa Formation; M, Madison Group; S-D, Silurian and Devonian rocks undifferentiated; R, Red River Formation. Velocity is in feet per millisecond (ft/ms). 
Severe cold weather, falling snow, blowing snow, and occasional moderate winds greatly impeded the January operation. The windchill factor was occasionally $-40^{\circ} \mathrm{F}$, and $-10^{\circ} \mathrm{F}$ was quite common. Mechanical equipment left at the site overnight rarely could be started up the following day. As a result, all moveable equipment had to be garaged overnight. The wireline truck could not be moved once it was set up over the well, so it was left running night and day.

Electric power to the well site was inadequate and portable electric generators were required. The generators in the wireline truck burned out early in the field trip, probably due to the severe cold, and could not be repaired.

A lubricator was rigged to control water flow from the well, but lubricator seal pressure had to be reduced when moving the tool. Water leaking from the lubricator quickly froze and coated the entire wellhead area and all equipment near it with ice. This made all wellhead operations slow and hazardous.

The digital recording equipment was mounted in a "doghouse" which in turn was mounted on a small trailer. The doghouse was heated inadequately and the instruments were plagued with a never-ending series of component failures, mechanical and electrical. Most of these failures were attributable, directly or indirectly, to the severe cold. On one occasion, spare replacement equipment had to be shipped to the site from Birdwell headquarters in Tulsa, causing a lost day. On February 1, the recording instruments totally failed; the trip was aborted.

The surface air guns also were plagued with coldweather problems. Bolt Associates had rigged tarpaulins to cover the units, with gas heaters underneath to keep the equipment warm. The heaters were inoperable most of the time and Bolt rarely was able to rig the heavy tarpaulins properly because the units are relatively large and the wind was blowing frequently. The U.S. Geological Survey made arrangements with Gary Production Company, operator of the Bell Creek oil field, to garage the units at night. However, Bolt still was unable to provide adequate air-gun service during the day. Moisture, squeezed out of the air during compression, accumulated in valves and restricted air passages and froze, causing the valves to malfunction. Moisture escaping from the air guns during firing froze on the exhaust air vents and plugged them. Compressor motors failed occasionally and could not be restarted without returning the units to the garage. For all these reasons, the units had to be connected and disconnected to the firing circuitry frequently, and we were hampered with broken connections, broken connectors, and snow and ice in plugs and connectors. It was rarely possible to have more than one of the four units operating at one time. The entire operation was delayed frequently because not even one unit was operable. These delays sometimes caused the wireline to freeze tight at the wellhead causing further delays after an air gun was repaired.

Frequent relocations of the source(s) resulted from the numerous malfunctions and caused excessive waveform changes. Frequent lack of multiple sources resulted in extremely weak signal.

Ultimately, Ed Mazies and Associates of Calgary provided assistance to Bolt Associates in maintaining the air guns. They found that large propane torches were helpful in overcoming the moisture freezing problems.

The extreme cold and long hours in the field affected personnel efficiency as well as the equipment. For example, much of the equipment repair work could not be done with heavy gloves or mittens on. Yet the cold weather limited work in the field without gloves to half a minute or so. The digital recording crew especially was affected adversely because they came to the field from Houston without proper cold weather geareither for themselves, their equipment, or their vehicles.

For all the reasons given, the January data proved to be virtually useless; the well had to be reprofiled in June. Severe instrument noise as well as huge quantities of instrument-generated noise "spikes," and extremely weak variable signal all combined to make the January data uninterpretable.

The second recording episode, June 12-18, 1978, yielded considerably better results. About one day was required to rig up, run a caliper log, and make test records. The water column in the well was below surface level, so no lubricator was required to contain water flow.

Only three surface air guns were operable, but these units functioned well and continued to perform well during most of the survey. The guns were synchronized to an accuracy of $1 \mathrm{~ms}$; the firing delays remained fairly constant throughout the survey. We experienced one short delay due to drift in gun synchronization. During one 4-hr (hour) period, a second gun became inoperable and we had to record with a two-gun source.

On June 15th, a severe thunderstorm and hailstorm interrupted operations for several hours. The hail was baseball-size and caused severe damage to the field vehicles.

Because of soft soil, the guns had a tendency to dig into the earth and they had to be relocated frequently. We finally were required to shovel fill dirt under the firing pans to compensate for this soil compaction prob- 
lem. The units caused a moderate amount of surface damage in the immediate vicinity of the source location.

\section{VERTICAL SEISMIC PROFILE DATA PROCESSING}

Figure V-11 shows the stacked VSP data acquired at Bell Creek oil field, Montana, in January 1978. This is the worst data acquired so far, and we included this section for comparison with the data acquired at the same location in July 1978 (fig. V-12).

Figure V-12 shows the sorted, edited, stacked airgun data at this same location using better field technique and better instruments. This data, when compared with that in figure V-11, clearly shows how field technique can improve the quality of data.

Figure V-13 shows the main steps in the processing of these data. One important difference in the processing of the Bell Creek data is the additional step called shot location shaping filter. If for any reason the source waveform changes during the profiling operation, this change is observed on the source monitor detector and is compensated for in the shot-wavelet correction procedure described in chapter IV. On some occasions at the Bell Creek site, a substantial residual difference in first-arrival waveform was observed after this correction was applied. These differences frequently correlated with small changes in air-gun location, probably because these changes in the source pattern had a slightly different effect on the waveform observed by the monitor detector and likewise the downhole detector. The additional processing step was used to compensate for this difference.

The design philosophy of the shot location shaping filter is identical to that of the monitor phone shaping filter. Let $S^{a}(t)$ be the well-phone response at well location $D$ from source location $A$ and $S^{b}(t)$ be the wellphone response at the same well-phone location $D$ from the source location $B$. Let the output of the well-phone record after monitor-phone shaping filter application be $S^{a}(t)$ and $S^{b}(t)$, respectively. If these two are quite similar, we do not have to apply a shot location shaping filter. But, if a significant difference between these two outputs is detected-either in the waveforms or frequency content-we can design a filter to minimize this difference in the following way.

We design a filter $f(t)$ such that:

$$
S^{b}(t) * f(t)=S^{a}(t)
$$

and we apply this filter $f(t)$ to all records from the source location $B$.
Figure V-10 shows the total wave field. The upgoing waves were multipled five times to balance the amplitude of this section.

In obtaining the transfer function and impedance log shown in figures $\mathrm{V}-14$, the processing steps were identical to those used for USGS Madison No. 1 well except that a three-trace local vertical sum was done at 120 $\mathrm{ft}$ above the top of the Madison Group and a 20-95 $\mathrm{Hz}$ band-pass filter was applied.

\section{IDENTIFICATION OF STRATIGRAPHIC HORIZONS ON THE VERTICAL SEISMIC PROFILE}

In figure $\mathrm{V}-10$, a large number of coherent reflections can be tied to the lithologic log. Two such ties are indicated in the figure: the top of the Madison Group (M) and the Spearfish Formation (Sp). The tie to a surface seismic line, run across the Sam Gary Bell Creek Madison No. 1 well, is indicated at the top of the figure (Miller and others, 1981).

\section{CORONADO COLLINS NO. W-1 WELL}

\section{STRATIGRAPHY, WELL HISTORY, AND AQUIFER PROPERTIES}

The Coronado Collins No. W-1 well is located in $\mathrm{NW}^{1 / 1} / \mathrm{NE}^{1 / 4}$ sec. 33 , T. $45 \mathrm{~N}$., R. $61 \mathrm{~W}$. of Weston County, Wyo. The hole was drilled as a water-supply well for secondary recovery operations in the Newcastle oil field. The well spuds in the Upper Cretaceous Belle Fourche Shale and terminates near the base of the Mississippian Pahasapa Limestone. The total depth is $3,600 \mathrm{ft}$. The hole contains 7 -in. casing to $1,031 \mathrm{ft}$, $41 / 2$-in. casing to $3,200 \mathrm{ft}$, and $61 / 4-\mathrm{in}$. open hole from $3,200 \mathrm{ft}$ to total depth. A generalized lithologic log with labeled formation tops is illustrated in figure $\mathrm{V}-15$.

The Pahasapa Limestone is between 410 and $440 \mathrm{ft}$ thick and is overlain unconformably by the Pennsylvanian-Mississippian lower part of the Minnelusa Formation (fig. V-15). Probably the Pahasapa Limestone at this locality is underlain unconformably by the Deadwood Formation. Two-thirds of the Pahasapa is micritic limestone; the remainder is composed of two 60 -ft-thick zones of vuggy, finely crystalline dolomite.

Water flows from the Pahasapa Limestone at a rate of $290 \mathrm{gal} / \mathrm{min}$ and the pumping yield approaches 800 $\mathrm{gal} / \mathrm{min}$ (Hodson, 1974). The wellhead pressure is 140 psi. Most of the water probably flows from the two 60 -ft-thick intervals of vuggy dolomite. 


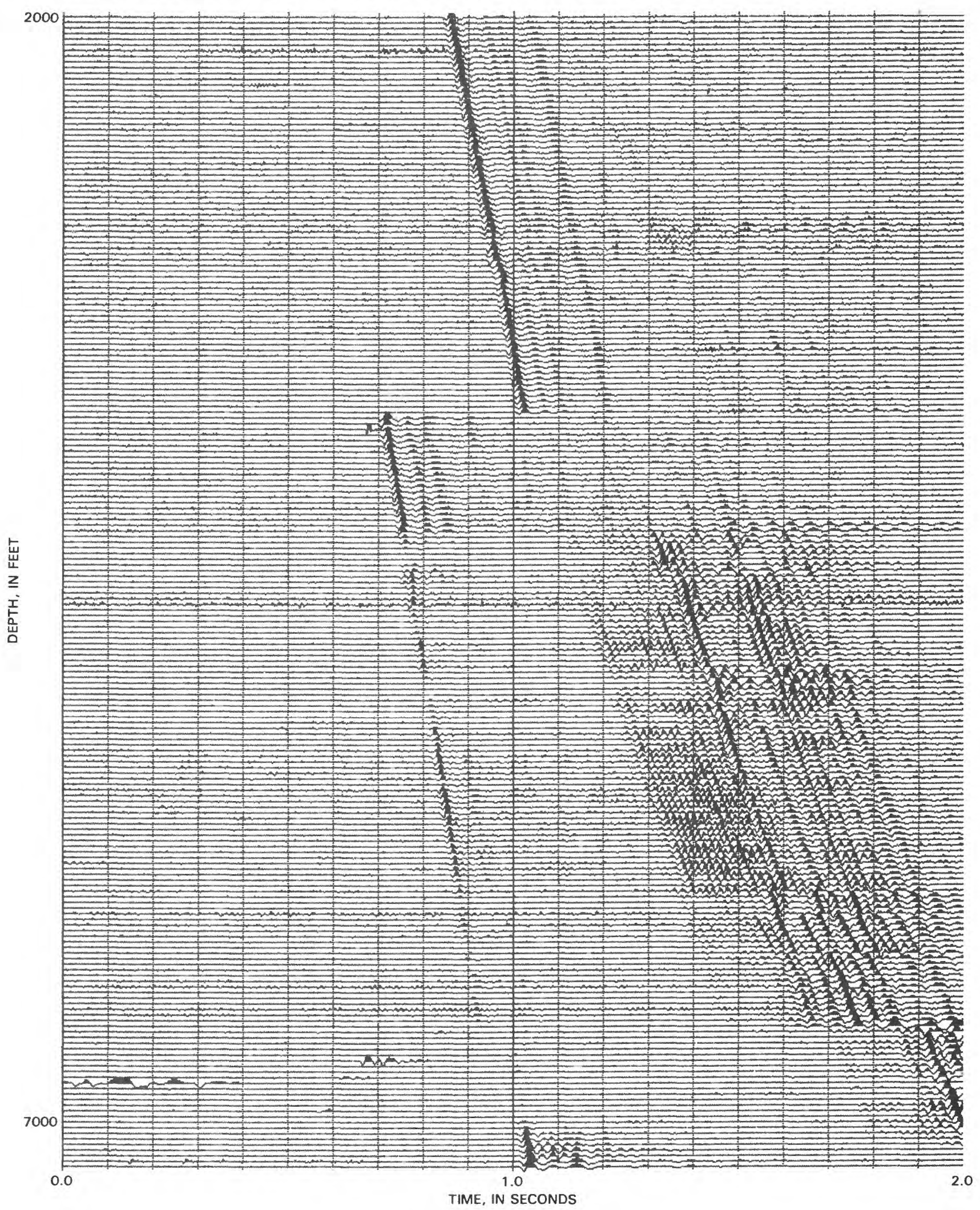

FIGURE V-11._Plot of stacked, edited raw vertical seismic profile data from Sam Gary Bell Creek Madison No. 1 well, Montana, obtained January 23-February 2, 1978. 


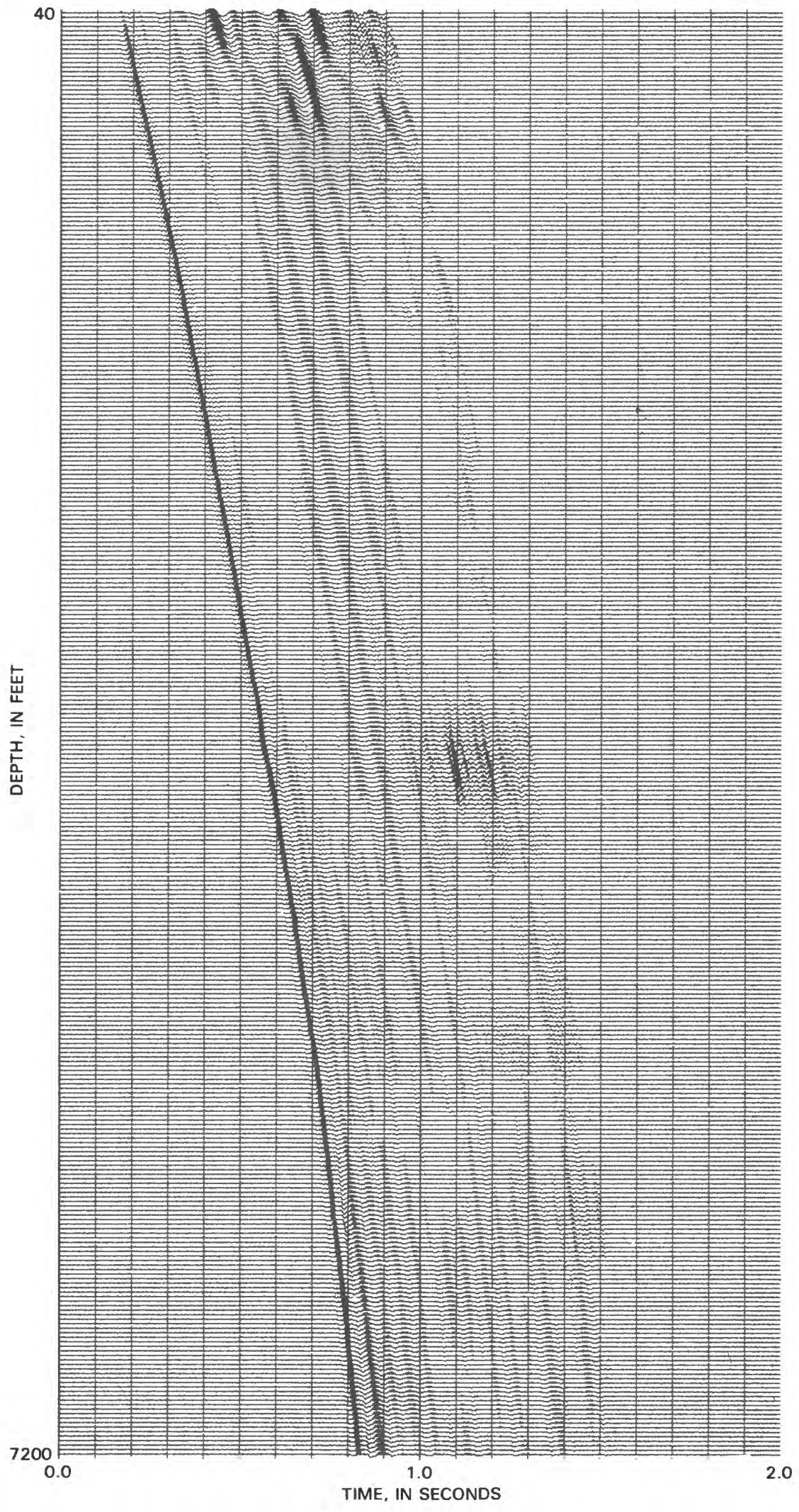

FIGURE V-12.-Plot of stacked, edited raw vertical seismic profile data from Sam Gary Bell Creek Madison No. 1 well, Montana, obtained June 12-19, 1978. 
DEMULTIPLEXING

EDIT, SORT, STACKING

MONITOR PHONE SHAPING FILTER DESIGN AND APPLI CATION

SHOT LOCATION SHAPING FILTER DESIGN AND APPLICATION-At $5400 \mathrm{ft}$ and $6860 \mathrm{ft}$

FREQUENCY ANALYSIS AND BAND-PASS FILTERING - 2/5$80 / 100 \mathrm{~Hz}$

DYNAMIC TIME CORRECTION

MULTICHANNEL VELOCITY FILTERING

DESIGN AND APPLICATION DOWNGOING WAVE TRAIN DECONVOLUTION-Deconvolution operator was designed at $800 \mathrm{ft}$, and band-pass filtering $(8 / 12-80 / 100 \mathrm{~Hz})$ was applied after deconvolution

GAIN APPLICATION $-T^{2}$

CUMULATIVE SUM FOR UPGOING WAVE

MERGE DOWNGOING AND UPGOING WAVES - Downgoing +upgoing $\times 5$

ESTIMATION TRANSFER FUNCTION

INVERSE-Impedance log estimation

Figure V-13.-Processing flow sheet for the Sam Gary Bell Creek Madison No. 1 well, Montana.

\section{VERTICAL SEISMIC PROFILE DATA ACQUISITION}

The vertical seismic profile for the Coronado Collins No. W-1 was acquired June 25-July 1, 1976. Birdwell Division of Seismograph Service Corp. furnished all the equipment and personnel for the survey under contract to the U.S. Geological Survey. Because of the considerable artesian pressure, a lubricator was installed above the wellhead to contain water flow. Three separate profiles were made, with source offsets of $150 \mathrm{ft}, 1 / 2 \mathrm{mi}$, and $1 \mathrm{mi}$. Explosives were used for this survey; they included dynamite, nitramon primers, and water primers.

A fair quality data set was obtained at the $150-\mathrm{ft}$ offset hole, using nitramon primers. Some difficulty was encountered in getting the relatively light charge to a consistent depth of $175 \mathrm{ft}$. Weights were required to get the charge to proper depth and keep them there, which proved to be a time-consuming (and thus expensive) procedure. To expedite the operation, four source holes were used alternately; this caused considerable variation in source waveforms. We also tried alternating among the three offset distances. This alternation gave the shooting crews more time to reload the holes, but we were then plagued with coordination problems among the shooting crews at the three source locations.

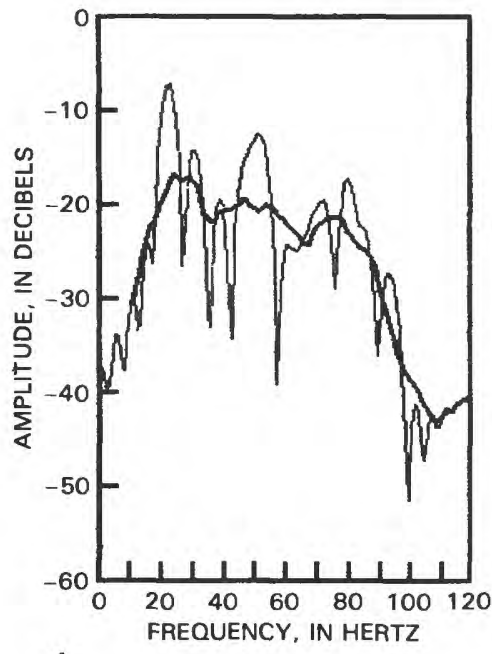

A

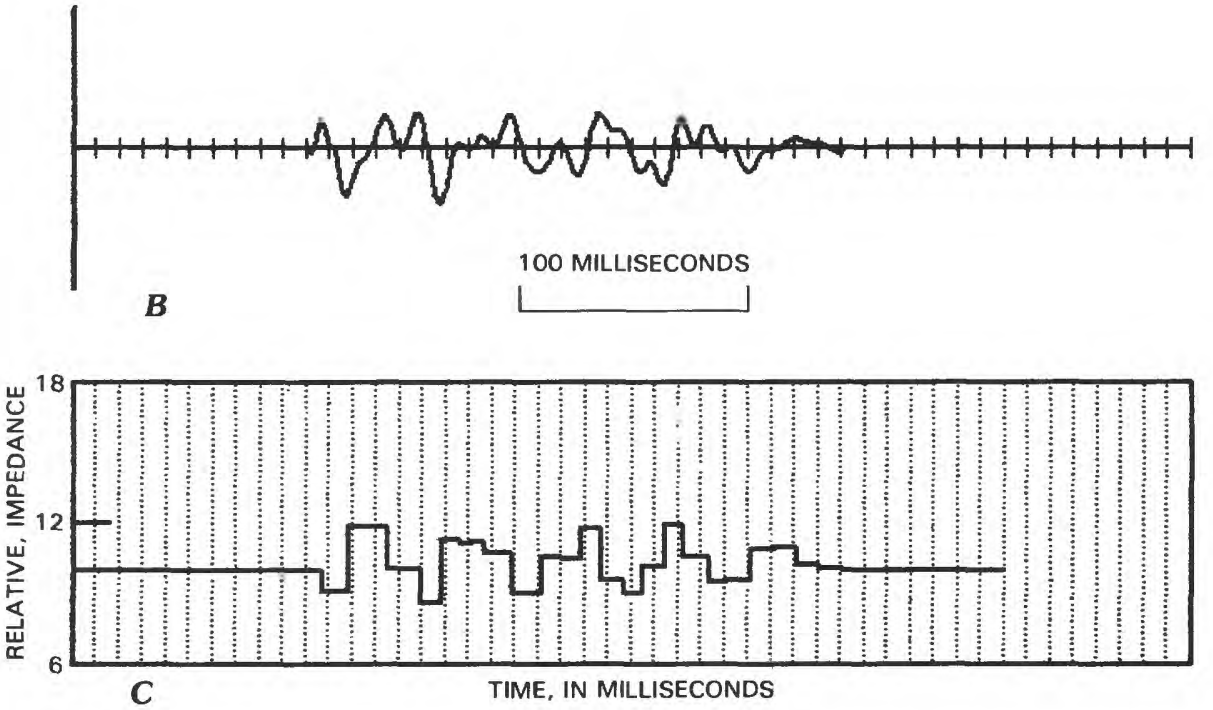

Figure V-14.-Calculation of the transfer functions of the Madison and associated aquifers from vertical seismic profile data at the Sam Gary Bell Creek Madison No. 1 well, Montana. A, Amplitude spectrum of the transfer function; $B$, time-domain transfer function; $C$, estimated acoustic impedance log. 


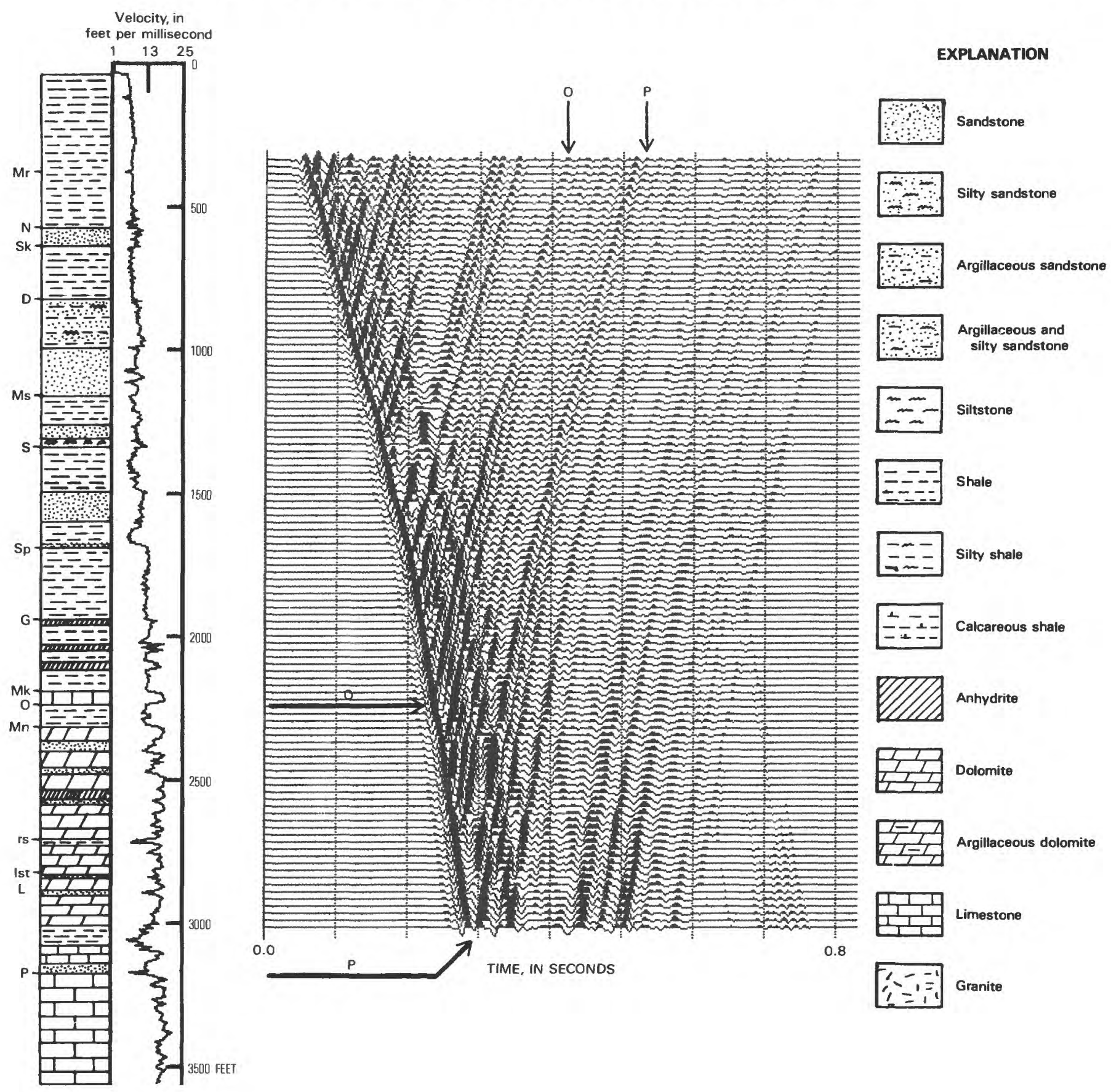

Figure V-15.-Lithologic and velocity logs of Coronado Collins No. W-1 well, Wyoming, tied to the total seismic wave field from vertical seismic profile. Mr, Mowry Shale; N, Newcastle Sandstone; Sk, Skull Creek Shale; I, Inyan Kara Group; Ms, Morrison Formation; S, Sundance Formation; Sp, Spearfish Formation; G, Goose Egg Formation; Mk, Minnekahta Limestone; O, Opeche Shale; Mn, Minnelusa Formation; rs, red shale marker of Minnelusa Formation; 1st L, First Leo sandstone (oil industry usage) of Minnelusa Formation; $\mathrm{P}$, Pahasapa Limestone. Velocity is in feet per millisecond ( $\mathrm{ft} / \mathrm{ms})$. 


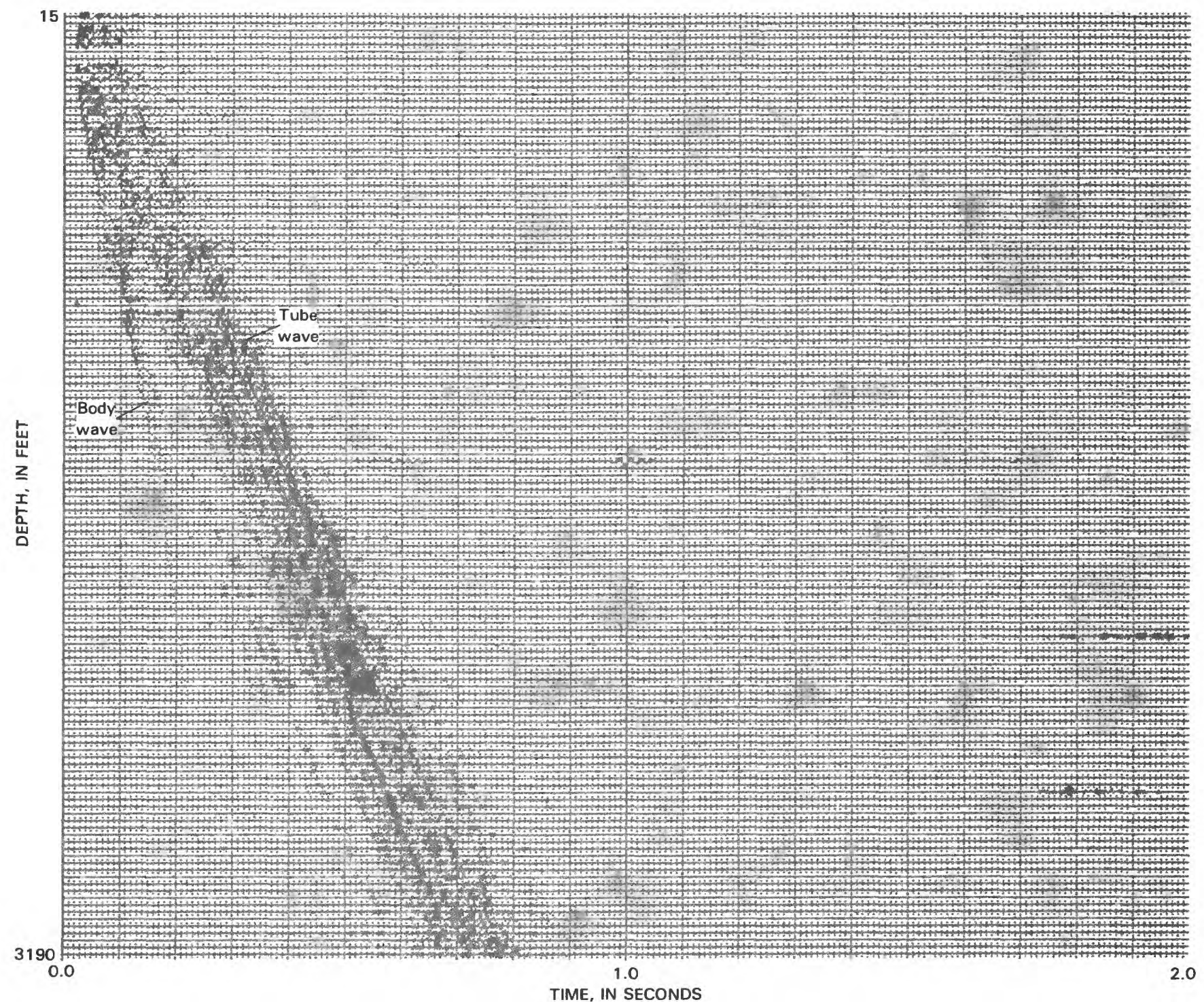

FigurE V-16.-Edited, static-corrected raw vertical seismic profile data from the Coronado Collins No. W-1 well, Wyoming.

Comparatively large explosive charges were required at the longer offset holes. The charges ranged from 10$25 \mathrm{lb}$. With these larger charges we were plagued with hole fatigue. The source waveforms varied drastically from shot to shot. Hole blow frequently was severe, and the shooting crews soon were wading around in a quagmire of mud. The water tamp varied considerably from shot to shot. Retamping the holes expeditiously was difficult, and on several occasions the holes were shot with an inadequate water column. As a result of all these factors, the data quality from the long offset sources were extremely poor and no quantitative analysis of these data has been attempted. All subsequent material discussed in this report about the Coronado Collins No. W-1 well relates to the near offset VSP unless the contrary is stated specifically.
Severe tube-wave noise corrupted the near offset data. Considerable ghosting was present. Substantial source signature changes (due to changing shotholes), varying the source depth, and hole fatigue are apparent. These problems could have been mitigated by using a greater offset distance, placing the source at the base of the low-velocity layer, and proceeding with the operation much more slowly. The latter would have precluded any attempt to acquire long offset data.

An uphole survey was run in a near-offset hole, and upholetimes were obtained at 10 -ft intervals from total depth to the surface. These data, combined with good data from a buried signature detector, enabled us to compensate for many of the defects in the near-offset data. A reasonably good interpretation was obtained eventually. 


\section{VERTICAL SEISMIC PROFILE DATA PROCESSING}

Figure V-16 shows the original sorted, time-breakcorrected, well-phone data from explosive source with a spatial sampling interval of $25 \mathrm{ft}$.

Because the shooting medium is good in this areaalmost homogeneous shale-the small explosive charges $(1 / 4-1 \mathrm{lb})$ were adequate for the near-offset source. This VSP is the only profile in which explosives were used that we processed intensively and included in this report. A processing flow sheet is shown in figure V-17.

The data displayed in this section will show that the excellent source monitor information enabled us to do a good job of compensating for variations in source waveform. A spot time correction, a "static," was necessary for nearly every shot because the shot depth varied from $90-200 \mathrm{ft}$. The tube wave noise in the Collins data is probably the worst we have ever experienced (fig. V-16). The data in figure V-16 are plotted with constant gain. The amplitude of the tube waves relative to the first arrival body waves is so great that the latter are almost totally obscured. Before we could perform any meaningful computer manipulation of these data, we had to apply a time-varying amplitude adjustment to keep the average amplitude approximately constant. This process is called digital automatic gain control or digital AGC. However, digital AGC was

\section{DEMULTIPLEXING}

EDIT, SORT, TIME BREAK CORRECTION

UPHOLE PHONE SHAPING FILTER DESIGN AND APPLICATION SHOT STATIC CORRECTION

FREQUENCY ANALYSIS AND BAND-PASS FILTERING-
$5 / 10-85 / 100 \mathrm{~Hz}$
GAIN APPLICATION-Digital automatic gain control (digital
AGC)
MULTICHANNEL VELOCITY FILTERING
DESIGN AND APPLICATION DOWNGOING WAVE TRAIN
DECONVOLUTION-Deconvolution operator was designed
at $1040 \mathrm{ft}$, and band-pass filtering $(15 / 20-80 / 100 \mathrm{~Hz})$ was
applied after deconvolution
CUMULATIVE SUM FOR UPGOING AND DOWNGOING
WAVES
MERGE DOWNGOING AND UPGOING WAVES-Downgoing
+ UPGoing
ESTIMATION TRANSFER FUNCTION

ESTIMATION TRANSFER FUNCTION

INVERSE-Impedance log estimation

Figure V-17.-Processing flow sheet for the vertical seismic profile data from the Coronado Collins No. W-1 well, Wyoming. not applied in the calculation of the Madison transfer function. The total wave field is shown in figure $\mathrm{V}-15$.

In estimating the transfer function for the Madison aquifer, we followed the same procedure as with the USGS Madison No. 1 well, except that local vertical summing was done at $150 \mathrm{ft}$ above the top of the Pahasapa Limestone. The result of the transfer function calculation is shown in figure $\mathrm{V}-18$.

\section{IDENTIFICATION OF THE STRATIGRAPHIC HORIZONS ON THE VERTICAL SEISMIC PROFILE}

In figure V-15 we observe a large number of major coherent upward-traveling events that can be tied to the lithologic log. The ties to the Opeche Shale $(0)$ and the Pahasapa Limestone $(\mathrm{P})$ are indicated in the figure.

\section{BECHTEL ETSI NO. 0-1 WELL}

\section{STRATIGRAPHY, WELL HISTORY, AND AQUIFER PROPERTIES}

The Bechtel ETSI No. $0-1$ is located in NW1/4NE1/4 sec. 28, T. 36 N., R. 62 W. of Niobrara County, Wyo. The hole was drilled as a possible water-supply well for a future Gillette, Wyo., to Little Rock, Ark., coalslurry pipeline. The well spuds in the Tertiary Arikaree and White River Formations and terminates in Precambrian crystalline rocks. The total depth is $3,269 \mathrm{ft}$. The well contains $87 / 8$-in. casing to $117 \mathrm{ft}, 4 \frac{1}{2}$-in. casing to $2,922 \mathrm{ft}$, and $6 \frac{1}{4}$-in. open hole from $2,920 \mathrm{ft}$ to total depth. The cement bond log indicated that the casing is not bonded to the borehole above $800 \mathrm{ft}$. A generalized lithologic $\log$, with formation tops identified, is shown on figure V-19.

The Pahasapa Limestone is about $270 \mathrm{ft}$ thick and is bounded unconformably by the Cambrian Deadwood Formation at the base and the Pennsylvanian-Mississippian lower part of the Minnelusa Formation at the top (fig. V-19). Micritic limestone dominates the upper one-half of the Pahasapa, whereas partly vuggy, crystalline dolomite characterizes the bottom half of the unit.

The water level in the Bechtel ETSI No. 0-1 fluctuates between 300 and $400 \mathrm{ft}$ below ground level. On April 24-29, 1974, water was pumped at a rate of 57 $\mathrm{gal} / \mathrm{min}$ from the Pahasapa-Deadwood interval with a drawdown of $88 \mathrm{ft}$ (Anderson and Kelly, 1976). Prior to pumping, the well was acidized and swabbed. We speculate that most of this water originated from the vuggy dolomite units in the lower half of the Pahasapa 


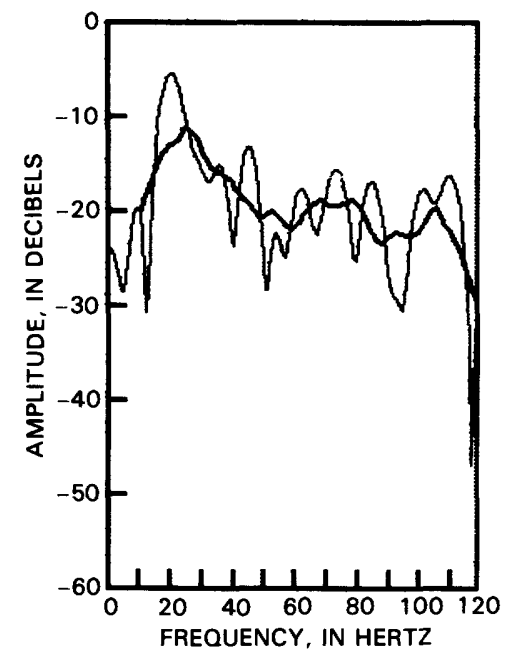

A
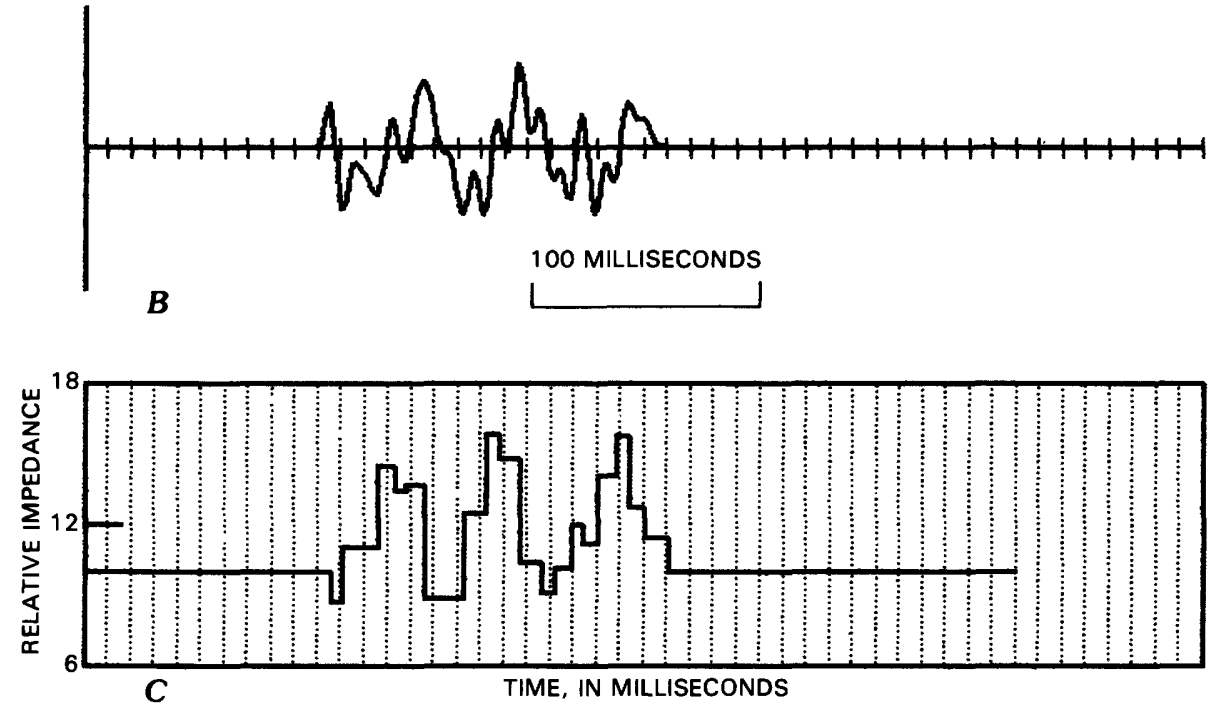

Figure V-18.-Calculation of the transfer functions of the Madison aquifer from vertical seismic profile data at Coronado Collins No. W-1 well, Wyoming. $A$, Amplitude spectra of the transfer function; $B$, time-domain transfer function; $C$, estimated acoustic impedance $\log$.

Limestone. This low-productivity well and the USGS Madison No. 2 are considered for the purposes of this investigation to be unproductive.

\section{VERTICAL SEISMIC PROFILE DATA ACQUISITION}

The Bechtel ETSI 0-1 well was profiled three times: in March 1975, July 1976, and August 1978. All three profiles were made under contract to the Birdwell Division, Seismograph Services Corp.

One-pound explosive charges were used in March 1975. Six shot holes were arranged in a six-arm star pattern, $150 \mathrm{ft}$ from the well. Detector spacing in the well was $100 \mathrm{ft}$. The coarse spacing and highly variable source waveforms precluded any extensive processing of these data.

The profile was repeated in July 1976 using a 25 - $\mathrm{ft}$ detector spacing. Nitramon primers and $1 / 4-\mathrm{lb}$ water primers were used for the source. The source environment was kept as uniform as possible. Additional profiling was performed with a source offset of $1 / 2 \mathrm{mi}$ and $1 \mathrm{mi}$. Larger sources $(5-20 \mathrm{lb})$ were required at the longer offset locations. For the long offsets, we encountered the same problems here that were described for the Coronado Collins No. W-1 well. No meaningful interpretation of these data has been possible as yet. Considerable variability in source waveform and excessive tube noise made processing and interpretation of the near-offset data difficult, and we decided to reprofile the well.

Three synchcronized surface air guns at a mean distance of $500 \mathrm{ft}$ were used on the August 1978 survey. The detector spacing was reduced to $20 \mathrm{ft}$. Although the air-gun signature frequencies were substantially lower than those obtained with explosives, the quite significant increases in source signature consistency proved to be well worth the price paid in loss of high frequencies. Extensive computer processing has been possible, and a satisfactory tie to the subsequently obtained surface profile data has been made.

\section{VERTICAL SEISMIC PROFILE DATA PROCESSING}

The original, surted, raw data from the March 1975 profile is displayed in figure V-20. Note the rapid, 


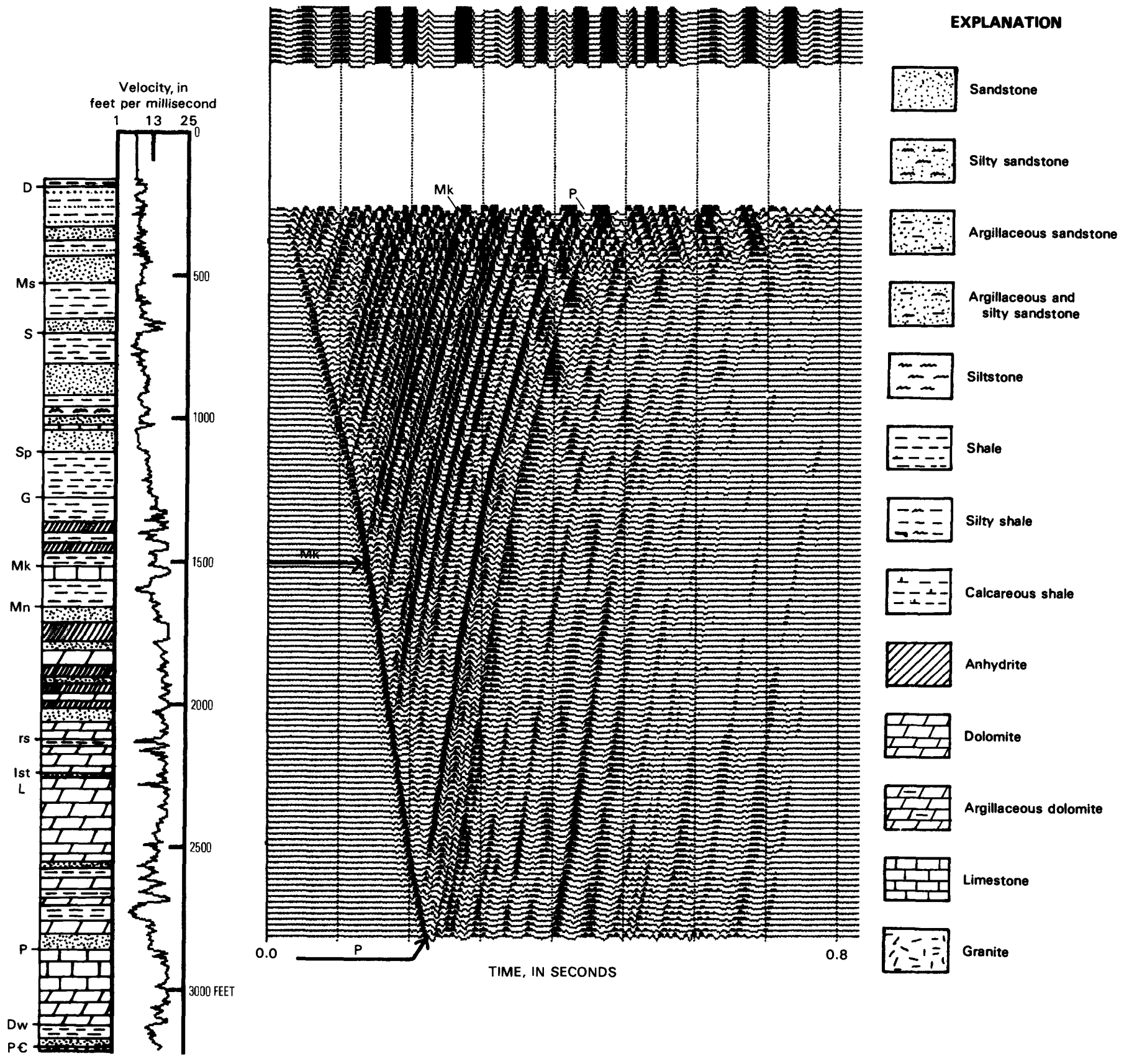

FIGURE V-19.-Lithologic and velocity logs of Bechtel ETSI No. 0-1 well, Wyoming, tied to the total seismic wave field from the vertical seismic profile and the surface seismic profile across well (top of figure). Ms, Morrison Formation; S, Sundance Formation; Sp, Spearfish Formation; G, Goose Egg Formation; Mk, Minnekahta Limestone; Mn, Minnelusa Formation; rs, red shale marker of Minnelusa Formation; 1st L, First Leo sandstone (oil industry usage) of Minnelusa Formation; P, Pahasapa Limestone; Dw, Deadwood Formation; Pc, Precambrian rocks. Velocity is in feet per millisecond $(\mathrm{ft} / \mathrm{ms})$. 


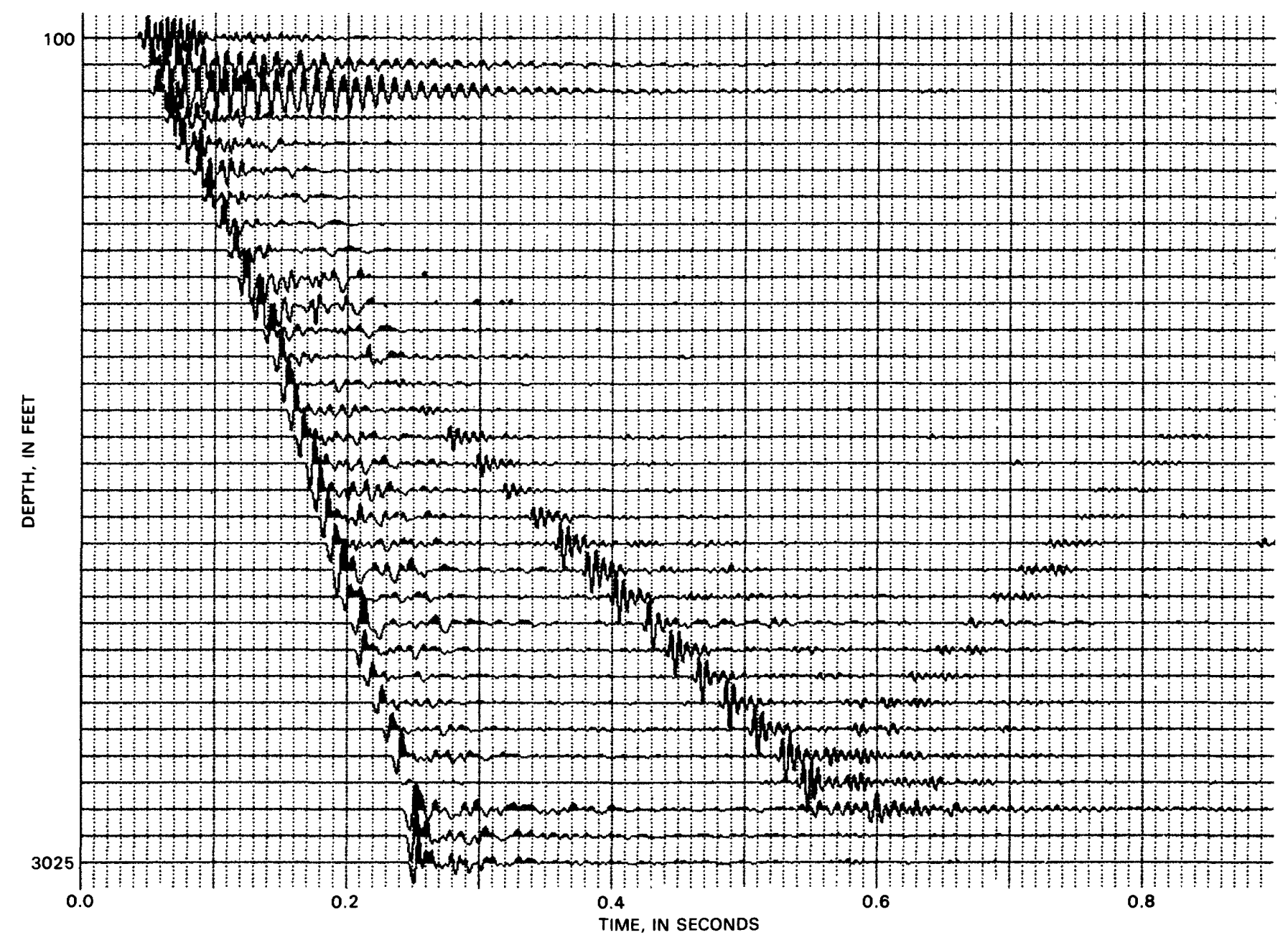

FIGURE V-20.--Sorted raw vertical seismic profile data obtained March 1975 from the Bechtel ETSI No. 0-1 well, Wyoming.

drastic changes in first arrival waveform with depth. This change in the waveform of the first arrival is due almost entirely to source waveform changes. Uphole and time-break detector data were obtained on this operation, but the uphole recordings were of poor quality. The uphole arrival times were erratic, which suggests that the shot depths may be in error. Strong tube waves are present also. Some of the tube-wave modes appear to have an anomalously low speed, which probably are the result of borehole fluid waves that have been reflected at least once by the well detector itself. This phenomenon is described by Hardage (1981). Velocity filtering to separate upgoing and downgoing waves was not successful. The spatial sampling was too coarse and the source waveform too inconsistent.
The raw, near offset data obtained in July 1976 are shown in figure V-21. The principal difference between these data and those of figure V-20 is the spatial sampling. Some rudimentary processing was attempted on these data. The effect of band-pass filtering is shown in figure V-22. The top four traces are band-pass filtered $(2 / 4-80 / 95 \mathrm{~Hz})$ versions of the bottom four. We note that the filter was successful in reducing the tubewave amplitude, relative to the first arrival body wave. No improvement in data consistency was obtained by attempting to shape the source waveform. Our lack of success on this well in using the surface detector as a monitor of the source waveform is the main reason that we used deeply buried detectors for a source monitor in all subsequent profiling operations. 


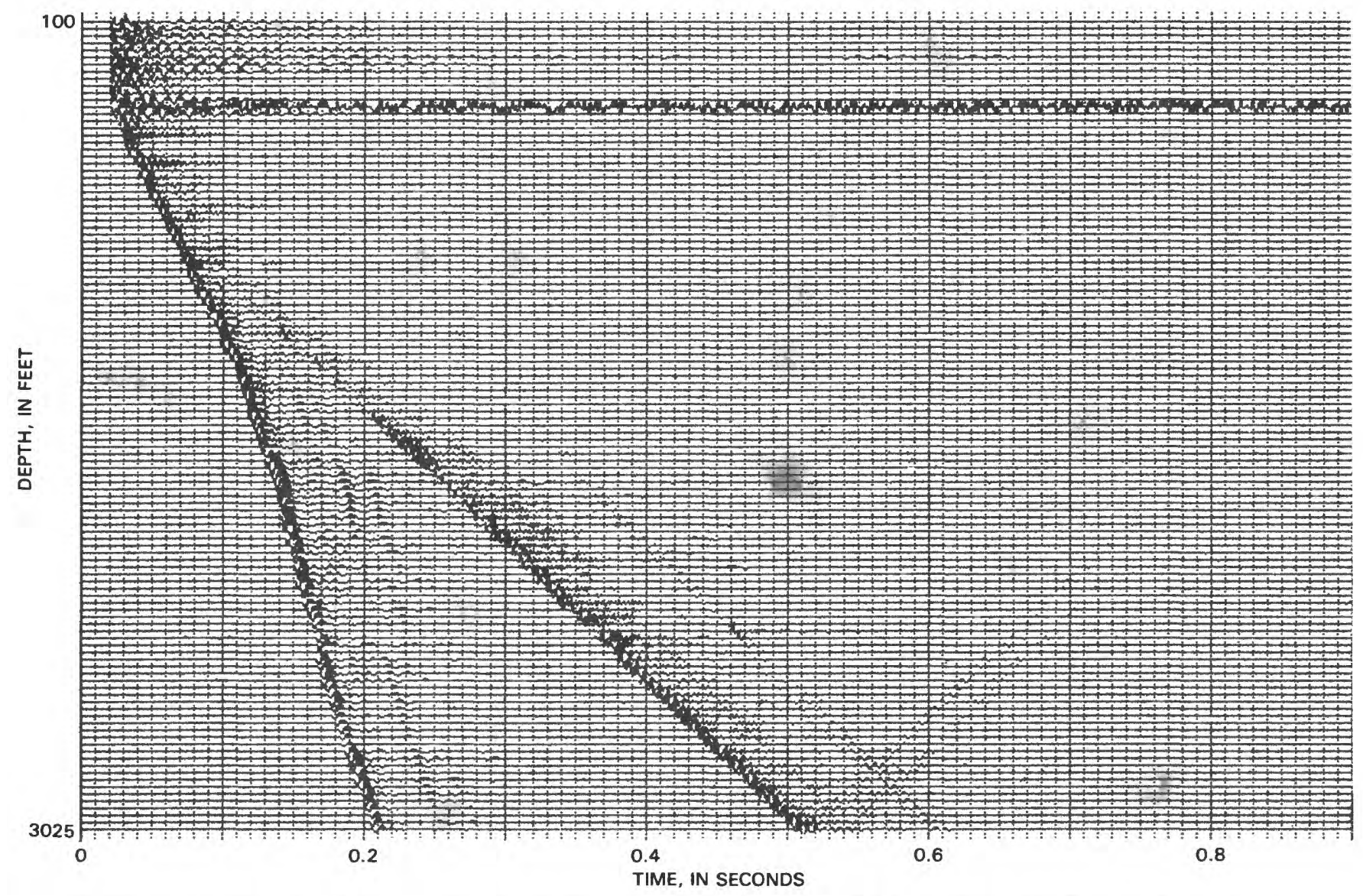

Figure V-21.-Sorted raw vertical seismic profile data obtained July 1976 from the Bechtel ETSI No. 0-1 well, Wyoming.

The edited, sorted, and stacked surface air-gun recordings are shown in figure V-23. The source waveform consistency is excellent. A buried source monitor recording was made, which enabled us to do an effective job of source waveform compression. The monitor data also corroborated the consistency of the source waveform. Extensive processing of these data was possible. Figure V-24 shows a processing flow sheet for these data.

After comparing figures V-20, V-21, and V-22, we conclude:

1. The air-gun data are lower in frequency than are the data obtained using explosives.

2. The air-gun data have reduced tube noise greatly.

3. The first arrival waveforms change quite slowly when air guns are used. The reduction in tube wave noise probably is due to the low frequencies involved and to greater offset distance. The combined wave field, with a five-fold amplitude boost in the upgoing wave field, is shown in figure V-19.

A reflection transfer function was estimated for the Madison aquifer (fig. V-25). Three-level stacks were created from the upgoing and downgoing wave fields, at a point $120 \mathrm{ft}$ above the Madison. The Kalman filter technique was used to generate the time-domain transfer function after the stacked data were filtered, to confine the data to a frequency range of $16-110 \mathrm{~Hz}$. The acoustic impedance log was then calculated from this transfer function.

\section{IDENTIFICATION OF STRATIGRAPHIC HORIZONS ON THE VERTICAL SEISMIC PROFILE}

A multiplicity of upward-traveling coherent seismic events is shown in figure V-19. These events can be tied directly to the lithologic log shown at the right of the figure. The ties to the Minnekahta Limestone 


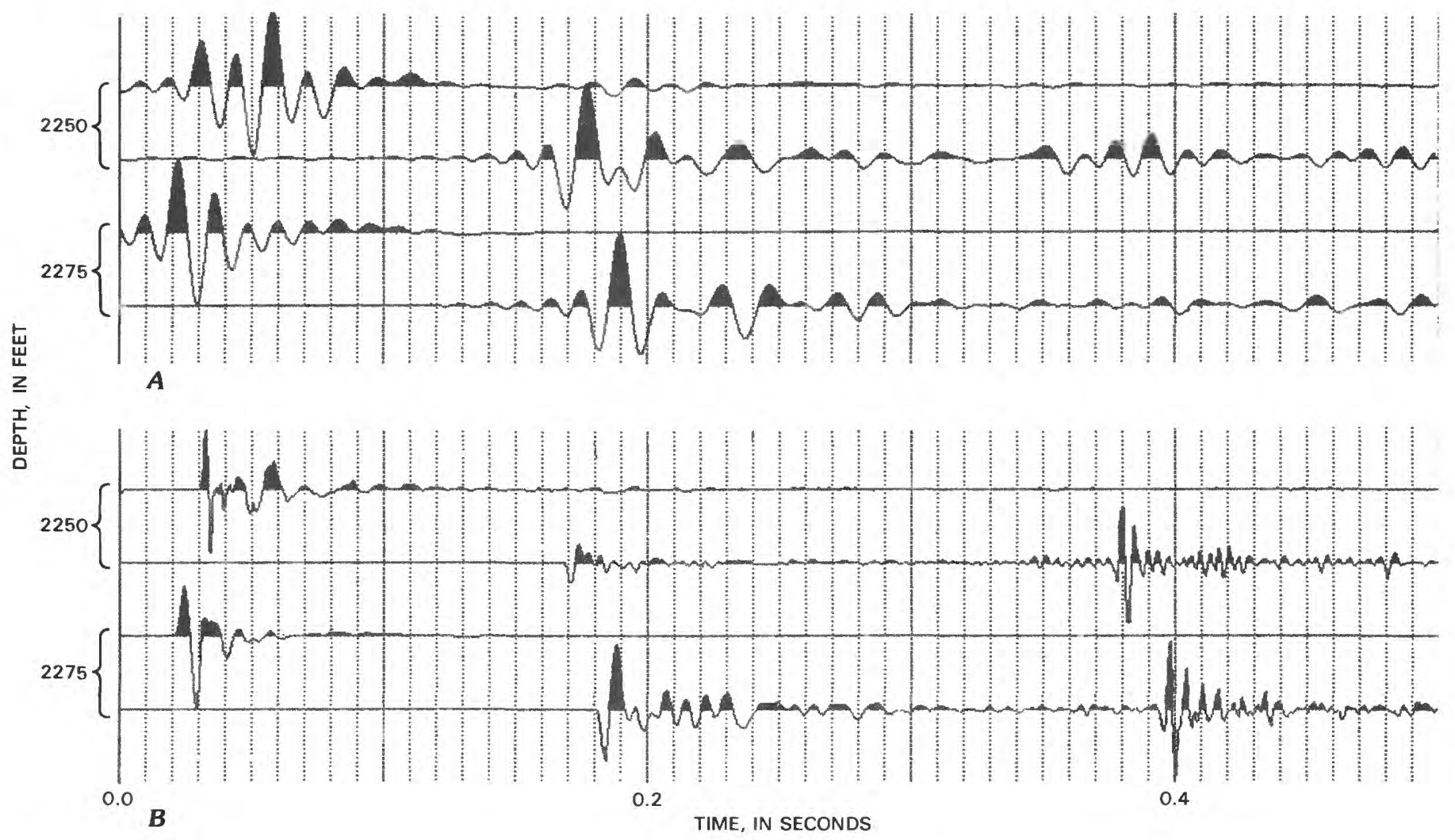

FIGURE V-22.-Downhole and surface recordings from 2,275 ft and 2,250 ft, Bechtel ETSI No. 0-1 well, Wyoming. Vertical seismic profile of July 1976. $A$, Raw data; $B, 4-80 \mathrm{~Hz}$ digitally filtered.

(Mk) and the Pahasapa Limestone (P) are indicated on the figure. These events also are tied to a surface profile run across the well at the top of figure V-19 (Lee and others, 1981).

\section{PFISTER FEE NO. 1 WELL, RED BIRD OIL FIELD \\ STRATIGRAPHY, WELL HISTORY, AND AQUIFER PROPERTIES}

The Pfister Fee No. 1, also called the Mule Creek Oil Company Fee No. $1-4325$, is located in NE1/4 $\mathrm{SE}^{1 / 4}$ sec. 25 , T. 38 N., R. 62 W. of Niobrara County, Wyo. This well produces oil from the Leo sandstone, an economic unit in the middle part of the Minnelusa Formation. The well spuds in the Upper Cretaceous Carlile Shale and ends about $340 \mathrm{ft}$ into the lower part of the Minnelusa Formation of Pennsylvanian-Mississippian age. The total depth is $3,780 \mathrm{ft}$. The well is cased with 103/4-in. pipe to $199 \mathrm{ft}$ and 71/2-in. pipe from $199 \mathrm{ft}$ to total depth. A velocity log suggests that the casing is poorly bonded to the borehole wall above $2,200 \mathrm{ft}$. Oil is produced from the Leo sandstone at $3,171 \mathrm{ft}$ at a rate of $10 \mathrm{bbl} / \mathrm{d}$ (barrels per day). When the pumping is stopped, the oil rises to a depth of $650 \mathrm{ft}$ in the well bore. A generalized lithologic log with labeled formation tops was projected from the nearby Mule Creek Oil Company Raben No. 1-3425 in SW1/4 $\mathrm{SE}^{1 / 4}$ sec. 25, T. 38 N., R. 62 W. (fig. V-26).

The Pahasapa Limestone was not found in this well, but its top is estimated to be about $90 \mathrm{ft}$ below the total depth of the well. The thickness of the Pahasapa Limestone probably ranges between 270 and $290 \mathrm{ft}$.

\section{VERTICAL SEISMIC PROFILE DATA ACQUISITION}

The Pfister Fee No. 1 was profiled twice. First we used a downhole air-gun array, and then we used a single land air gun. The field work was conducted July 26-August 1, 1977.

The Pfister Fee No. 1 is a producing oil well. The well had to be pulled prior to performing the survey. The pull involved partial disassembly of the surface pumping equipment and wellhead, removal of all sucker rod, tubing, and packers. The crude is sour, and corro- 


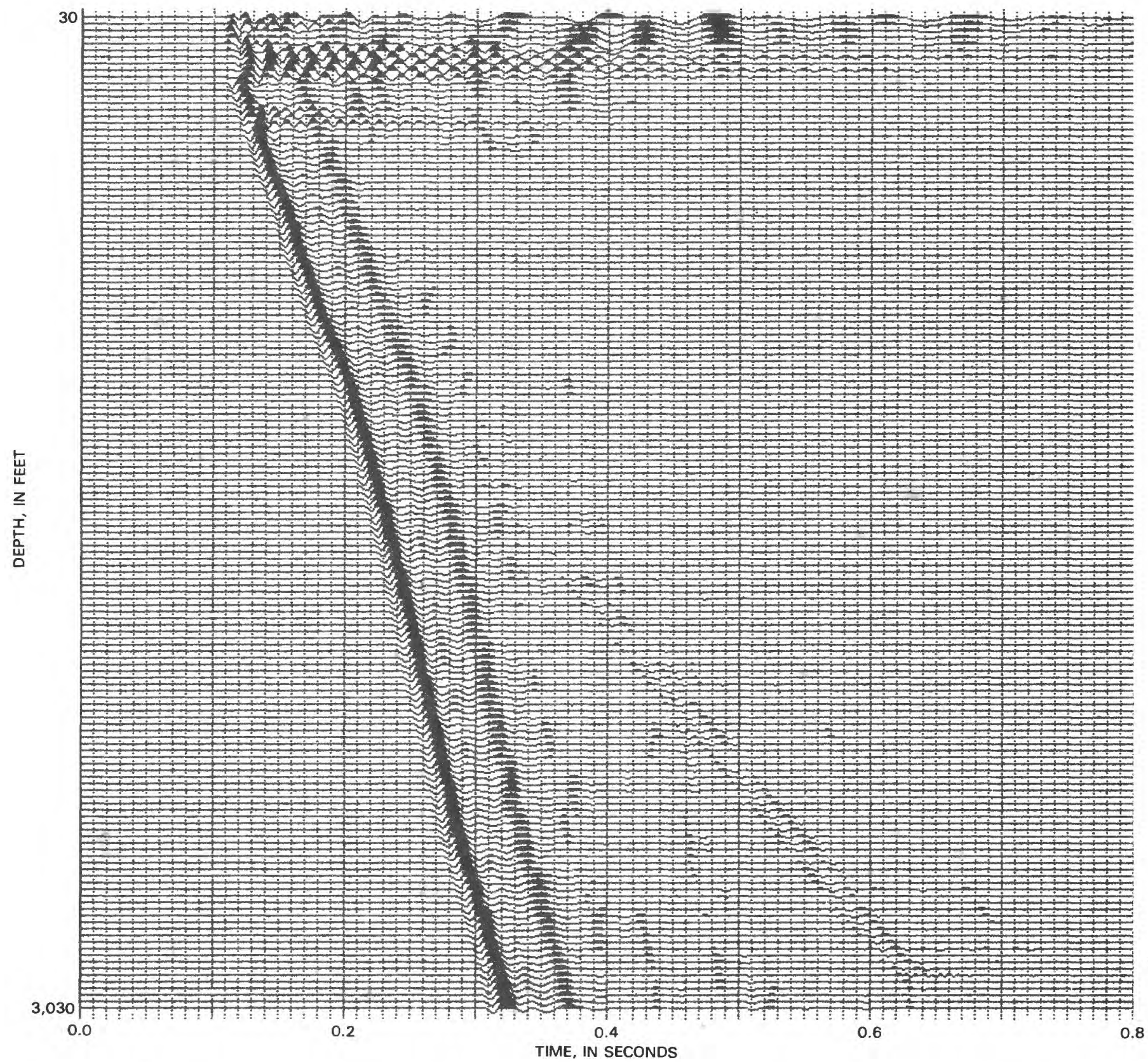

Figure V-23.-Sorted, edited, and stacked raw data from the Bechtel ETSI No. 0-1 well, Wyoming. Air-gun vertical seismic profile of August 1978 .

sion of some of the downhole hardware made this operation difficult and added considerably to the expense of the survey.

In the downhole air-gun profile, four Bolt 5,500 ten cubic-inch air guns were placed in source holes spaced $15 \mathrm{ft}$ apart at a mean distance of $200 \mathrm{ft}$ from the well. Source depth was in excess of $100 \mathrm{ft}$. The guns were charged, through a pressure reducer, to about 1,800 psi with nitrogen bottles.
The downhole air gun experiment was plagued throughout with technical-mechanical problems. The individual guns proved nearly impossible to synchronize. Time-break hydrophones were located near the guns to monitor firing time. However, either due to individual differences in the hydrophones or the guns or the source environment, or some combination of these, the recorded time-break waveforms varied considerably. This variation made a choice of zero time subjec- 


\section{DEMULTIPLEXING \\ EDIT, SORT, STACKING \\ FREQUENCY ANALYSIS AND BAND-PASS FILTERING- 6/12-100/125 Hz}

MONITOR PHONE SHAPING FILTER DESIGN AND APPLICATION

DYNAMIC TIME CORRECTION

MULTICHANNEL VELOCITY FILTERING

DESIGN AND APPLICATION DOWNGOING WAVE TRAIN DECONVOLUTION-Deconvolution operator was designed at $500 \mathrm{ft}$, and band-pass filtering $(6 / 12-100 / 125 \mathrm{~Hz})$ was applied after deconvolution

GAIN APPLICATION $-\mathrm{T}^{2}$

CUMULATIVE SUM FOR UPGOING WAVE

MERGE DOWNGOING AND UPGOING WAVES-Downgoing tupgoing $\times 4$

ESTIMATION TRANSFER FUNCTION

INVERSE-Impedance log estimation

Figure V-24.-Processing flow sheet for the Bechtel ETSI No. 0-1 well, Wyoming. Vertical seismic profile data obtained August 1978. tive. The time delay was difficult to control, once one was decided upon, due to frequent malfunction of the time delay controller. The air guns themselves jammed frequently, and then they had to be retrieved from the holes for repairs. The recovery operation was laborious and time consuming. The guns frequently stuck in the source holes and had to be fired repeatedly to break them loose. The holes were cased with plastic pipe. The pipe was ruptured easily if the guns were fired inside the pipe. If fired below the pipe, recovery was especially difficult because the guns frequently "hung up" at the bottom of the casing. Adequate presssure on the guns could not always be maintained. The standard 2,500 psi nitrogen bottles soon dropped below $1,800 \mathrm{psi}$, and they had to be replaced with fresh bottles before more than 10 percent or so of their contents had been used.

Six days were required to profile about $3,000 \mathrm{ft}$. Data quality was poor.

The surface air-gun performance was good by comparison. The gun failed once, which caused a delay in order to repair a broken diaphragm. Several heavy studs holding the diaphragm retainer broke causing excessive water leakage, but the water level was maintained easily by frequent refilling until the profile was completed. The studs were replaced between the Pfister Fee No. 1 and the USGS Madison No. 2 operation.

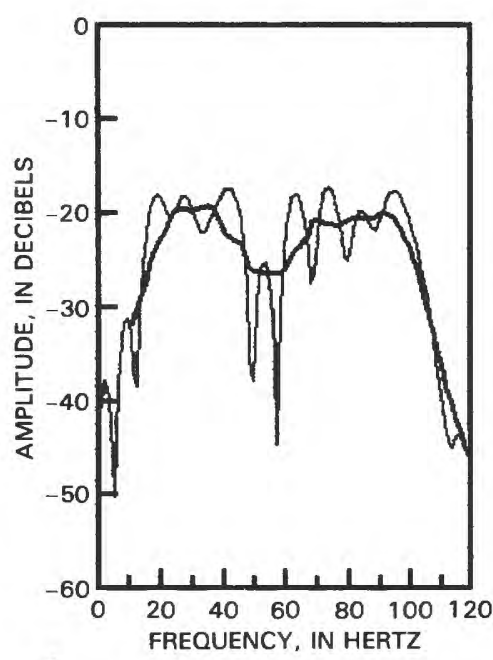

A
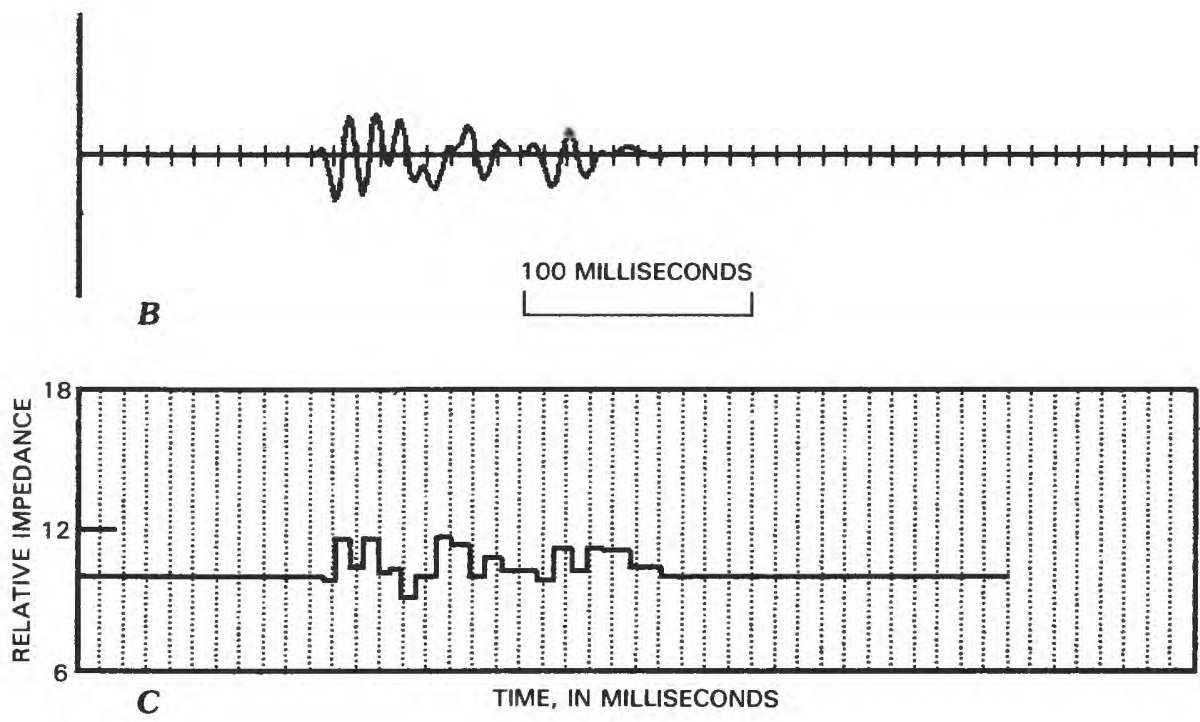

FIGURE V-25. - Calculation of the transfer functions of the Madison aquifer from vertical seismic profile data at the Bechtel ETSI No. 0-1 well, Wyoming. $A$, Amplitude spectrum; $B$, time-domain transfer function; $C$, estimated acoustic impedance log. 
Velocity, in

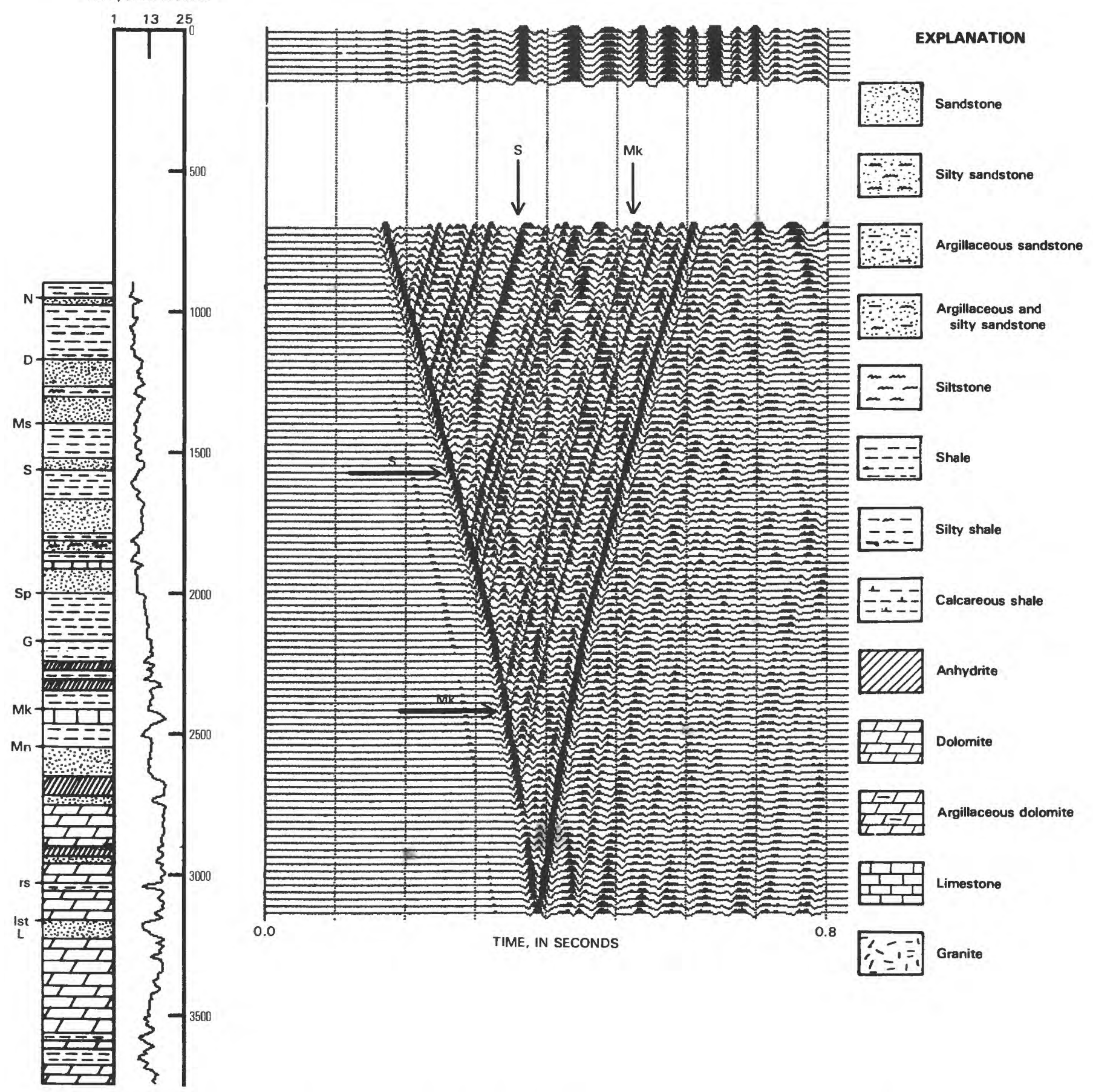

Figure V-26.--Lithologic and velocity logs of Pfister Fee No. 1 well, Wyoming, tied to the total seismic wave field from the vertical seismic profile and the surface seismic profile across well (top of figure). N, Newcastle Sandstone; I, Inyan Kara Group; Ms, Morrison Formation; S, Sundance Formation; Sp, Spearfish Formation; G, Goose Egg Formation; Mk, Minnekahta Limestone; Mn, Minnelusa Formation; 1st L, First Leo sandstone (oil industry usage) of Minnelusa Formation. Velocity is in feet per millisecond (ft/ms). 


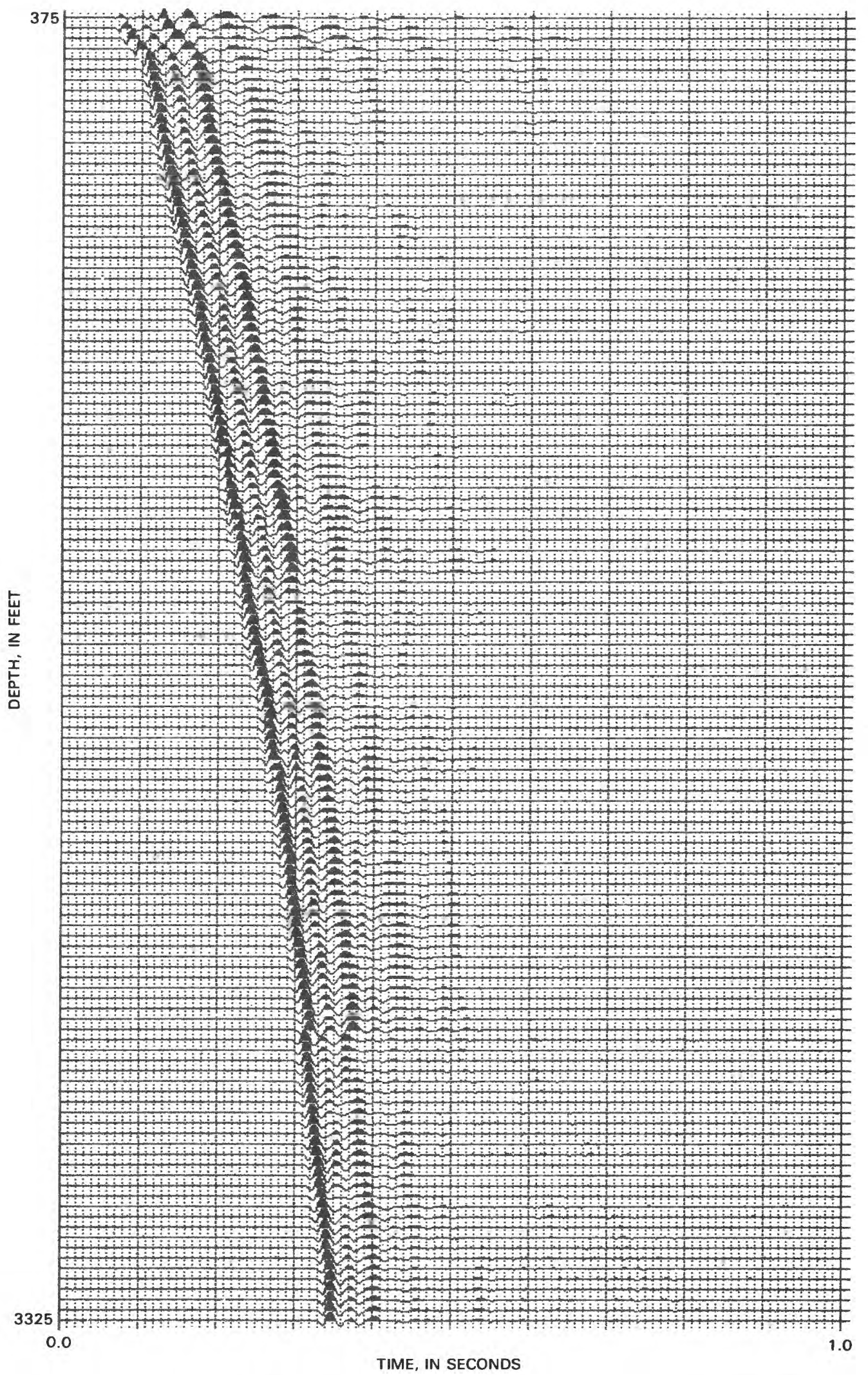

Figure V-27. - Stacked, sorted, raw vertical seismic profile data from the Pfister Fee No. 1 well, Wyoming. 
DEMULTIPLEXING

EDIT, SORT, TIME BREAK CORRECTION, STACKING

FREQUENCY ANALYSIS AND BAND-PASS FILTERING4/8-125/150 Hz

MONITOR PHONE SHAPING FILTER DESIGN AND APPLICATION

MULTICHANNEL VELOCITY FILTERING

DESIGN AND APPLICATION DOWNGOING WAVE TRAIN DECONVOLUTINN-Deconvolution operator was designed at $630 \mathrm{ft}$, and band-pass filtering $(8 / 14-96 / 125 \mathrm{~Hz})$ was applied after deconvolution

GAIN APPLICATION $-T^{2}$

CUMULATIVE SUM FOR UPGOING WAVE

MERGE DOWNGOING AND UPGOING WAVES-Downgoing +upgoing $\times 4$

ESTIMATION TRANSFER FUNCTION

INVERSE-Impedance log estimation

Figure V-28.-Processing flow sheet for the Pfister Fee No. 1 well, Wyoming.

The surface air gun had a tendency to dig itself into the ground after repeated firing at one location. For this reason, it was moved occasionally and this moving caused some problems in processing because the source waveform changed slightly after each relocation. The problem was mitigated by firing the gun 10-20 times after relocating and before recording to compact the soil beneath the gun. Significantly, the surface air gun produced vastly superior data at this well in one-fifth the time.

\section{VERTICAL SEISMIC PROFILE DATA PROCESSING}

Figure V-27 shows the stacked well-phone data produced by the single surface air-gun source with a spatial sampling interval of $25 \mathrm{ft}$.

The data processing flow sheet is shown in figure $\mathrm{V}-28$.

A time-break correction was made before stacking for these data because there was about 4-ms time-break variation at a given level.

The total wave field is shown in figure $\mathrm{V}-26$; upgoing waves are multiplied four times to balance the overall amplitude of this section.

The transfer function computation and calculated impedance $\log$ are shown in figure V-29.

\section{IDENTIFICATION OF STRATIGRAPHIC HORIZONS ON THE VERTICAL SEISMIC PROFILE}

A multiplicity of upward-traveling coherent seismic events can be tied to the lithologic log directly from figure V-26. Two such ties are indicated in the figure: the Sundance Formation (S) and the Minnekahta Limestone (Mk). These two events also are tied to a surface profile, run across the well, at the top of figure V-26 (Lee and others, 1981).
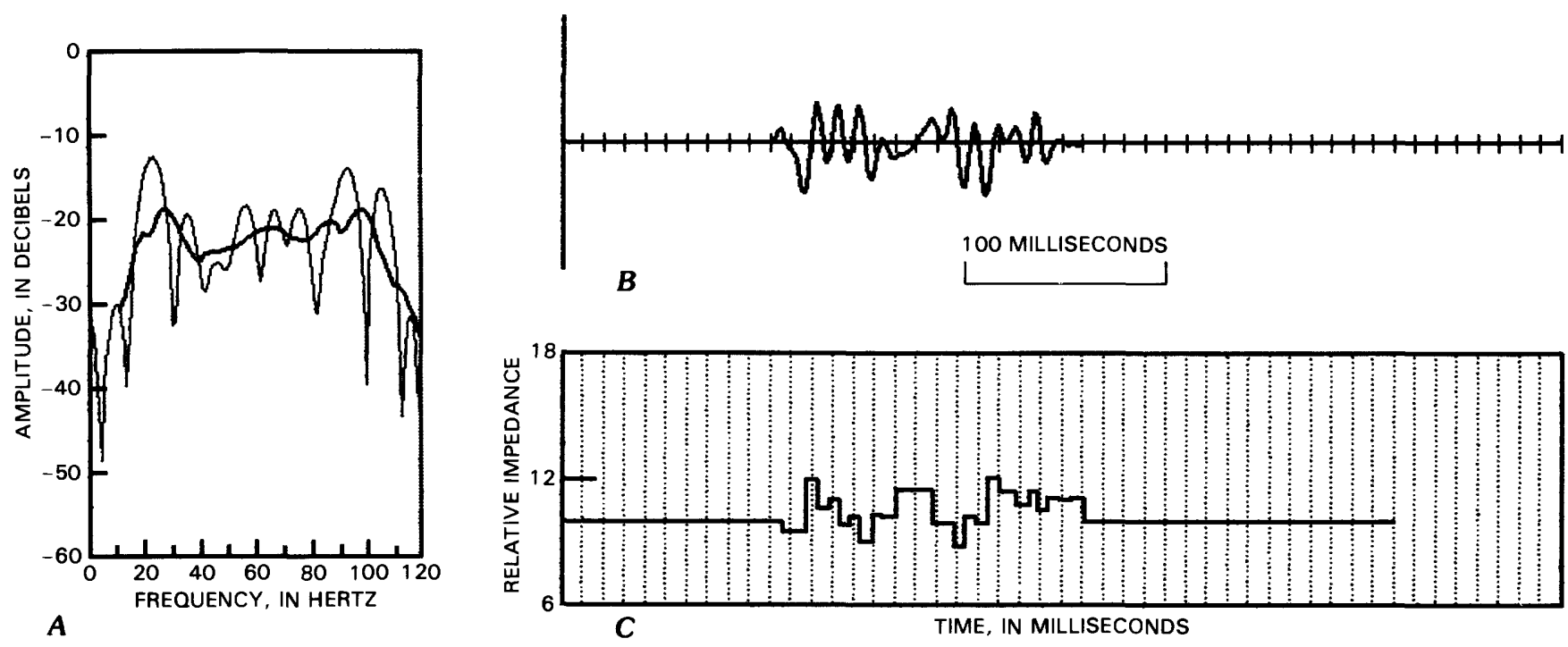

FIGURE V-29.-Calculation of the transfer functions of the Madison aquifer from the vertical seismic profile data at Pfister Fee No. 1 well, Wyoming. $A$, Amplitude spectrum of the transfer function; $B$, time-domain transfer function; $C$, estimated acoustic impedance $\log$. 



\author{
A SEISMIC-STRATIGRAPHIC INVESTIGATION OF THE MADISON AND ASSOCIATED \\ AQUIFERS-APPLICATION TO GROUND-WATER EXPLORATION, POWDER RIVER BASIN, \\ MONTANA-WYOMING
}

\title{
INTERPRETATIONS AND CONCLUSIONS
}

\author{
CHAPTER VI
}

\author{
By A. H. BÄLCH, M. W. LEE, and RoberT T. RYDER
}

\section{CONTENTS}

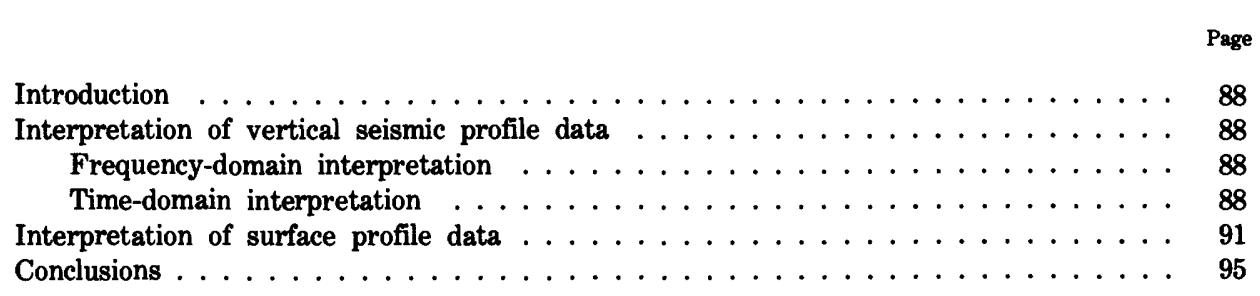

\section{ILLUSTRATIONS}

FIGURE VI-1. Calculated reflection transfer-function amplitude spectra for the Madison and associated aquifers based on six vertical seismic profile measurements . . . . . . . . . . . . . . . . . . . . . . . 89

VI-2. Estimated reflection transfer functions for the Madison and associated aquifers based on six vertical seismic profile

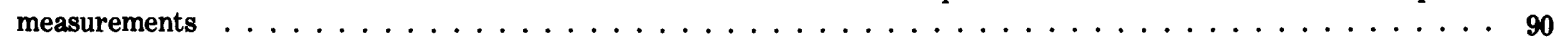

VI-3. Reflection strength plots of the six reflection transfer functions shown in figure VI-2 . . . . . . . . . . 92

VI-4. Estimated acoustic-impedance log plots for the Madison and associated aquifers derived from vertical seismic profile

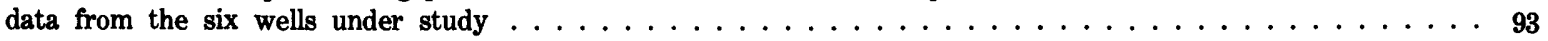

VI-5. Surface seismic profile across the Sam Gary Bell Creek Madison No. 1 well $\ldots \ldots \ldots$. . . . . . . . . . 94

VI-6. Surface seismic profile across the USGS Madison No. 2 well . . . . . . . . . . . . . . . . . . . . 94 


\section{INTRODUCTION}

The geologic investigation (chapter II) suggests that the highly productive zones in the Madison and associated aquifers range in thickness from 50 to $200 \mathrm{ft}$ and may extend laterally for tens of miles (pl. 1). Moreover, the zones of higher water productivity have a significantly lower interval velocity than do the adjacent zones of relatively low productivity ( $\mathrm{pl}$. 1), suggesting that these zones might be differentiated with seismic data. The inverse relation between water productivity and interval velocity in the Madison and associated aquifers is supported further by the plot of core-derived porosity values versus interval velocity (fig. II-2). Zones of low velocity or low acoustic impedance are not always accompanied by high permeability and high productivity, but if these zones in the Madison and associated aquifers can be located by seismic methods, the chances of finding large quantities of water are increased significantly. The influence of fracturing on aquifer performance at a given location-although probably significant-is difficult to document and thus has not been correlated with seismic data in this study.

In this chapter we will see if, and to what extent, the seismic response of the Madison and associated aquifers can detect increased water productivity as is suggested in chapter II. The VSP data are used in two ways. First, they measure the seismic response of specific zones in the Madison and associated aquifers and, second, they provide a high-confidence tie between lithologic logs from wells with reflected events on seismic lines run across the wells. Madison reflections from surface seismic lines across the USGS Madison No. 2 (Balch and others, 1981) and the Sam Gary Bell Creek Madison No. 1 (Miller and others, 1981) will be compared with the downhole recorded Madison reflections recorded in the corresponding VSP experiments.

\section{INTERPRETATION OF VERTICAL SEISMIC PROFILE DATA}

In the section on data processing (chapter IV), we discussed the transfer function in considerable detail. Our estimates of the seismic response of the Madison and associated aquifers and its relation to porosity are based on this transfer function concept. We used the upgoing and downgoing wave trains (observed near the top of the Madison) as input to the Kalman estimation process to calculate the transfer functions. These transfer functions embody all the relevant acoustic properties of the interval under investigation, at least as far as normally incident, plane compressional waves are concerned. We wish to use these transfer functions to distinguish porous, productive intervals of Madison and associated aquifers from tight, barren intervals. We analyzed the transfer functions in the frequency domain (using amplitude spectra) and in the time domain (using the transfer function itself and also an estimated impedance $\log$ derived from the transfer function).

\section{FREQUENCY-DOMAIN INTERPRETATION}

Figure VI-1 shows the Fourier amplitude spectra of the estimated reflection transfer functions for the Madison and associated aquifers in the six wells investigated. The three spectral plots on the bottom (USGS Madison No. 1, Sam Gary Bell Creek Madison No. 1, and Coronado Collins W-1) are from wells that have porous, productive intervals; the three plots at the top of the figure (USGS Madison No. 2, Bechtel ETSI No. $0-1$, and Pfister Fee No. 1) are from wells that have tight, barren intervals.

A general trend appears in these plots: we see a noticeable high-frequency fall off of the transfer function amplitude when the section is porous. Relatively little high-frequency loss takes place when the section is tight.

There are a number of possible causes for this observed phenomenon. Intrinsic attenuation, scattering, internal reflections, and fluid flow at boundaries (White and others, 1976) all could contribute to the loss of high-frequency reflections in the porous section. These observed frequency effects would be difficult to account for quantitatively, mainly because we lack good transmitted wave data in several wells.

We believe that the difference in reflection amplitude spectra is significant and reveals porosity, irrespective of the physical mechanism involved.

Although the nonporous stratigraphic sections are distinguishable from the porous sections on the basis of overall "flatness" of their reflection spectra, there are substantial individual variations in the spectra within both groups. This variation is to be expected, because none of the sections are identical and all measured signals are corrupted by a certain amount of noise. Because of the individual differences, the reflection spectrum has to be observed over more than two octaves in order to be classified properly. In a surface exploration situation, the measurement of the variation in reflection amplitude spectra would be pushing the state of the art close to the limit.

\section{TIME-DOMAIN INTERPRETATION}

As we stated earlier, we believe that water production comes from numerous porous zones within the 

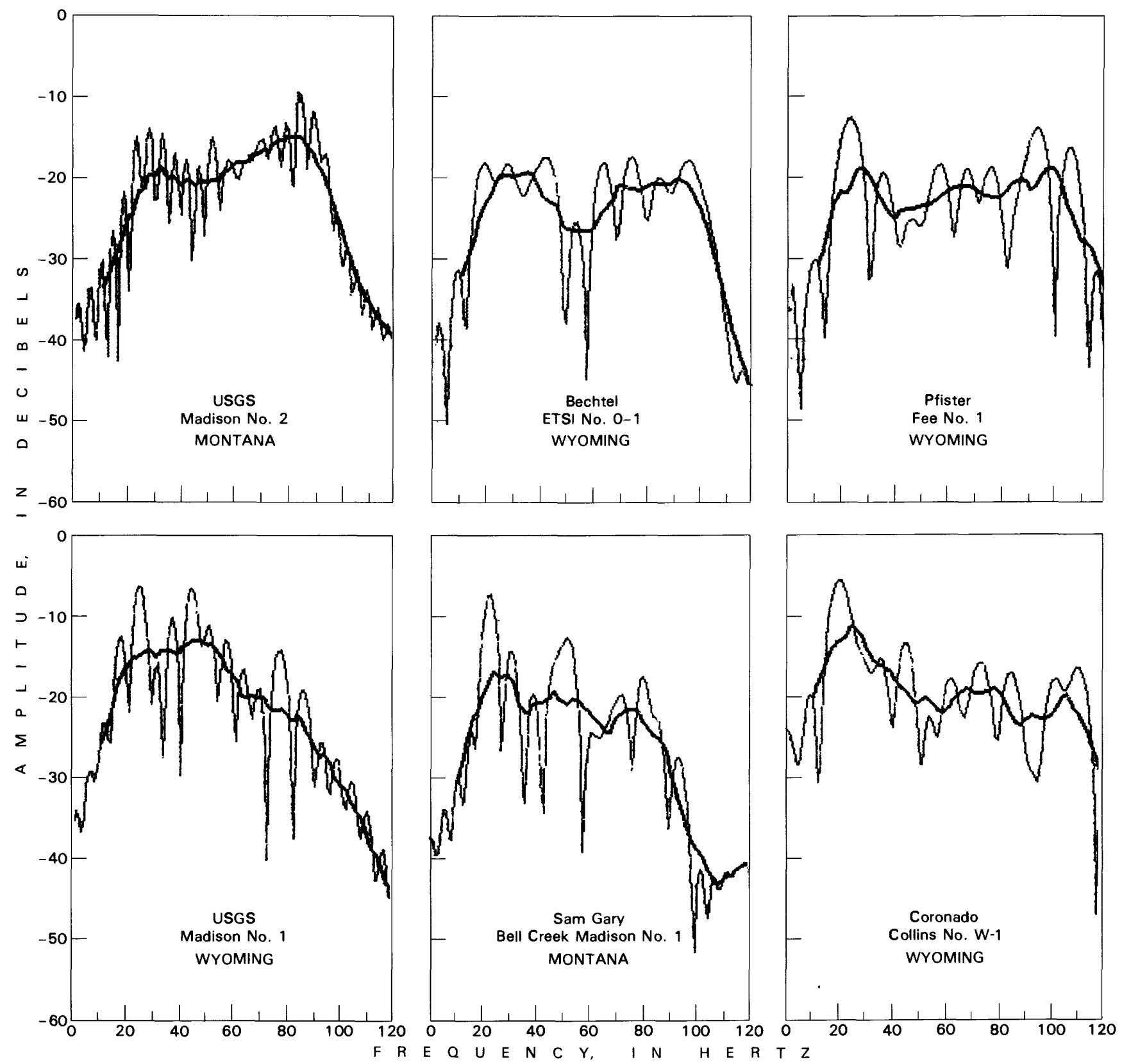

FIGURE VI-1.-Calculated reflection transfer function amplitude spectra for the Madison and associated aquifers based on six vertical seismic profile measurements. The top three spectra are from nonproductive intervals; the bottom three are from productive intervals. Note the high-frequency "fall-off" when the interval is water-productive. (See figure I-1 for location of wells and plate 1 for stratigraphic section in well.)

Madison and associated aquifers. When the spectral approach is used, the entire interval is analyzed as a unit. In the time-domain interpretation, we have treated the Madison and associated aquifers as a single unit and also have attempted to identify the individual porous zones. If the individual zones are thick enough, this approach has some validity because these zones often are identifiable on velocity and (or) density well logs.
There are internal reflections, a variety of lithologic sequences, band-limited signal, measurement noise, and computer processing "noise" to contend with. Therefore, to interpret every local variation in estimated acoustic impedance as a porosity zone is inappropriate. However, we shall see that major porous, productive zones do tend to show up on the estimated impedance logs. Most of our time-domain interpretations were 

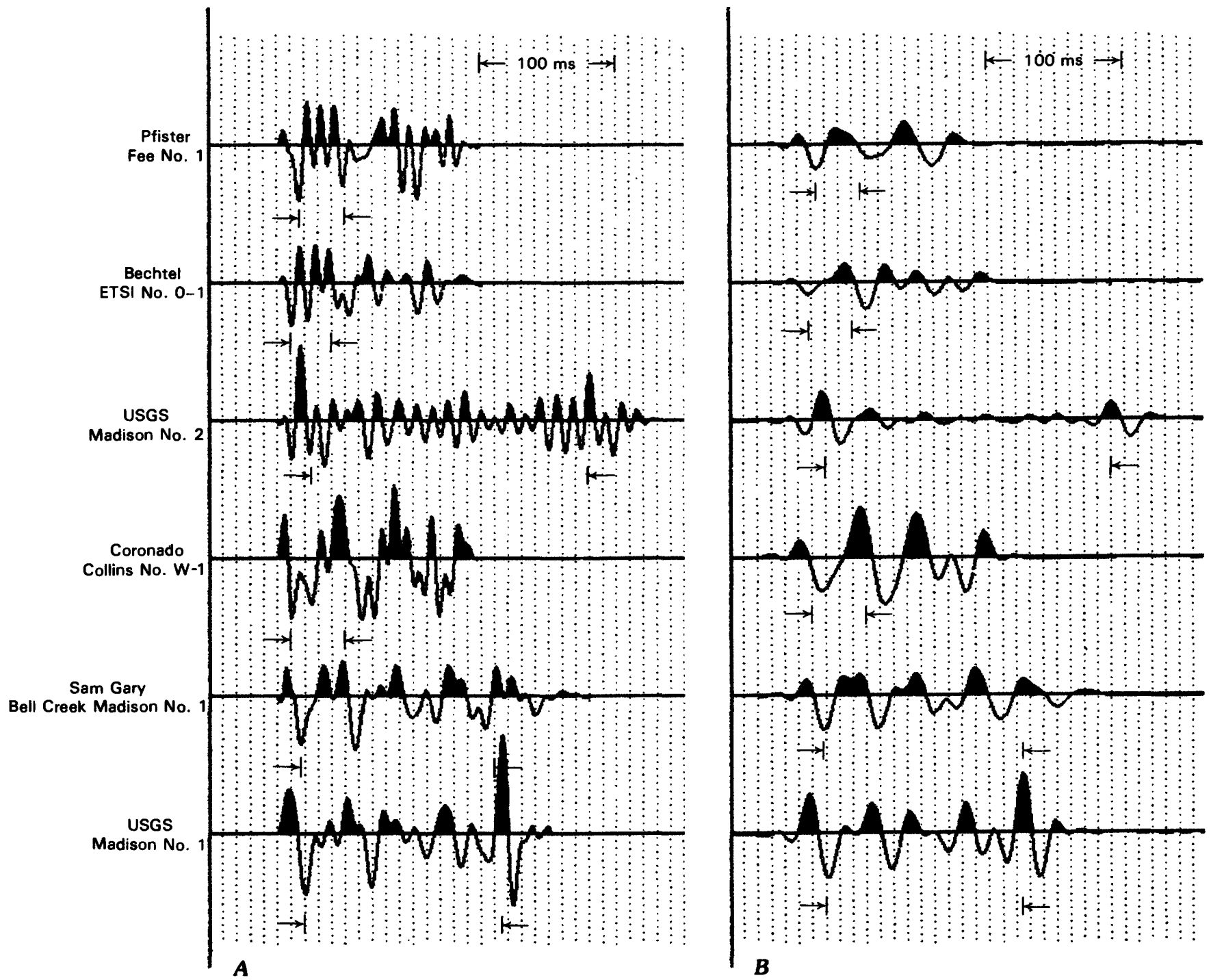

TIME, IN MILLISECONDS

FiguRE VI-2.-Estimated reflection transfer functions for the Madison and associated aquifers based on six vertical seismic profile measurements. The top three are from barren wells, the bottom three are from water-productive wells. The location of the Madison and associated aquifers in each well is defined by the interval between the arrows. $A$, Unfiltered version; $B$, band-pass filtered version of part $A(12-40 \mathrm{~Hz})$.

made in the northern study area because the interval of interest is only of $20-40 \mathrm{~ms}$ duration in the southern study area.

Figure VI-2A shows the original estimated transfer functions from the six wells, and figure VI-2B shows a band-pass filtered version of the data in figure VI$2 A$. In scaling these six plots, the input (downgoing wave amplitude) has been made unity. Therefore, the amplitudes of the transfer function plots (relative to each other) are meaningful. We can compare reflection amplitudes directly.
The reflection amplitudes from the porous, productive Madison and associated aquifers (USGS Madison No. 1, Sam Gary Bell Creek Madison No. 1, and Coronado Collins No. W-1) are quite noticeably higher than the corresponding amplitudes where the aquifer is barren (USGS Madison No. 2 and Bechtel ETSI No. $0-1)$. In addition, there are many more "events" on the transfer function of the productive Madison and associated aquifers. These events probably correspond to individual porous, productive zones. If water is produced from isolated zones within the productive Madison 
and associated aquifers, then a reasonable supposition is that these zones return additional events or reflections, and that they also may generate internal, multiple reflections as well. Both these phenomena could account for the large number of events observed on the transfer function associated with the productive sections. The events to which we refer stand out especially well in figure VI-2B, which has been low-pass filtered. In this lower frequency range, events subsequent to the top of the Madison are absent in the barren USGS Madison No. 2 well and are relatively low in amplitude in the barren Bechtel ETSI No. 0-1 well.

The Madison was not penetrated in the Pfister Fee No. 1 well, but its transfer function definitely puts it in the tight, barren class. We predict with considerable confidence that the Madison aquifer is nonproductive at that location.

The same information can be displayed on a "reflection strength" plot, using the Hilbert transform (Taner and others, 1979). The reflection strength versus time plots corresponding to figures VI-2A and VI-2B are shown in figures VI- $3 A$ and VI- $3 B$. The maximum reflected amplitudes from within the Madison and associated aquifers in the northern study area, based on the results shown in figures VI- $3 A$ and VI $-3 B$, are as follows:

\begin{tabular}{ccc}
\hline & \multicolumn{2}{c}{$\begin{array}{c}\text { Largest internal reflection amplitude; } \\
\text { frequency range, in Hertz(Hz) }\end{array}$} \\
\cline { 2 - 3 } & $10-80$ & $12-40$ \\
\hline USGS Madison No. 1 & & \\
$\quad$ (productive) . . . . . . . . & 0.14 & 0.11 \\
USGS Madison No. 2 (barren) & 0.08 & 0.02 \\
Sam Gary Bell Creek Madison & 0.13 & 0.08 \\
No. 1 (productive)....... & 0.13 \\
\hline
\end{tabular}

This analysis quantifies the correlation between reflection "strength" and the presence of porosity zones.

Another way to analyze the wave train returned from the top of the Madison is to estimate the acoustic impedance "log."

If we make several simplifying assumptions about the reflection process, we should be able to infer a layered sequence of rocks whose thickness, velocity, and density would produce the observed, reflected wave train. This sequence can be represented by a plot of acoustic impedance (density times velocity) versus two-way travel time (thickness divided by velocity). We call this plot an estimated impedance log, because it should correspond to a plot of acoustic impedance versus time (converted from depth) obtained from actual well logs measuring velocity and density.
The porosity zones that produce water usually can be identified on the observed acoustic impedance logs as zones of relatively low impedance. So we may be able to identify major producing horizons (if any) directly from the estimated impedance log.

The estimated impedance logs covering the Madison and associated aquifers for all six wells are shown in figure VI- 4 . The three tight barren Madison and associated aquifers are shown at the top, and the three productive Madison and associated aquifers are shown at the bottom. Known porosity zones are marked with a "P." The known zones of porosity correspond well with the impedance "low" zones. The correspondence is not perfect. Zones less than $10 \mathrm{~ms}$ thick are difficult to see, but the thicker, more significant porosity zones usually can be identified.

In summary, we have two types of time-domain displays and interpretations. The first type is a calculated transfer function and the second is a calculated (estimated) impedance log. Both displays appear to reveal productive porosity zones: the impedance logs do this directly and the transfer function appears to do this indirectly.

These are important results. If reflections measured directly at the interface reveal commercial water productivity, then possibly commercial water productivity can be detected from reflections measured at the ground surface. Conversely, if we could not distinguish between these two basic types of Madison and associated aquifers from the downhole measurement, the chances of doing this from the surface would be remote.

\section{INTERPRETATION OF SURFACE PROFILE DATA}

The seismic responses shown thus far are based on measurements made at or near the top of the Madison Group at depths of $3,000-8,000 \mathrm{ft}$. Let us now turn our attention to reflections from the Madison and associated aquifers made at the ground surface. We have run surface seismic profiles across five of the six wells that were investigated with vertical seismic profiles.

The reflections from the Madison and associated aquifers must be identified with a high level of confidence on the surface profile, which we have done by using the vertical seismic profile to tie the lithologic and well logs to the surface profile at each well location. Figure V-10 shows an example of how this identification is made. The center part of the figure is a processed vertical seismic profile from the Sam Gary Bell Creek Madison No. 1 well, Bell Creek field, Montana. Each horizontal trace represents the processed seismometer recording as a function of time at a given 


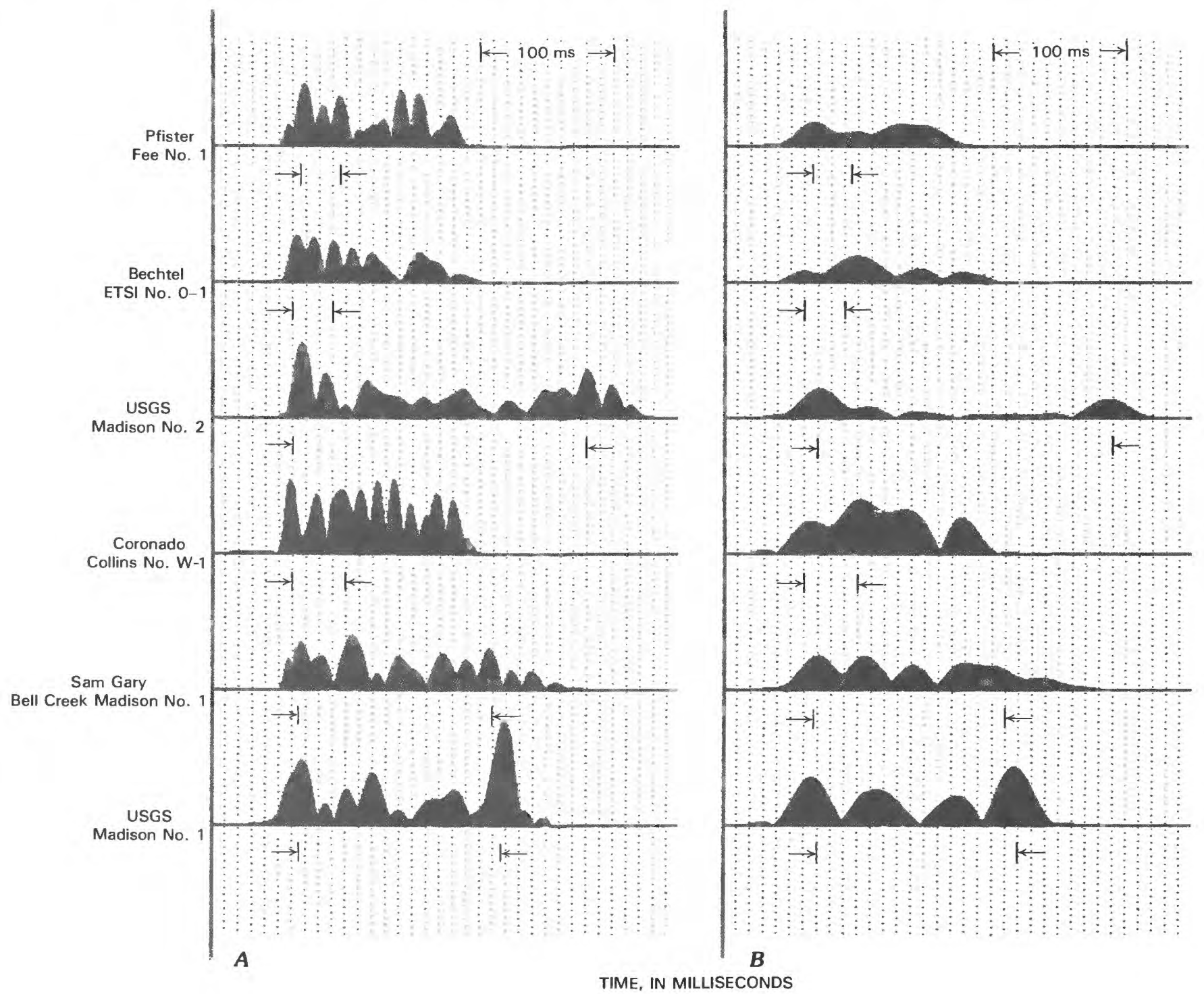

FiguRE VI-3.-Reflection strength plots of the six reflection transfer functions shown in figure VI-2. The location of the Madison and associated aquifers in each well is defined by the interval between the arrows. $A$, Unfiltered; $B$, with $12-40 \mathrm{~Hz}$ filter. Note the substantially greater reflection strength for the water-productive zones (lower three plots).

depth in the well. A lithologic log and a velocity log are shown on the left-hand side of the plot. A part of a surface seismic line, recorded near the top of the well, is plotted across the top of the figure. The first seismic events observable on the vertical seismic profile are the first arrivals from the source. The coherent events that appear to slant to the right in the figure represent reflections from various rock interfaces. The depth of origin of these reflections can be determined by tracking the events down to the level at which the reflection merges with the first arrival. The depth of origin of an event on the surface seismic profile can be determined by correlating the event to the top of the vertical seismic profile, and then tracking it down to its level of origin as just described. In this manner we have identified the reflection from the top of the Madison as the event just preceding the 1.5-s mark on the surface data plots.

The entire 15-mi surface seismic profile that runs across the Sam Gary Bell Creek Madison No. 1 well is shown in figure VI-5. The top part of the vertical seismic profile is spliced into the section at the appropriate place. The reflection from the top of the Madison already has been identified on the vertical seismic profile by tracking to level of origin. We can now extend this well tie to the rest of the cross section by horizon- 


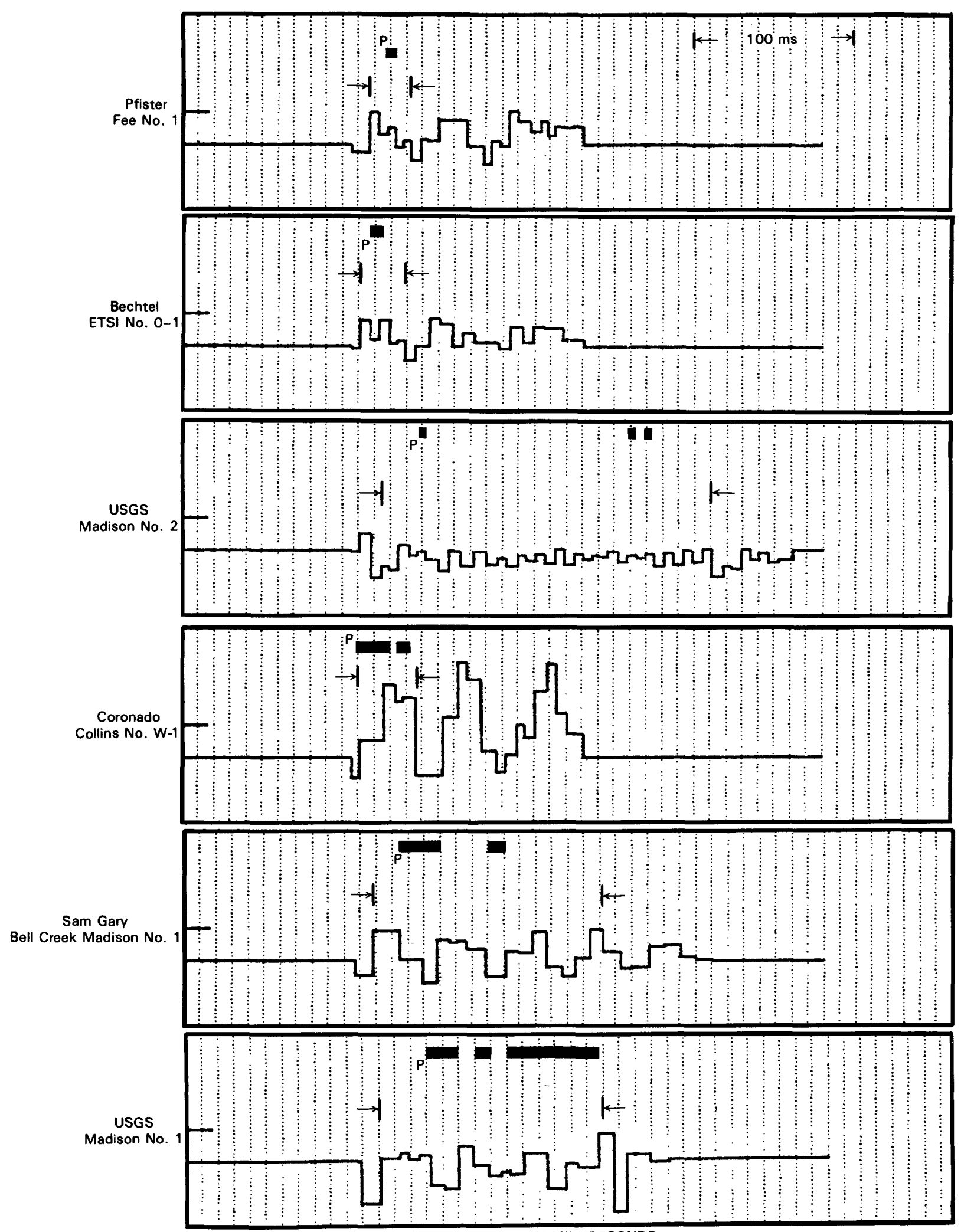

TIME, IN MILLISECONDS

FIGURE VI-4.-Estimated acoustic-impedance log plots for the Madison and associated aquifers derived from vertical seismic profile data from the six wells under study. The location of the Madison and associated aquifers in each well is defined by the interval between the arrows. Location of known porosity zones, $P$, are indicated by solid bars. 

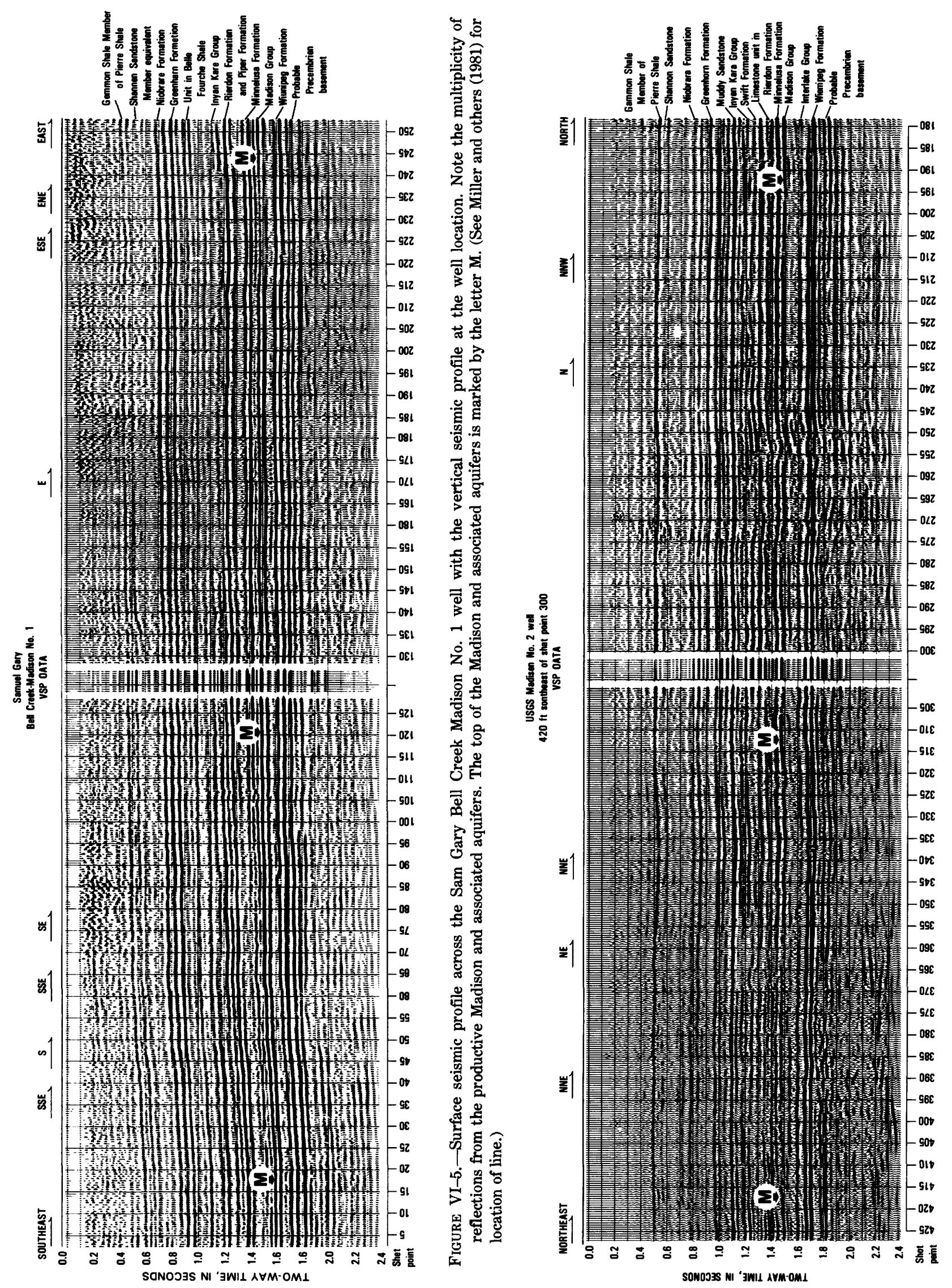

ह

ธิ

苚

잉

응

突

总

密

ฆ ํㅗㅀ

苍

茟

8

ซ

옹

항

5

랭

ล

है

号

สำ

远

巳

志

\%

N

宅

5

:

藏

प

路

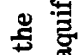

:

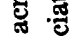

这

范

ह

. :

.

蛋

की

$\varphi$

5 。

国 
tal correlation. The Madison top is indicated with an "M" in this figure. At the Sam Gary Bell Creek Madison No. 1 well, the Madison aquifer flows at $250 \mathrm{gal} /$ min, and the nearby Sam Gary Bell Creek Madison No. 2 well flows at about $900 \mathrm{gal} / \mathrm{min}$.

Figure VI-6 shows a similar surface seismic profile and vertical seismic profile that runs across the USGS Madison No. 2 well about $30 \mathrm{mi}$ northeast of the Bell Creek field. The Madison top is indicated with an "M." The Madison and associated aquifers are essentially tight, dry, and barren at the USGS Madison No. 2.

The transfer functions indicated that interbed reflections should appear where porous, water-productive zones occur in the Madison and associated aquifers (fig. VI-2). In comparing figure VI-5 with figure VI-6, we do indeed see an additional reflection below the top of the Madison event in figure VI-5, presumably from an interbed.

This result strongly suggests that commercially significant aquifers may be detected by surface reflections. The surface profile is relatively low frequency (peaked at about $30 \mathrm{~Hz}$ ). We believe that the interbed reflections, owing to porous zones in Madison and associated aquifers, would be enhanced considerably if higher frequencies had been used.

\section{CONGLUSIONS}

We have described part of our stratigraphic seismic investigation of the Madison and associated aquifers in the eastern Powder River Basin of Wyoming and Montana. We used vertical seismic profiles to measure certain acoustic properties of the stratigraphic interval. We developed new field techniques and new processing procedures to determine acoustic differences between porous-productive and tight-barren end members of the Madison and associated aquifers.
We have measured the acoustic properties of the Madison and associated aquifers in six wells. We have observed the following:

1. A fall-off of high-frequency reflections when the section is productive relative to nonproductive sections,

2. A substantial increase in the amplitude and number of reflections from the section when it is productive relative to the nonproductive sections, and

3. That calculated impedance "logs" based on seismic reflections from the interval tend to reveal zones of low impedance that correspond to known zones of productivity.

To identify porosity zones from surface reflection data is considerably more difficult because the reflections are corrupted by their trip to the surface, the reflections are lower in frequency and narrower in frequency band width due to earth attenuation, and considerable uncertainty exists about the input, or downward-traveling, seismic waveform. Nevertheless, in the two surface seismic examples described here, a significant additional interbed reflection can be observed where the Madison and associated aquifers are commercially water productive.

In the northern study area, we conclude that porousproductive Madison and associated aquifers can be differentiated from tight-nonproductive ones on the basis of acoustic differences as observed from reflected wave trains in the exploration seismic frequency range. The transfer function amplitudes derived from the VSP data suggest that similar results, although more subtle, might be obtainable with surface seismic profiles in the southern study area. However, the absence of a surface seismic profile over a porous, productive Madison aquifer in the southern study area precludes us from providing supporting evidence. 



\title{
A SEISMIC-STRATIGRAPHIC INVESTIGATION OF THE MADISON AND ASSOCIATED AQUIFERS-APPLICATION TO GROUND-WATER EXPLORATION, POWDER RIVER BASIN, MONTANA-WYOMING
}

\section{REFERENCES CITED}

\author{
CHAPTER VII
}

Adams, J. E., and Rhodes, M. L., 1960, Dolomitization by seepage refluxion: American Association of Petroleum Geologists Bulletin, v. 44, no. 12, p. 1912-1920.

Anderson, K. E., and Kelly, J. E., 1976, Exploration for ground water in the Madison Limestone, Niobrara County, Wyoming: Wyoming Geological Association 28th Annual Field Conference Guidebook, p. 277-281.

Andrichuk, J. M., 1955, Mississippian Madison Group stratigraphy and sedimentation in Wyoming and southern Montana: American Association of Petroleum Geologists Bulletin, v. 39, p. 2170-2210.

Balch, A. H., Lee, M. W., Miller, J. J., and Ryder, R. T., 1981, Processed and interpreted U.S. Geological Survey seismic reflection profile and vertical seismic profile, Powder River and Custer Counties, Montana: U.S. Geological Survey Oil and Gas Investigations Chart OC-108.

Blankennagel, R. K., 1967, Hydraulic testing techniques of deep drill holes at Pahute Mesa, Nevada test site: U.S. Geological Survey Open-File Report, Interagency Report, Special Studies 1-I, $50 \mathrm{p}$.

Blankennagel, R. K., Miller, W. R., Brown, D. L., and Cushing, E. M., 1977, Report on preliminary data for Madison Limestone test well No. $1, \mathrm{NE}^{1 / 4} \mathrm{SE}^{1 / 4}$ sec. 15 , T. 57 N., R. 65 W., Crook County, Wyoming: U.S. Geological Survey Open-File Report 77$164,97 \mathrm{p}$.

Brobst, D. A., and Epstein, J. B., 1963, Geology of the Fanny Peak Quadrangle, Wyoming-South Dakota, Chapter I, in Geology and uranium deposits of the southern Black Hills: U.S. Geological Survey Bulletin 1063, p. 323-377.

Brown, D. L., 1978, Wrench-style deformational patterns associated with a meridional stress axis recognized in Paleozoic rocks in parts of Montana, South Dakota, and Wyoming, in 1978 Williston basin symposium: Montana Geological Society 24th Annual Conference, p. $17-31$.

Brown, D. L., Blankennagel, R. K., Busby, J. F., and Lee, R. W., 1978, Preliminary data for Madison Limestone test well No. 2, $\mathrm{SE}^{1 / 4} \mathrm{SE} 1 / 4$ sec. 18 , T. 1 N., R. 54 E., Custer County, Montana: U.S. Geological Survey Open-File Report 77-863, 134 p.

Brown, D. L., Blankennagel, R. K., MacCary, L. M., and Peterson, J. A., 1982, Correlation of paleostructure and sediment deposition in the Madison Limestone and associated rocks in parts of Montana, North Dakota, South Dakota, Wyoming, and Nebraska: U.S. Geological Survey Open-File Report 82-906, 83 p.

Craig, L. C., 1972, Mississippian System, in Mallory, W. W., ed., Geologic atlas of the Rocky Mountain region: Rocky Mountain Association of Geologists, p. 100-110.

Embree, P., Burg, J. P., and Backus, M. M., 1963, Wide band velocity filtering-The pie slice process: Geophysics, v. 28, p. 948-974.
Folk, R. L., and Land, L. S., $1975, \mathrm{Mg} / \mathrm{Ca}$ ratio and salinity; two controls over crystallization of dolomite: American Association of Petroleum Geologists Bulletin, v. 59, no. 1, p. 60-68.

Foster, M. R., Sengbush, R. L., and Watson, R. J., 1964, Suboptimum filter systems for seismic data processing: Geophysical Prospecting, v. 12, p. 193-181.

Foster, N. H., 1972, Ordovician System, in Mallory, W. W., ed., Geologic atlas of the Rocky Mountain region: Rocky Mountain Association of Geologists, p. 76-85.

Fuller, J.G.C.M., 1961, Ordovician and contiguous formations in North Dakota, South Dakota, Montana, and adjoining areas of Canada and United States: American Association of Petroleum Geologists Bulletin, v. 45, no. 8, p. 1334-1363.

Fuller, J.G.C.M., and Porter, J. W., 1969, Evaporite formations with petroleum reservoirs in Devonian and Mississippian of Alberta, Saskatchewan, and North Dakota: American Association of $\mathrm{Pe}-$ troleum Geologists Bulletin, v. 53, no. 4, p. 909-926.

Gries, J. P., and Mickelson, J. C., 1964, Mississippian carbonate rocks of western South Dakota and adjoining areas, in Williston basin symposium, 3d International, Regina, Saskatchewan, 1964, Proceedings: Billings, Mont., Billings Geological Society, p. 109118.

Hanshaw, B. B., Back, W., and Deike, R. G., 1971, A geochemical hypothesis for dolomitization by groundwater: Economic Geology, v. 66 , p. $710-724$.

Hardage, R. A., 1981, An examination of tube wave noise in vertical seismic profiling data: Geophysics, v. 46, no. 6, p. 892-903.

Hodson, W. G., 1974, Records of water wells, springs, oil- and gastest holes, and chemical analyses of water for the Madison Limestone and equivalent rocks in the Powder River Basin and adjacent areas, northeastern Wyoming: Wyoming State Engineer (in cooperation with the U.S. Geological Survey), $26 \mathrm{p}$.

Huang, C. F., and Hunter, J. A. M., 1981a, The correlation of "tube wave" events with open fractures in fluid-filled boreholes, in Current research, part. A: Geological Survey of Canada Paper 81-1A, p. $161-376$.

1981b, A seismic "tube wave" method for in-situ estimation of rock fracture permeability in boreholes: Society of Exploration Geophysicists 51st International Annual Meeting, Los Angeles, Calif., Technical Papers, v. 1, p. 23-46.

Illing, L. V., Wells, A. J., and Taylor, J. C. M., 1965, Penecontemporary dolomite in the Persian Gulf, in Pray, L. C., and Murray, R. C., eds., Dolomitization and limestone diagenesis-A symposium: Society of Economic Paleontologists and Mineralogists Special Publication 13, p. 89-111. 
Illing, L. V., Wood, G. V., and Fuller, J.G.C.M., 1967, Reservoir rocks and stratigraphic traps in non-reef carbonates, in Origin of oil, geology and geophysics-World Petroleum Congress, 7th, Mexico, 1967, Proceedings, v. 2: London, Elsevier, p. 487-499.

Jenkins, M. A., and McCoy, M. R., 1958, Cambro-Mississippian correlations in the eastern Powder River Basin, Wyoming and Montana: Wyoming Geological Association 13th Annual Field Conference Guidebook, p. 31-35.

Kinsman, D. J. J., 1969, Modes of formation, sedimentary associations, and diagnostic features of shallow water and supratidal evaporites: American Association of Petroleum Geologists Bulletin, v. 53 , no. 4 , p. $830-840$.

Kolm, J. A., and Louden, R. O., 1979a, Cores, mechanical logs tied to Red River exploration, production: Oil and Gas Journal, v. 77 , no. 28 , p. 169-178.

1979b, Exploration success depends upon finding Ordovician Red River structure: Oil and Gas Journal, v. 77, no. 29, p. 89-94. $-1979 c$, " $\mathrm{B}$ " and " $\mathrm{C}$ " cycles contain most hydrocarbon reserves in Williston: Oil and Gas Journal, v. 77, no. 30, p. 77-79.

Lee, M. W., Miller, J. J., Ryder, R. T., and Balch, A. H., 1981, Processed and interpreted U.S. Geological Survey seismic reflection profile and vertical seismic profiles, Niobrara County, Wyoming: U.S. Geological Survey Oil and Gas Investigations Chart 0C-114.

Love, J. D., Henbest, L. G., and Denson, N. M., 1953, Stratigraphy and paleontology of Paleozoic rocks, Hartville area, eastern Wyoming: U.S. Geological Survey Oil and Gas Investigations Chart OC $-44,2$ sheets.

MacCary, L. M., Cushing, E. M., and Brown, D. L., 1983, Potentially favorable areas for large-yield wells in the Red River Formation and Madison Limestone in parts of Montana, North Dakota, South Dakota, and Wyoming: U.S. Geological Survey Professional Paper 1273-E, 13 p.

Mallory, W. W., 1979, Central Rocky Mountains and northern Colorado Plateau region, Chapter M, in Craig, L. C., and Connor, C. W., coordinators, Introduction and regional analysis of the Mississippian system, pt. I of Paleotectonic investigations of the Mississippian system in the United States: U.S. Geological Survey Professional Paper 1010, p. 209-219.

Maughan, E. K., 1963, Mississippian rocks in the Laramie Range, Wyoming, and adjacent areas: U.S. Geological Survey Professional Paper 475-C, p. C23-C27.

Maughan, E. K., and Roberts, A. E., 1967, Big Snowy and Amsden Groups and the Mississippian-Pennsylvanian boundary in Montana: U.S. Geological Survey Professional Paper 554-B, 27 p.

McCaleb, J. A., and Wayhan, D. A., 1969, Geologic reservoir analysis, Mississippian Madison Formation, Elk Basin field, Wyoming-Montana: American Association of Petroleum Geologists Bulletin, v. 53 , no. 10, p. 2094-2113.

Medith, J. S., 1969, Stochastic optimal linear estimation and control: New York, McGraw-Hill, 394 p.

Mendel, J. M., and Kormylo, John, 1978, Single-channel white-noise estimations for deconvolution: Geophysics, v. 43, p. 102-124.

Miller, J. J., Ryder, R. T., Balch, A. H., and Lee, M. W., 1981, Processed and interpreted U.S. Geological Survey seismic reflection profile and vertical seismic profile, Powder River and Carter Counties, Montana: U.S. Geological Survey Oil and Gas Investigations Chart OC-110.

Murray, R. C., 1960, Origin of porosity in carbonate rocks: Journal of Sedimentary Petrology, v. 30, no. 1, p. 59-84.

Peterson, J. A., 1981, Stratigraphy and sedimentary facies of the Madison Limestone and associated rocks in parts of Montana, North Dakota, South Dakota, Wyoming, and Nebraska: U.S. Geological Survey Open-File Report 81-642, 83 p.
Roberts, A. E., 1966, Stratigraphy of Madison Group near Livingston, Montana, and discussion of karst and solution-breccia features: U.S. Geological Survey Professional Paper 526-B, p. B1-B23.

1979, Northern Rocky Mountains and adjacent plains region, Chapter $\mathrm{N}$ in Craig, L. C., and Connors, C. W., coordinators, Introduction and regional analysis of the Mississippian system, pt. I of Paleotectonic investigations of the Mississippian system in the United States: U.S. Geological Survey Professional Paper 1010, p. 221-247.

Roehl, P. O., 1967, Stoney Mountain (Ordovician) and Interlake (Silurian) facies analogs of recent low-energy marine and subaerial carbonates, Bahamas: American Association of Petroleum Geologists Bulletin, v. 51, no. 10, p. 1979-2032.

Rose, P. R., 1976, Mississippian carbonate shelf margins, western United States: U.S. Geological Survey Journal of Research, v. 4, no. 4, p. 449-466.

Ryder, R. T., Balch, A. H., Lee, M. W., and Miller, J. J., 1981, Processed and interpreted U.S. Geological Survey seismic reflection profile and vertical seismic profile, Carter County, Montana and Crook County, Wyoming: U.S. Geological Survey Oil and Gas Investigations Chart OC-115.

Sandberg, C. A., and Mapel, W. J., 1967 [1968], Devonian of the northern Rocky Mountains and plains, in Oswald, D. H., ed., International symposium on the Devonian System, Calgary, Alberta, Sept. 1967 [Proceedings] v. 1: Calgary, Alberta, Alberta Society of Petroleurn Geologists, p. 843-877.

Sando, W. J., 1967, Madison Limestone (Mississippian), Wind River, Washakie, and Owl Creek Mountains, Wyoming: American Association of Petroleum Geologists Bulletin, v. 51, no. 4, p. 529557.

1974, Ancient solution phenomena in the Madison Limestone (Mississippian) of north-central Wyoming: U.S. Geological Survey Journal of Research, v. 2, no. 2, p. 133-141.

1975, Diastem factor in Mississippian rocks of the northern Rocky Mountains: Geology, v. 3, no. 11, p. 657-660.

1976a, Mississippian history of the northern Rocky Mountains region: U.S. Geological Survey Journal of Research, v. 4, no. 3, p. 317-338.

1976b, Madison Limestone (Devonian and Mississippian), east flank of Bighorn Mountains, Wyoming: Wyoming Geological Association 28th Annual Field Conference Guidebook, p. 45-52.

1979, Lower part of the Carboniferous in Lageson, D. R., Maughan, E. K., and Sando, W. J., eds., The Mississippian and Pennsylvanian (Carboniferous) systems in the United StatesWyoming, chap. $U$ of the Mississippian and Pennsylvanian (Carboniferous) systems in the United States: U.S. Geological Survey Professional Paper 1110, p. U2-U16.

Schlumberger Limited, 1972, Log interpretation, v. 1-Principles: New York, Schlumberger, $112 \mathrm{p}$.

Sengbush, R. L., and Foster, M. R., 1968, Optimum multi-channel velocity filters: Geophysics, v. 33, p. 11-35.

Sheldon, R. P., and Carter, M. D., 1979, Williston basin region, Chapter O, in Craig, L. C., and Connors, C. W., coordinators, Introduction and regional analysis of the Mississippian system, pt. I of Paleotectonic investigations of the Mississippian system in the United States: U.S. Geological Survey Professional Paper 1010, p. 249-271.

Shinn, E. A., Ginsburg, R. N., and Lloyd, R. M., 1965, Recent supra-tidal dolomite from Andres Island, Bahamas, in Pray, L. C., and Murray, R. C., eds., Dolomitization and limestone diagenesis-A symposium: Society of Economic Paleontologists and Mineralogists Special Publication 13, p. 112-123.

Stanton, R. J., Jr., 1966, The solution brecciation process: Geological Society of America Bulletin, v. 77, no. 8, p. 843-848. 
Swenson, F. A., Miller, W. R., Hodson, W. G., and Visher, F. N., 1976, Maps showing configuration and thickness, and potentiometric surface and water quality in the Madison Group, Powder River Basin, Wyoming and Montana: U.S. Geological Survey Miscellaneous Investigations Series, Map I-847-C.

Taner, M. T., Koehler, F., and Sheriff, R. E., 1979, Complex seismic trace analysis: Geophysics, v. 44, no. 6, p. 1041-1063.

Tullos, F. N., and Reed, A. C., 1969, Seismic attenuation of Gulf Coast sediments: Geophysics, v. 34, no. 4, p. 516-528.

U.S. Geological Survey, 1975, Plan of study of the hydrology of the Madison Limestone and associated rocks in parts of Montana, Nebraska, North Dakota, South Dakota, and Wyoming: U.S. Geological Survey Open-File Report 75-631, 35 p.
White, J. E., Mikhaylova, N. G., and Lyakhovitskiy, F. M., 1976, Low-frequency seismic waves in fluid-saturated layered rocks: Physics of the Solid Earth (English edition) v. 11, p. 654-659.

Wuenschell, P. C., 1976, The vertical array in reflection seismology: Geophysies, v. 41, no. 2, p. 219-232.

Wyllie, M. R. J., Gregory, A. R., and Gardner, G. H. F., 1956, Elastic wave velocities in heterogeneous and porous media: Geophysics, v. 21, no. 1, p. 41-70.

-1958, An experimental investigation of factors affecting elastic wave velocities in porous media: Geophysics, v. 23 , no. 3 , p. $459-493$. 